Portland State University

PDXScholar

Winter 3-21-2016

\title{
Exploring Transnational Economic, Social, and Political Participation of Mexican Immigrants in Oregon
}

Anabel López Salinas

Portland State University

Follow this and additional works at: https://pdxscholar.library.pdx.edu/open_access_etds

Part of the Public Affairs Commons, Public Policy Commons, and the Social Policy Commons Let us know how access to this document benefits you.

\section{Recommended Citation}

López Salinas, Anabel, "Exploring Transnational Economic, Social, and Political Participation of Mexican Immigrants in Oregon" (2016). Dissertations and Theses. Paper 2703.

https://doi.org/10.15760/etd.2699

This Dissertation is brought to you for free and open access. It has been accepted for inclusion in Dissertations and Theses by an authorized administrator of PDXScholar. Please contact us if we can make this document more accessible: pdxscholar@pdx.edu. 
Exploring Transnational Economic, Social, and Political Participation of Mexican

Immigrants in Oregon

by

Anabel López Salinas

A dissertation submitted in partial fulfillment of the requirements for the degree of

\author{
Doctor of Philosophy \\ in \\ Public Affairs and Policy
}

\author{
Dissertation Committee: \\ John Corbett, Chair \\ Mary King \\ Alex Stepick \\ Craig Shinn \\ Eva Nunez
}

Portland State University

2016 


\begin{abstract}
Using a mixed methods approach and expanding on the literature on immigrants' transnational civic engagement, this research explores the paths and barriers to Mexican immigrant civic, economic, political, and social engagement in both immigrants' communities of origin in Mexico and communities of residence in Oregon, a relatively new destination for Mexican immigrants. The majority of the adult Mexican population only arrived to the state of Oregon over the last 15 years. Today Latinos represent the largest racial-ethnic minority, twelve percent of the state population, with Mexicans making up 90 percent of this Latino population. Most of the Mexican immigrants in Oregon come from rural communities in Mexico, have an indigenous background, experience low levels and literacy, and up to 90 percent of the adult Mexican population is undocumented (King et al., 2011). This research modifies Paasche and Fangen's (2012) framework to better capture the civic engagement of Mexican immigrants in Oregon who lack legal status in the U.S. and who come from an indigenous background.

The conventional wisdom is that immigrants are more engaged in their new communities the longer they have lived there, the more educated and well paid they are, and the better they speak English. Yet the majority of Mexican migrants in Oregon lack these attributes as well as legal status, yet still appear to be strongly engaged in both Mexico and in the United States. Immigrants organize to pursue economic, political, and socio-cultural transnational goals in Mexico and in the U.S. Politicians, researchers, and activists in both Mexico and the United States have noted the growing importance of these migrant groups as bridges between the two nations (Rivera Salgado et al., 2005, p. 3). Transnational organizations provide immigrants with the opportunity to be civically
\end{abstract}


involved with the development of their communities of origin, and at the same time also participate in social, economic and political issues in the United States. Civic participation by Mexican immigrants is of importance to Oregon's future because the majority of these immigrants have settled permanently in the United States with their families and have and will continue to affect public policy that will shape Oregon's future. 


\section{Dedication}

I would like to dedicate this study to my mother, Marina Salinas, family, friends and the Mexican immigrants that work hard every day to support their families across the U.S.-Mexican border, especially those that I have met in Oregon who have opened their home to me. 


\section{Acknowledgments}

I would like to acknowledge my dedicated dissertation committee, Dr. John Corbett, Dr. Mary King, Dr. Alex Stepick, Dr. Craig Shinn, and Dr. Eva Nunez, for assisting me in the lengthy process of writing my dissertation. I would also like to thank the professors and staff at the Hatfield School of Government for their support in this endeavor. Additionally, I would also like to give a heartfelt thanks to the Mexican nationals whom I interviewed and who, with open hearts, provided me with the critical stories that enriched my work. Rachel Buckley, Angel Contreras, and Anindita Mukerjee, thank you very much for reading my work and providing feedback.

I express my sincere gratitude to the Mexican National Council of Science and Technology (CONACYT) and the Ryoichi Sasakawa Young Leaders Fellowship Fund (SYLFF) Program sponsored by the Tokyo Foundation, institutions that provided me with funding to carry out this research project. Any opinions, findings, and conclusions, or recommendations expressed in this research are those of the author and do not necessarily reflect the views of any of these organizations. I would also like to thank the Center for U.S.-Mexican Studies at UC San Diego for hosting me as a visiting scholar in 2015. As the UC closest to the border, this fellowship opportunity allowed me to fully explore the strong and vibrant tradition of scholarship on Mexico-U.S. relations. 


\section{Table of Contents}

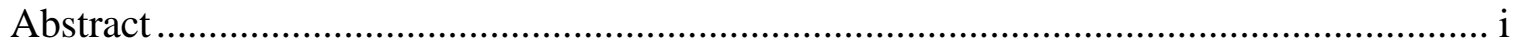

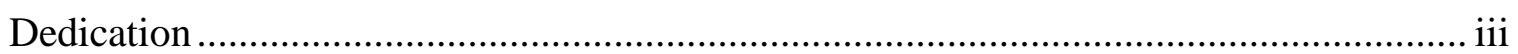

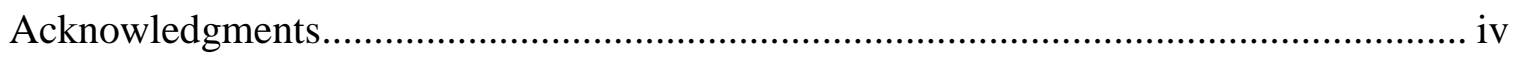

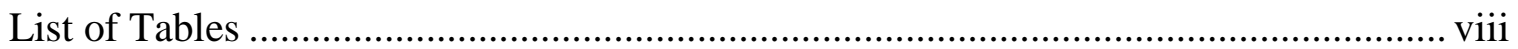

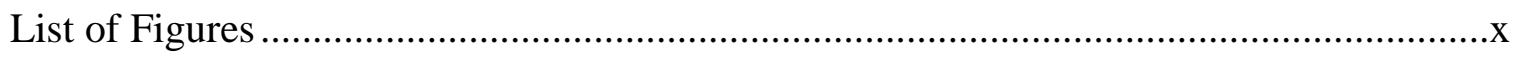

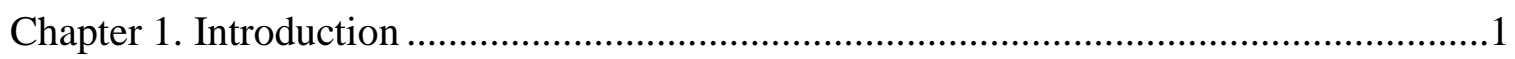

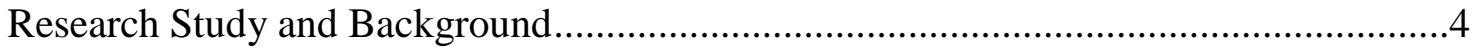

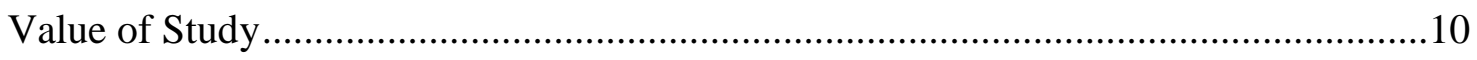

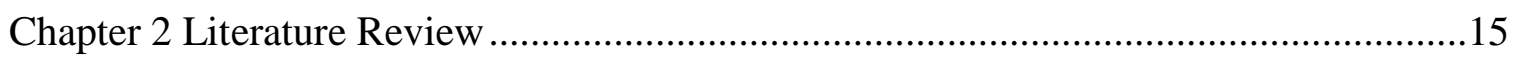

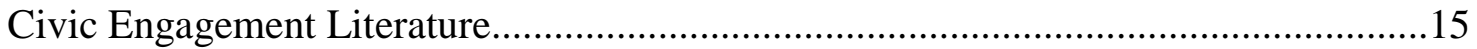

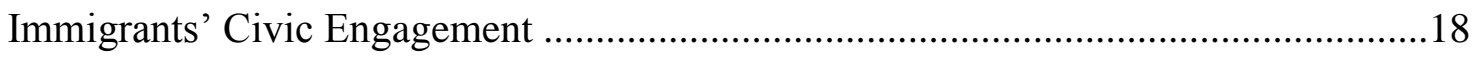

Mexican immigrants' transnational civic participation.........................................21

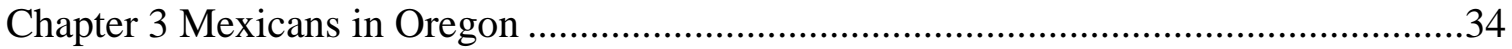

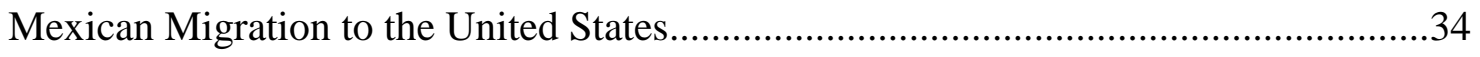

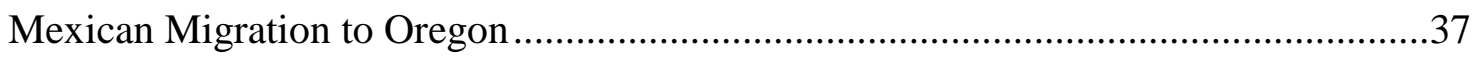

Current Context of Mexican migration in Oregon .......................................................40

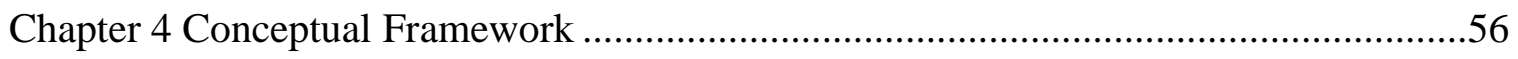

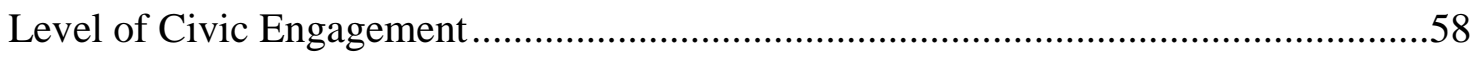

Independent Variables/Contextual Factors ...........................................................64

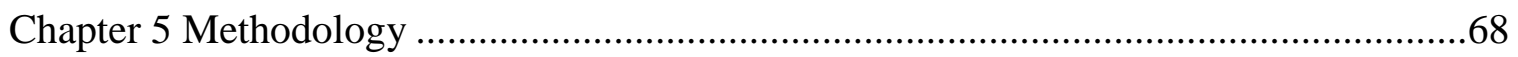

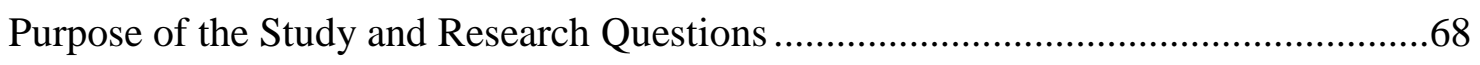

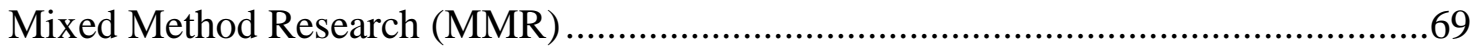

Triangulation Design in Mixed Methods Research.................................................70

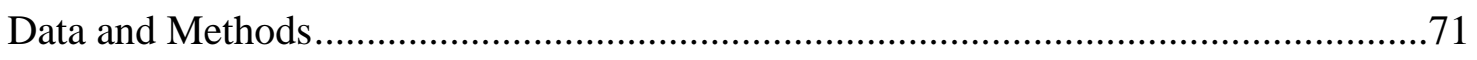

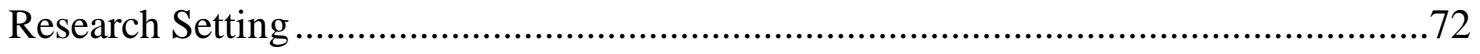

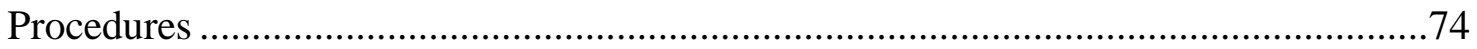

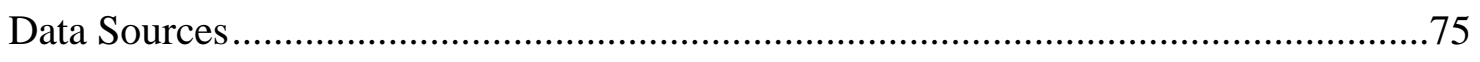

Subject recruitment and sampling design ............................................... 75

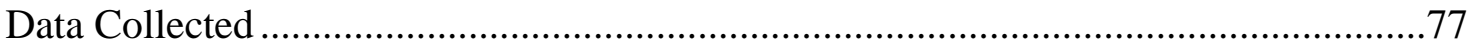




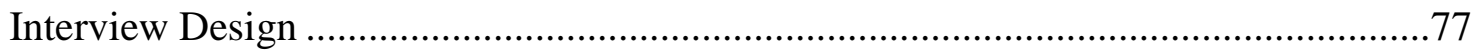

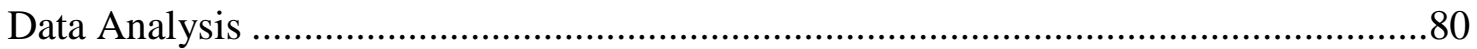

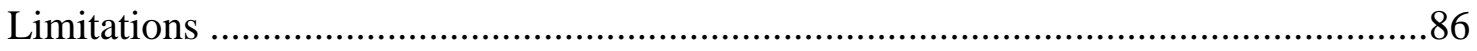

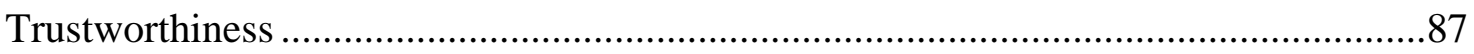

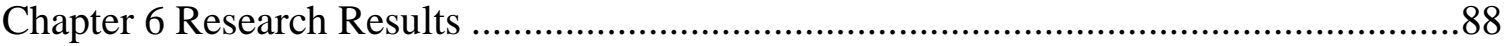

Mexican Immigrants' Transnational Civic Engagement .......................................89

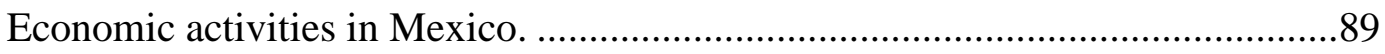

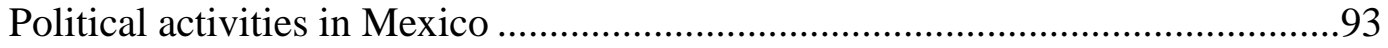

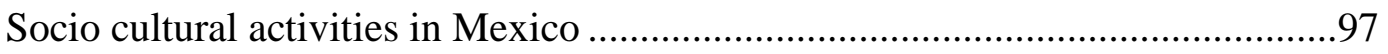

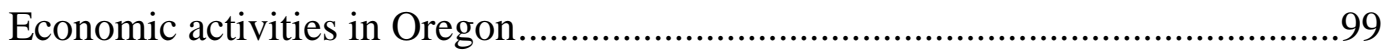

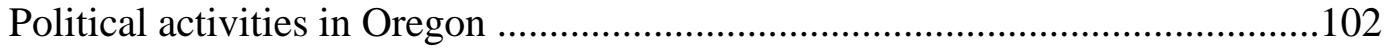

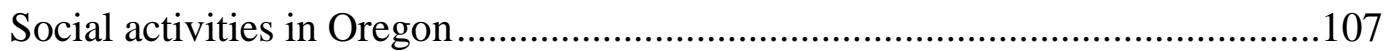

Changes in Mexican Immigrants' Civic Engagement with Communities of Origin and

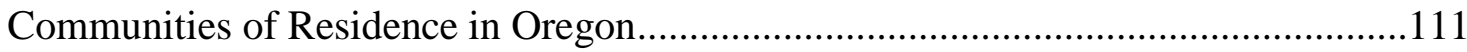

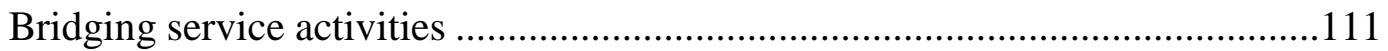

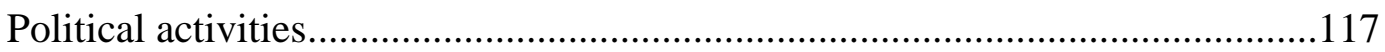

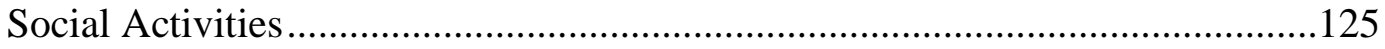

Paths and Barriers to Mexican Immigrant Civic Engagement in Oregon ...................135

Paths to Mexican immigrants' civic engagement .........................................135

Barriers to Mexican immigrants' civic engagement........................................156

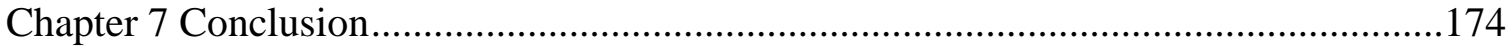

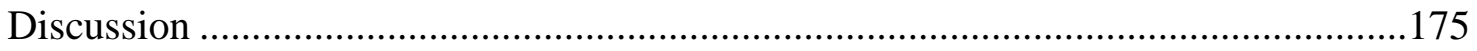

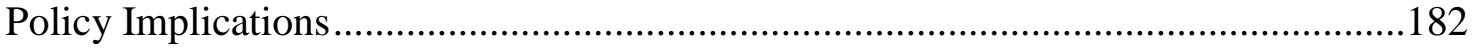

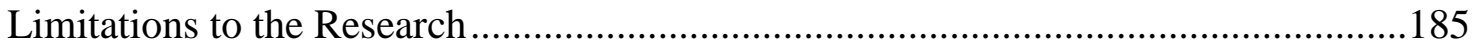

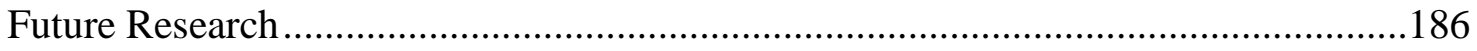

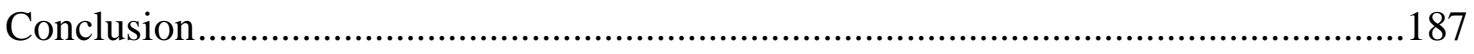

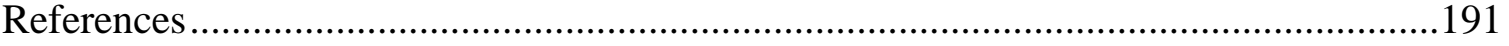

Appendix A. English and Spanish Study Flyers .................................................206

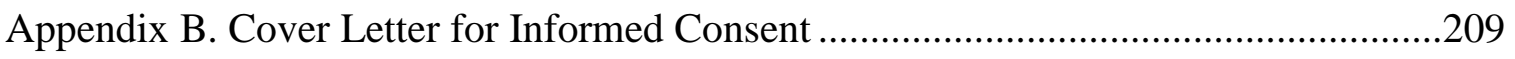

Appendix C. Interview Guide for a Semi-Structured Interview ................................212 
Appendix D. Gift Card Receipts (English and Spanish).........................................232 


\section{List of Tables}

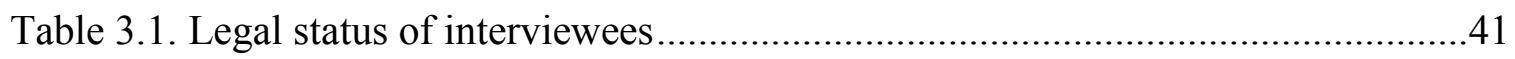

Table 3.2. Hispanic Population in the Portland and Salem metropolitan areas................43

Table 3.3. Demographic characteristics of the sample ................................................47

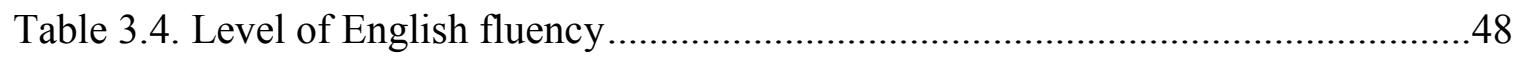

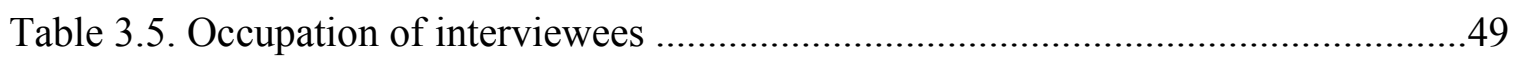

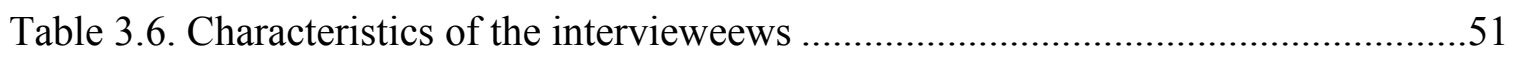

Table 4.1. Overview of transnational activities ...........................................................57

Table 4.2. Overview of immigrants' transnational activities in their communities of

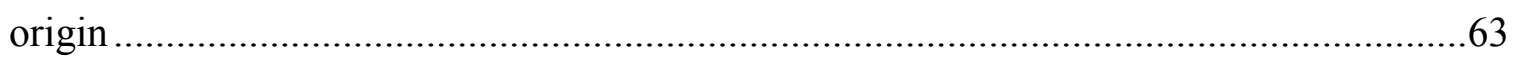

Table 4.3. Overview of immigrants' civic engagement in Oregon.................................63

Table 5.1. Triangulation design procedures (QUAN +QUAL) ...................................75

Table 5.2. Changes in bridging service, political and social activities done in Mexico and

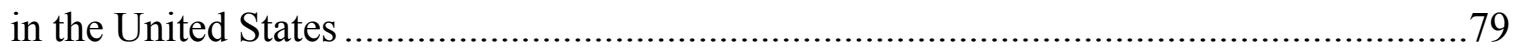

Table 6.1. Economic engagement in Mexico.........................................................92

Table 6.2. Political engagement in Mexico .................................................................95

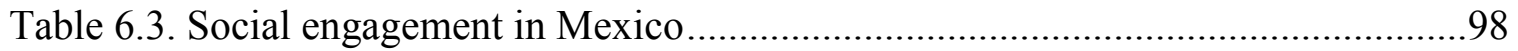

Table 6.4. Economic engagement in the United States ............................................101

Table 6.5. Percentage of formal political activities .................................................. 102

Table 6.6. Political engagement in the United States .................................................107

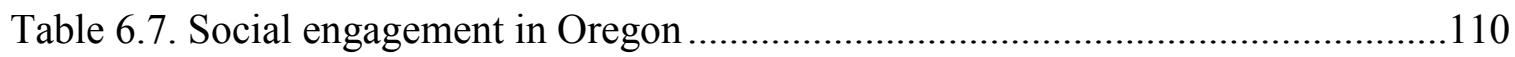

Table 6.8. Bridging service, political, and social activities in Mexico and in the United

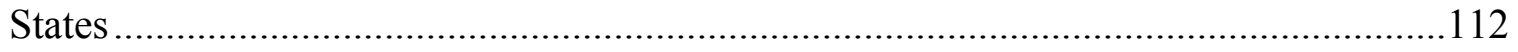

Table 6.9. Bridging Service activities in Mexico and in the United States summary

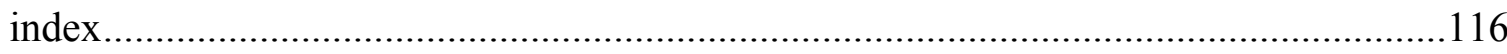

Table 6.10. Political activities in Mexico and in the United States summary index .......123

Table 6.11. Social activities in Mexico and in the United States summary index...........132

Table 6.12. Frequencies of key organizations in interview discussions (50

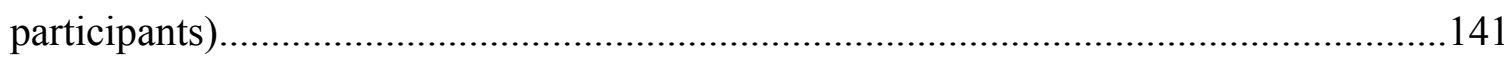

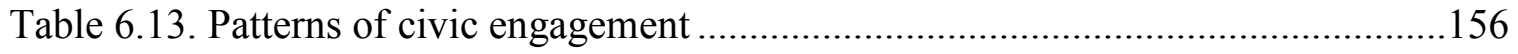

viii 
Table 6.14. Participant's discussion about mistrust in Latino organizations......

Table 6.15. Participants' discussion around cultural differences as a barrier to civic engagement ...

Table 6.16. Why do people not participate? 


\section{List of Figures}

Figure 3.1 General representation of Mexican migration to Oregon.............................. 38

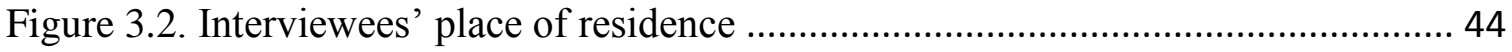

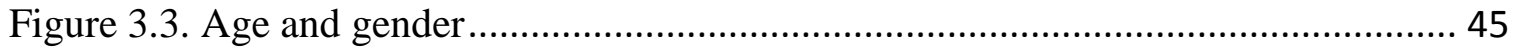

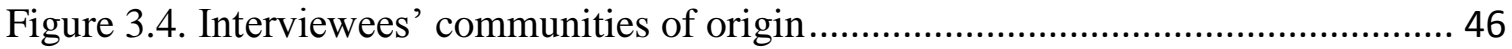

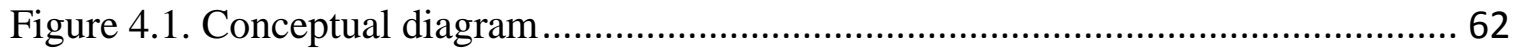

Figure 5.1. The triangulation design in MMR (QUAN+QUAL) ................................. 71

Figure 5.2. Steps in analyses of thematic networks based on Attride-Stirling, (2001).... 82

Figure 5.3. Example of thematic network analysis, based on Attride-Stirling (2001) ..... 85

Figure 6.1. How often do you send money to Mexico? .............................................. 90

Figure 6.2. Do you know for what the money is used? ............................................ 91

Figure 6.3. How do you get news related to Mexico? ................................................ 94

Figure 6.4. Public policy issue you feel is the most important in Mexico...................... 96

Figure 6.5. How do you make yourself aware of news and current affairs in the US? .. 105

Figure 6.6. What is your most frequently used mode of communication? .................... 106

Figure 6.7. Demonstration outside the Mexican Consulate in Portland for the visit of

some of the parents of the Ayotzinapa missing students......................................... 118

Figure 6.8. A Mexican flag with the sign of the 43 missing students was raised outside of the Mexican Consulate in Portland ....................................................................... 120

Figure 6.9. Margarita (right) after her soccer team won a tournament, on the grounds of Pacific University in Forest Grove, Oregon

Figure 6.10. 2015 San Mateo Tonuchi (Oaxaca) community celebration in Mulino,

Oregon

Figure 6.11. What community means to you?

Figure 6.12. Have you participated through an organization to solve a problem in Mexico? 146

Figure 6.13. Do you know what is the most serious problem in your community of residence? 
Figure 6.14. If you could vote, for which Party would you vote? ............................... 153

Figure 6.15. Barriers to civic engagement most mentioned by the interviewees ........... 160 


\section{Chapter 1. Introduction}

The conventional wisdom is that immigrants are more engaged in their new communities the longer they have lived there, the more educated and well paid they are, and the better they speak English. Yet the majority of Mexican migrants in Oregon lack these attributes as well as legal status, yet still appear to be strongly engaged in both Mexico and in the United States.

Within the last two decades the Mexican immigrant population in Oregon has increased considerably (King et al., 2011; Bussel, 2008). In Oregon, approximately 12 percent of the population is Latino, with Mexicans making up the largest immigrant population in the state (U.S. Census Bureau, 2010; King et al., 2011). The majority of these Mexican immigrants have settled in Oregon within the last twenty years, making Oregon a new destination for this population (King et al., 2011). The majority of Mexicans residing in Oregon share similar demographic characteristics: they are from rural areas, have a low level of literacy, have limited knowledge of English, and usually lack legal status (Warren, 2009; King et al., 2011). Some research suggests that immigrants with these characteristics will not integrate civically in their communities of residence (Huntington, 2004; Portes \& Rumbaut, 2006). However, Mexican immigrants in Oregon come from communities with unusually strong traditions of participatory local self-government. In Oregon, as in other places across the country, Mexican immigrants now run organizations, hold political positions, hold leadership positions, attend marches, volunteer in schools and organizations, and send money to help improve the economic development of their communities of origin (Bada, Fox, Selee, \& Sánchez Álvarez, 2006; Bussel, 2008; Reyes Morales \& Gijón Cruz, 2011; Stephen, 2007). In fact, for 
some immigrants, civic engagement in their community of origin is, in fact, a predictor of civic engagement in their communities of residence (Fox, 2005; Chacon, 2010; Stephen, 2007).

Immigrants who are engaged with their communities of origin tend to also be engaged with their communities of residence in the United States (Escamilla-Hamm, 2009; Fox and Bada, 2011). This form of engagement is known as transnationalism and includes "a set of social expectations, cultural values, and patterns of human interaction shaped by more than one social, economic, and political system" (Glick Schiller, 2003). Transnational immigrants" civic engagement is “delimited to economic, political, and sociocultural" activities (Portes, Guarnizo, \& Landold 1999, p. 219) and "complements" their civic participation in their communities of residence (Fox \& Bada, 2011; Rivera Salgado, Bada, \& Escala-Rabadan, 2005).

The purpose of this research was to understand Mexican immigrants' civic engagement, including the relationship between civic participation of Mexican immigrants within their communities of origin and their communities of residence in Oregon. In order to understand Mexican immigrants' transnational engagement, the central question explored was:

Do Mexican immigrants, who are usually undocumented, have limited education and English speaking skills, and come from rural and indigenous communities participate in the transnational civic life of the Portland and Salem metropolitan areas? If so, how?

In order to answer the above research question, this project addresses the following sub-questions: 
1. How civically engaged are Mexican immigrants in Oregon? Does civic engagement differ by gender, age, indigenous background, economic and legal status, length of time in the U.S., English fluency, and education level?

2. Does the engagement of immigrants with their home communities detract from engagement in Oregon, or enhance it? Has this relationship changed over time?

3. What are the issues with which participants are most often engaged in their communities of residence?

4. What are the barriers that most deter participants from civic engagement in their communities of residence?

5. Which organizations do this group of immigrants work with on civic issues? How?

Gaining insight into this research question is significant for both academics and policy makers because by analyzing the relationship between immigrants' civic participation within their communities of origin and their communities of residence, immigrants' civic engagement can be increased in new destinations such as Oregon. The present study provides an overview of the relevant policy issues for immigrants. This information offers academics a new perspective on immigrants' transnationalism and civic empowerment in Oregon, a state little studied in this field. Similarly, this research provides interested political actors a deeper understanding of immigrants' organizational and policy priorities. These data will help in the design of policies and strategies informed by an increased understanding of Oregon's diverse communities. For the purposes of this project, the researcher conducted a semi-structured interview with a 
diverse pool of 50 Mexican immigrants residing in the metropolitan areas of Portland and Salem, Oregon.

\section{Research Study and Background}

The Unites States of America, as the self-proclaimed "nation of immigrants," attracts immigrants from all over the world. Abu-Laban and Garber (2005) state that the decision to migrate to the United States is made by each person individually and is followed by consequences in his or her country of origin as well as in the United States.

Scholars differ on how immigrants are seen and received by the host country (Perlmann, 2005; Massey \& Sánchez, 2010). For instance, in the United States, some people believe that immigrants take advantage of food stamps, medical care, or unemployment benefits, services that are supposed to be used only by U.S. citizens and U.S. permanent residents (Marrow, 2011, p. 15; Massey \& Sanchez, 2010, p. 24; Sanchez, 1997, p. 1020). People who are against the growth of the immigrant population are afraid that American values may be threatened by immigrants, who maintain their language, culture, and values instead of integrating into American society (Sanchez, 1997). In particular, Massey (2010) cites Americans such as Samuel P. Huntington (2004), who coined the phrase "the Hispanic Challenge" to describe the perception that Latinos are not assimilating, and that their arrival may threaten American culture. Latinos in general, but Mexicans more specifically, are frequently seen as the group whose integration into U.S. Society elicits the most significant concern (Huntington, 2004).

Unlike past immigrant groups, Mexicans and other Latinos have not assimilated into mainstream U.S. culture, forming instead their own political and linguistic enclaves from Los Angeles to Miami - and rejecting the Anglo- 
Protestant values that built the American dream... The United States ignores this challenge at its peril (Huntington in Massey 2010, p. 249).

Prior to the $20^{\text {th }}$ century, with few and costly means of transportation, immigrants wishing to go their home country faced a real challenge to go overseas. Once pre-20 ${ }^{\text {th }}$ century immigrants were in the United States, maintaining strong ties with their homeland proved difficult (Durand \& Massey, 2003). Currently, migration is enhanced by significantly reduced travel costs, faster means of communication, and active governmental intervention from home countries: these changes encourage more fluid movement between countries of origin and host countries (Durand \& Massey, 2003, p. 14). People who have migrated to the United States are more likely to be in the U.S., but also remain civically active in their home country. Telecommunications and travel are now relatively inexpensive; $\ldots$ and this allows immigrants who desire an ongoing civic and political connection to their communities or countries of origin to establish or maintain these ties" (DeSipio, 2011, p. 1205). For some immigrants, being civically engaged in their communities of residence also implies that they are more likely to remain active in their communities of origin (DeSipio, 2011; Levitt \& Waters, 2002; Portes, 2003).

DeSipio (2011) argues that suspicions that immigrants will not become civically active in their communities of residence are "unsubstantiated" (p. 1205) because the majority of these immigrants are involved in cultural events but not necessarily in political or civic events in their home countries. DeSipio (2011) also states that immigrants who are involved in transnational activity are more involved in U.S. civic and 
political activities than those immigrants who do not maintain civic ties to their home countries.

Today, Mexican immigrants participate in and engage with various aspects of the life in their communities across the United States (Massey \& Sánchez, 2010). These forms of participation in Oregon include activism in policy debates such as current immigration reform, lobbying for driving permits and tuition equity, and volunteering at their children's schools. In addition, while living in the United States, Mexican immigrants participate in social, political, and economic relations with U.S. citizens as part of their daily lives.

\section{Mexicans in the United States}

The estimated Hispanic population in the USA in 2012 was 53 million, making people of Latino origin the largest minority (American Community Survey, 2005-2009). Two thirds of that Latino population are from Mexico, making them the largest Hispanic group in the U.S. (Brown \& Lopez, 2013). People of Mexican descent in the United States account for approximately 34 million people, including 12 million Mexican-born immigrants (Ortiz Gabriel, 2012). Migration to the U.S. from Mexico is the largest migration stream in world history (Massey \& Sana, 2003). Around 10 percent of the Mexican born population lives in the United States (Passell \& Cohn, 2011): the majority live in states with a longer migration tradition than Oregon, especially those who were living in what was Mexican territory before the Mexican-American War (1846-1848) (Durand, Massey \& Capoferro, 2005). Until 1990, approximately half of the Mexican immigrants of "productive ages" were concentrated in only a few cities in the Unites States, primarily in California and Texas (Card \& Lewis, 2005). Mexicans from states 
with a "long migration tradition" such as Zacatecas, Michoacán, and Guanajuato (Consejo Nacional de Población, 2010, p. 23) have a lengthier history of U.S. settlement. More recently, migrants from the states of Oaxaca, Puebla, Distrito Federal, Guerrero, Hidalgo, Estado de Mexico, Queretaro, and Tlaxcala have joined this migration (Durand \& Massey, 2003; Terrazas, 2010).

In the last few years Mexicans living in the United States can be found settled all over the country (D'aubeterre, Rivermar, Buznego \& Pérez, 2007), including in the state of Oregon. In Oregon, approximately 12\% of residents are Latino, with Mexicans making up the largest immigrant population in the State (U.S. Census Bureau, 2010; King et al., 2011). Stephen, Mendoza and Magaña (2008) have argued that Mexicans started coming in larger numbers to Oregon as a consequence "of the upheaval caused by the Mexican revolution" in the early 1900s. However, significant Mexican migration to Oregon is a "relatively recent phenomenon" (King et al., 2011). According to Bussel (2008), "over the last two decades, the face of Oregon has changed dramatically with the arrival" of a significant number of immigrants, many of them Mexican. Seventy to eighty percent of the adult Mexican population in Oregon likely arrived during the last two decades and up to 90 percent lack legal status (King, et. al., 2011).

Approximately $70 \%$ of the Mexicans living in Oregon reside in the upper northwest quadrant of the state (King et al., 2011). The metropolitan areas of Salem and Portland are the most populous in the State and contain the largest Mexican population in Oregon. $21.9 \%$ out of 390,738 people in the Salem metropolitan area are Latinos. The Salem metropolitan area is more agricultural than Portland. Generations of Mexicans have settled in the area since the 1940's, when Mexicans first started coming to the state 
for agricultural work as a result of the "Bracero Program"1 (Gamboa, 1990; Gamboa \& Buan, 1995; Gonzales-Berry \& Mendoza, 2010). A small proportion of these immigrants have resided in Oregon since mid-century. However, the majority of Mexican immigrants arrived in Oregon over the last two decades, especially those who settled in the Portland metropolitan area. In the Portland metropolitan area $11.7 \%$ out of $1,789,580$ people are Latino (Population Research Center, 2010). It was not until the 1980's that Mexicans started settling permanently in their new communities of residence in Oregon (Alcalá Tobón, 2013; Gonzales-Berry \& Mendoza, 2010).

\section{Why Mexicans Residing in Oregon?}

The Pew Hispanic Center states that Mexican migrants to the United States have increasingly come "from states further south in the country" (Kochhar, 2005, p. 29). In the last few decades, approximately 30 percent of the Mexicans who have migrated to the United States came from these "new sending states" (Kochhar, 2005, p. 29). Oregon is now the home of Mexican immigrants from new sending states such as Oaxaca, Guerrero, Puebla, and Veracruz, along with people from long-standing and high density migration states - Michoacán, Guanajuato, and Jalisco (Alvarado Juarez, 2008). For some Mexican immigrants in Oregon, regardless of their socio demographic characteristics - from rural and indigenous communities, undocumented, with low levels of literary and low levels of English -understanding the challenge of being civically engaged in the U.S. depends upon civic engagement with their country of origin (Fox \& Bada, 2011).

\footnotetext{
${ }^{1}$ A bilateral program that allowed primarily working age men from rural communities to work in the U.S. temporarily with documents during World War II worker shortages in the U.S. (Rivera Sánchez, 2011). This program created the primary characteristics of Mexican immigrants who worked in the United States after the program ended: young and single men (or at least not with a wife in the U.S.), from rural communities, mainly working in agricultural jobs (Durand \& Massey, 2003).
} 
Many of the Mexican immigrants in Oregon come from rural indigenous communities where helping each other in the town is important and institutionalized in a system often referred to as "guelaguetza" (Stephen, 2007). These community members have developed a high potential for civic engagement. As scholars have suggested, the level of immigrants' participation in their communities of origin is a determinant of civic participation in the United States. Both types of participation seem to be complementary (DeSipio, 2011; Levitt \& Waters, 2002; Portes, 2003). In fact, some researchers and scholars have claimed that immigrants' engagement in Hometown Associations (HTAs) may be seen as "bridges between the two nations" (Rivera-Salgado, Bada, \& EscalaRabadan, 2005, p. 129).

The existence of organizations that support immigrants' rights has shaped Mexicans' civic involvement in their home communities as well, in both Mexico and in the U.S. These organizations have given Mexican immigrants the ability to be visible and engaged with their communities of residence (DeSipio, 2011; Escamilla-Hamm, 2009; Fox, 2010; Rivera-Salgado, Gaspar-Bada \& Escala-Rabadan, 2005). Mexicans in Oregon are civically engaged in a variety of ways: they attend churches, volunteer at their children's schools, organize events, donate money for political campaigns, vote, attend and organize forums and marches in concert with pro-immigrant organizations, and attend protests and marches against the Mexican government's unfair/unjust policies.

However, it is important to highlight that the majority of the Mexicans living in Oregon come from rural communities, have low literacy levels, and that $95 \%$ of them are undocumented (King et al., 2011; Warren, 2009). The presence of Mexican immigrants in Oregon with these demographic characteristics create a challenging research and 
policy scenario. Because there are few venues where public officials and academics interact spontaneously with members of immigrant groups, there are limited opportunities to develop contextual knowledge of group dynamics which foster interaction and policy. Officials must act based on limited information and few communication channels to improve or convey knowledge.

The purpose of this study is to understand the civic engagement processes of Mexicans residing in the metropolitan areas of Portland and Salem, Oregon. This research offers public officials and academics a more systematic understanding of how civic engagement is understood and practiced in local Mexican populations, thereby enhancing the quality of community interactions.

\section{Value of Study}

Contemporary studies of immigrant civic participation in American society offer different perspectives on how immigrants are seen and received by their host country (Perlmann, 2005; Hing, 2004). Some people believe immigrants are and want to be part of the civic life of the community where they live (Massey, 2010). Some Americans fear that American values may be threatened by immigrants who remain immersed in their native language, culture, and values, rather than fully integrating into American society (Sanchez, 1997, p. 1020; Marrow, 2011, p. 15; Massey \& Sanchez, 2010, p. 24). Scholars advance the idea that immigrants will not civically integrate with their communities of residence if they have strong ties to their communities of origin, are from rural communities, have a low literacy levels, have limited knowledge of English, and are undocumented (Huntington, 2004; Portes \& Rumbaut, 2006). This position assumes that immigrants are in the U.S. for the short term, are primarily looking for economic gain, 
and have no interest in the civic and political life of the country to which they migrate (Massey \& Sanchez, 2010; Sanchez, 1997).

Contrary to such assertions, DeSipio (2011) argues that fears that immigrants and their descendants will not integrate into American society are "unsubstantiated" (p. 1205) because the majority of them are involved in cultural events, but not necessarily in political or civic events, in their home countries. Immigrants who are involved in transnational activity are more involved in U.S. civic and political activities than those immigrants who do not have any ties to their home communities (DeSipio, 2011). Transnational immigrants' civic engagement is "economic, political, and sociocultural" (Portes, Guarnizo, \& Landold 1999), and for some immigrants it "complements" their local civic engagement in their communities of residence. Maintaining civic and cultural ties to the home country, and therefore having a transnational identity, increases the likelihood that immigrants will be active in local political or civic organizations in the U.S. (Fox \& Bada, 2011; Rivera Salgado et al., 2005). When public leaders assume immigrants will not participate in community life, they deprive themselves of opportunities to foster collaboration and integration. This may result in losing the opportunity to incorporate Latino voices and interests into community work.

In Oregon, the rapid growth of the Latino population, from 8 percent (2000) to 11.7 percent (2010) of the State total, has altered the demographics of entire communities (Population Research Center, 2010). The Salem metropolitan area shifted from 15.6 percent Latino to 21.9 percent Latino between 2000 and 2010. By $201011.7 \%$ of 13/4 million of the residents of the Portland metropolitan area was Latino; this population increased 65.7\% from 2000 to 2010 (Population Research Center, 2010). The 
combination of Latino population concentration and immigration history made the metropolitan areas of Salem and Portland valuable case studies for exploring patterns of and barriers to Latino immigrant transnational civic engagement. Many of these immigrants come from communities where regular involvement in civic life is part of a longstanding tradition and local governance (Stephen, 2007). These immigrants are active in HTAs, part of a participatory civic culture that can be tapped to benefit host communities. Yet there is little evidence suggesting public officials in the U. S. are aware of, yet alone have strategies to activate, Mexican immigrant communities. The purpose of this research was to explore patterns and processes of Mexican immigrants' economic, political, and socio-cultural participation in the metropolitan areas of Salem and Portland and with their communities of origin. The implicit goal of the study was to prepare local public officials to work more effectively with this growing population.

\section{Structure of the Dissertation}

This dissertation is organized into seven different but intersecting chapters. Following this introductory chapter, the subsequent chapter offers a literature review of the primary research work to date that addresses aspects of immigrant civic engagement that will be examined in this dissertation. First, the concept of civic engagement is discussed. Next, scholarship on Mexican immigrants' civic engagement in the United States and with their communities of origin is explored. Chapter 3 reports and interprets data on the sociodemographic characteristics of the sample and how they compare to the overall Mexican immigrant population in Oregon. The detailed description of the community sets the context for conceptualization of Mexican immigrants' civic engagement in Oregon. 
Chapter 4 operationalizes Mexican immigrant social, political, and economic civic engagement, adapting and expanding Paasche and Fangen's (2012) theoretical framework on transnational activities to better represent those activities performed by Mexican immigrants in Oregon, of whom a large majority are undocumented and come from rural areas in Mexico.

Chapter 5 provides an overview of the research methods used in this study. A mixed methods approach was used. The quantitative exploration included data to analyze the relationship between civic engagement, including the relationship between civic participation of Mexican immigrants with their communities of origin and their communities of residence in Oregon. The qualitative data provides rich narratives to describe and explain barriers and paths to civic engagement in Oregon.

The findings are structured into Chapter 6, which reports and interprets data on Mexican immigrants' civic engagement in Mexico and in the United States. Quantitative data is used to describe and analyze the impact of sociodemographic variables in civic engagement. Civic engagement indicators were analyzed for their relationship with a set of independent variables such as legal status, demographic characteristics, socioeconomic factors, and characteristics of the immigrant experience. Findings suggest that people are living paralell lives, commited to the development of their communities of origin in Mexico as well as communities of residence in Oregon. This is especially true for those immigrants from rural areas as well as people who have established themselves permanently in the state and are not only are greatful for the opportunity of being in Oregon, but are actively participating in the social, economic and political life of the state. 
This analysis is followed by qualitative findings on paths and barriers to civic engagement among the Mexican immigrant community in Oregon. Most of the Mexicans residing in Oregon are undocumented, hence their political participation has been through joining religious organizations, comunity organizations, some of them with strong political power, and through transnational political participation, such as voting in the Mexican presidential elections and sending money to support their families and towns of origin. On the other hand, findings suggest that people trust and have positive impressions of Oregon police, despite people's legal status, fear of deportation, and loss of vehicles. However, lack of information on how to be involved in civic life seems to be research participants' biggest concern.

The concluding chapter, Chapter 7, summarizes research findings with contributions of this research and future research possibilities based on research findings. This study suggests that local organizations might facilitate the civic engagement of Mexican immigrants in Oregon. In particular, non-profit organizations, religious organizations, and schools seem to be the most neutral places for immigrants to learn more about the community where they currently reside. The findings suggest the need for participatory action research as a way to engage these new residents in their communities of residence. 


\section{Chapter 2 Literature Review}

\section{Civic Engagement Literature}

Promoting citizen participation in social and political spheres has been a major focus of government programs in most democratic countries. The concept of civic inclusion recognizes the relevance of citizens' decisions, helping the State regulate the citizenry using the attitude, space, and resources, leading to further constructive civic engagement (Merino, 1995; Hernández, 1999; Ziccardi, 2000). In this sense, the use of the term "civic society" refers to an inclusive process that is symbolic of democracy (Zicardi, 2000). However, the implementation of policies that aim for civic engagement has differed across countries and across time. For instance, de Tocqueville (1935) pointed out that in the 1800 s, decisions in the U.S. were made by the will of the people, while Putman (2000) argues that, compared to Tocqueville's time, civic engagement is currently weak in the U.S.

Alexis de Tocqueville, a French aristocrat who visited the United States for a nine-month period in 1831 , was fascinated by the American democratic process. He saw a new democratic society based on "equality of conditions" (de Tocqueville, 2003). The Americans' modes of social organization resisted the "tyranny of the majority," according to Tocqueville. These observations came from Tocqueville's comparative analysis to the democratic governments in countries such as France unfolding during the same time period. By analyzing democracy in America, Tocqueville wanted to illustrate its strengths and dangers, and in this way enable the people of other countries to avoid the dangers and reinforce the strengths of the successful American Democracy of the 1800s. He saw that Americans not only shared a common history, but also common objectives. Tocqueville 
found that local government, "the spirit of religion", and freedom of association were the principal features that supported the American democracy of that time. He stated that the great social revolution in America had "nearly reached its natural limits" (de Tocqueville, 2003). Americans were concerned about their wellbeing; therefore, they were eager to participate in issues that could affect them directly or indirectly.

Currently in the $21^{\text {st }}$ century, the United States democracy faces different challenges than those in the 1800 's, consequently changing patterns of civic engagement. Putnam (2000) noted a sharp decline in cooperative civic engagement in the last two decades of the 20th century. However, Johnson (1999) points out that the decline in civic engagement seen by Putman (2000) may correspond to people leaving old social networks to join new ones. If this is the case, the "decline in civic engagement" does not represent "a decline in social capital or civic engagement activities, but a shift in the context and means of involvement" (p. 14). Thus, the decline in civic engagement seen by Putman (2000) may represent a shifting of engagement, structured by people from different nationalities (Ladd, 1999).

Defining civic engagement. Societal participation is a key element of democratic governance. The key rationale for societal participation develops from the principle that policy problems are best resolved by those who are most directly affected (Gibson, 2006). Civic engagement can be understood as individual and community level participation in social and political activities that can influence multiple levels of policy (Putnam, 2000). Mechanisms for citizen participation can be understood as "forms through which public administration facilitates interaction with social actors (collective), depending on the needs, interests, expectations and perceptions of society" (Comisión Intersecretarial para 
la Transparencia [CITCC], 2008). Civic engagement "integrates multiple components of communities and the political landscape in which individuals and groups can get involved in order to adequately connect with decision makers" (García, 2003).

Civic engagement is usually conceived as the participation of citizens in different activities such as "voting, signing petitions, participating in protests, attending religious services, playing on a sports team, contacting public officials, and volunteering, among others" (Gioioso, 2010). Different scholars have developed various frameworks to group these activities. For instance, Keeter et al., (2002) draw a list of 19 core behavioral indicators of civic engagement classified under three major categories: electoral, political, and civic voice. Electoral engagement includes registering to vote, voting, and being actively involved in political campaigns. Political engagement addresses taking an active role in expressing opinions to the media, politicians, organizations, or the general public. Finally, civic engagement also includes (nonpolitical) volunteering, active group membership, and participation in charity work along with efforts to solve community problems.

Theorists strongly emphasize the role of socioeconomic status in the SES model, noting that people tend to civically participate in correlation to their income, education, and occupational status (Putman, 2000). Additionally, according to Warren (2001), faith is a determining component of civic engagement among not only Americans, but also people from other countries, irrespective of social class.

This study focuses on civic engagement from the perspective not only of socioeconomic status, but also the context of the country of residence and the actions and the roles of civic society organizations in the integration of immigrants. 


\section{Immigrants' Civic Engagement}

Scholars have argued that civic participation benefits not only the individual, but also society in general (Putman, 2000). Immigrants' engagement in American society has been studied in order to understand the patterns of immigrants' civic incorporation and the obstacles they face finding their voice in a new country. Stepick et al., (2009) define immigrants' civic engagement as activities carried on through social networks existing outside of the nuclear family. Civic engagement relates to the individual's relationship with both the government and society in general and includes social, political, and economic participation that range from joining churches, social clubs, volunteering at school boards to voting and standing for elections (Fox, 2010; Paasche \& Fangen, 2012).

According to De Graauw (2013), micro-level factors, macro-level factors, and meso-level factors help explain the engagement of immigrants in the U.S. The microlevel factors include the socioeconomic characteristics emphasized by the SES model. Macro-level factors "focus on the role of political institutions and the larger sociopolitical environment in the process of immigrant political incorporation" (De Graauw, 2013). Finally, meso-level factors refer to the mobilization impact of civic institutions on immigrants' engagement in political life of their communities of residence. As De Graauw (2013) suggests, the majority of the current research focuses on the micro-level factors and how socioeconomic status affects the civic engagement of immigrants. This study incorporates macro- and meso-level factors by providing narratives of how institutions and particular issues in Oregon have supported the civic engagement of Mexican immigrants, regardless of their legal status and socioeconomic status. 
Recently Latino civic participation has increased remarkably throughout the U.S. According to DeSipio (2011), a good indicator of the integration of Latino residents is their increasing naturalization rates in the United States. Additionally, the presence of civic engagement among the Latino population can be seen throughout the U.S. Latino immigrants across the country have created organizations, held political and leadership positions, attended marches, written letters to politicians, volunteered in organizations, and donated money for political campaigns, among other kinds of engagement (Bada, Fox, Selee, \& Sánchez Álvarez, 2006).

Religious organizations are also extremely active in civic engagement across the nation and bring together people from different backgrounds. "Churches and other faithbased organizations are structures of first resort for the formation of immigrant social networks" (Bada, Fox, Donnelly \& Selee, 2010). Religious institutions and organizations are considered the first point of contact for Latino civic engagement (Stepic, et al., 2009). Regardless of the era of Latino settlement in American cities, faith-based organizations play a fundamental role in their integration into civic life.

"Church is often the primary, if not only, civic association to which Latinos belong" (Stepick et al., 2009). Religious organizations are important venues for civic engagement across the nation, they gather people from different backgrounds and tend to bridge those differences, benefitting immigrants from their unique organizational form (Stepick et al., 2009; Wuthnow, 1999). Church attendance could serve as a measure to gauge the level of volunteerism people show "both in churches and in their communities" (Stepick et al., 2009). 
According to DeSipio (2011), the increasing number of naturalized citizens in the United States seems to be a good indicator of political participation by immigrants. More than 8.3 million naturalized U.S. citizens voted in the 2008 presidential elections in the U.S. "The immigrant vote grew by more than 1 million from 2004, and the number of naturalized voters increased by more than 1.3 million" (DeSipio 2011, p. 1190).

Several factors influence the integration of immigrants into the civic life in the U.S., many of them sociodemographic indicators. The level of civic participation among immigrants varies depending on income, education, length of time in the United States, ability to speak English, and legal status (Massey, 2010). Many Hispanic immigrants face additional barriers to successful engagement with the local community due to factors such as difficulty with English and legal issues, among others (Massey, 2010). However, it is not necessarily the case that Latino immigrants who face these barriers are uninterested in the development of the American communities in which they live.

The integration of a majority of Mexicans in U.S. civic life is restrained by low levels of education, lack of legal status, and "a polarized hourglass economy that offers few venues of upward mobility without a college education" (p. 349), according to Massey (2010). By the same token, the author argues that both for the first, Mexican born, and second generations in the U.S., the process of integration is difficult without a certain level of educational attainment (Massey, 2010). It is of great value to understand paths and barriers to Mexican immigrants' civic engagement in Oregon, because the majority of this population experience undocumented status in the U.S., low literacy levels, limited English speaking abilities, and rural origins. 
Immigrant civic engagement is also constrained by the context of the society where immigrants live (Fox, 2010). Massey (2010) states that Americans in gateway states are likely to be more tolerant of immigrants than other destination states. In gateway states, local residents tend to be more educated and culturally open; "proimmigrant attitudes generally rise with schooling" (Haubert \& Fussell, 2006). According to Massey, gateway states have been seen as "assimilation machines" (p. 351).

Oftentimes, these states house research centers interested in the integration of immigrants and their descendants and governments are more likely to offer services in multiple languages: "private welfare and social-service agencies are also prevalent to provide material assistance, not to mention immigrants' own hometown associations and other civic organizations" (Massey 2010). On the other hand, in new destination states the integration of immigrants is challenging because they do not find similar assimilation machines and may remain isolated from civic institutions or organizations.

For this project, the context of the receiving society provides a particular interesting dimension for an analysis of immigrant civic participation. The results generated by this research speak specifically to the more urban areas in Salem and Portland, where around 70 percent of the Oregon state Mexican population resides, in contrast to more rural areas of Oregon where the political presence of the Mexican community may still be less noticeable.

\section{Mexican immigrants' transnational civic participation}

The demographic changes in the United States have provided opportunities for Hispanic immigrants to participate in varied local politics in the communities where they currently reside across the United States (Bussel, 2008). Today, around 10 percent of the 
Mexican-born population lives in the United States (Passell \& Cohn, 2011). Many of these immigrants come from communities of indigenous descent, where high and regular involvement in community civic life is customary. While living in the United States, these people often continue contributing to the economy of their communities of origin by joining hometown associations (Rivera-Salgado, Bada, \& Escala-Rabadan, 2005; Stephen, 2007; Velasco-Ortiz, 2005). Social and political networks with their communities of origin have helped immigrants to build civic skills to also participate in American politics. "Politicians, researchers, and activists in both Mexico and the United States have noted the growing importance of these immigrant groups and highlighted their significance as bridges" between Mexico and the United States" (Rivera-Salgado, Bada, \& Escala-Rabadan, 2005).

According to DeSipio (2011), transnational engagement involves immigrants regardless of their legal status in the United States. Guarnizo, Portes and Haller (2003) argue that studies in transnational migration tend to assume that every migrant participates in activities related to transnationalism. Nevertheless, not every international migrant participates in transnationalism, only "a new class of immigrants, economic entrepreneurs or political activists who conduct cross-border activities on a regular basis," are "true transmigrants" (Guarnizo, Portes \& Haller 2003). Guarnizo, Portes and Haller (2003) suggest that less marginalized migrants with higher levels of literacy, who have been in the United States for a longer time, are more likely to follow the political events in their homeland. These kinds of well-established immigrants may be wealthy and are therefore more likely to cooperate with their communities of origin. Comparatively, people who lack documents face not only problems related to their 
survival in the new country, but also problems related to attachment to their communities of origin (Guarnizo, Portes \& Haller).

Undocumented people lack the capacity to be organized in the United States to contribute to their communities of origin due to the many barriers they experience to their presence in the US on a daily basis, according to Massey (2010).

Undocumented status constitutes an unprecedented barrier to immigrant integration. Removing this barrier is an essential first step in giving the new immigrants a fighting chance for realizing the American dream (Massey, 2010, p.352).

However, as stated before, immigrants continue to participate in the civic life of their community of residence, in spite of their legal status (DeSipio, 2011). Improvements in technology continue to strengthen civic engagement in new forms.

Portes, Guarnizo, and Landolt (1999, p. 219) argue that transnational immigrants' civic engagement is "delimited to economic, political, and sociocultural" activities. Paasche and Fangen (2012) present a list of activities that immigrants may perform in each of these three areas. However Paasche and Fangen's framework is developed for legal immigrants. A primary contribution of this study is the expansion of Paasche and Fangen's framework to better capture the civic engagement of Mexican immigrants in Oregon without legal status in the U.S., estimated to be up to $80 \%$ (King et al., 2011).

Mexican immigrants' transnational social engagement. Hundreds of hometown associations (HTAs) now exist across the United States. While some HTAs are informally organized, many have become formal organizations that sponsor fund-raising events to finance philanthropic projects in their towns in 
Mexico. HTAs create and maintain close relationships with the political authorities in their origin communities, and create a sense of community "by strengthening the ties" among migrants living in the United States (Rivera-Salgado, Bada \& EscalaRabadan, 2005). Additionally, "these migrant associations have leveraged their power as counterparts not only of political actors in Mexico, but increasingly of politicians in the United States" (Rivera-Salgado, Bada \& Escala-Rabadan, 2005). HTAs are increasingly participating in the defense of immigrant workers' rights, as well as in the organization of "workers, parents, members of religious congregations and naturalized voters" (Fox, 2005).

The organization of Mexicans in HTAs provides them the opportunity to participate in social and political networks in the United States (Rivera-Salgado, Bada \& Escala-Rabadan, 2005; Velasco-Ortiz, 2005). Many Mexican immigrants work to become engaged members of both U.S. and Mexican societies, constructing practices of “civic bi-nationality" (Fox, 2010). This practice allows them to obtain the necessary knowledge to simultaneously participate in both countries (Fox, 2010).

“Migrant hometown associations' strategies for increasing their clout in home states are closely linked to increasing their legitimacy in the United States" (Richman, 2008, p. 173).

On this subject, Rivera Salgado, Bada, and Escala-Rabadan (2005) discuss the importance of Mexican immigrants belonging to an organization in order to pursue specific goals in the United States and in Mexico. Their research focuses on interviews with former leaders of Hispanic organizations in California, specifically Mexicans, who helped to achieve the right for Mexicans living in the United States to vote in Mexican 
federal elections even if they are not currently living in Mexico. Similarly, through interviews and focus groups with the former organization's leaders, Velasco Ortiz (2005) found how indigenous Oaxacans started gathering in HTAs in Mexico City, Baja California Mexico, and finally, California in the United States. Velasco Ortiz (2005) presents immigrants' narratives about the importance of belonging to an organization and how these organizations have created the foundation for community development in their communities of origin, empowering the voices of those indigenous transnational communities.

In this regard, immigration and social movements across the U.S.-Mexican border have contributed to the development of many Mexican states (VanWey et al., 2005). Additionally, migration has helped in the development of impoverished areas in Mexico and contributed to the restructuring of class and gender roles, especially in rural Mexican communities (VanWey et al., 2005). For instance, communities in Oaxaca, Mexico, have improved their social services by supplementing Mexican government aid with international migrant remittances (VanWey et al., 2005; Reyes Morales \& Gijón Cruz, 2011).

Mexican immigrants' transnational economic participation. Mexico's economy is based on oil, remittances sent from Mexican migrants working abroad, and tourism (Gutiérrez Flores, 2008; Massey \& Parrado, 1994; Villarreal, 2010). The income from oil and remittances fluctuates depending on the year (Lozano Ascencio, 2004). Remittances usually support local and regional development in Mexico and, for this reason, the extent to which the Mexican government would actually be willing to 
implement policies to stop people from leaving the country has been hotly debated (Orozco, 2003; Orozco \& Lapointe, 2004; Wise \& Ramírez, 2010).

In general, the decision to migrate has effects on both the sending community and the receiving community. The decision to migrate affects both specific individuals and their families, as migrants tend to send remittances to their families and by doing so improve the welfare of their communities of origin. Remittances bring changes in household development as they tend to improve a family's health and education.

It is noteworthy that the use of remittances varies depending on demographic and socioeconomic variables, such as age and sex of the household members, the household type (nuclear or extended), female-headed households, and percentage of remittances in total income. The benefits of remittances are not uniform, but disproportionately flow to certain regions of Mexico, and even to particular parts of each Mexican state. The remittance sender's status and characteristics also impact families receiving the remittances differently (Lozano Ascencio, 2003).

When a potential remittance-sender leaves their home community, it is with the objective to improve the condition of life for the family, so community ties remain strong despite years spent living in the new community of residence. Remittances provide additional resources that allow households that receive remittances to consume more goods and services relative to households who are not receiving remittances (Reyes Morales et al., 2009). However, the additional income provided by remittances generally is still not enough to enable these households to start the practice of formal savings and productive investment (Massey \& Parrado, 1994; Reyes Morales et al., 2009; Rubenstein, 1992). In Mexico, remittances play a critical role in alleviating extreme poverty for the 
families who receive them. The percentage of households in relative poverty is significantly higher in households that receive remittances, compared to households which do not receive remittances that experience extreme poverty (Reyes Morales et al., 2009). In the context of Mexico, where poverty is a daily feature in the lives of most people, family networks are fundamental mechanisms for the continued existence and survival of households and the community itself (Orozco, 2003; Orozco \& Lapointe, 2004; Reyes Morales et al., 2009).

In the case of Mexico, remittance flows are usually the major source of foreign exchange in the country. In 2011, remittances totaled approximately $\$ 21$ billion US (Corchado, 2012). According to reports released by the Bank of Mexico (BdeM), in 2007, income from remittances was the main foreign exchange earner for the economy in the first eight months of that year (Conger, 2010). In Mexico, there are states where remittances have played a large role in the state's GDP, as in the case of Zacatecas (11.4\%), Michoacán (11.0\%), Oaxaca (10.6\%), Guerrero (10.0\%) and Hidalgo (8.5\%) (CESOP, 2004). Remittance impact on these Mexican states is concentrated in regions, municipalities, and communities with high rates of international migration, resulting in more money sent to households in these areas (Conger, 2010). Collective remittances, unlike personal or familiar remittances, are defined as: the establishment of a savings fund to support practices undertaken by the organizations serving migrants and as a means of keeping immigrants permanently linked to their home community and help to design public policies in the country of origin (Garabito Elías \& Torres Baños, 2004; p. 244). 
Among Mexican immigrants, money sent to Mexico is often the first expression of migrant organization in the United States (Moctezuma Longoria, 2005; Orozco \& Lapointe, 2004). The Mexican federal government through SEDESOL (Mexican Ministry of Social Development), the state, and municipal governments have incorporated a program to attract and increase the amount of remittances sent by Mexicans abroad, the $3 \times 1$ program (tres por uno) for migrants. For every peso that Mexican migrant associations send to Mexico while living abroad, the federal, state, and municipal governments each contribute one peso respectively, $3 \times 1$ (SEDESOL, 2013). The Mexican federal government initiated the 3x1 program in 2002 and since then it has been widely studied for its impact in the migrant's communities of origin (Fox \& Bada, 2008; García Zamora, 2007; Jáuregui Casanueva, 2008).

"This program allows organized migrants to propose community development project ideas, mainly for small towns and villages, to be funded by collective remittances. Federal, state and municipal governments then vet the proposals. If approved, each level of government contributes matching funds. In principle, local committees oversee project implementation.” (Fox \& Bada, 2008, p. 448).

By the end of 2002 twenty Mexican migrant associations sent around nine million dollars of collective remittances for social infrastructure (Fernandez de Castro et al., 2006). These numbers have grown exponentially in recent years. By 2008 the investment of the $3 x 1$ Program totaled 1.730 billion pesos in 2,457 social projects engaging nearly 574 municipalities and 957 village committees from associations residing in about 37 states in the United States (Rodríguez Cotilla, 2011). According to 
the SEDESOL 2010 report, "2,488 projects were approved, which strengthened ties among Mexicans living abroad and their home communities, performing actions of social infrastructure, coordinated among the three levels of government" (SEDESOL, 2010).

"The 3x1 Program for Migrants supports the efforts of the Mexicans who live abroad and gives them the opportunity to channel resources to Mexico, it works towards social impact that directly benefit their communities of origin." (SEDESOL, 2013)

Mostly, the money used by 3xl Program for Migrants has been allocated towards urbanization, the provision of social services, community centers, the construction of communications and transportation infrastructure, and, in rare cases, commercial investment. The federal government states that "it is neither possible nor desirable for this program to transform social investment into business investment, since it contradicts the nature of migrant organization and collective remittances" (Moctezuma Longoria, 2011). This transnational program not only propels migrants to organize in their communities of residence, but also helps them to keep ties with their communities of origin by contributing to community development (Fox \& Bada, 2008; García Zamora, 2007; Jáuregui Casanueva, 2008).

In the case of this research study, participants' communities of origin mainly used remittances for food, household expenses, education, and medical expenses of family members along with contributions to community festivals. Remittances in communities increase the standard of living of the families of migrants and the people these families interact with, both directly and indirectly. This research generally supports the conclusions drawn from other studies which have found that transnationalism is a family 
activity and/or strategy (Preston, Kobayashi \& Man, 2006; Waters, 2003). Immigrants learn to adapt and socialize in their new communities of residence and with time also learn its social rules and policies. In some cases the immigrant is able to obtain U.S. residency or citizenship, but it is within social and cultural spheres where immigrants' civic participation begins in the United States.

Mexican immigrants' political transnational engagement. "There are 11.7 million foreign-born Mexicans living in the United States, according to the Census Bureau's American Community Survey, 92.3 percent of whom are of voting age" (Villagran, 2012). “In 2011, Mexicans sent an estimated \$21 billion in remittances to families back home, up about 9 percent from a year earlier, but their political clout remains virtually nonexistent" (Corchado, 2012).

In 1990, President Ernesto Zedillo referenced Mexico as a "trans-territorial Mexican nation" (Richman, 2008, p. 178). The Mexican government noticed the large numbers of its citizens leaving the country and implemented policies to take advantage of the situation for national economic development as well as to prevent the continued exodus of its citizens from Mexico (Richman 2008, p. 178). One of these policies was to allow dual citizenship; in 1998 the Mexican Supreme Court authorized dual citizenship for Mexicans (Escobar, 2007; Gutierrez, 1997; Portes, 1999). This policy was found to encourage transnational participation. Similarly, in 2005, then Mexican president Vicente Fox extended the constitutional right to vote to Mexican citizens outside the country (Reyes Romo, 2007; Smith, 2008).

However, only 56,740 of the estimated 4.2 million Mexicans living in the United States registered to vote for the 2006 Mexican presidential elections, (Rivera-Salgado, 
2006). Nevertheless, 33,000 Mexicans abroad voted by mail. The policy presented numerous obstacles that restricted Mexicans living abroad from exercising their right to vote. In order to register to vote in 2006, Mexicans living abroad needed to have a current voting ID card, which until 2015 could only be obtained in Mexico, as well as to pay a fee, and send the ballot through the postal service at their own expense (García, 2011; Lafleur \& Chelius, 2011; Smith, 2008).

For the 2012 presidential elections, there were 61,687 pieces of mail received by the Mexican authorities; the registrations were double the figures for the 2006 elections. The majority of the registrations came from the U.S. $(45,555)$, followed by Canada and to a lesser extent, Spain, France, the U.K. (voto extranjero, n.d.). "According to the count, California ranks the highest in registrations, followed by Texas, Illinois, Florida and New York" (Villagran, 2012).

For the 2012 presidential elections, Mexicans living abroad could register to vote even if their voting card, known as an IFE credential, had expired (Garcia, 2011). Even after this change in policy, the majority of Mexicans living in the United States still could not vote because the only way to apply for an ID voting card was still in-person, in Mexico. For those lacking documentation, who are the majority of Mexican immigrants in the U.S., a trip to Mexico to obtain an ID was too dangerous.

"Federal authorities prevent the vast majority of Mexicans who reside in the United States from exercising their constitutional right to vote by mail by not allowing those citizens to obtain their voter registration cards while in the United States" (Gutierrez, 2012). 
The different forms of Mexican immigrants' transnational civic engagement offer an opportunity to address how immigrants who permanently settled in Oregon interact with Mexican and Oregon politics as well as the affinity they feel with their community of residence versus community of origin.

In summary, demographic shifts are changing "the face of America" (Rodríguez, et al., 2007). The Mexican immigrant population represents the biggest minority in the state of Oregon. The civic engagement of these new residents is important to understand in order to connect them to their democratic representatives. Curiel (2007) argues that Latinos are less likely to vote or engage in political activities because: a) they are more likely to engage in activities that satisfy their primary safety needs such as food and housing, and b) they do not see voting as something that really influences the wellbeing of their community. This resonates with the fact that often Latinos are first involved on issues that directly influence their economic and social progress (Curiel, 2007; DeSipio, 2011). Factors such as the length of time living in the U.S., legal status, and ability to speak English contribute positively to increasing levels of civic engagement among Latinos while the growth of "anti-immigrant sentiment" adversely impacts Latino civic engagement (Curiel, 2007). This study addresses the barriers and paths to civic engagement in the fastest growing Mexican immigrant population in Oregon. Low levels of educational attainment, social class, legal status, and language barriers are factors that present obstacles for Mexican immigrants' engagement and integration in the United States. However, Mexican immigrants' lack of engagement does not necessarily translate into lack of interest in the development and wellbeing of their communities of residence in Oregon, especially true for people with indigenous background. This research 
combines survey and qualitative data to provide the appropriate context and greater understanding of the processes of civic engagement of Mexicans immigrants in a new immigrant destination such as Oregon. 


\section{Chapter 3 Mexicans in Oregon}

Mexican immigrants have settled all over the United States. While they have settled in all regions in Oregon, the Salem and the Portland metropolitan areas have become home, "to both the highest proportion of the Mexican born in the state and where the Mexican-born represent the highest proportion of the overall population" (King et al., 2011). For this Chapter I present the context of Mexican migration to Oregon and describe how the location of this research and the demographic characteristics of interviewees fit within the context of Mexican migration to the State of Oregon.

\section{Mexican Migration to the United States}

From the eighteenth-century to 1803 , The U.S. was mainly populated by white people, "predominantly English-speaking, mainly protestant Europeans" (Hing, 2004). These settlers created the "basis for what many would regard as real Americans" (Hing, 2004). When Europeans first arrived, there were no restrictions on immigration. Each colony had its own policies for attracting new immigrants or for keeping away those that were "undesirable" (Hing, 2004). When the influx of immigrants from non-European countries increased, restrictions on the immigration of "the undesirable" were implemented in order to preserve a certain percentage/number/strength of "the desirable" in the country. From 1875 when the U.S. Federal government began implementing immigration controls (Luibheid, 2002) to today, the history of the United as a "land of immigrants" can be traced by immigration policies that have shaped the United States (Hing, 2004) and the way immigrants and their descendants have been integrated into U.S. society (Perlmann, 2005). 
Immigrants of Mexican descent in the United States represent more than ten percent of the total population (Ortiz Gabriel, 2012). However, their integration into American society has been affected by U.S. policies that have privileged the integration of "whites only" (Hing, 2004; Alba \& Nee, 1997). In general, many of the Mexican immigrants currently residing in the U.S. share similar characteristics that make them not just physically different from the immigrants came to the U.S. in the eighteenth century, but professionally and economically different from the more recent flows of educated and economically advantaged immigrants from India, Taiwan, Iran, or Saudi Arabia (Perlmann, 2005).

Typically Mexicans in the U.S. are undereducated, from rural communities, younger, and about sixty percent lack legal authorization (Rosenblum, et al., 2012; Warren, 2009, King, et al., 2011). Scholars often refer to Mexican immigrants as "labor migrants" (Portes \& Rumbaut, 2006; Perlmann, 2005), highlighting their difference from the "professional or entrepreneurial migrants" (Portes \& Rumbaut, 2006). Nearly a quarter of the current immigrants in the U.S. are college graduates and have a relatively high level of educational attainment, mostly from countries like India, China, Korea, Vietnam or Cuba (Portes \& Rumbaut, 2006). Sixty percent of immigrants from India enter the U.S. through an employment visa while only 3 percent of immigrants from Mexico have entered that way (Portes \& Rumbaut, 2006). While incomes vary widely among immigrants from the same country, when compared to the average U.S. citizen's income, the majority of Mexican immigrants' income falls below this average while some other immigrant professionals and entrepreneurs incomes falls above this average (Portes \& Rumbaut, 2006). 


\section{Mexican migration across U.S. history}

Durand and Massey (2003) identify five phases of Mexican migration to the Unites States. First, some Mexicans came to the U.S. because of the violence during the Mexican revolution. Once the U.S. joined World War I, the newly generated need for cheap labor also brought Mexicans. Many Mexicans remained undocumented in the United States during this time. In the second phase, the U.S. implemented a deportation system (1921-1940), mainly because of its economic crisis and the perceived need to create jobs for its own citizenry. The third phase (1942-1964) started with the signing of the "Bracero Program" and the need for labor caused by World War II. The Bracero Program was a bilateral program that allowed primarily working-age men from rural communities to work in the U.S. temporarily with documents (Rivera Sánchez, 2011). This phase created the primary characteristics of the Mexican immigrants who would come to work in the United States after the "Bracero Program": young men, from rural communities, single or without their families in the U.S., mainly working in agricultural jobs (Durand \& Massey, 2003).

The fourth phase (1965-1986) began when the U.S. canceled the "Bracero Program" and the undocumented Mexican population in the U.S. dramatically increased (Durand, 2007). With this increase of people without legal papers in the U.S., Ronald Reagan enacted the Immigration Reform Control Act (IRCA) in an attempt to secure the border while maintaining the existing cheap Mexican labor force. The fifth phase of immigration occurred with the implementation of IRCA in 1987, when more than two million undocumented Mexicans gained legal status in the United States (Durand \& Massey, 2003). The implementation of this policy later encouraged the arrival of 
thousands of Mexicans to the U.S., primarily undocumented people. IRCA has been seen as a paradoxical policy which did not diminish the undocumented population in the U.S, but rather exponentially increased it (Durand \& Massey, 2003). Currently, with 11 million undocumented people in the U.S., Mexicans represent up to 60 percent of this population and many of whom have settled permanently in this nation (Hanson, 2006).

\section{Mexican Migration to Oregon}

According to the U.S. Census Bureau, $11.7 \%$ of the population in Oregon was of Hispanic or Latino origin in 2010 , compared to $8.04 \%$ in 2000 . Figure 3.1 depicts the general history of Mexican immigration in the state of Oregon. Even if the presence of Mexicans in Oregon is considered a new phenomenon, the presence of Latinos in Oregon goes back to the Spanish explorations in the sixteen century. Spanish explorers first reached the Oregon Coast setting out from Mexico (García, 2016).

As stated by Gonzales-Berry and Mendoza (2010), "the first person of Latino origin listed in the [1850] Oregon census is Guadalupe de la Cruz, a thirteen-year old boy residing in Oregon city," who may have been adopted by an American family. Particularly, Mexicans came to Oregon from 1920 through 1930 as a result of the disturbance caused by the Mexican Revolution (García, 2016; Stephen, Mendoza \& Magana, 2008). Mexico obtained territory from the present-day Oregon-California state line to Central America when it gained its independence from Spain. Spanish Mexicans and indigenous Mexicans worked as miners and mule packers in California and Oregon, a trade that they learned in Mexico (García, 2016). Data from the issuance of money orders to Mexico from Oregon indicated that approximately 50 Mexicans were in the state in 1900, and 85 were in the state by 1910. According to the Oregon census, by 1920 the presence of Mexicans in 
Oregon was 569 due to their employment with the Southern Pacific Railroad (García, 2016).

Later, Mexican workers came in large numbers to the northern Willamette Valley in the 1940s under the U.S.-sponsored Bracero Program (Stephen, Mendoza \& Magana, 2008). During the existence of the Bracero Program, approximately 15,136 Mexicans were contracted as farm and railroad workers in Oregon (Gamboa, 1990; García, 2016). After the Bracero Program ended, many Mexicans overstayed their visas and the undocumented population grew. As a consequence of the increase of this undocumented presence, the military measure Operation Wetback was enacted during the 1950s. In Oregon, according to Lynn Stephen and Marcela Mendoza (2014), "the city of Woodburn and other places where Mexican workers live were punctuated by the presence of sweeps through local farms and roads that picked up undocumented workers."

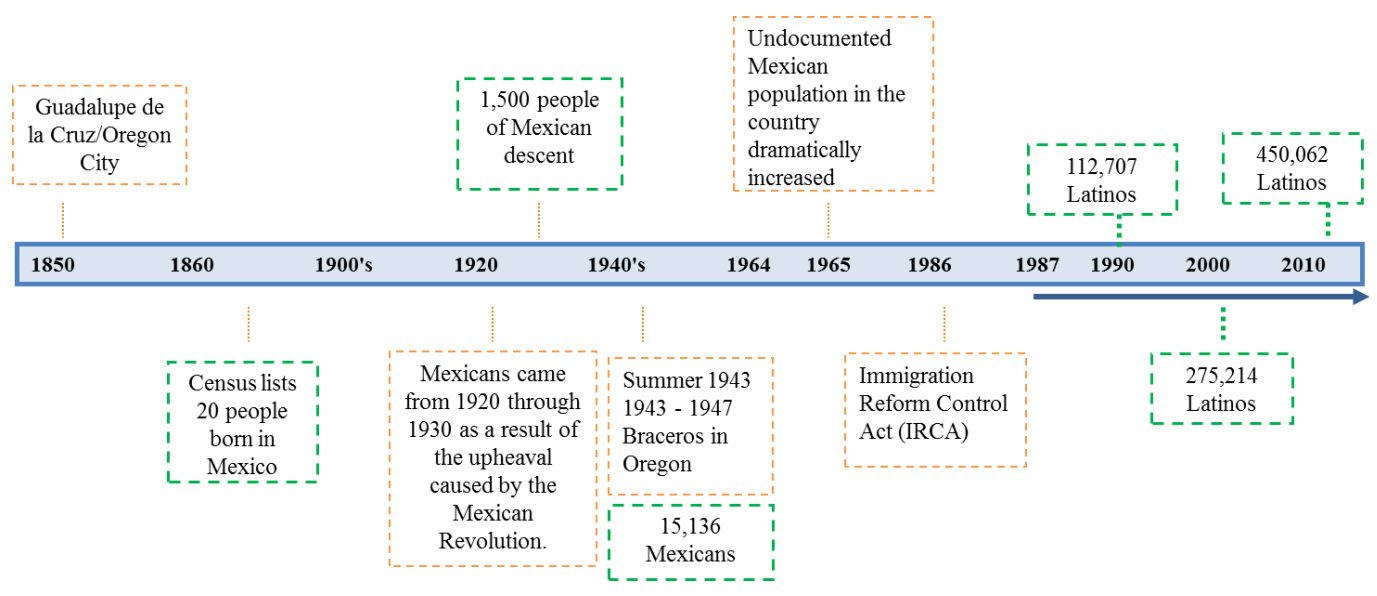

Figure 3.1 General representation of Mexican migration to Oregon

Regardless of the implementation of this policy, the Mexican migration to Oregon continued to grow during the 1950s and 1960s. Since 1965, the presence of 
Latinos in the state has been more visible. For example, the city of Woodburn has a high number of Mexicans and a Spanish language radio station. In 1968 the United Farm Workers of Oregon was established engaging Latinos in civil rights movements (Garcia, 2016).

By 1970, the presence of Mexican migrants in Oregon grew to 32,000. The majority of the new arrivals were from the Mexican states of Oaxaca, Michoacán, and Mexico (Garcia, 2016). The Mexican migration before IRCA was characterized as a temporal or circular one; it was relatively easy to cross the border, migrants "were not exposed to high risk situations and the cost was also cheaper" (Aquino Moreschi, 2012). However, with the implementation of IRCA in 1987, more than 2 million (Durand \& Massey, 2003) undocumented Mexicans gained legal status and settled permanently in the United States. In Oregon, approximately 20,000 Mexicans received permanent residency under this policy (Garcia, 2016). For family reunification and strong social networks, many more immigrants from Mexico came after the implementation of this law, increasing the undocumented population in the U.S. (Aquino Moreschi, 2012).

Since the September 2001 terrorist attack on the twin towers in New York, the U.S. government has implemented stringent measures in an attempt to control the entry of people into the country, as well as reduce the number of undocumented immigrants. The U.S. government has claimed that the U.S.-Mexican border represents a high national security danger and as a consequence the government has enacted more restrictive measures along the border (Aquino Moreschi, 2012). This situation has forced Mexicans coming to the U.S. to take alternative and more dangerous routes, and also 
prevented Mexican immigrants in the U.S. from periodically returning to Mexico as they used to. The more rigorous vigilance along the U.S. border coupled with the implementation of anti-immigrant policies were intended to achieve "self-deportation" of undocumented migrants (Madison, 2012), however have actually ended up facilitating the permanent settlement of Mexican immigrants in the U.S., regardless of their legal status (Portes \& Dewind, 2006).

Today, Mexicans represent the largest ethnic minority in Oregon. "Hispanic immigrants living in Oregon have been establishing their own institutions such as churches, clubs, businesses and other organizations that provide services to them and create social cohesion" (Bussel, 2008). Therefore, Oregon can be considered as an "old and new destination" for Mexican immigrants (Gonzales-Berry \& Mendoza, 2010).

\section{Current Context of Mexican migration in Oregon}

The Mexican population in Oregon has grown substantially, compared to other immigrant nationalities. According to Bussel (2008), "over the last two decades, the face of Oregon has changed dramatically with the arrival of a significant number of immigrants," many of them from Mexico. Immigrants from Mexico represent the largest segment of newcomers to Oregon (King et al., 2011). Over 80 percent of all people classified as Hispanic/Latino in Oregon are of Mexican descent (Bussel, 2008).

According to the Census Bureau's American Community Survey, nearly 11 percent of Oregon residents were born abroad in 2007, of whom 40 percent were born in Mexico, many of them undocumented (King et al., 2011). The Pew Hispanic Center estimated that in 2005, between 125,000 and 175,000 undocumented immigrants were living in Oregon, an estimate that has continued growing (King, et al., 2011). 
Given the importance of the undocumented immigrant population, Table 3.1. shows the legal status of the study participants by sex. Asking about legal status is a sensitive question. I did not inquire about it directly but, informants regularly volunteered information about their current legal status. Both sexes are strongly concentrated in the undocumented status. However, naturalized U.S. citizens and permanent residents account for 48 percent of the sample, 50 percent of men and 38 percent of women.

Table 3.1. Legal status of interviewees

\begin{tabular}{|c|c|c|}
\hline Status & $\begin{array}{c}\text { Men } \\
\text { Percentage }\end{array}$ & $\begin{array}{c}\text { Women } \\
\text { Percentage }\end{array}$ \\
\hline Naturalized U.S. Citizen & 11.5 & 25.0 \\
\hline Permanent Resident & 26.9 & 25.0 \\
\hline DACA* & 11.5 & 4.2 \\
\hline NAFTA** & 3.8 & 0.0 \\
\hline Visa U*** & 0.0 & 4.2 \\
\hline Undocumented & 46.2 & 41.7 \\
\hline \multicolumn{3}{|c|}{$\begin{array}{l}\text { * Deferred action for childhood arrivals (DACA) allows certain people who } \\
\text { came to the United States as children to apply for work authorization for up to } \\
\text { three years. It does not provide lawful status, but the work permit can be } \\
\text { renewed. } \\
* * \text { The North American Free Trade Agreement (NAFTA) Visa is a } \\
\text { nonimmigrant visa for temporary stay and allows citizens of Canada and } \\
\text { Mexico, whose profession is one of the NAFTA professions, to work in the } \\
\text { United States. } \\
\text { ** Visa U is a special visa for victims of certain crimes that cause mental or } \\
\text { physical abuse or for people who help law enforcement or government officials } \\
\text { in the investigation of criminal activity. }\end{array}$} \\
\hline
\end{tabular}

Since 2000, Oregon's population has increased by 419,000, with Latinos accounting for about 43 percent of the state's growth (Hannah-Jones, 2011). Around 12 percent of the state population is Hispanic/Latino, 85 percent of Mexican origin (King et 
al., 2011; Garcia, 2015). Approximately 76 percent of the Portland Metropolitan region's population is Anglo. The Hispanic/Latino population accounts for up to 11.7 percent of this area's population (compared to 12 percent of the state-wide population). However, the Portland-Vancouver-Hillsboro metropolitan area has a Hispanic population of about 224,015 , approximately 66 percent of the Latino population in the state. Similarly, in the Salem metropolitan area, the Hispanic population has increased more than 85,000 from 2000 to 2010, which represents an increase of almost 60 percent (Doussard, 2011). In this sense, Oregon is a new destination for Hispanic immigrants. Fewer families are established in Oregon than in "old destinations", and according to King et al., (2011), a very high proportion of these families lack legal status. Warren (2009) estimates that 95\% of undocumented migrants in Oregon are Mexican.

Many Mexican immigrants have settled permanently in the Unites States and only a few still consider the idea of going back to their communities of origin a viable option. In Oregon, the majority of these new residents maintain relationships with their communities of origin. Mexican immigrants in Oregon connect with their communities of origin by sending money regularly, building houses which may never be inhabited, and participating in organizations that support community development projects in their hometowns,. However, the majority of these residents see their life and the future of their children in the United States. They have established themselves in Oregon and own houses, businesses, and have enrolled their children in schools.

As Table 3.2. depicts, the Portland and Salem metropolitan areas concentrate the largest Hispanic population in the state. Within these areas, the counties that have the largest Latino population in the Portland metropolitan area are Washington and Yamhill 
County. In the Salem metropolitan area Marion and Polk County have the largest Latino population. Figure 3.2. highlights the cities where the respondents for this research reside. All of the respondents live within these four counties except for one interviewee who resided in Lane County.

Table 3.2. Hispanic Population in the Portland and Salem metropolitan areas

\begin{tabular}{|crrrr|}
\hline & $\begin{array}{c}\text { Metropolitan } \\
\text { Portland Area }\end{array}$ & $\begin{array}{c}\text { Metropolitan } \\
\text { Area of Salem }\end{array}$ & Oregon & United States \\
\hline $\begin{array}{c}\text { Total } \\
\text { Population } \\
\text { \% }\end{array}$ & $2,226,009$ & 390,738 & $3,831,074$ & $308,745,538$ \\
$\begin{array}{c}\text { Caucasian } \\
\text { \% }\end{array}$ & 76.3 & 71 & 78.5 & 72.4 \\
$\begin{array}{c}\text { Hispanic } \\
\text { \% }\end{array}$ & 10.9 & 21.9 & 11.7 & 16.3 \\
$\begin{array}{c}\text { Any Other } \\
\text { Race/Ethnicity }\end{array}$ & 12.8 & 7.1 & & \\
\hline
\end{tabular}

Source: U.S. Census Bureau, 2010 


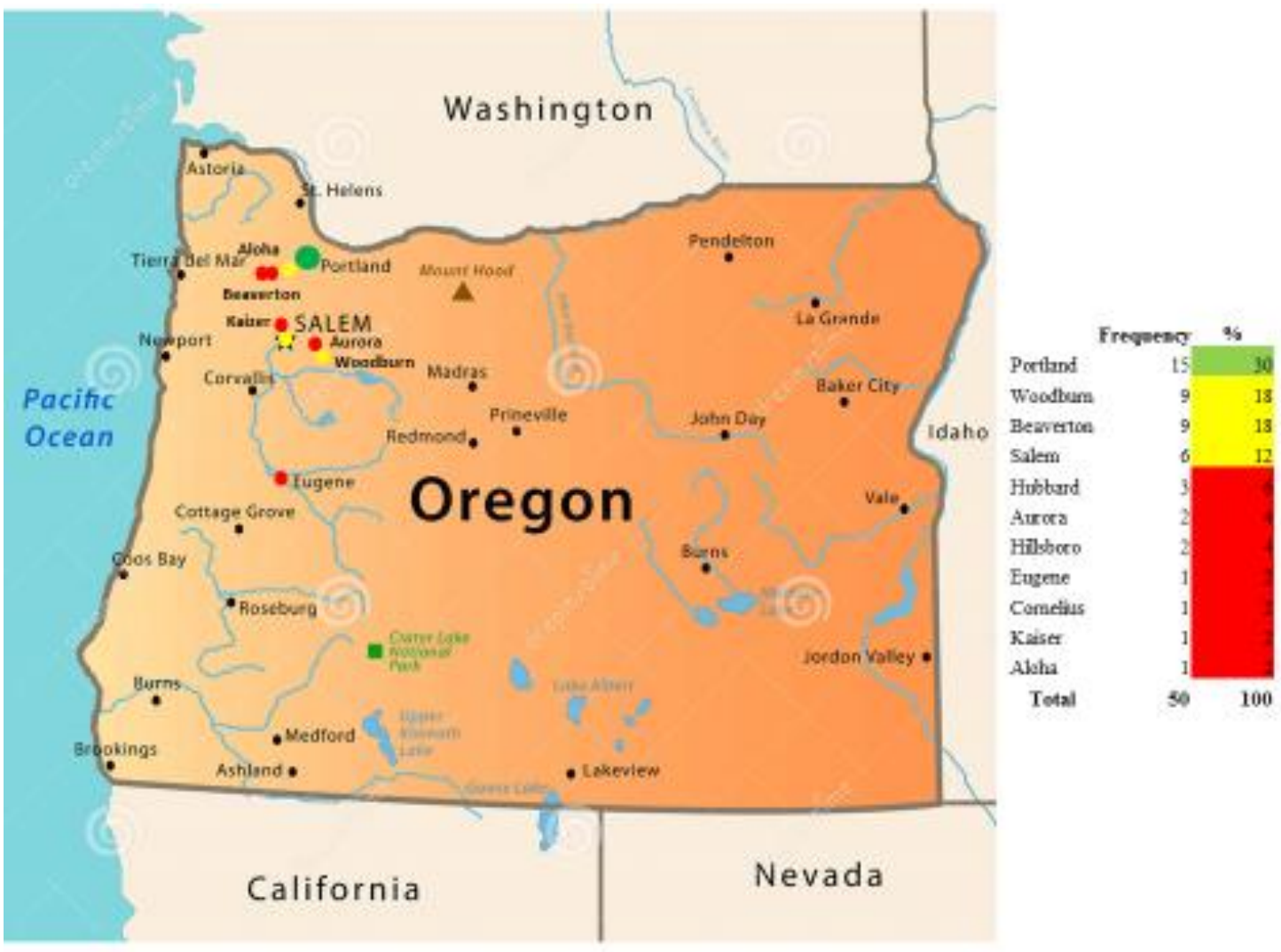

Figure 3.2. Interviewees' place of residence

\section{Sex and age distribution}

Source: Adapted from deamstime, (2015)

The Mexican-born population in Oregon is concentrated in the prime working ages of 24 to 49 (King et al., 2011). Of the 50 Mexican immigrants interviewed, 52 percent were men and 48 percent were women, which mirrors the sex and age distribution of Oregon's Mexican population as reported in the 2005-2007 American Community Survey data (U.S. Census Bureau, 2008).

Figure 3.3. shows the age structure of interviewees by gender. Both sexes are strongly concentrated in the prime working ages between 20 and 50 . The sample is young, with $56 \%$ younger than 40 years old. The men are a little bit older than the women, with a mean age of 45 as compared to 38 . 


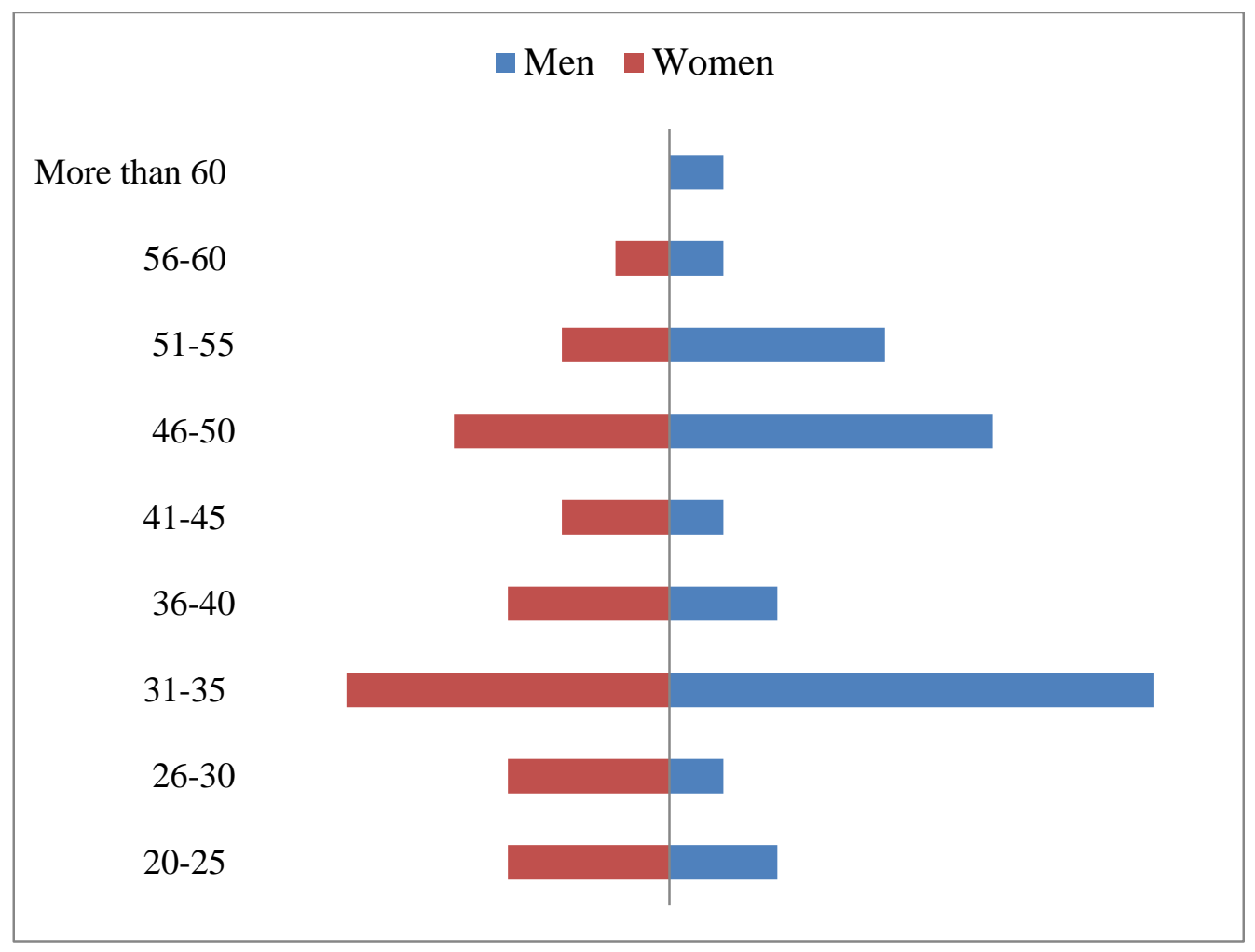

Figure 3.3. Age and gender

\section{Marital status}

Mexicans in Oregon are as likely to be married as native Oregonians (King et al., 2011), although they are more likely to be living apart from their partners, possibly because some of their partners still reside in Mexico. Mexicans in Oregon tend to be less likely to be divorced.

Sixty-eight percent of the sample is either married or cohabitating with a partner. Twenty percent of the study participants were not catholic. Forty two percent of the interviewees had children born in the United States (Table 3.3). 


\section{Rural and urban origin}

The participants in this study mainly come from indigenous communities with a strong tradition of civic participation in local government through the system of "usos y costumbres ${ }^{2} \%$

The majority of the interview respondents were more likely to have been born in urban areas than in rural (66 percent). Women in the sample are slightly more likely to have been born in urban areas, 75 percent compared to 57.69 percent of men born in urban areas.

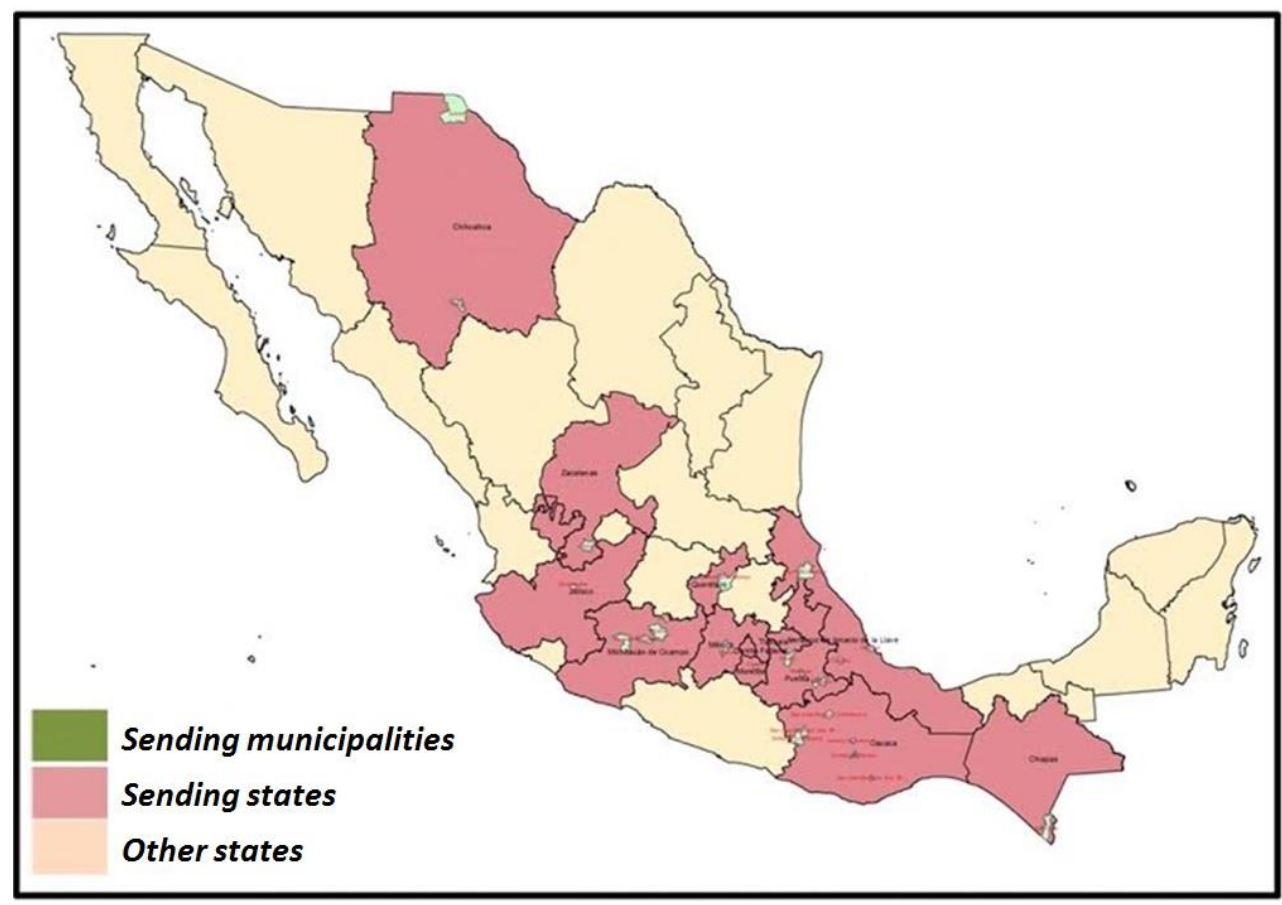

Figure 3.4. Interviewees' communities of origin

${ }^{2}$ Communities under this particular regime govern themselves based on a long-established cultural system, appointing for office those who are considered good citizens in order to help develop and maintain order in the community (Canedo Vasquez, 2008). 
Table 3.3. Demographic characteristics of the sample

\begin{tabular}{|c|c|c|c|c|}
\hline \multirow{2}{*}{ Demographic Characteristics } & \multicolumn{2}{|c|}{ Men } & \multicolumn{2}{|c|}{ Women } \\
\hline & \# & $\%$ & \# & $\%$ \\
\hline \multicolumn{5}{|l|}{ Marital Status } \\
\hline Single & 8 & 31 & 4 & 17 \\
\hline Married & 13 & 50 & 15 & 63 \\
\hline Cohabiting union libre & 3 & 12 & 4 & 17 \\
\hline Divorced & 2 & 8 & 1 & 4 \\
\hline Have children in US & 10 & 38 & 12 & 50 \\
\hline \multicolumn{5}{|l|}{ Religious Affiliation } \\
\hline Catholic & 20 & 77 & 20 & 83 \\
\hline Protestant & 2 & 8 & 1 & 4 \\
\hline Other religions & 4 & 15 & 3 & 13 \\
\hline \multicolumn{5}{|l|}{ Urban or Rural Birthplace } \\
\hline Urban & 15 & 58 & 18 & 75 \\
\hline Rural & 11 & 42 & 6 & 25 \\
\hline \multicolumn{5}{|l|}{ First Language } \\
\hline Spanish & 21 & 81 & 21 & 88 \\
\hline Zapotec & 1 & 4 & 1 & 4 \\
\hline Mixtec & 4 & 15 & 0 & - \\
\hline Purepecha & 0 & & 2 & 8 \\
\hline \multicolumn{5}{|l|}{ Years of Education } \\
\hline $4-6$ & 5 & 19 & 4 & 17 \\
\hline $7-9$ & 4 & 15 & 7 & 29 \\
\hline $10-12$ & 5 & 19 & 4 & 17 \\
\hline $13-15$ & 1 & 4 & 1 & 4 \\
\hline $16+$ & 11 & 42 & 8 & 33 \\
\hline $\begin{array}{l}\text { Some Experience in School in the US } \\
\text { (omitted=studies in Mexico) }\end{array}$ & 9 & 35 & 6 & 25 \\
\hline Homeowner (omitted=renter) & 7 & 27 & 11 & 46 \\
\hline \multicolumn{5}{|l|}{ Employment Status } \\
\hline Full time employment & 20 & 77 & 11 & 46 \\
\hline Part time employment & 1 & 4 & 5 & 21 \\
\hline Self-employment & 2 & 8 & 2 & 8 \\
\hline Not in labor force at time of interview & 3 & 12 & 6 & 25 \\
\hline \multicolumn{5}{|l|}{ Personal Income } \\
\hline Less than 30,000 & 11 & 42 & 16 & 67 \\
\hline Between 30,000 and 50,000 & 10 & 38 & 5 & 21 \\
\hline Between 50,000 and 80,000 & 5 & 19 & 1 & 4 \\
\hline More than 80,000 & 0 & - & 0 & \\
\hline
\end{tabular}




\section{English language fluency}

A large majority of the Mexican immigrants in Oregon reported that they do not speak English at home and 50 percent of them reported not speaking English well (King et al., 2011). In this sample, most respondents self-reported a lack of English fluency, with $60 \%$ describing their competency from "a little" to "gets by", as seen in Table 3.4.

Table 3.4. Level of English fluency

\begin{tabular}{|lcc|}
\hline & $\begin{array}{c}\text { Men } \\
\text { Percent }\end{array}$ & $\begin{array}{c}\text { Women } \\
\text { Percent }\end{array}$ \\
\hline A little & 23.08 & 12.5 \\
Gets by & 26.92 & 16.67 \\
Good & 19.23 & 37.5 \\
Excellent & 30.77 & 33.33 \\
Total & 100 & 100 \\
\hline
\end{tabular}

\section{Homeownership}

Thirty eight percent of the Hispanics in Oregon are homeowners (Pew Research Center, 2016). There were many homeowners among the interviewees (36 percent). Fiftyfour percent of the sample make less than $\$ 30,000$ a year. Thirty percent earn between $\$ 30,000$ and $\$ 50,000$ a year and only twelve percent earn more than $\$ 50,000$ a year. Men earn more money than women, fifteen men earn more than $\$ 30,000$ a year, while only six women so (See Table 3.3).

\section{Occupation}

Mexican immigrant workers in the United States tend to be concentrated in specific industries (King et al., 2010). The sample may reflect that; the majority of the respondents were employed in building and housing remodeling, cleaning and 
maintenance, restaurants, agriculture, and as teachers or teacher assistants, although the sample also captures five business owners, as seen in Table 3.5.

Table 3.5. Occupation of interviewees

\begin{tabular}{|c|rr|rr|}
\hline \multirow{2}{*}{ OCCUPATION } & \multicolumn{2}{|c|}{ Sample } & \multicolumn{2}{|c|}{ Oregon } \\
\cline { 2 - 5 } & $\mathbf{M}$ & $\mathbf{F}$ & $\mathbf{M}$ & $\mathbf{F}$ \\
$\mathbf{\%}$ & $\mathbf{\%}$ & $\mathbf{\%}$ & \multicolumn{1}{c|}{$\mathbf{\%}$} \\
\hline Building and grounds cleaning and maintenance & 7.7 & 25.0 & 12.0 & 15.0 \\
Community and social services & 3.8 & 8.3 & 0.0 & 0.0 \\
Construction and extraction & 26.9 & 8.3 & 18.0 & 1.0 \\
Education, training, and library & 11.5 & 8.3 & 0.0 & 2.0 \\
Farming, fishing, and forestry & 7.7 & 8.3 & 22.0 & 17.0 \\
Food preparation and serving related & 15.4 & 12.5 & 10.0 & 16.0 \\
Installation, maintenance, and repair & 11.5 & 0.0 & 3.0 & 0.0 \\
Management & 3.8 & 8.3 & 3.0 & 2.0 \\
Personal care and service & 0.0 & 4.2 & 0.0 & 6.0 \\
Computer and mathematical & 3.8 & 0.0 & 0.0 & 0.0 \\
Unemployed & 7.7 & 20.8 & 0.0 & 1.0 \\
\hline
\end{tabular}

\section{Education and school enrollment}

The Mexican-born population residing in Oregon is less educated than the general population. However their children, either born in Mexico or in the U.S., tend to be enrolled in school at the same rate as children who weren't born in Mexico. Latino children account for approximately 16 percent of the Oregon population under age 18.

In Oregon, Latino students account for up to $21.04 \%(118,017)$ of Oregon public school students (Oregon Department of Education, 2012). Today, Latinos comprise the second largest group of students in Oregon public schools. However, Hispanic students struggle to finish high school. According to the state's annual public education report, in the 2011-2012 school year, only 56.5\% of Latino students graduated in four years (compared to $70.1 \%$ of their Anglo counterparts (Oregon Department of Education, 
2012). Similarly, Latino students are hardly represented in Talented and Gifted Programs (TAG). Only $8.44 \%$ of students in Oregon's TAG programs are Latinos.

In Mexico, approximately, 61 percent of people between the ages of 25 to 64 have competed upper secondary education (OECD, 2015). The participants in this study averaged higher than usual for educational attainment among Mexican immigrants. Only 18 percent of interviewees have from zero to six years of education. One third of the interview participants attained a ninth grade level of education or less. Approximately one third have some high school education. Fifty eight percent graduated from high school or completed their GED, and almost one third (38 percent) attained more than a high school education.

Interestingly, 30 percent of the sample has participated in some sort of educational experience in the U.S. Some have obtained a tech degree or taken English classes at a community college; others have obtained their bachelor's degree at Portland State University or Oregon State University. The participants in this sample, on average, are more educated than the Mexican-born population in the United States, in which 59 percent of the Mexicans have not earned a high school diploma (Gonzalez-Barrera \& Lopez, 2013).

\section{Characteristics of the Immigrant Experience}

The majority of the Mexican immigrants living in Oregon come from the states of Michoacán, Oaxaca and Jalisco (Instituto de los Mexicanos en el Exterior [IME], 2010). Similarly, a large proportion of this study's respondents (48 percent) also came from these three Mexican states (See Table 3.6). 
Table 3.6. Characteristics of the intervieweews

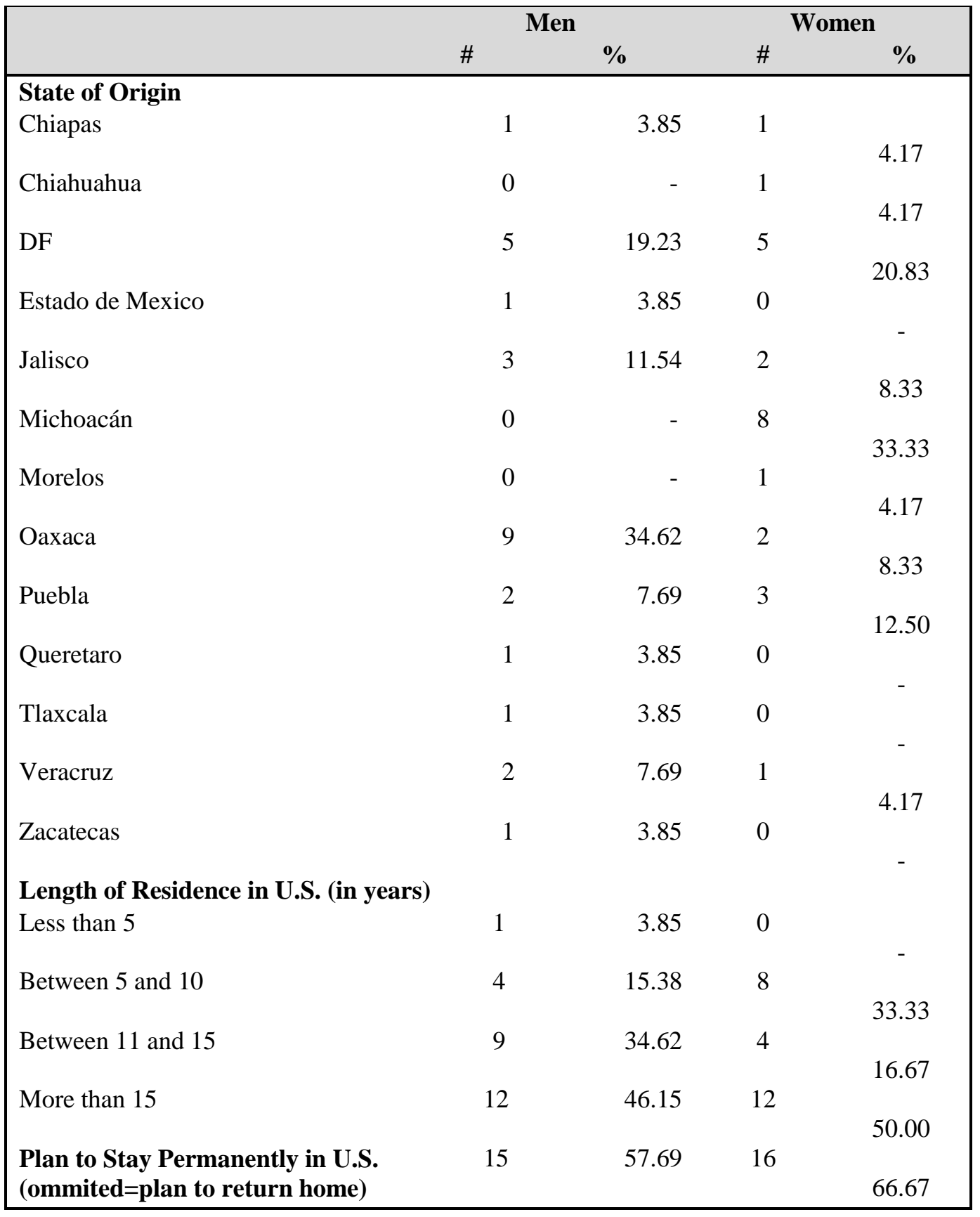

Mexican migration to Oregon is relatively new. The majority of adult Mexican immigrants came in the last 20 years. Approximately 40 percent of these immigrants arrived in the U.S. between 1990-1999 (King et al., 2011). Similarly, most of the 
participants have been in the United States for more than five years: only one interviewee has been in the U.S. for less than five years; 24 percent have been in the U.S. between five and ten years; 74 percent have been in the U.S. for more than ten years, with a mean of sixteen years amongst study participants. The large majority of interviewees plan to stay permanently in the United States regardless of their legal status, (See Table 3.6).

The impact of pro-immigrant organizations in Oregon. The role of pro-Latino organizations across the United States has been crucial in integrating Latinos within American society (Stepick et al. 2009; Velasco-Ortiz 2005). Latino organizations in the cities of Chicago and Los Angeles provide remarkable examples of how pro-immigrant organizations can achieve common goals in cities where Latinos have settled for longer periods and powerful immigrant advocacy groups already exist. For instance, Chicago's 2006 pro-immigrant mega-march was the largest in the U.S.; approximately 300,000 people, mostly U.S. citizens, participated in that public demonstration (Bada, Fox, Donnelly \& Selee, 2010). This success can be attributed to the fact that Latino organizations have been able to establish a "common cause and engage more effectively with African-Americans and non-Latino immigrants" (Bada, Fox, Donnelly \& Selee, 2010; p. 55).

In the state of Oregon, organizations such as the Beaverton Hispanic Center (BHC), CAUSA (Oregon's Immigrant Rights Coalition), VOZ Workers' Rights, and the Northwest Treeplanters and Farmworkers United, (in Spanish Pineros y Campesinos Unidos del Noroeste) more commonly known as PCUN, provide linkages for immigrants from the same ethnicity (viz. Latinos/Hispanics) rather than people from other countries or Americans. 
As a response to the increase in the undocumented population, numerous states, including Oregon, implemented polices that restrained services to the undocumented population (Archibold, 2010). For instance, in 2008, Oregon SB 1080 established that the Oregon Department of Transportation (ODOT) would require proof of both legal presence in the United States and Social Security number in order to renew or replace any driver's license, driver's permit, or identification card. As driving their own cars appears to be the most frequent means of transportation that Mexican migrants use to go to work, go shopping, or participate in recreational activities, even if they cannot apply for a driver's license, many of them will continue to drive without this document (King, et al., 2011). Additionally, as in the United States a state ID or a driver's license is the main form of identification used to access the majority of services, immigrants unable to obtain a driver's license face constraints in accessing those services, which affects entire families (King, et al., 2011). Many Mexican immigrants have managed to obtain fake ID's. Other Mexican immigrants in Oregon obtain a driver's license from the State of Washington by temporarily changing their place of residence, moving to the state, or by asking a family member or friend residing in Washington to be included in their rental lease or in the bills. However, many are driving without a driver's license (King, et al., 2011)..

Anti-immigration policies implemented across the United States have challenged immigrants and activists to join and fight for their rights (Voss \& Bloemraad, 2011). Immigrant organizations such as PCUN, the Oregon's Farmworker Union (Northwest Treeplanters and Farmworkers United), Oregon's Immigrant Rights Coalition (CAUSA), Mujeres Luchadoras Progresistas, Hispanos Pros, Adelante Mujeres, among others, 
accompanied by U.S. citizens and other immigrants, have implemented protests and rallies against SB 1080 to support “the restoration of driver's licenses to all Oregon residents who meet the qualification for a standard license, regardless of ability to prove citizenship or legal status" (CAUSA, n.d.). Lobbying for driver's licenses for undocumented immigrants has become the number one priority for pro-immigrant organizations in the state of Oregon.

Similarly, despite the fact that the majority of Mexicans in Oregon are undocumented (95\%) (Warren, 2009; King et al., 2011), younger, have low levels of literacy, and are from rural communities (Rosenblum, Seelke, \& Wasem, 2012), the Mexican community in Oregon, in conjunction with its allies, has achieved the passage of bills where undocumented immigrants are allowed to obtain a driving permit or enroll at a University (Jones, 2013; Graves, 2011; Zheng, 2013). This success has created a climate where immigrant political organization has gained relevance regardless of their legal and/or economic status. More recently, CAUSA, along with other organizations, has been involving immigrants in lobbying for laws related to the U.S. minimum wage and English as a second language in public schools.

Since then, strong pro-immigrant organizations such as CAUSA and PCUN have focused their efforts on restoring driver's licenses for undocumented people. SB 1080 has to some extent harmed the integration of Mexican immigrants into the Oregonian communities where they reside. However, many Mexicans came to Oregon after having lived in other states such as California, Texas or Arizona, and for them Oregon is still a welcoming state. Mexican immigrants living in Oregon are very much appreciative of its natural beauty and people's acceptance in the main metropolitan areas. 


\section{Summary}

In conclusion, "white and English speaking” people from European descent came first to the U.S., setting the precedence for what were considered "real Americans" (Hing, 2004). Most of the Mexican migrants shared different physical characteristics from the first pioneers and different economic and educational levels from other waves of immigrants. Mexicans have come to the U.S. primarily for economic reasons. Historical patterns of Mexican migration across U.S. history, the strong social networks, and the current violence in Mexico may also play an important role in understanding this migratory experience. After IRCA, the undocumented Mexican population (both men and women) in the U.S. grew exponentially. Continued anti-immigrant policies and strong enforcement along the U.S.-Mexico border has led to further undocumented people from Mexico settling in the U.S., irrespective of their legal status.

The majority of Mexicans in Oregon are undocumented (95\%) (Warren, 2009; King, et al., 2011), are younger, have lower levels of literacy, and are from rural communities (Rosenblum, et al., 2012). This sample of interviewees contains a higher proportion of people with education and English language proficiency, however, the Mexican community in Oregon has achieved the passage of bills where undocumented immigrants are allowed to obtain a driving permit or enroll at a University (Jones, 2013; Graves, 2011; Zheng, 2013). This has created a climate where Mexican immigrants have gained visibility regardless of their legal or economic status. 


\section{Chapter 4 Conceptual Framework}

This theoretical framework combines the definition of transnational activities economic, political and sociocultural -within Paasche and Fangen's (2012) analytical framework (economic activities, political activities, and sociocultural activities), examining the engagement of immigrants in Mexico and in the United States, despite their lack of legal status and economic situation in the United States.

This mixed methods study builds upon Paasche and Fangen's (2012) argument that transnationalism pattern analyses are better understood through mixed quantitative and qualitative methods.

Reflections on transnationalism and transmigrants are often either theoretical or based on qualitative case studies. As these case studies tend to focus on migrants who are involved in transnational activities, they give the impression that transnationalism has become the major form of immigrant incorporation (Snel et al., 2006).

The research in this analysis is based on Paasche and Fangen's (2012) list of civic activities people might perform while living in a foreign country: professional economic activities, everyday economic activities, political activities and sociocultural activities. This generic framework applies to more stable immigrants, including those with and without legal status (See Table 4.1.).

The majority of the Mexican population in Oregon arrived in the U.S. in the last two decades (King et al., 2011). Many still lack legal status and come from rural communities. Therefore, a substantial contribution of this project is a proposed modification of the framework to better incorporate undocumented immigrants and 
indigenous immigrants with strong histories of civic engagement. I included categories related to their participation through their community of origin's traditional system of government and their engagement in pro-immigrant organizations in Oregon (See Table 4.2.). It is noteworthy that according to Stepick et al. (2008), immigrants' civic activities include not only involvement with political and legal spheres, but also with those activities they participate in through social networks existing outside of the nuclear family. In order to identify these activities, individuals' involvement with both the government and society in general were also included- economic, political, and sociocultural participation activities that ranged from joining churches, social clubs, and volunteering at school boards to voting in and running for office (Fox, 2010).

\section{Table 4.1. Overview of transnational activities}

\begin{tabular}{|c|c|}
\hline \multicolumn{2}{|c|}{ Everyday Economic Activities } \\
\hline i) & Transfers money to family \\
\hline ii) & Sends goods to country of origin \\
\hline iii) & Owns house in country of origin \\
\hline iv) & Contributes to charities in country of origin \\
\hline \multicolumn{2}{|c|}{ Professional Economic Activities } \\
\hline i) & Invests in companies in country of origin \\
\hline ii) & Conducts trade with country of origin \\
\hline iii) & Visits country of origin for business \\
\hline \multicolumn{2}{|c|}{ Political Activities } \\
\hline i) & Reads newspapers from country of origin \\
\hline ii) & Keeps in touch with politics in country of origin \\
\hline iii) & Member of political party in country of origin \\
\hline $\mathrm{v})$ & Gives money to political party in country of origin \\
\hline vi) & $\begin{array}{l}\text { Participates in demonstrations, political campaigns, or rallies related to } \\
\text { country of origin }\end{array}$ \\
\hline \multicolumn{2}{|r|}{ Sociocultural Activities } \\
\hline i) & Member of organization related to country of origin \\
\hline ii) & Attends meetings with primarily compatriots \\
\hline iii) & Attends cultural events \\
\hline
\end{tabular}

Source: Paasche and Fangen ( 2012) 
This study analyzes the relationship between civic engagement of Mexican immigrants in Oregon, their legal status, demographics, their immigrant experience and their socioeconomic status, as depicted in Figure 4.1. Indices of civic engagement (political, economic and social) were created by summing the positive responses to active engagement in each category. Independent variables for which the study controls are legal status, age, gender, marital status, employment status, educational attainment, experience enrolled in school in the U.S., homeownership, personal income, birth place, length of U.S. residence and permanency plans.

\section{Level of Civic Engagement}

Civic engagement is the outcome variable explored in this study. Civic engagement is generally understood as individual and community level participation in social and political activities that influence multiple levels of policy (Putnam, 2000). Civic engagement integrates multiple components of communities and the political landscape in which individuals and groups may engage to connect with decision makers (García, 2003). For purposes of this research, civic engagement is understood as "both political participation and civic voluntarism" (Ramakrishnan \& Baldassare, 2004). Civic engagement can be categorized into social, political and economic participation, which ranges from joining churches, social clubs, volunteering and/or running for office (Fox, 2010). Therefore, in this study civic engagement is understood as the respondents' economic, political and social involvement in the U.S. and with their communities of origin in Mexico. Figure 4.1 shows the contextual factors (independent variables) that are taken into account in this study and those that affect levels of civic engagement among the immigrant population studied. 


\section{Economic activities}

Economic activities refer to the respondents' attitudes towards contributing economically to their communities of origin and their economic engagement in their communities of residence in Oregon. The variables to measure economic engagement in the U.S. are whether the participant owns a house, contributes to charities and invests in companies in the U.S. The underlying assumption in measuring economic engagement is that the greater economic contribution an immigrant makes, the more they are willing to participate in civic affairs in the U.S. (Goldring \& Landolt, 2012). Similarly, Mexican immigrants' economic engagement with their communities of origin is measured by whether or not the interviewee transfers money to their family, contributes to charities or churches and owns property in Mexico.

\section{Political Activities}

In this study, engagement in political activities is defined as Mexican immigrants' participation in political activities related to Mexico and/or to the U.S. As mentioned before, $44 \%$ of the sample is undocumented, making some forms of engagement in political activities such as casting a ballot in U.S. elections impossible. However, political engagement in the form of membership in one of the strongest political organizations in the state was common among both documented and undocumented interviewees.

Paasche and Fangen (2012) focus on electoral political activities. Mexican migrants in Oregon who come from rural communities and frequently have an undocumented immigration status may not donate to political campaigns in Mexico, but may have held positions of responsibility in their home communities due to "usos y costumbres", a local government system based on traditional practices, which in the past 
was largely run by and for men. Communities under this particular regime govern themselves based on a long-established cultural system, appointing for office those who are considered good citizens in order to help develop and maintain order in the community (Canedo Vasquez, 2008; Carlsen, 1999).

Undocumented immigrants do not vote, but they may participate politically in other ways, including engaging in political campaigns or being members of immigrant organizations with strong political representation in the state. Due to this different type of political engagement, I have added important subcategories of Political Activities, including membership in longstanding local Latino organizations such as Oregon's Immigrant Rights Organization (CAUSA), Northwest Treeplanters and Farmworkers United (PCUN), or attendance at meetings of pro-immigrant organizations such as CAUSA or PCUN.

\section{Sociocultural Activities}

As stated by Itzigsohn and Saucedo (2002), sociocultural transnationalism "concerns the emergence of practices of sociability, mutual help, and public rituals rooted in the cultural understandings that pertain to the sense of belonging and social obligations of immigrants. [It is] more affective oriented and less instrumental than political or economic transnationalism" (p. 768). Social engagement with the community of origin is also seen as the most frequent type of transnational engagement (Preston et al., 2006). Immigrants engage transnationally by more than just visiting their home country, through the concept of social transnationalism. Social transnationalism can be seen as a "way of being", a "way of belonging" and a way of demonstrating commitments to people and the community of origin (Levitt \& Jaworsky, 2007; Paasche \& Fangen, 2012). 
Mexican immigrants' participation with social and charitable organizations related both to their country of origin and those based in Oregon were measured in this study. Tables 4.2 and 4.3 summarize the dependent variables measured within each category type of engagement: economic, political and social. Sociocultural activities include all those social activities that people perform outside of their family (Stepick et al., 2009), such as attending church, recreational activities, and school-related gatherings. 


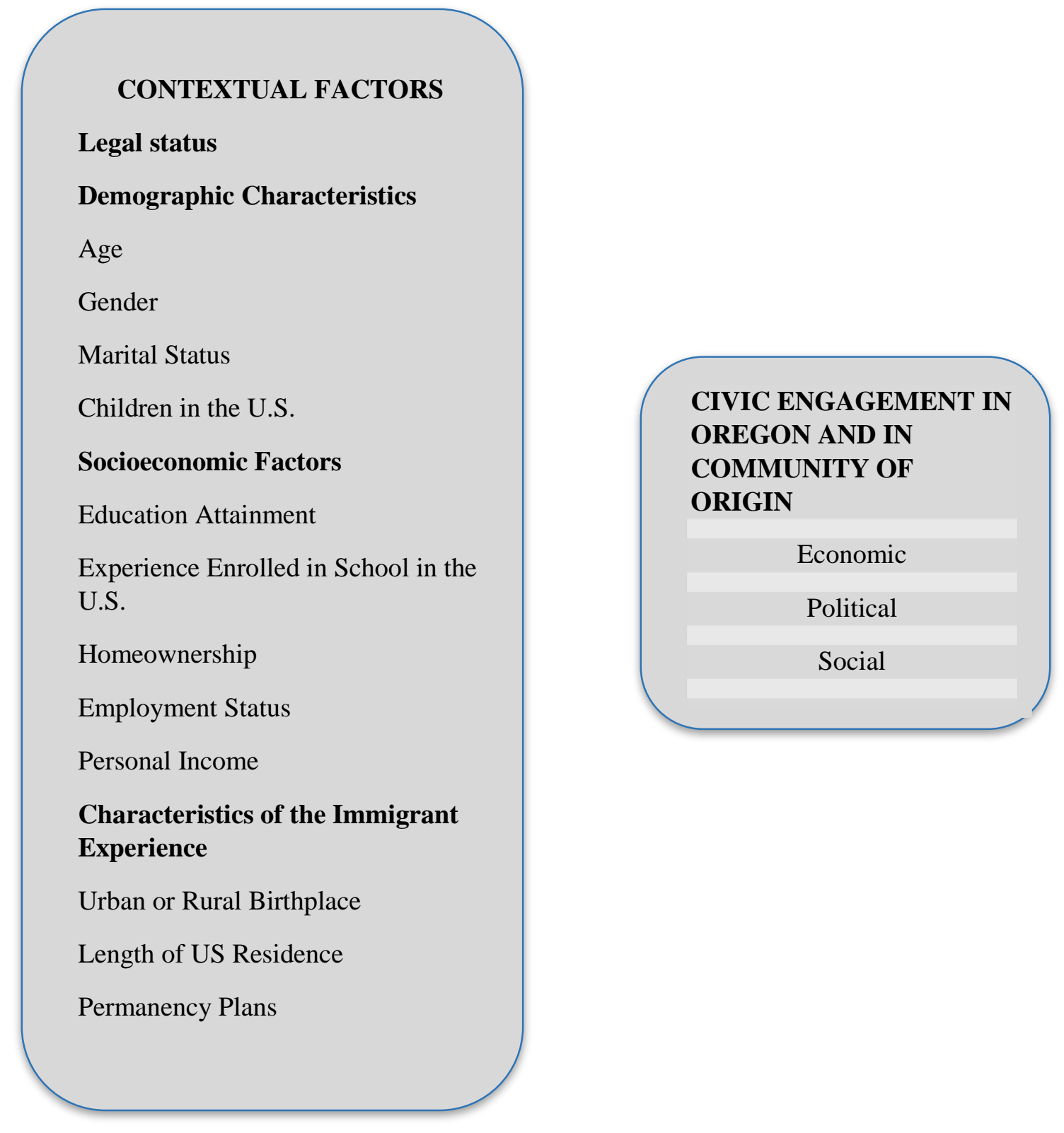

Figure 4.1. Conceptual diagram 


\section{Table 4.2. Overview of immigrants' transnational activities in their communities of origin}

\begin{tabular}{|c|c|}
\hline \multicolumn{2}{|c|}{ Economic Activities } \\
\hline iv) & Transfers money to family \\
\hline v) & Contributes to charities church, or hometown association in Mexico \\
\hline vi) & Owns house in Mexico \\
\hline \multicolumn{2}{|c|}{ Political Activities } \\
\hline i) & $\begin{array}{l}\text { Reads and/or discusses newspapers or online news, listens to the radio, } \\
\text { or watches TV from country of origin }\end{array}$ \\
\hline ii) & Keeps in touch with politics in Mexico \\
\hline iii) & Voted in the last Presidential Elections in Mexico \\
\hline iv) & Member of political party in Mexico \\
\hline v) & Gives money to political party in Mexico \\
\hline vi) & $\begin{array}{l}\text { Participates in demonstrations, political campaigns, or rallies related to } \\
\text { country of origin }\end{array}$ \\
\hline vii) & Holds positions of responsibility in their home communities \\
\hline \multicolumn{2}{|c|}{ Sociocultural Activities } \\
\hline iii) & Member of an organization related to Mexico \\
\hline iv) & Attends meetings with primarily compatriots \\
\hline iii) & Visits cultural events in Mexico \\
\hline
\end{tabular}

Source: Adapted from Paasche and Fangen (2012) by the author to better fit the situation of undocumented immigrants in Oregon

Table 4.3. Overview of immigrants' civic engagement in Oregon

Everyday Economic Activities
i) $\quad$ Owns house in Oregon
ii) $\quad$ Contributes to charities in Oregon
Professional economic activities
i) Invests in companies in Oregon
Political Activities
i) $\quad$ Reads newspapers or online news, listens to the radio, or watches U.S.
ii) $\quad$ Keeps informed about politics in Oregon
iii) $\quad$ Member of a political party in Oregon
ii) $\quad$ Have you voted in the U.S.?
iii) $\quad$ Participates in demonstrations, political campaigns, or rallies in Oregon
iv) $\quad$ Member of a pro-immigrant organization such as CAUSA or PCUN
v) $\quad$ Registered to Vote
Sociocultural activities
i) $\quad$ Member of social organizations in Oregon
ii) $\quad$ Attends sociocultural meetings in Oregon

Source: Adapted from Paasche and Fangen (2012) by the author to better fit the situation of undocumented immigrants in Oregon 


\section{Independent Variables/Contextual Factors}

The contextual factors, under the dimensions of demographic characteristics, socioeconomic factors and characteristics of the immigrant experience affect civic engagement directly. Demographic characteristics include age, gender, marital status, income, length of time in the U.S., and whether the respondent has children in the United States. The socioeconomic status variables used in this study are educational attainment, experience enrolled in school in the U.S., homeownership, employment status and personal income. Urban or rural birthplace, length of U.S. residence and permanency plans comprise the characteristics of the immigrant experience.

\section{Demographic Characteristics}

Age. Previous studies suggest that older people tend to have higher levels of civic engagement. However, Mexican immigrants are relatively younger than the general American population (Putman, 2000; U.S. Census, 2010). Therefore, this study assesses whether age has a similar relationship with civic engagement as in other studies (Martinson \& Minkler, 2006).

Gender. Gender appears to play an important role in how immigrants engage in their receiving society and within their communities of origin (Hondagneu-Sotelo, 1994; Itzigsohn \& Giorguli-Saucedo, 2005). Men have higher voting rates in the United States (Putman, 2000), and male Mexican immigrants are more engaged in their communities or origin than in their communities of residence. Mexican women may be more engaged in communities of residence, through schools and other organizations. Usos y costumbres now provide far more roles for men and women. In the last few decades, women have become more engaged in community affairs in both the U.S. and Mexico, but historically, 
men have been the primary particianpts in public affairs in their communities of origin (Canedo Vasquez, 2008; Carlsen, 1999).

Gender is included in this study to determine if it has the same relationship with civic engagement as that found in former studies in traditional immigrant destinations in the United States.

Marital status. Marital status refers to whether the respondent is married, cohabitating, divorced or single. Literature suggests that being married has a positive association with civic engagement (Putman, 2000). This variable is included in this study to understand its association with civic engagement for this specific sample, since Mexican immigrants present high rates of marriage but low levels of civic engagement (Rosenfeld, Messner, \& Baumer).

Children in the U.S. Having children enrolled in U.S. schools increases the probability of parental engagement, similarly, those with children born in the U.S. may be more likely to engage with the broader society looking after their children's future in the U.S. (Carreón, Drake, \& Barton, 2005; Loges et al., 2003; Wilkin, Vikki, \& Sandra, 2009).

\section{Socioeconomic factors}

Educational attainment. Higher levels of educational attainment help individuals to create connections with their community and government (Gándara \& Contreras, 2009). More schooling is directly associated with higher levels of civic engagement, which includes the knowledge of opportunities of how to be politically involved within the broader society (Garcia, 2003). 
Experience enrolled in School in the US. Immigrants with even short experiences within the U.S. education system may be more likely to look for opportunities to be civically engaged in the United States (Crosnoe, 2006; Lopez, 2001).

Homeownership. Literature suggests that homeownership is positively related to higher levels of civic engagement in the US (Barreto, et al., 2008; Putman, 2000).

Employment status. The level of involvement in the US labor market is associated with socioeconomic status and positively related to higher civic engagement (Sugrue, 1996).

Personal Income. Household income can determine one's ability to participate outside of the workplace (Bacon, 2008). For low income Mexican families, income determines their ability to interact with others who may let them know about civic opportunities and resources available.

\section{Characteristics of the Immigrant Experience}

Urban or rural birthplace. Urban and rural birthplace is included as an immigrant characteristic to examine the influence of the respondents' birthplace and their civic engagement in the United States. Immigrants coming from rural communities may have a greater propensity to get involved in their communities in residence in the U.S., as is the case in Mexico (Martínez Nateras \& Stanley, 2009; Stephen, 2007).

Length of U.S. residence. Studies show that the longer a person remains in a new place, the more they get used to and willing to participate in that society, its culture and its government (Tucker \& Santiago, 2013).

Permanency plans. Permanency plans is included in this study to understand its role in Mexican immigrants civic engagement. Those who do not plan to stay in the U.S. 
for the rest of their lives may be less likely to be interested and invested in the society and politics of the U.S. (Tucker \& Santiago, 2013). 


\section{Chapter 5 Methodology}

In order to address the research questions put forth for this study, a mixed methods approach was used that examined data from a semi-structured interview with Mexican immigrant residents in the northwest quadrant of the state of Oregon. In this

chapter, I provide a detailed description of the data and methods for both the quantitative component, based on analysis of close-ended questions, and the qualitative component reporting answers to open-ended questions. In particular, this chapter describes the mixed methods research methodology, participants, sampling methods and procedures. Then, I describe data collection procedures and data analysis. Finally, this chapters reviews the limitations of the study, as well as strategies used for validating the findings and minimizing research bias.

\section{Purpose of the Study and Research Questions}

The purpose of this research project is twofold: first, to undertake a quantitative exploration of Mexican immigrants' civic engagement, including the relationship between civic participation of Mexican immigrants within their communities of origin and their communities of residence in Oregon and second, to describe and explain barriers and paths to civic engagement in Mexican immigrants' communities of residence based on qualitative data. The level of analysis for my research was focused at the individual level.

The research questions during the study were:

1. How civically engaged are Mexican immigrants in Oregon? Does civic engagement differ by gender, age, indigenous background, economic and legal status, length of time in the U.S., English fluency and education level? 
2. Does the engagement of immigrants with their home communities detract from engagement in Oregon, or enhance it? Has this relationship changed over time?

3. What are the issues with which participants are most often engaged in their communities of residence?

4. What are the barriers that most deter participants from civic engagement in their communities of residence?

5. Which organizations do this group of immigrants work with on civic issues? How?

\section{Mixed Method Research (MMR)}

The use of mixed methods is becoming common in social sciences and other disciplines including public administration and political science (Feilzer, 2010; Harrits, 2011; Molina-Azorin et al., 2012). A mixed method study integrates both qualitative and quantitative data collection and analysis in a single study (Johnson \& Onwuegbuzie, 2004; Morgan, 1998; Creswell, Plano Clark, Gutmann, et al., 2003). A semi-structured interview is the main tool I used to collect data and allows me to make correlations and crosstabs considering immigrant's demographics and levels of civic engagement. The interview also provides narratives and detailed experiences of Mexican immigrant's civic engagement in Oregon and in their communities of origin. In addition, I conducted participant observation, in several contexts and locations for a period of four years, to better understand the social context in which Mexican immigrants live in the metropolitan areas of Portland and Salem, Oregon.

Specifically in the context of this research to explore patterns of Mexican immigrants' civic engagement in Oregon and in their communities of residence, the 
mixed method design may help to improve current research by giving us access to different kinds of data and helping us understand these patterns and barriers than by solely using quantitative or qualitative methods (Paasche \& Fangen, 2012). The integration of both kinds of data allows me to capture a fuller picture of Mexican immigrants' civic engagement. Particularly, having closed-ended questions in addition to open-ended questions about paths and barriers to civic engagement allowed me to analyze how interviewees understand their own civic engagement in their communities of residence in Oregon and in their communities of origin in Mexico.

\section{Triangulation Design in Mixed Methods Research}

The triangulation design in mixed methods research was used in this study (Creswell \& Plano Clark, 2011). The triangulation method consists of a single phase: incorporating both quantitative and qualitative approaches. Each type of data can be analyzed separately and independently, using techniques associated to meet the researcher's needs and expertise (Creswell \& Plano Clark 2011). This method integrates both qualitative and quantitative research to counterbalance bias and limitations from the use of a single method and enhances the validity of the research (Denzin, 1978; Jick, 1983). (See Figure 5.1). 


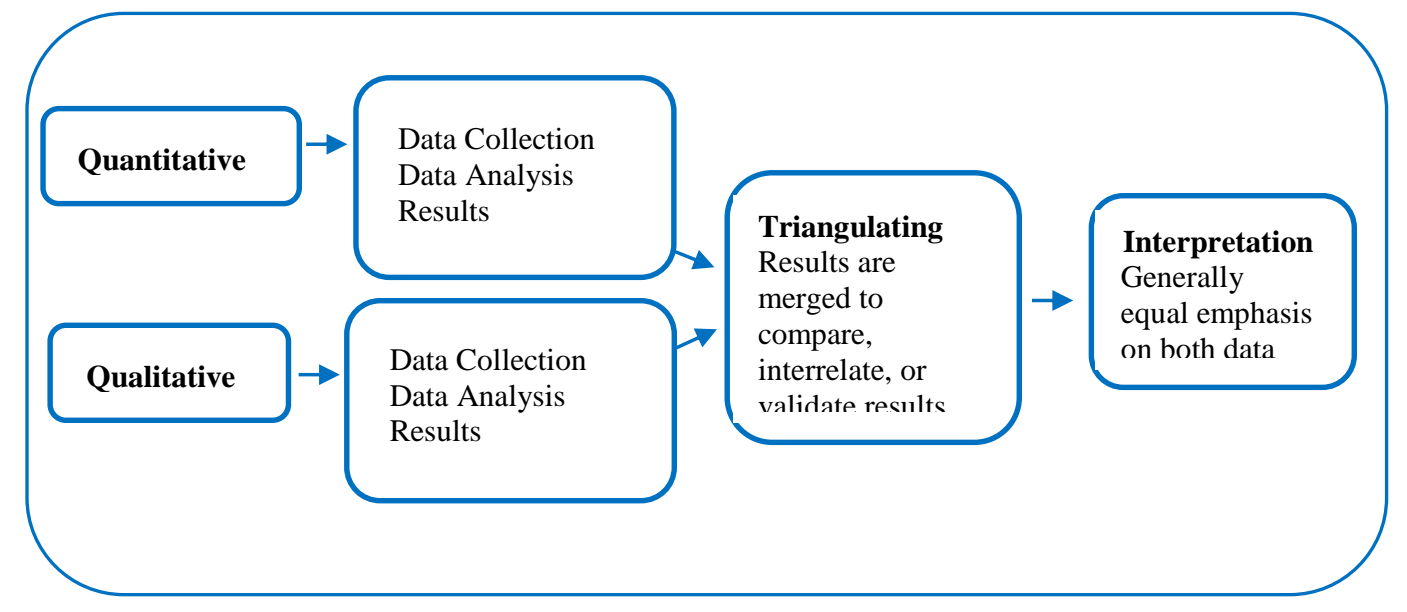

Figure 5.1. The triangulation design in MMR (QUAN+QUAL)

Source: Adapted from Clark, \& Creswell, 2011

\section{Data and Methods}

Qualitative Data. The data for the qualitative research were obtained from the open-ended questions of a semi-structured questionnaire of fifty Mexican immigrants in the Portland and Salem metropolitan areas. I was able to garner maximum participation by providing remuneration of $\$ 10$ to $\$ 15$ per participant in the form of a Starbucks gift card, a culturally sensitive environment, childcare, and friendly scheduling and locations. The interviews provided both the context and processes of civic engagement for this particular sample. As a Mexican national, my access to this population and language skills facilitated data collection.

As part of the participant observation I lived in Beaverton for nine months with a Mexican family and in Woodburn for a summer to become more familiar with the population I was interviewing. Since September 2011 I have volunteered with the Beaverton Hispanic Center, a nonprofit organization that works with the immigrant 
community to address issues of equity and foster engagement in their new communities of residence. Similarly, since 2011 I became a member of Hispanicpros, another nonprofit organization that focuses on promoting business networking and employment opportunities for Latino professionals.

Quantitative Data. The goal of the quantitative analysis in this study was to identify relationships between the patterns of and barriers to civic engagement, and contextual factors including legal status, demographic characteristics, socioeconomic factors and characteristics of the immigrant experience. The closed-ended questions of the semi-structured interview were used in this part of the study.

Purposive sampling is often used in qualitative research and for evaluation (Krathwohl, 2009). Purposive sampling was the most appropriate sampling strategy for this study because 1) the number of Mexicans living in the state is large, approximately 400,000, which comprised 85 percent of the total Hispanic population in Oregon, 2) a large proportion of Mexican immigrants are undocumented and only 10 percent of the adult Mexican population is legal in the state (King et al., 2011), and 3) a small purposive sample may not be representative but still provides a view of the reality of those interviewed which is impactful for this study.

\section{Research Setting}

My fieldwork was located in the metropolitan areas of Salem and Portland, Oregon. Both settings are situated in the upper northwestern region of Oregon, where approximately 12 percent of the population is Latino (The Oregon Community Foundation, 2011), and where nearly 70 percent of Mexicans living in Oregon reside (King et al., 2011). Mexicans are by far the largest group within the Latino population 
(Gonzales-Berry \& Mendoza, 2010; King et al., 2011). In the Salem metropolitan area the Latino population accounts for up to 21.9 percent of the general population (Population Research Center, 2010). In the Portland metropolitan area the Latino population accounts for up to 11.7 percent of the general population (Population Research Center, 2010). The Mexican population in the Salem metropolitan area is primarily from rural Mexican communities, undocumented and with low levels of literacy (U.S. Bureau Census, Instituto Nacional de Estadística Geografía e Informática [National Institute of Statistics and Geography] (INEGI), Consejo Nacional de Población [National Population Council] (CONAPO) and Consulate of Mexico in Portland). In comparison, Mexicans residing in the Portland metropolitan area are from more diverse social classes, including people with higher education and documented status. These heterogeneous demographic characteristics of Oregon's new residents make the metropolitan areas of Salem and Portland interesting research sites since they have the highest concentration of Mexican immigrants residing in the state and incorporate the diversity of the population.

Respondents included people from rural and urban communities, undocumented and documented, with different educational attainment and English speaking skills, as well as various ages, genders, class status, and lengths of time in the United States. This allowed for a comparison of varied civic engagement practices and the impact of those practices, expectations, opportunities, and limitations.

Migrants from Mexico residing in the Salem and Portland metropolitan areas maintain ties with their communities of origin by visiting or speaking on the phone. They commonly send money to provide their communities with electricity, drainage, and drinking water, as well as to reconstruct churches, support community celebrations, 
cement dirt roads and houses; support local candidates; or even by returning to public positions in their communities of origin.

In addition, some are also engaged with their communities of residence in Oregon by joining organizations, supporting political candidates, attending marches and events and volunteering for schools and nonprofit organizations.

\section{Procedures}

Table 5.1 shows a summary of the procedures of this triangulation research study to aid the visualization of data collection, the sequence of analysis and its time line. 
Table 5.1. Triangulation design procedures (QUAN +QUAL)

\begin{tabular}{|c|c|c|c|}
\hline Type & Procedures & Products & $\begin{array}{l}\text { Research } \\
\text { Questions }\end{array}$ \\
\hline $\begin{array}{l}\text { Quantitative and } \\
\text { Qualitative Data } \\
\text { Collection }\end{array}$ & $\begin{array}{l}\text { SPSS quantitative } \\
\text { software } \\
\text { Data screening } \\
\text { Descriptive } \\
\text { Statistics of data } \\
\text { set }\end{array}$ & $\begin{array}{l}\text { Data set that contains } \\
\text { results from the semi- } \\
\text { structured interview } \\
\text { (closed-ended } \\
\text { questions) } \\
\text { Audio recording } \\
\text { Interview transcripts }\end{array}$ & N/A \\
\hline $\begin{array}{l}\text { Answering Research } \\
\text { Questions }\end{array}$ & $\begin{array}{l}\text { SPSS quantitative } \\
\text { software } \\
\text { Frequencies } \\
\text { Correlations }\end{array}$ & $\begin{array}{l}\text { Findings of } \\
\text { quantitative data }\end{array}$ & $\begin{array}{l}\text { Research } \\
\text { Question } \\
\# 1 \text { and } \# 2\end{array}$ \\
\hline $\begin{array}{l}\text { Qualitative Data } \\
\text { Analysis }\end{array}$ & $\begin{array}{l}\text { Reading all notes } \\
\text { from the interviews } \\
\text { and listening to } \\
\text { audio recordings } \\
\text { Manual coding } \\
\text { Coding using } \\
\text { thematic network } \\
\text { analysis }\end{array}$ & $\begin{array}{l}\text { Codes and Themes } \\
\text { Basic, organizing, } \\
\text { and global themes } \\
\text { Similar and different } \\
\text { themes and categories }\end{array}$ & $\begin{array}{l}\text { Research } \\
\text { Question \# } \\
3 \text { to \#5 }\end{array}$ \\
\hline $\begin{array}{l}\text { Integration of the } \\
\text { Quantitative and } \\
\text { Qualitative Results }\end{array}$ & $\begin{array}{l}\text { Interpretation and } \\
\text { explanation of the } \\
\text { quantitative and } \\
\text { qualitative results }\end{array}$ & $\begin{array}{l}\text { Discussion, } \\
\text { Implications } \\
\text { Future Research }\end{array}$ & NA \\
\hline
\end{tabular}

Source: Adapted from Clark, \& Creswell, 2011

\section{Data Sources}

\section{Subject recruitment and sampling design}

The population in the Portland metropolitan area is approximately 11 percent of Latino descent, with Mexicans being the largest component of the Latino population, 
which mirrors the larger Oregon Latino population (U.S. Census, 2010). The Latino population in the Salem metropolitan area accounts for up to 22 percent, making Salem proportionately the most Latino metropolitan area in Oregon. This study is a purposive sample of Mexican immigrants residing in the metropolitan areas of Portland and Salem, Oregon who volunteered to participate in my research.

I advertised my study in St. Cecilia Catholic Church in the city of Beaverton and Saint Luke Catholic Church in the city of Woodburn. The flyers as well as all other materials for the interviews are presented in Appendices A through D. The flyers asked the question "Are you involved in your community?" and provided information on the purpose of the study, my adviser's and my personal contact information, and mention of a $\$ 10.00$ Starbucks gift card. People who were interested called and we scheduled a meeting where I shared the importance and goals of this study. I also contacted people through my former volunteering experience in pro-immigrant organizations and people in hometown associations from southern Mexican states living in Oregon and asked them for more contacts. This "snowball" sampling allowed me to reach out to more immigrants, which provided for a wide range of experiences. In many cases I met with interviewees over coffee or lunch, where I paid the bill. In these cases no gift card was provided. Additionally, a small business owner residing in Woodburn, Oregon, offered her assistance in recruiting Mexican immigrants residing in the Woodburn - Salem metropolitan areas. The boundary on the sample size was saturation, meaning I continued to sample only until no new or relevant data emerged (Bryman, 2006).

I met with 50 participants with the interviews each averaging about 60 minutes. I interviewed all the participants, who signed the informed consent in Spanish. All 
interviews were conducted in Spanish, my native language. The interviews were recorded with a digital voice-recorder and I kept notes during the interviews.

In order to identify differences between recent immigrants and those with lengthier histories in the United States, I sampled Mexican immigrants with varying lengths of stay. Study participants have been in the country between two to 53 years, with an average of sixteen years of residency in the United States.

Data management. All the data sources collected for this study such as transcriptions, original tapes, documents, computer data base, and notes have been maintained in a locked file cabinet in my home office. All files will be maintained for the time period that Portland State University's Institutional Review Board (IRB) committee defined after the completion of this research.

\section{Data Collected}

\section{Interview Design}

Interview questions are divided into three sections. Section one focuses on immigrants' engagement in their communities of origin. This section of the questionnaire adapts the analytical categories focused on everyday economic activities, political activities and sociocultural activities used by Paasche and Fangen (2012) for Mexican immigrants. Section one also integrates the insights of Snel et al. (2006), and recognizes the transnational practices suggested by Portes et al. (2003) (See Tables 4.2 and 4.3 from last Chapter). This widely-used framework appears designed for people with a legal immigration status, a good level of English, and at least modest educational attainment. Therefore, this section has been adapted to more effectively understand the Mexican immigrants in Oregon, as discussed in Chapter 4, augmented by activities conducted by 
documented and undocumented immigrants with a strong participation in local governance in their communities of origin.

Section two includes questions related to changes in Mexican immigrants' engagement in community bridging service, political and social activities in Mexico and in the United States (See Table 5.2). This section asks respondents to indicate if their civic engagement has increased or decreased since they moved to the United States. Lastly, section three is focused on paths and barriers to immigrants' engagement in their communities of residence in Oregon. 
Table 5.2. Changes in bridging service, political and social activities done in Mexico and in the United States

\begin{tabular}{|l|}
\hline \multicolumn{1}{|c|}{ Activities done in Mexico and in the United States } \\
\hline Community Bridging Service \\
Volunteered or completed community service \\
Participated in community fundraiser \\
Donated blood \\
Tutored someone \\
Helped a recent immigrant \\
Helped senior citizens \\
Joined an organization \\
Political \\
Discussed politics with friends or family \\
Used Internet to keep up with current events \\
Read newspaper to keep up with current events \\
Participated in organized demonstrations \\
Officer of an organization \\
Attended a public meeting \\
Social \\
Had friends over to your home \\
Visited neighbors over to their home \\
Visited relatives in person or had them visit you \\
Group Member \\
Attended church or other religious activity \\
Activity \\
Attended family reunions \\
Athletic activities \\
Source: Adapted from Labissere, Reeder \\
\hline
\end{tabular}

Source: Adapted from Labissiere, Reeder Goraczko and Stepick’s (2009).

The three sections correspond to the closed-ended questions, which were later enriched through interview questions about participant's policy priorities and how they decide whether to be engaged in the civic life of Oregon and/or Mexico. 


\section{Data Analysis}

I statistically analyzed the quantitative data, as the preliminary input to further analyze qualitative data.

\section{Quantitative Data Analysis}

This quantitative phase of the study aims to answer research questions 1 and 2:

- How civically engaged are Mexican immigrants in Oregon? Does civic engagement differ by gender, age, indigenous background, economic and legal status, length of time in the U.S., English fluency and education level?

- Does the engagement of immigrants with their home communities detract from engagement in Oregon, or enhance it? Has this relationship changed over time?

I used the Statistical Package for the Social Sciences (SPSS) software for data screening and analysis of civic involvement difference by gender, age, indigenous background, economic and legal status, length of time in the U.S., English fluency and education level (research question \#1). Similarly, to answer Research Question \#2 I used SPSS and Excel to analyze and create categories of levels of civic engagement in Mexican immigrant communities of origin and Oregon. Also, by using Excel, I created summary indexes for bridging service activities, political activities and social activities by summing each individual's participation (bridging service activities, political activities and social activities) and then calculating the mean for each subgroup of gender, age, marital status and length of time in the United States. 
Simple regressions were then performed to check which independent variables impacted economic, political and economic engagement in the United States and in Mexico.

\section{Qualitative Data Analysis}

The qualitative component of this study provides "the perspectives of those being studied - what they see as important and significant" (Bryman, 2006). It is important to understand the processes of Mexican immigrants' civic engagement, allowing for "the possibility of getting at actors' meanings and of concepts emerging out of the data collection" (Bryman, 2006). In this section, I describe the analyses process of the interview questions using a thematic network (Attride-Stirling, 2001) to understand the factors that the participants reported as influencing their paths and barriers to civic engagement in Oregon and in their communities of origin.

Thematic Network Analysis. I followed the step-by-step guide of thematic network analysis (Attride-Stirling, 2001). After transcribing the interviews into Microsoft Word, I coded the data by themes and subthemes to organize them into a graphical representation, namely the thematic network. This thematic network was built in three stages: a) the reduction of the text, b) the exploration of the text, and c) the integration of the exploration (Attride-Stirling, 2001). Figure 5.2 depicts the full process of this threestage thematic network analysis of qualitative data. 


\section{ANALYSIS STAGE A: REDUCTION OR BREAKDOWN OF TEXT}

\section{Step 1. Code Material}

(a) Devise a coding framework

(b) Dissect text into text segments using the coding framework

\section{Step 2. Identify Themes}

(a) Abstract themes from coded text segments

(b) Refine themes

\section{Step 3. Construct Thematic Network}

(a) Arrange themes

(b) Select Basic Themes

(c) Rearrange into organizing themes

(d) Deduce global theme(s)

(e) Illustrate as thematic network(s)

(f) Verify and refine the network(s)

\section{ANALYSIS STAGE B: EXPLORATION OF TEXT}

Step 4. Describe and Explore Thematic Networks

(a) Describe the network

(b) Explore the network

\section{Steps 5. Summarize Thematic Networks}

\section{Figure 5.2. Steps in analyses of thematic networks based on Attride-Stirling, (2001)}

Stage A: The reduction of the text or breakdown. I spent 20-30 minutes

debriefing and writing my reflections about participants' reactions during the interview. I personally transcribed the 50 audio participants' interviews, keeping literal statements (Merriam, 2009). However, only the answers to the following open-ended questions were fully transcribed:

Q1: Have you volunteered in the United States? If yes, Q2, if not Q3.

Q2: Tell me about your experience volunteering at that organization?

Q3: What influenced you to be engaged or volunteer at certain organizations? 
Q4: What do you like the most about engaging with your community of residence?

Q5: Do you know, which organizations in Oregon do more for the well-being of the immigrant population?

Q6: Tell me more about your experience with pro-immigrant organizations?

Q7: What are the factors that prevent you from engaging with your community of residence?

I wrote notes on the margins while reading the transcripts on issues that arose from the text and highlighted statements, phrases or words that seemed essential to answering research questions \# 3 to \#5.

Code material. The coding enabled me to link the respondents' direct quotes with my own analytical notes and observations from previous participant observation. This coding contributed to the rich context of performing a qualitative study by bracketing text and writing observations and responses (Creswell, 2014; Walsh, 2003). The coding framework was created from the recurrent issues in the text (Attride-Stirling, 2001). I also used Word and Excel as tools to organize data and classify respondents' civic engagement and contextual factors by selecting significant quotes.

Identify Themes. Once the text was coded, I went back to the highlighted text and extracted the significant themes. This part of the process allowed me to identify recurrent issues across participants, observing common answers and categories to depict 
similarities and differences among civic engagement paths and barriers. I identified significant themes and grouped them based on their similarities.

Construct Thematic Network. The purpose of creating this network was to work inwards toward a Global Theme (Attride-Stirling (2001). Basic themes (central notions) were identified and extracted. Then categories of these themes were grouped together to summarize "the underlying story they are telling" (Attride-Stirling, 2001), and these were identified as Organizing Themes. Finally, the Organizing Themes were put together in line with the basic themes, to illustrate a Global Theme (See Figure 5.3). Global Themes are macro topics that represent an argument about a given situation. The objective of this organizational structure was to develop a tool to summarize and illustrate the themes for the interpretation process. 


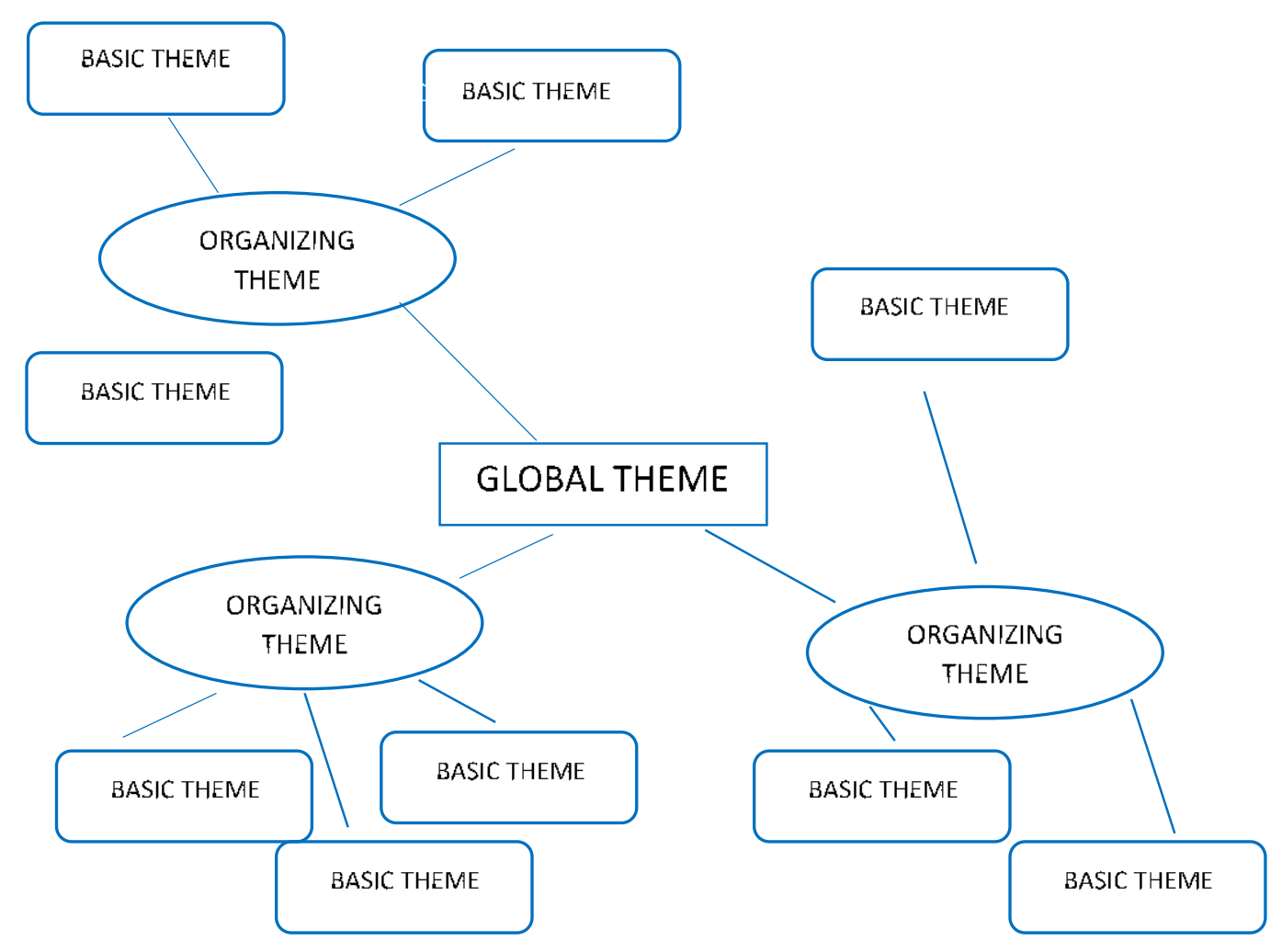

Figure 5.3. Example of thematic network analysis, based on Attride-Stirling (2001)

Stage B: The exploration of the text. This step included the exploration and description of the networks created. I went back to the original text based on the Global Themes, Organizing Themes and Basic Themes in order to look for an interpretation and understanding of the whole material (Attride-Stirling, 2001).

Stage C: The integration of the exploration. In this final step, I interpreted the patterns in the data in the interviews. These final stages (B and C) are part of the analysis of the thematic network that I present in chapter five. Additionally, at this point, I 
integrated the quantitative analysis with the qualitative data to interpret the results of the analyses together.

\section{Participant Observation}

Participant observation was carried out while attending hometown association meetings, pro-immigrant organization meetings, festivals such as "Fiesta Mexicana" in Woodburn and the "Feria de Salem", masses at different churches with services in Spanish, as well as in the waiting room of the Mexican Consulate. Observation also occurred while living and socializing with immigrant communities and during my volunteer work with the Beaverton Hispanic Center, a pro-immigrant organization. Participant observation data was gathered in these ways: general observations during activities that I was engaged in as part of this research, direct observations of meetings, and by listening to conversations that residents in these communities had about their political and social activities. When attending the meetings, I took running notes and reviewed them afterwards in order to make observations. At the end of the day, to better organize my field notes (Brayman, 2006), I recorded the time of the day, the location, and the people involved in the observation. Participation observant helped to complement the study, especially attendance of hometown association meetings as well as religious and social events.

\section{Limitations}

Participant observation and qualitative interviews are subjective in nature. Arguments can be made that qualitative results only apply to particular settings and thus are not generalizable (Brayman, 2006; Creswell, 2014). However, the qualitative approach provided in this study relied on quantitative data as well, which increased the 
study's reliability. While this research may not generalize beyond the particular cities of Salem and Portland, or the State of Oregon, this study adds to its field of research by analyzing a new population, with demographic characteristics that have not previously been studied in Oregon. This research expands the analytic framework of the literature because of the unique characteristics of Mexican population in Oregon: many lack legal status and come from rural communities. This study may provide important direction, raise essential questions, and suggest an approach to develop more comprehensive methods for engaging Mexican immigrants in their US communities of residence.

\section{Trustworthiness}

According to Ulin et al. (2005) studies should reflect as accurately as possible the participants' perspectives and experiences (p. 26). In addition to my own membership in the community of research, my former participant observation in meetings, previous volunteer work, and previous work on research projects, the following criteria were set in the present study to make the data credible, confirmable, dependable, and transferable: 1) the original study population would co-participate in the research. At the end of the study I shared fragments of the findings with key participants (leaders from those communities of study) to solicit their opinion about the accuracy of the results. 2) every research project is unique; however, this study attempted to provide comparable data collection protocols that can be used in future studies. 


\section{Chapter 6 Research Results}

The semi-structured interview provided a rich dataset with which to understand the nature of Mexican immigrants' civic engagement in Oregon and in their communities of origin. Findings were organized under three major headings of data analysis: a) Mexican immigrants' transnational civic engagement, b) changes in Mexican immigrants' civic engagement with communities of origin and in Oregon and c) paths and barriers to Mexican immigrant civic engagement in Oregon.

First, the quantitative and qualitative data results helped illuminate the following research questions:

1. How civically engaged are Mexican immigrants in Oregon? Does civic engagement differ by gender, age, indigenous background, economic and legal status, length of time in the U.S., English fluency and education level?

2. Does the engagement of immigrants with their home communities detract from engagement in Oregon, or enhance it? Has this relationship changed over time?

Third, I present the interpretation of the data results from the qualitative phase to express specific findings associated with research questions 3 to 5 .

3. What are the issues with which participants are most often engaged in their communities of residence?

4. What are the barriers that most deter participants from civic engagement in their communities of residence?

5. Which organizations do this group of immigrants work with on civic issues? How? 


\section{Mexican Immigrants' Transnational Civic Engagement}

This section presents an analysis of the relationship between civic engagement and variables such as gender, age, indigenous background, economic and legal status, length of time in the United States, English fluency, and educational level. With descriptive statistics and simple regression analysis, this data quantitatively addresses research question 2 , whether civic engagement with their home communities detracts from or benefits migrants' engagement with their communities of residence.

It is clear that "many contemporary migrants maintain economic, social, and political ties (Paasche \& Fangen, 2012) to their homeland while they are simultaneously incorporated into the countries that receive them" (Levitt \& Jaworsky, 2007; Paasche \& Fangen, 2012).

However, as Guarnizo, Portes, and Haller (2003) observe, "the number of immigrants who are regularly involved in cross-border activism in relatively small." While many Mexican immigrants residing in Oregon are from rural and indigenous communities in southern Mexico, some have learned to mutually assist their fellownationals in their communities of origin and their communities in Oregon. It is also clear that the social and political situation in Mexico influences Mexican immigrants in the United States and they remain informed and involved in the Mexican national political system as well as in US society.

\section{Economic activities in Mexico.}

A major reason people emigrate is to address economic and financial needs of the family. Households in migrants' home villages spend a majority of the remittances they receive to support basic needs such as everyday consumption expenditures. The remaining 
remittance money received is most commonly devoted to the education of migrants' children (Orozco, 2003).

Eighty percent of survey respondents sent money to Mexico on a regular basis. The majority of the people who sent money stated that they sent more money before the recession in 2008, when many lost their jobs or were given fewer hours of work and were forced to decrease the amount of money sent to Mexico. Immigrants also stopped sending money or sent it less often after their parents died and they were left with no immediate family in Mexico. (See Figure 6.1.).

25

20

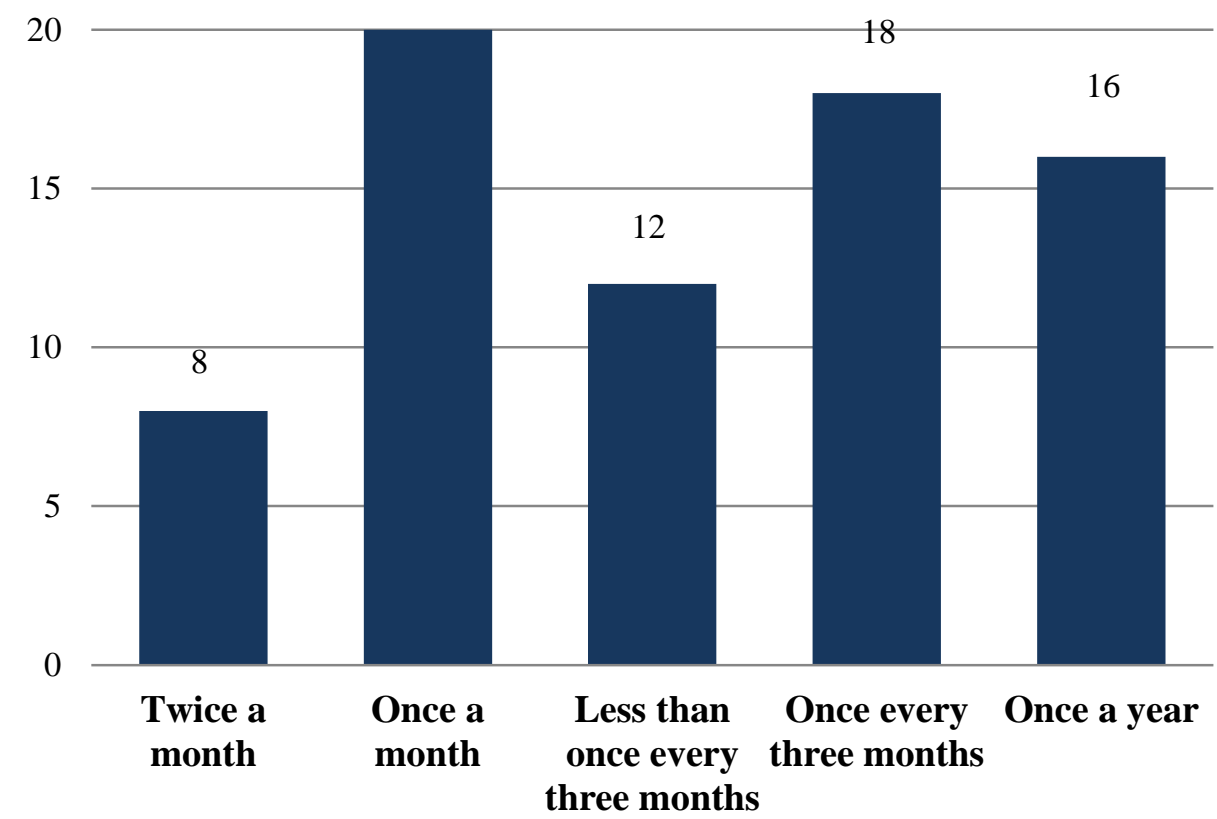

Figure 6.1. How often do you send money to Mexico?

Consistent with the literature (Orozco, 2003; Reyes-Morales \& Gijón Cruz, 2007), 54 percent of respondents in this study sent money to their family in Mexico for 
living expenses, 63 percent for health care expenses, and 36 percent for education. Those participants who sent money for health purposes stated that it is primarily for their parents and grandparents. Similarly, the money for educational purposes was for their children, siblings, nieces, and nephews' education. Improving educational opportunities for people remaining in Mexico is beneficial for both the household and the nation, since it creates more employment opportunities for the individuals attaining higher education levels, and Mexico gains more productive and educated citizens. (See Figure 6.2.)

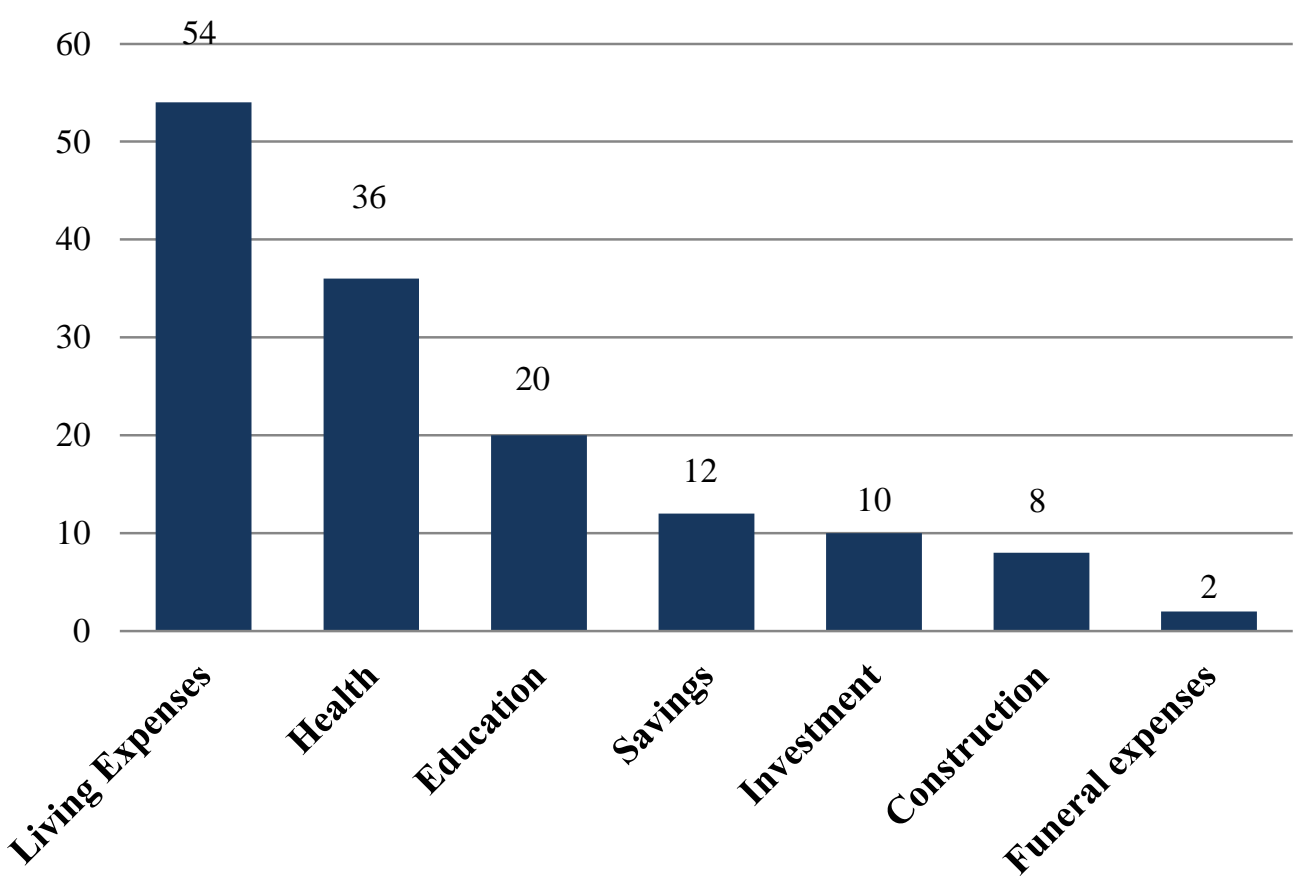

Figure 6.2. Do you know for what the money is used?

Gender plays an important role in studies of transnationalism: in previous studies, women who left their home country with children sent more money home than women who did not leave with her children. Also studies showed that men tended to send less 
money than women (Preston, Kobayashi \& Man, 2006; Wong, 2003). In this study, more men send money for living expenses, however, more women send money to support their children and siblings.

In general, respondents with higher economic engagement in Mexico were people who spoke an indigenous language $\left(\mathrm{r}=0.31, \chi^{2}=10.94\right)$, were older $\left(\mathrm{r}=0.42, \chi^{2}=20.14\right)$, had fewer years of education $\left(r=-0.26, \chi^{2}=19.04\right)$, were men rather than women $(r=-$ $.0 .29)$, and came from a rural background. $\left(\chi^{2}=8.93\right)$. The length of time in the US, legal status, and income did not have any significant influence on economic engagement in Mexico. The finding that those with an indigenous background tend to be more engaged in economically supporting the development of their communities of origin is consistent with the literature (Martínez Nateras \& Stanley, 2009; Stephen, 2007).

Table 6.1. Economic engagement in Mexico

\begin{tabular}{|c|c|c|c|c|c|}
\hline $\begin{array}{l}\text { Dependent } \\
\text { Variable }\end{array}$ & Independent Variables & $\begin{array}{l}\text { Chi } \\
\text { Square }\end{array}$ & $\begin{array}{c}\text { Sig }(p \\
\text { Value })\end{array}$ & $\begin{array}{l}\text { Spearman's } \\
\text { Correlation } \\
\text { Coefficient }\end{array}$ & $\begin{array}{l}\text { Sig }(p \\
\text { Value })\end{array}$ \\
\hline \multirow{8}{*}{$\begin{array}{l}\text { Economic } \\
\text { Engagement } \\
\text { in Mexico } \\
\text { (ECOMEX) }\end{array}$} & Age $(<25,25-40,41-60,>60)$ & 20.14 & 0.02 & 0.42 & 0.002 \\
\hline & $\begin{array}{l}\text { Years of education }(<9,10-15, \\
16-19,>20)\end{array}$ & 19.04 & 0.03 & -0.26 & 0.07 \\
\hline & $\begin{array}{l}\text { Length of time in US }(<10,10- \\
20,21-30,>30)\end{array}$ & 2.36 & 0.98 & -0.27 & 0.85 \\
\hline & Gender $(1=\mathrm{M}, 2=\mathrm{F})$ & 5.17 & 0.16 & -0.29 & 0.04 \\
\hline & $\begin{array}{l}\text { Speaks indigenous language } \\
(0=\text { No, } 1=\text { Yes })\end{array}$ & 10.94 & 0.01 & 0.31 & 0.03 \\
\hline & Legal status $(0=$ No, $1=$ Yes $)$ & 1.93 & 0.59 & -0.08 & 0.60 \\
\hline & $\begin{array}{l}\text { Income }(<30000,30-50 \mathrm{~K}, \\
>50000)\end{array}$ & 10.76 & 0.1 & 0.07 & 0.62 \\
\hline & $\begin{array}{l}\text { Urban or rural }(0=\text { rural, } \\
1=\text { urban })\end{array}$ & 8.93 & 0.03 & -0.19 & 0.19 \\
\hline
\end{tabular}

Source: Lopez-Salinas, unpublished data 2016 
In addition to frequent regular remittances, Mexican immigrants in the United States send special, out-of-the-ordinary remittances to solve critical situations and unforeseen circumstances (Canales-Cerón, 2008; Juárez Martínez et al., 2002). Birthdays and celebrations, as well as the possibility of illness among family members and relatives, occasionally call for special remittances. Recipients save to offset the costs of risks such as accidents or diseases, while others who use the savings to fund special events like baptisms, graduations, "fifteen-year parties" or quinceañera parties, weddings, funerals, and traditional towns' celebrations. Other immigrant families channel part of their savings to productive investments in tools, machinery, building a well or opening a business, and buying houses and/or land.

Surprisingly, almost half of the Mexican residents of Oregon surveyed have purchased houses and land in Mexico. Those who do not have legal residence in the US are more likely to acquire property in Mexico. Nevertheless, most of people interviewed for this study stated that approximately 80 percent of their income is spent in the United States.

\section{Political activities in Mexico}

For the purposes of this research, the four dimensions of Snel, Engbersen and Leerkes (2006) in addition to Boccagni's (2012) dimensions on "transnational politics" are analyzed here: "reading newspapers from the country of origin," "keeping in touch with politics in the country of origin", "being a member of a political party in the country of origin," "giving money to a political party", "participating in demonstrations related to the country of origin" (Snel, Engbersen \& Leerkes, 2006), and "distance voting" (Boccagni, 2012). 
Although study participants have some kind of understanding about the general state of political affairs in Mexico, none demonstrated interest in civic participation in the form of political party membership or giving money to a political party in Mexico. However, participants reported reading newspapers from Mexico and staying informed about current Mexican politics. Figure 6.3. shows that 64 percent of the people interested in Mexican news get their news through TV, 50 percent through the internet and 32 percent through family members living in Mexico. Only six percent get their news from the radio. Univision is the most frequent TV channel watched by respondents, followed by Telemundo and Canal 11 (Mexican TV Channel broadcasted by IPN, National Polytechnic Institute). Interviewees also stated that they use the internet to keep updated on Mexican politics mostly through Facebook and online newspapers such as La Jornada, Aristegui noticias, Excelsior, and sinembargo.mx.

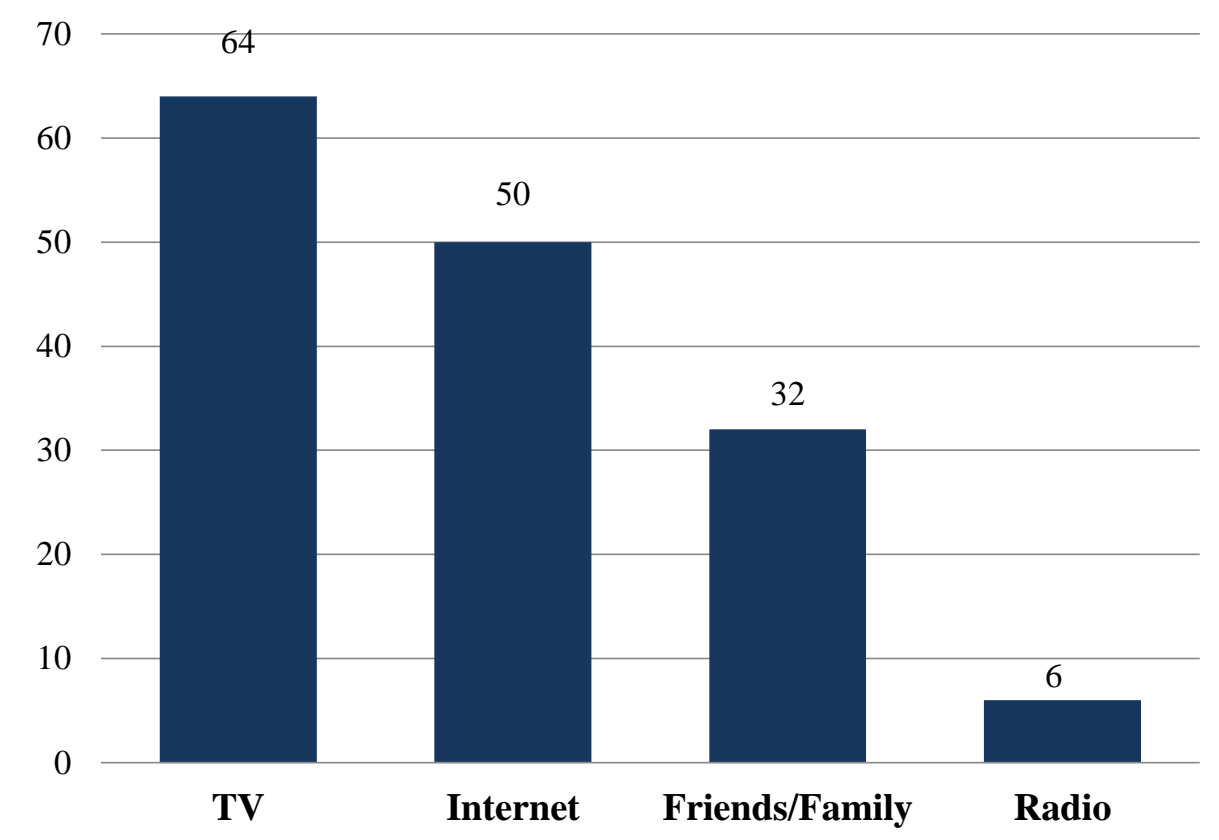

Figure 6.3. How do you get news related to Mexico? 
In general, study participants' political engagement in Mexico is not influenced by any independent variable as seen in the following table.

Table 6.2. Political engagement in Mexico

\begin{tabular}{|c|c|c|c|c|c|}
\hline $\begin{array}{l}\text { Dependent } \\
\text { Variable }\end{array}$ & Independent Variables & $\begin{array}{l}\text { Chi } \\
\text { Square }\end{array}$ & $\begin{array}{l}\text { Sig (p } \\
\text { Value) }\end{array}$ & $\begin{array}{l}\text { Spearman's } \\
\text { Correlation } \\
\text { Coefficient }\end{array}$ & $\begin{array}{c}\text { Sig (p } \\
\text { Value) }\end{array}$ \\
\hline \multirow{8}{*}{$\begin{array}{l}\text { Political } \\
\text { Engagement } \\
\text { in Mexico } \\
\text { (POLMEX) }\end{array}$} & $\begin{array}{l}\text { Age }(<25,25-40,41- \\
60,>60)\end{array}$ & 9.24 & 0.68 & 0.24 & 0.1 \\
\hline & $\begin{array}{l}\text { Years of education }(<9, \\
10-15,16-19,>20)\end{array}$ & 13.51 & 0.33 & -0.04 & 0.79 \\
\hline & $\begin{array}{l}\text { Length of time in US } \\
(<10,10-20,21-30,>30)\end{array}$ & 5.32 & 0.95 & 0.06 & 0.70 \\
\hline & Gender $(1=\mathrm{M}, 2=\mathrm{F})$ & 0.86 & 0.93 & 0.06 & 0.67 \\
\hline & $\begin{array}{l}\text { Speaks indigenous } \\
\text { language }(0=\mathrm{No}, 1=\mathrm{Yes})\end{array}$ & 7.18 & 0.13 & 0.14 & 0.33 \\
\hline & $\begin{array}{l}\text { Legal status }(0=\text { No, } \\
1=\text { Yes })\end{array}$ & 0.89 & 0.93 & -0.03 & 0.85 \\
\hline & $\begin{array}{l}\text { Income }(<30000,30- \\
50 \mathrm{~K},>50000)\end{array}$ & 10.32 & 0.24 & 0.09 & 0.57 \\
\hline & $\begin{array}{l}\text { Urban or rural }(0=\text { rural, } \\
1=\text { urban })\end{array}$ & 1.98 & 0.74 & 0.18 & 0.21 \\
\hline
\end{tabular}

Source: Lopez-Salinas, unpublished data 2016

I asked participants to rank the issues in Mexico that would be most important in deciding whether or not to return permanently to Mexico. The results were: education (72 percent), employment (66 percent), and security, including corruption and violence (56 percent) as the most important policies for the interviewees. Study participants stated that the Mexican government should provide more education and employment opportunities so that young Mexicans do not have to come to the US to look for work. Policies aiming to increase security and decrease drug trafficking are also important determinants in participants' decision to return to Mexico. Interviewees proposed that the Mexican government should implement policies that allow low income people to borrow money to 
open and sustain small business so that citizens can support themselves and their families in Mexico instead of migrating to the United States.

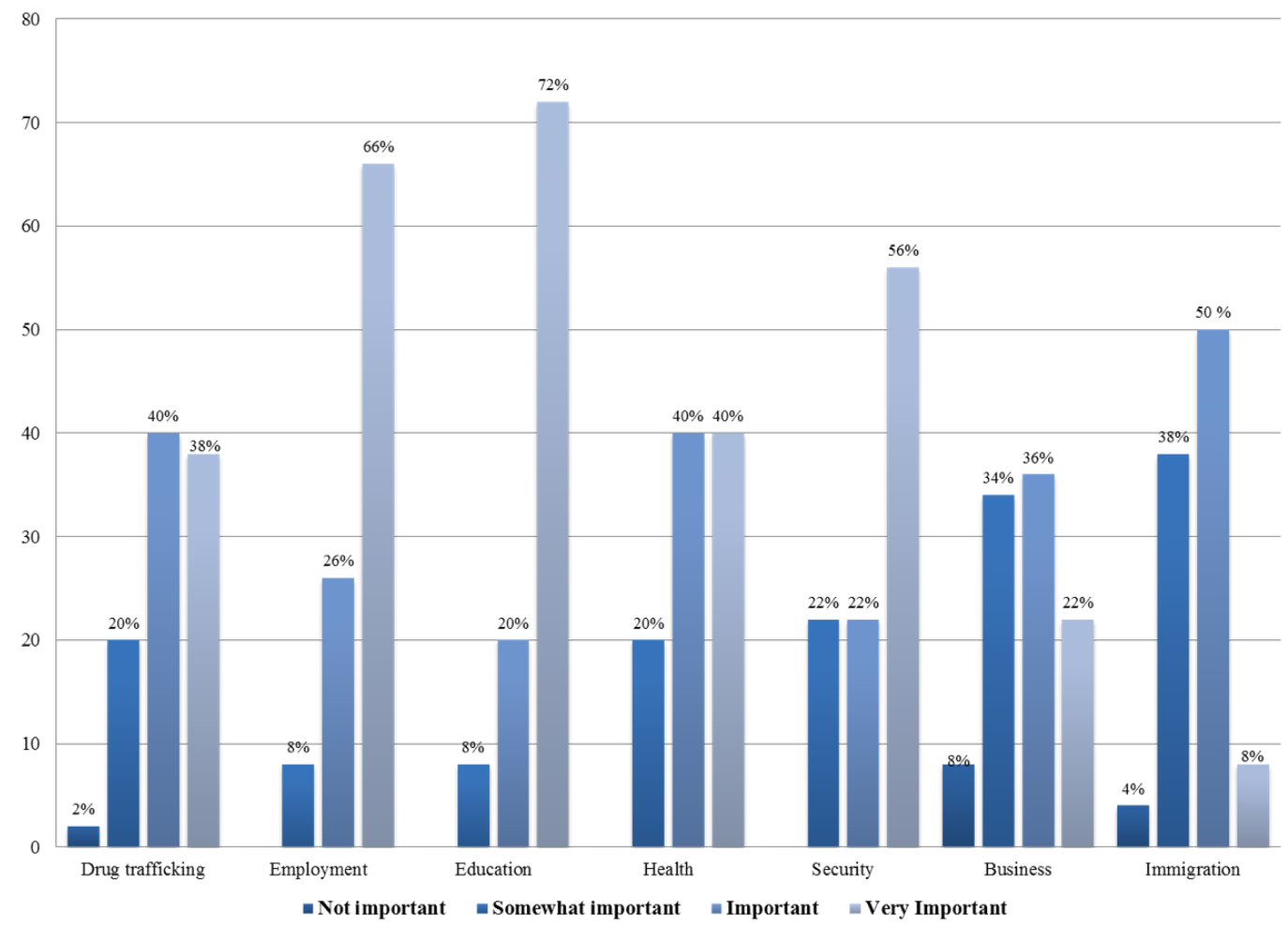

Figure 6.4. Public policy issue you feel is the most important in Mexico

\section{According to Paasche and Fangen (2012), "knowledge of country-of-origin}

politics is an identity marker and keeping in touch with politics in the country of origin may make it easier to get in touch with compatriots in the country of residence." Martha, an immigrant from Distrito Federal who has been in the United States for thirteen years, stated that her political engagement in both Mexico as well as US was catalyzed when she learned about the "Mexican government's atrocities to our people in Atenco ${ }^{3}$. After

\footnotetext{
${ }^{3}$ On May 3 2006, inspectors and municipal police of Texcoco, State of Mexico, tried to relocate the flower sellers at the municipal market. The merchants did not accept displacement and called for the support for the people of Atenco, known as the People's Front in Defense of the Land (Frente de Pueblos en Defensa de la Tierra). This group established a public profile through their fight against the government's plan to
} 
these events, I started to dig more and more about why our Mexico is the way it is and what I could do as a citizen to change it. Now I not only coordinate a radio station where we inform people about the political situation in Mexico but also have invited people not to be afraid and take the streets to demanding driver's licenses for undocumented people" (Female, DF, undocumented, worker in cleaning services).

\section{Socio cultural activities in Mexico}

Three categories concerning social activities in interviewee's country of residence were considered in this research: a) membership in an organization related to the country of origin, b) attendance at meetings with primarily compatriots, and c) visit to cultural events in the country of origin.

Thirty eight percent of those interviewed were members of an organization related to their country of origin and 58 percent attended meetings primarily with compatriots. This is especially true for participants from rural backgrounds. However, none of the interviewees have visited their country of origin for cultural events since they came to the U.S.; primarily due to lack of legal documents and/or the fact that their entire nuclear family resides in the U.S. Although people may not have visited Mexico since they came to the United States, they have maintained their social ties with their families and communities of origin in Mexico.

\footnotetext{
keep their land to build the new international airport outside Mexico City. The arrival of the people of Atenco was repelled by the local police, forcing them take refuge in a warehouse. The police took 84 prisoners. As a response, the people of Atenco blocked a highway, confronting police and detaining Mexico state officials to force authorities to release detainees.

According to data from the National Human Rights Commission of Mexico, on May 4 in a joint operation involving 700 elements of the Federal Preventive Police and 1,815 of the State Security Agency $(2,515$ total), government officials occupied and repressed the town of Atenco. Two people were killed, 206 people were tortured and injured, and assaults and rapes against women were reported (Martín, 2012).
} 
This dataset showed that immigrants who are more socially engaged in Mexico are those with fewer years of education $\left(r=-0.47, \chi^{2}=20.1\right)$, who speak an indigenous language $\left(\mathrm{r}=0.38, \chi^{2}=9.87\right)$, and have not acquired legal status in the United States $(\mathrm{r}=$ 0.32, $\chi^{2}=8.62$ ). According to this study, age, gender, time in the United States, income, and urban versus rural background do not significantly influence social engagement in Mexico. (See Table 6.3.).

Table 6.3. Social engagement in Mexico

\begin{tabular}{|c|c|c|c|c|c|}
\hline $\begin{array}{l}\text { Dependent } \\
\text { Variable }\end{array}$ & Independent Variables & $\begin{array}{l}\text { Chi } \\
\text { Square }\end{array}$ & $\begin{array}{l}\text { Sig }(p \\
\text { Value })\end{array}$ & $\begin{array}{l}\text { Spearman's } \\
\text { Correlation } \\
\text { Coefficient }\end{array}$ & $\begin{array}{l}\text { Sig }(p \\
\text { Value })\end{array}$ \\
\hline \multirow{8}{*}{$\begin{array}{l}\text { Social } \\
\text { Engagement } \\
\text { in Mexico } \\
\text { (SOCIOMEX) }\end{array}$} & Age $(<25,25-40,41-60,>60)$ & 15.61 & 0.08 & 0.21 & 0.14 \\
\hline & $\begin{array}{l}\text { Years of education }(<9,10- \\
15,16-19,>20)\end{array}$ & 20.1 & 0.02 & -0.47 & 0.001 \\
\hline & $\begin{array}{l}\text { Length of time in U.S. }(<10, \\
10-20,21-30,>30)\end{array}$ & 16.46 & 0.06 & 0.199 & 0.17 \\
\hline & Gender $(1=\mathrm{M}, 2=\mathrm{F})$ & 3.62 & 0.31 & 0.156 & 0.28 \\
\hline & $\begin{array}{l}\text { Speaks indigenous language } \\
(0=\mathrm{No}, 1=\text { Yes })\end{array}$ & 9.87 & 0.02 & 0.38 & 0.01 \\
\hline & Legal status $(0=$ No, $1=$ Yes $)$ & 8.62 & 0.04 & -0.32 & 0.03 \\
\hline & $\begin{array}{l}\text { Income }(<30000,30- \\
50 \mathrm{~K},>50000)\end{array}$ & 4.66 & 0.32 & -0.236 & 0.11 \\
\hline & $\begin{array}{l}\text { Urban or rural }(0=\text { rural, } \\
1=\text { urban })\end{array}$ & 6.28 & 0.1 & -0.28 & 0.06 \\
\hline
\end{tabular}

Source: Lopez-Salinas, unpublished data 2016

This research is not able to explore the in-depth impact of generation on civic engagement because only first generation immigrants were interviewed. Nevertheless, I witnessed that indeed, those who have not had the opportunity to visit Mexico since arriving in the United States feel the need to share time and life experiences with people from the same village, town or region. Also, interviewees have recreated their religious and social customs native to their regions of origin, and these practices are transmitted to their children. Those immigrants with greater financial resources and/or legal status in the 
United States have ensured that their children know their home communities and sometimes send them for a couple of months during the summer to become familiar with their social and family traditions in Mexico.

Elia, a permanent resident who has been in the United States for over 20 years, states the importance of sending her two children to Mexico every summer, so "they know where they come from and do not struggle with identity issues" (Female, Michoacán, permanent resident, housewife). She also stated that even though she travels back and forth from the United States, summer is a difficult time because there are a lot of job opportunities in Oregon and sometimes she skips going to Mexico during the summer since her sister in Mexico takes care of her children. However, Elia said that she tries to visit her home in her rural community every January when they celebrate their religious festivities.

\section{Economic activities in Oregon}

Research suggests that far from the assertion that immigrants drain U.S. resources, "immigrants enhance the economic, educational and civic development of this country" (Nevarez, 2015; Núñez, 2015). Immigrants from all nationalities have contributed to the U.S. economy in through volunteering, paying taxes, opening small businesses, start-ups, and holding international patents (Núñez, 2015). Contrary to common assumptions, scholars have suggested that even undocumented immigrants contribute to the U.S. economy in various ways, including paying taxes which are often deducted from their wages and never claimed. Immigrants have also contributed to the opening of small businesses that create jobs for others (Becerra et al., 2012; Núñez, 2015). 
Today, Mexicans represent around six percent of the Oregon workforce. The majority are employed in service occupations, followed by natural resources, construction, and maintenance. A smaller percentage of workers are concentrated in sales and office occupations, as well as management, science, and arts (CAUSA, 2012; King, et al., 2011). Mexicans in Oregon make up to 60 percent of the workforce in farming, fishing, and forestry occupations. The agriculture industry in Oregon is a $\$ 4$ billion dollar industry. Immigrants have greatly contributed to the growth of the Oregon agriculture industry in an increasingly competitive and globalized economy. Overall, immigrants' jobs and contributions to the State have been essential not only to the trades and agriculture, but also to the overall economic wellbeing of Oregon communities.

Latinos have also contributed to Oregon's economy by opening businesses. There are about 12,000 Latino businesses in Oregon. Most are small businesses, but in 2007 they contributed $\$ 1,663,452,000$ (CAUSA, 2012) to Oregon's economy. The purchasing power of Latinos in the state has also become more visible, especially the increase in the number of Latinos who own homes. From 2000 to 2010, the number of Latino homeowners increased by almost 90 percent (CAUSA, 2012).

For the purpose of this research, economic engagement in the receiving society was measured by: a) owning a house in Oregon, b) contributing to charities in Oregon, and c) investing in businesses in Oregon. Thirty six percent of interviewees stated that they own houses in the US, and 10 percent of study participants were business owners. Immigrants with higher economic engagement in the United States were those with higher proficiency in spoken English $\left(r=0.37, \chi^{2}=16.97\right)$, higher income $(r=0.29)$, legal status acquisition $(\mathrm{r}=0.32)$, and did not speak an indigenous language $(\mathrm{r}=-0.28)$. Other 
factors such as age, years of education, length of time in the U.S., gender, and urban versus rural background had no significant influence in participants' economic engagement in the U.S. (See Table 6.4.). Additionally, using Paasche and Fangen's (2012) framework, we see that in this study, 62 percent of the people interviewed stated they work full time and 76 percent pay taxes on a regular basis, which are also important determinants of immigrant economic engagement (CAUSA, 2012).

Table 6.4. Economic engagement in the United States

\begin{tabular}{|l|l|l|l|l|l|}
\hline $\begin{array}{c}\text { Dependent } \\
\text { Variable }\end{array}$ & Independent Variables & $\begin{array}{c}\text { Chi } \\
\text { Square }\end{array}$ & $\begin{array}{c}\text { Sig (p } \\
\text { Value) }\end{array}$ & $\begin{array}{c}\text { Spearman's } \\
\text { Correlation } \\
\text { Coefficient }\end{array}$ & $\begin{array}{c}\text { Sig (p } \\
\text { Value) }\end{array}$ \\
\hline \multirow{5}{*}{$\begin{array}{l}\text { Economic } \\
\text { Engagement } \\
\text { in the USA } \\
\text { (ECOUS) }\end{array}$} & $\begin{array}{l}\text { Age }(<25,25-40,41- \\
60,>60)\end{array}$ & 6.68 & 0.67 & 0.18 & 0.21 \\
\cline { 2 - 6 } & $\begin{array}{l}\text { Years of education (<9, } \\
10-15,16-19,>20)\end{array}$ & 9.42 & 0.4 & 0.25 & 0.08 \\
\cline { 2 - 6 } & $\begin{array}{l}\text { Length of time in U.S. } \\
(<10,10-20,21-30,>30)\end{array}$ & 9.51 & 0.4 & 0.25 & 0.08 \\
\cline { 2 - 6 } & $\begin{array}{l}\text { Gender (1=M, 2=F) } \\
\text { Speaks indigenous } \\
\text { language (0=No, 1=Yes) }\end{array}$ & 3.5 & 0.32 & 0.09 & 0.52 \\
\cline { 2 - 6 } & $\begin{array}{l}\text { Legal status (0=No, } \\
\text { 1=Yes) }\end{array}$ & 6.79 & 0.08 & -0.28 & 0.05 \\
\cline { 2 - 6 } & $\begin{array}{l}\text { Income (<30000, 30- } \\
\text { 50K, }>50000)\end{array}$ & 7.73 & 0.26 & 0.29 & 0.02 \\
\cline { 2 - 6 } & $\begin{array}{l}\text { Urban or rural (0=rural, } \\
\text { 1=urban) }\end{array}$ & 2.39 & 0.5 & 0.15 & 0.31 \\
\cline { 2 - 6 } & $\begin{array}{l}\text { Proficiency in spoken } \\
\text { English (1-poor, 2-gets by, } \\
\text { 3-good, 4-excellent) }\end{array}$ & 16.97 & 0.05 & 0.37 & 0.008 \\
\hline
\end{tabular}

Source: Lopez-Salinas, unpublished data 2016

Economic engagement would be higher if Mexican immigrants could more readily transfer their education and work qualifications to jobs in the US. Almost none of the interviewees with academic credentials from Mexico were able to get their credentials recognized in the United States. This negative impact is compounded by the fact that some of these individuals may possess inadequate language skills. Even for those who 
attend community college in the United States and obtain their diploma, the possibilities to go to college were diminished because of how expensive it is and because legal documents were required to attend college in Oregon before 2013 (Zheng, 2013). Similarly, for those without legal status, even if they have a GED (General Educational Development) diploma, the possibility of getting a better job was lower due to lack of a Social Security number.

\section{Political activities in Oregon}

Political engagement includes registering to vote, voting in an election, and volunteering for a political party. Participants were asked if they have participated in any of these activities in the last five years. Additionally, participants' political engagement was measured by membership in PCUN and CAUSA, the largest Latino political organizations in Oregon. Table 6.5. displays the descriptive statistics for formal political civic activities. A change in behavior is apparent: among the nine naturalized citizens, seven have voted in an election. Similarly, among the naturalized US citizens only one person is not registered to vote. Only one person has volunteered time to a political party.

Table 6.5. Percentage of formal political activities

\begin{tabular}{|lrr|}
\hline \multicolumn{1}{|c}{ Question } & Yes & \multicolumn{1}{c|}{ No } \\
Are you registered to vote? & 88.88 & 11.11 \\
Have you voted in a US election in the past two years? & 77.7 & 22.3 \\
Have you worked as a volunteer for a political party or candidate in the last two years? & 11.11 & 88.88 \\
\hline
\end{tabular}

Approximately, 30,000 to 40,000 Latinos are turning eighteen every month in the United States. The eligible voting population is growing, but literature suggests that in 
general people do not vote because they do not see that politicians represent their interests.

Previous research suggests that voting is usually an important variable in the discussion of an individuals' civic engagement (Dudley \& Gitelson, 2002). This study reveals that among the seven naturalized citizens, 89 percent are registered to vote and 77 percent have cast ballot in the last two years. These results align with other studies which have found that over time people tend to increase their voting rates, attendance at political meetings, and involvement with organizations (Black, 1987). This increase is largely due to the fact that people may obtain legal status and/or become more familiar with the political landscape of their communities of residence the longer they reside in the U.S. (Black, 1987).

In a separate study for which I interviewed 20 Mexican immigrants residing in the city of Woodburn, Oregon, the results were somewhat different. Woodburn is a rural town where almost 60 percent of the population is of Mexican origin. A large proportion of the interviewees have low educational attainment, come from rural communities, are green card holders, and have been in the U.S. for over fifteen years. However, many do not understand how to become a U.S. citizen and think that permanent residency is preferable to naturalization. Many interviewees prefer to not be in contact with public institutions in order to remain safe and guard against exposure which could risk deportation. In other words, some interviewees prefer not to be visible, even when they have a legal immigration status and have been in the United States for over ten years. This is especially true for those who do not speak English and do not typically spend time with people from different cultural backgrounds. 
It is also true that first generation immigrants tend to be more concerned about their primary needs such as housing, food, and settlement issues rather than political issues (Curiel, 2007; DeSipio, 2006; Suarez-Orozco \& Suárez-Orozco, 1995). In fact, second generation immigrants tend to be more politically involved than their immigrant parents, with respect to almost all measures of political engagement (Chui, Curtis \& Lambert, 1991). First generation migrants tend to be less fully engaged politically because it takes time and other issues are perceived as being more immediately important (Chui, Curtis \& Lambert, 1991; Viruell-Fuentes, 2006).

The few participants who showed commitment to participate in formal politics in the United States stated that participation is an obligation as a U.S. citizen and that they must vote in order to ensure that Latinos' voices are heard.

Being informed about news from the country of residence is another form of political civic participation. Interviewees demonstrated their desire to be connected and their willingness to know more about the community in which they live. Interest in Oregon news and current affairs among the interviewees was very high. Eighty percent of the sample said they followed the news almost every day. The level of interest was highest among immigrants living in the United States for 20 years or more, at 80 percent, compared to 50 percent among more recent immigrants. 


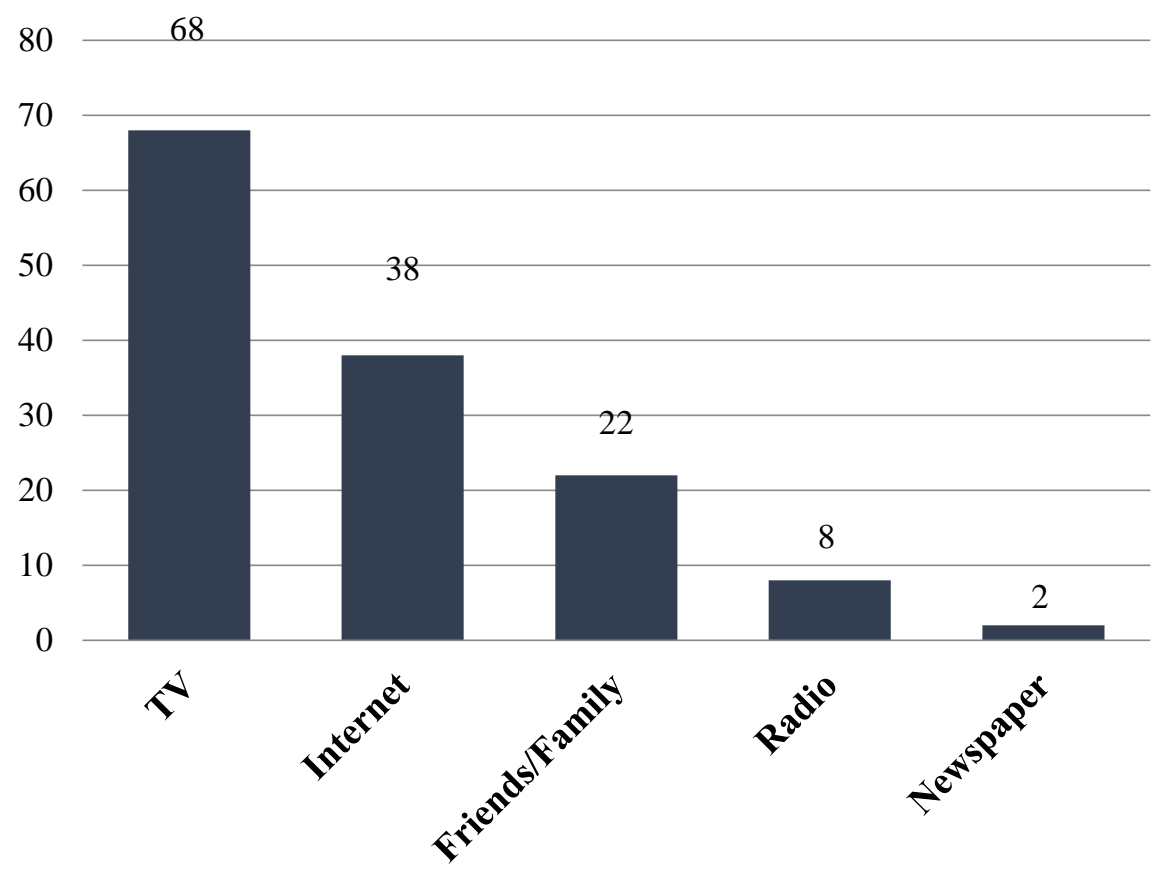

Figure 6.5. How do you make yourself aware of news and current affairs in the U.S.?

People indicated that they are more interested in the news of their community of residence than their community of origin. The news interviewees pay attention to is not only in Spanish, but also from English-language media outlets. Most participants tend to get their news from the TV (68 percent) and the Internet (38 percent), followed by friends and family members (22 percent) as well as the radio (eight percent) and newspapers (2 percent) (See Figure 6.5). Figure 6.6. shows the study participants' most popular news sources. Interviewees get their news equally from social media and from Univision. KGW also provides information for a bulk of the interviewees and FOX 12 Oregon seems to also be a popular news channel for the people interviewed, while only two percent get their news from the Oregonian, the state's largest newspaper, based in Portland. 


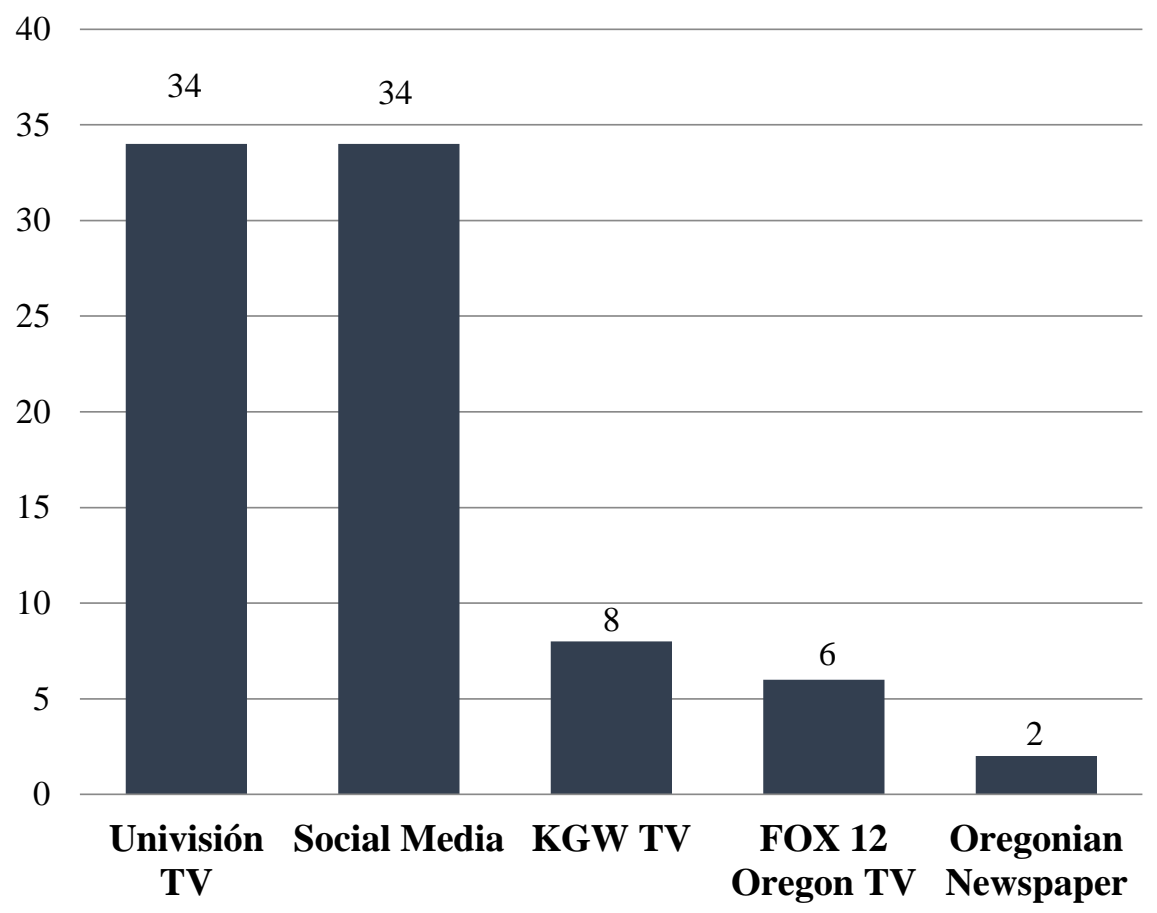

Figure 6.6. What is your most frequently used mode of communication?

Overall, those with legal status $\left(r=0.52, \chi^{2}=14.73\right)$, more years of education $(\mathrm{r}=0.33)$, and higher proficiency in spoken English $\left(\mathrm{r}=0.47, \chi^{2}=25.8\right)$ were more likely to be politically engaged in the U.S. (See Table 6.6.). 
Table 6.6. Political engagement in the United States

\begin{tabular}{|c|c|c|c|c|c|}
\hline $\begin{array}{l}\text { Dependent } \\
\text { Variable }\end{array}$ & Independent Variables & $\begin{array}{l}\text { Chi } \\
\text { Square }\end{array}$ & $\begin{array}{l}\text { Sig }(p \\
\text { Value })\end{array}$ & $\begin{array}{l}\text { Spearman's } \\
\text { Correlation } \\
\text { Coefficient } \\
\end{array}$ & $\begin{array}{l}\text { Sig }(p \\
\text { Value })\end{array}$ \\
\hline \multirow{9}{*}{$\begin{array}{l}\text { Political } \\
\text { Engagement } \\
\text { in US } \\
\text { (POLUS) }\end{array}$} & Age $(<25,25-40,41-60,>60)$ & 12.13 & 0.7 & 0.07 & 0.63 \\
\hline & $\begin{array}{l}\text { Years of Education }(<9,10-15, \\
16-19,>20)\end{array}$ & 16.54 & 0.35 & 0.33 & 0.02 \\
\hline & $\begin{array}{l}\text { Length of time in U.S. }(<10,10- \\
20,21-30,>30)\end{array}$ & 11.41 & 0.72 & 0.03 & 0.81 \\
\hline & Gender $(1=\mathrm{M}, 2=\mathrm{F})$ & 2.24 & 0.81 & 0.06 & 0.7 \\
\hline & $\begin{array}{l}\text { Speaks indigenous language } \\
(0=\text { No, } 1=\text { Yes })\end{array}$ & 3.45 & 0.63 & -0.13 & 0.36 \\
\hline & Legal Status $(0=$ No, $1=$ Yes $)$ & 14.73 & 0.01 & 0.52 & 0.00 \\
\hline & $\begin{array}{l}\text { Income }(<30000,30- \\
50 \mathrm{~K},>50000)\end{array}$ & 9.29 & 0.51 & 0.26 & 0.07 \\
\hline & Urban or rural $(0=$ rural, $1=$ urban $)$ & 4.48 & 0.48 & 0.03 & 0.84 \\
\hline & $\begin{array}{l}\text { Proficiency in Spoken English (1- } \\
\text { poor, 2-gets by, 3-good, 4- } \\
\text { excellent) }\end{array}$ & 25.8 & 0.04 & 0.47 & 0.001 \\
\hline
\end{tabular}

Source: Lopez-Salinas, unpublished data 2016

Regardless of legal status, most of those interviewed are committed to permanent residency in the United States. Eighteen percent of study participants are already naturalized citizens, and 26 percent are permanent residents. Interviewees stated that a U.S. work permit or a U.S. passport would give them the ability to visit their home communities and return to work and live in the United States with more security, which many did not have at the time of the interview. Also, interviewees mentioned that with legal residency, they would have more possibilities to offer a better life to their children through enhanced job prospects. For many, this would mean moving out of poverty.

\section{Social activities in Oregon}

Although Mexican immigrants in Oregon may not join political parties or be able to vote, many are likely to support and volunteer for nonprofit organizations, churches and schools. Therefore, social engagement behavior in this section includes a) 
membership in social organizations in Oregon, b) attendance at sociocultural meetings in Oregon, and c) volunteer work in Oregon.

Sixty percent of the sample is or has been a volunteer in some organization in Oregon. Pro-immigrant organizations, schools, and churches are study participants' favorite places to donate time. None of the background sociodemographic factors makes a significant difference in who volunteers with one exception-legal status. Those who have papers, i.e. those who are in the U.S. legally and have no fear of being arrested or deported, are less likely to be socially engaged $\left(r=-0.36, \chi^{2}=6.58\right)$ and specifically support and volunteer for nonprofit organizations, churches, and schools (See Table 6.7.). Previous studies have suggested that income and educational attainment also influence social participation in the community of residence (Guarnizo, Portes, \& Haller, 2003; Hritzuk \& Park, 2000; Itzigsohn, \& Saucedo, 2002). My sample included some professionals and small businesspeople who indicated that they have the time to devote to volunteer and help the Hispanic and American communities. In the section on paths and barriers to civic engagement, I will specifically address this point.

Also related to legal status is with whom people socially interact. In general, undocumented people relate more closely with people from their own region of origin in Mexico. However, Mexican immigrants who obtain legal status, better paying jobs, and have a better command of English become more cosmopolitan. In this study, interviewees who indicated that they have no problem socializing with people of other nationalities, religions, and genders have legal immigration status, have usually been in the country for longer periods, have a good command of English, and have better paying jobs. Although, 
those with legal status are more likely to be politically and economically engaged and may therefore have less time for social engagements.

While men and women may be similar in their overall rates of volunteering, gender still makes a difference. Women's involvement in their children's schools contrasts with men's greater interest in participating in social engagement with their communities of origin, related to men's civic roles in home communities and greater earnings (Preston, Kobayashi \& Man, 2006). Men also outnumber women as economic supporters of social causes in their communities of origin. Therefore, contrary to studies that state that the presence of children does not increase social engagement among immigrant women (Couton \& Gaudet, 2008), this research suggests that women tend to be more involved in their communities of residence and men tend to be more involved in their communities of origin. These results support findings from studies of indigenous Mexican immigrants in the United States (Canedo Vasquez, 2008; Carlsen, 1999). 
Table 6.7. Social engagement in Oregon

\begin{tabular}{|c|c|c|c|c|c|}
\hline $\begin{array}{l}\text { Dependent } \\
\text { Variable }\end{array}$ & Independent Variables & $\begin{array}{c}\text { Chi } \\
\text { Square }\end{array}$ & $\begin{array}{l}\text { Sig }(p \\
\text { Value })\end{array}$ & $\begin{array}{l}\text { Spearman's } \\
\text { Correlation } \\
\text { Coefficient }\end{array}$ & $\begin{array}{l}\text { Sig }(p \\
\text { Value })\end{array}$ \\
\hline \multirow{9}{*}{$\begin{array}{l}\text { Social } \\
\text { Engagement } \\
\text { in USA } \\
\text { (SOCIOUS) }\end{array}$} & Age $(<25,25-40,41-60,>60)$ & 0.94 & 0.82 & -0.11 & 0.45 \\
\hline & $\begin{array}{l}\text { Years of education }(<9,10- \\
15,16-19,>20)\end{array}$ & 2.41 & 0.93 & -0.14 & 0.35 \\
\hline & $\begin{array}{l}\text { Length of time in U.S. }(<10, \\
10-20,21-30,>30)\end{array}$ & 5.44 & 0.14 & 0.02 & 0.91 \\
\hline & Gender $(1=\mathrm{M}, 2=\mathrm{F})$ & 0.32 & 0.57 & -0.08 & 0.58 \\
\hline & $\begin{array}{l}\text { Speaks indigenous language } \\
(0=\mathrm{No}, 1=\text { Yes })\end{array}$ & 0.34 & 0.56 & -0.08 & 0.57 \\
\hline & Legal status $(0=$ No, $1=$ Yes $)$ & 6.58 & 0.01 & -0.36 & 0.01 \\
\hline & $\begin{array}{l}\text { Income }(<30000,30- \\
50 \mathrm{~K},>50000)\end{array}$ & 0.66 & 0.72 & 0.09 & 0.55 \\
\hline & $\begin{array}{l}\text { Urban or rural }(0=\text { rural, } \\
1=\text { urban })\end{array}$ & 0.09 & 0.77 & 0.04 & 0.77 \\
\hline & $\begin{array}{l}\text { Proficiency in spoken } \\
\text { English (1-poor, 2-gets by, 3- } \\
\text { good, 4-excellent) }\end{array}$ & 4.98 & 0.17 & -0.23 & 0.12 \\
\hline
\end{tabular}

Source: Lopez-Salinas, unpublished data 2016

\section{Summary}

In general, respondents with higher engagement in Mexico were people who spoke an indigenous language, and have not acquire legal status in the United States. Although, political engagement in Mexico was not influenced by any independent variable it may be to the fact that Mexicans interviewed do not trust the Mexican government and hence are not interested in formal political engagement.

Respondents with higher engagement in the United States were people with higher proficiency in spoken English, higher income, acquired legal status and did not speak an indigenous language. However, participants who have acquired legal status seems to be more engaged in economic and political activities in the United States than in social engagements. 


\section{Changes in Mexican Immigrants' Civic Engagement with Communities of Origin and Communities of Residence in Oregon}

The closed ended questions detailed in the following section aimed to provide an understanding of changes in civic engagement in the Mexican immigrant community. In addition to the closed ended questions, this section is enriched by the participants' perceptions of the changes of civic engagement over time. This quantitative and qualitative phase allows me to answer the following research question:

RQ 2: Does the engagement of immigrants with their home communities detract from engagement in Oregon, or enhance it? Has this relationship changed over time?

This section provides an overview of changes in Mexican immigrants' engagement (bridging service, political, and social) while they were in Mexico and since they moved to the United States. The structured analysis of this research is adapted from Labissiere, Reeder Goraczko and Stepick's (2009) study on Religious Practice and Civic Social Capital among Miami Young where the authors analyzed the relationship between religious practices and civic social capital.

\section{Bridging service activities}

Table 6.8. indicates that nearly 60 percent of interviewees volunteered or performed community service in the United States, compared to 20 percent that performed community service in Mexico. The age of the participants may help to explain this change in engagement since 28 percent of the interviewees left Mexico when they were younger than 18 years old. 
Table 6.8. Bridging service, political, and social activities in Mexico and in the United States

\begin{tabular}{|c|c|c|}
\hline & $\begin{array}{c}\text { Percent who } \\
\text { participated } \\
\text { frequently or } \\
\text { very } \\
\text { frequently } \\
\text { MEXICO }\end{array}$ & $\begin{array}{l}\text { Percent who } \\
\text { participated } \\
\text { frequently or } \\
\text { very frequently } \\
\text { U.S. }\end{array}$ \\
\hline \multicolumn{3}{|l|}{ Bridging Service } \\
\hline Volunteer or Community Service & $20 \%$ & $58 \%$ \\
\hline Participated in Community Fundraiser & $36 \%$ & $50 \%$ \\
\hline Donated blood & $0 \%$ & $2 \%$ \\
\hline Tutor some one & $6 \%$ & $20 \%$ \\
\hline Help a recent immigrant & $20 \%$ & $52 \%$ \\
\hline Help senior citizens & $22 \%$ & $26 \%$ \\
\hline Join an organization & $18 \%$ & $42 \%$ \\
\hline \multicolumn{3}{|l|}{ Political } \\
\hline Discuss politics with friends or family & $40 \%$ & $46 \%$ \\
\hline $\begin{array}{l}\text { Use internet to keep up with current } \\
\text { events }\end{array}$ & $44 \%$ & $78 \%$ \\
\hline $\begin{array}{l}\text { Read newspaper to keep up with } \\
\text { current events }\end{array}$ & $18 \%$ & $28 \%$ \\
\hline Participate in organized demonstrations & $20 \%$ & $32 \%$ \\
\hline Officer of an organization & $10 \%$ & $28 \%$ \\
\hline Attend a public meeting & $20 \%$ & $22 \%$ \\
\hline \multicolumn{3}{|l|}{ Social } \\
\hline Have friends over to your home & $82 \%$ & $38 \%$ \\
\hline Visit neighbors over to their home & $68 \%$ & $26 \%$ \\
\hline $\begin{array}{l}\text { Visit relatives in person or had them } \\
\text { visit you } \\
\text { Group Member }\end{array}$ & $88 \%$ & $54 \%$ \\
\hline $\begin{array}{l}\text { Attend church or other religious } \\
\text { activity } \\
\text { Activity }\end{array}$ & $44 \%$ & $52 \%$ \\
\hline Attend family reunions & $88 \%$ & $38 \%$ \\
\hline Athletic activities & $34 \%$ & $56 \%$ \\
\hline
\end{tabular}

Source: Adapted from Labissiere, Reeder Goraczko \& Stepick (2009)

Some interviewees spoke positively about their volunteer service in the U.S. and others expressed mixed reactions. Don Gonzalo, who has been in Oregon for more than twenty years explained that Mexicans grow up with the belief that the U.S. has taken 
advantage of Mexico and once Mexicans are in the U.S., regardless of their legal status, they do not care about engaging with their community of residence. However, participants' willingness to collaborate and participate in their communities of residence increases as they spend time in the U.S. This increased participation is further developed if they have children born in the U.S. and feel that the country has given them the opportunity to provide for their families.

Ese resentimiento lo traemos de chicos porque a nosotros se nos dice que Estados Unidos es malo, que Estados Unidos le quito las tierras a México, que Estados Unidos es capitalista, que nos pisotean, que nosotros somos el jardín que tienen atrás de su casa y que toda la basura viene para acá, no es totalmente cierto eso, el gobierno es el que tiene el poder de hacer todas esas cosas, y el gobierno mexicano lo ha permitido.

Cuando mis hijos empezaron a crecer y empezaron a ver el futbol, obviamente le van a ir a su país (Estados Unidos), no le puedo ir a Corea cuando todos mis hijos están a favor de Estados Unidos, ¿qué me ha dado Corea a mí? Estados Unidos me ha dado mucho. Es otra forma de ver las cosas, gracias a Estados Unidos hay 12 millones de emigrantes que estamos mandando dinero a México, ¿entonces por qué esa ideología? hay ciertos aspectos en el que si nos han fregado, pero es el sistema, en muchas cuestiones nos ha favorecido que Estados Unidos esté cerca de México porque de alguna forma no estamos más jodidos como Salvador, Guatemala u otros países africanos, siempre hay dos caras de la moneda. 
We bring resentment from when we are children because we are told that America is bad, that the United States stole the land from Mexico, the United States is a capitalist country which tramples on us, that we are its back yard and all their trash is thrown in Mexico. This is not entirely true, the government is the one that has the power to do all those things, and the Mexican government has allowed it. When my children here started to watch soccer, obviously they rooted for their country (United States). I cannot root for Korea when all my children are in favor of the United States. What has Korea given me? America has given me a lot. It is another way of looking at things. Thanks to the United States there are 12 million migrants that are sending money to Mexico, then why this ideology? There are certain aspects in which if we have been bothered, it is because of the system, on many issues it has favored us that the U.S. is close to Mexico because somehow we are not as messed up as El Salvador, Guatemala, and other African countries, there are always two sides of the coin.

On the other hand, referring to the same volunteering and/or community service activities done in Mexico, people from indigenous descent expressed their commitment to their communities of origin and how this commitment was established and reinforced through their family members, while growing up in those communities.

Tú vienes de una ciudad muy grande donde hay todo, tú quizás sufrías porque a lo mejor no tenías mucho dinero para tener todo lo que tu quisieras, pero yo vengo de un pueblo muy chiquito, de un pueblo de Oaxaca donde no hay nada, nosotros nos venimos aquí desde niños y desde entonces mis padres me ensenaron a ayudar 
a mi pueblo, yo me siento muy orgullosa de mi familia porque cada vez que se les requiere mandan dinero a su pueblo, hacen una fiesta cada año y esa fiesta se hace con dinero de todos, si se hace algo en el pueblo se manda dinero... para mi, mis respetos para toda esa gente, para mí son personas que valen mucho, mis hijos simplemente dice que este tipo de personas valen demasiado porque son personas de buen corazón que tienen la voluntad de ayudar a su pueblo.

You come from a big city where there is everything, maybe you were suffering because you did not have much money to have everything you wanted. But I come from a very small town, a town in Oaxaca where there was nothing, we came here as children and since then my parents taught me to help my people. I am very proud of my family because every time there is something required they send money to the town, they organize a party every year and this event is done with the money of all. If they do something in the village, money is sent ... my respects to all those people, for me they are people who are worth much, my children simply say that this kind of people are worth much because they are people with good hearts willing to help their town.

As reflected in Table 6.8., the majority of the sample engaged in some form of service activity such as helping a recent immigrant, helping senior citizens, and joining organizations. Perhaps more surprising, nearly 40 percent have joined an organization while in the U.S. compared to 18 percent who did the same while they were in Mexico. 
No interviewees donated blood while living in Mexico, while only one person has done so while in the United States.

Table 6.9. presents a summary index for Bridging Service Activities which is created by summing each individual's participation in bridging service activities and then calculating the mean for each subgroup of gender, age, marital status, and length of time in the United States. As shown in Table 6.9. people who are male, between the age of 2650, married, or who have lived in the United States for less than ten years have done the most bridging service activities.

\section{Table 6.9. Bridging Service activities in Mexico and in the United States summary index}

\begin{tabular}{|lrr|}
\hline \multicolumn{1}{|c}{ Variable } & \multicolumn{1}{c|}{$\begin{array}{c}\text { MEX } \\
\text { \% }\end{array}$} & \multicolumn{1}{c|}{ USA } \\
\hline Gender & & \\
Male & 56.52 & 51.43 \\
Female & 43.48 & 48.57 \\
Age & & \\
$0-25$ & 8.7 & 2.86 \\
$26-50$ & 56.52 & 77.14 \\
$51+$ & 34.78 & 20 \\
Marital Status & & \\
Married & 52.17 & 60 \\
Divorced & 8.7 & 8.57 \\
Single & 26.09 & 20 \\
Union libre & 13.04 & 11.43 \\
Years in the U.S. & & \\
<=10 & 56.52 & 54.29 \\
11=>20 & 13.04 & 20 \\
=>21 & 30.43 & 25.71 \\
\hline
\end{tabular}

Source: Adapted from Labissiere, Reeder Goraczko, \& Stepick (2009). 
Additionally, Table 6.9. shows that men have a slight majority for the highest average in bridging service activities in the Unites States. Similar results are found for the variable of marital status, length of time in the U.S., and the age of the people interviewed.

\section{Political activities}

Nearly 20 percent of the sample indicated that they had participated in a political demonstration of some kind when they were in Mexico. Since they arrived in the United States, this percentage has increased. Thirty two percent of the sample has participated frequently or very frequently in organized political demonstrations. Many of the political demonstrations in the U.S. are related to Mexico's social and political problems. Participation in political demonstrations related to Mexico was particularly high at the time of the interview due to current political events. On September 26, 2014, the disappearance of 43 indigenous Mexican students caused a dramatic political and social struggle, not just in Mexico but almost everywhere around the globe where Mexicans reside. 


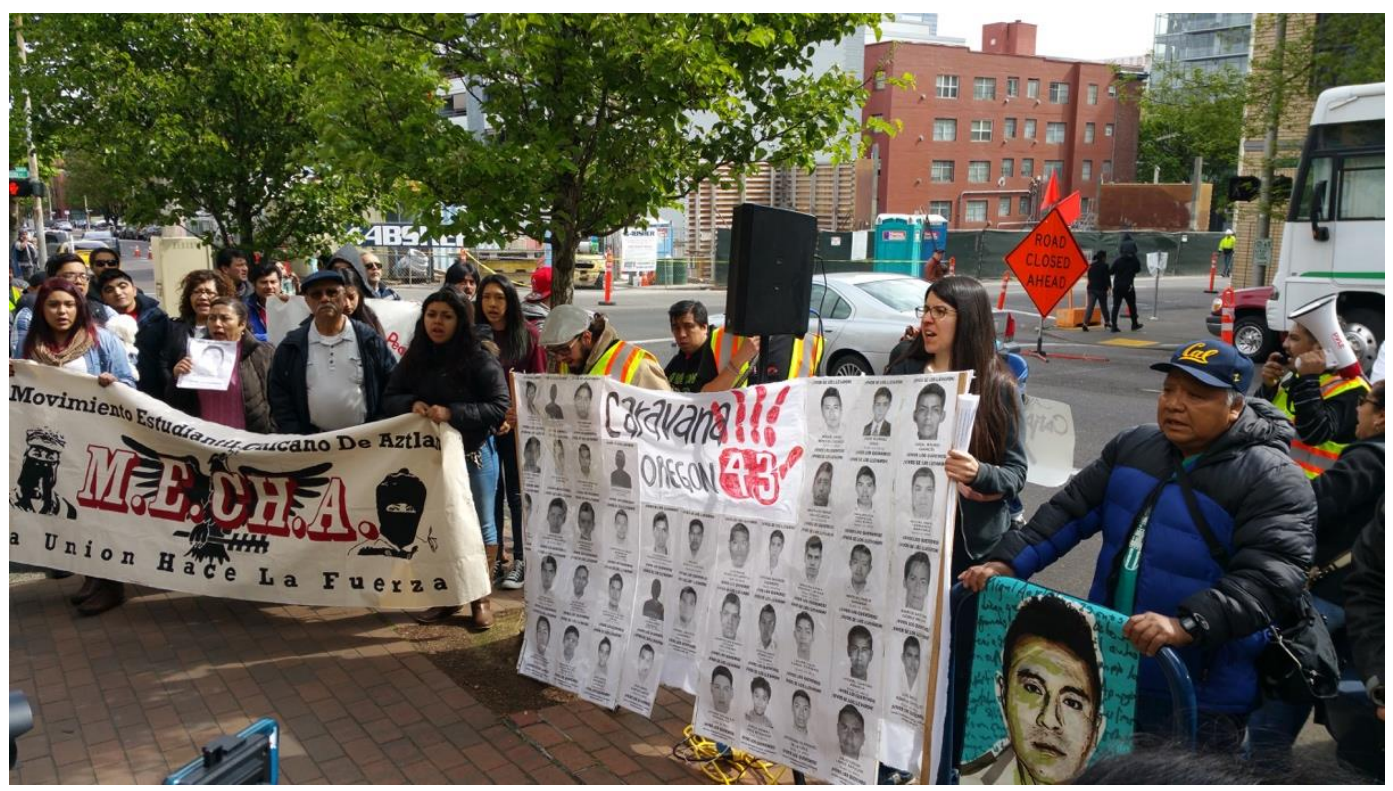

Figure 6.7. Demonstration outside the Mexican Consulate in Portland for the visit of some of the parents of the Ayotzinapa missing students.

The metropolitan areas of Portland and Salem witnessed protests for the missing students organized by the Mexican population residing in these areas. On several occasions after the events of September 2014, many people of Mexican origin have shown their dissatisfaction with the Mexican authorities by protesting outside of the Consulate of Mexico in the city of Portland, accompanied by people from other Latin American countries, U.S. citizens, and the media.

Lloramos cada día por no ver crecer a nuestros hijos, si todo estuviera bien en México, si en México hubiera trabajo, si en México no hubiera todas esas injusticias, allá estaríamos, no estaríamos aquí, no estaríamos dando molestias, siendo discriminados por los americanos, siendo humillados por ellos, allá estaríamos en México, ¿que estaríamos haciendo aquí? yo quiero estar en mi México, ¿pero cómo? si hay pobreza, hay desgracias, hay impunidad, hay 
asesinatos. Le tenemos miedo al gobierno; pero si nos unimos todos no vamos a tener más miedo, vamos a regresar a nuestro país a ver todo lo bonito que tenemos en México... rico nuestro país, ¿pero qué hace el gobierno americano? Está robando a México nuestro petróleo, todas nuestras riquezas. Aquí estamos para trabajar porque no venimos a robar, estamos trabajando para darle estudios a nuestros hijos.

We cry every day for not seeing our children grow. If all were well in Mexico, if there had been work, if there had not been all these injustices, we would be there, we would not be here, we would not be being bothered, being discriminated against by the Americans, being humiliated by them, we would be in Mexico, what would we be doing here? I want to stay in my Mexico, but how can I? If there is poverty, misery, impunity, killings, and so on? We fear the government; but if we unite we will not have more fear, we will return to our country to see all the beauty we have in Mexico ... our rich country, but what does the American government do? It is stealing our oil from Mexico, all our wealth. We are here to work because we did not come to steal, we are working to give our children education. 


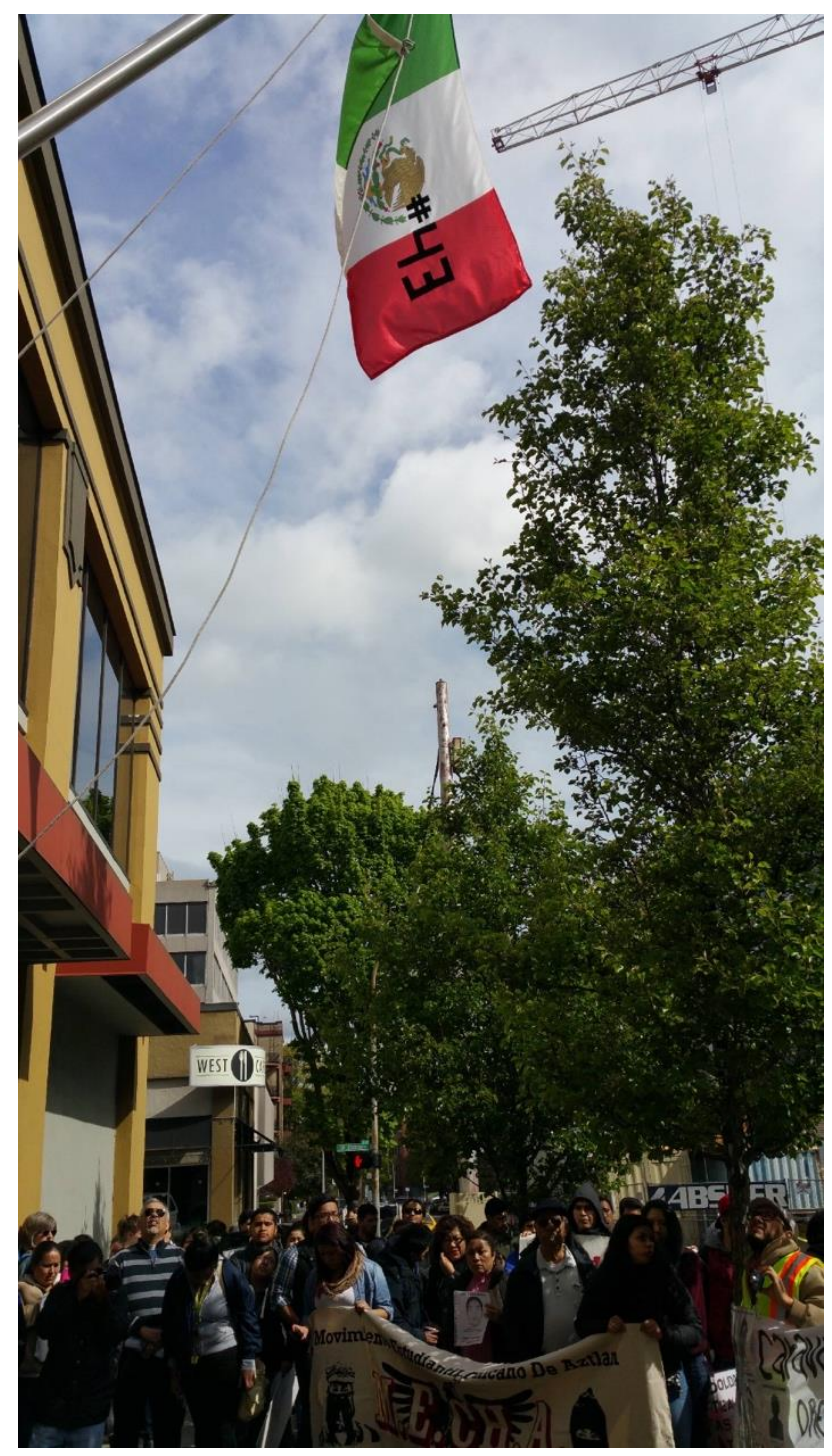

Figure 6.8. A Mexican flag with the sign of the 43 missing students was raised outside of the Mexican Consulate in Portland

Similar patterns emerge for participants' political discussions with friends and family. Forty percent used to have political discussions while in Mexico and 46 percent have done so in the U.S. Many interviewees, 28 percent, read newspapers to keep up with current events as compared with 18 percent who did so in Mexico. About $1 / 5^{\text {th }}$ of the 
sample attended a public meeting in Mexico compared to 22 percent who have attended a public meeting in the United States.

Here, study participants are much more likely to use the internet to keep up with current events, 78 percent reported doing so in the U.S., as compared to 44 percent in Mexico. For this sample, participants' average length of time residing in the US is sixteen years, with 66 percent of the sample coming from an urban background. Just ten years ago the use of the Internet in Mexico was very limited, even in urban areas. Interviewees stated that recently the majority have started using the internet more frequently, not only to keep themselves updated with current political events, but also to communicate with their families in Mexico through social media.

It appears that study participants have increased their participation as officers of organizations here in the United States, 28 percent, compared to those who served in an organization in Mexico, 10 percent. People see the United States as a fair political system and this increases their likelihood to become politically active. Luis, a naturalized US citizen originally from Guadalajara, Jalisco, who teaches Latino entrepreneurship practices and strategies to open small business, states the importance of voting and the creation of boards as an enforcement mechanism of democracy, for and by the people, in the United States.

El hispano no vota no porque no le interesa, en primer lugar, el voto no es sinónimo de democracia, en nuestros países el voto se lo roban, lo queman o lo compran y venden, entonces la gente está decepcionada porque piensa que el voto no vale o cuando ya vote por la gente, esta me engaña; pero yo le digo a la gente que el voto es solamente una herramienta, la otra herramienta es la supervisión, 
hay que votar pero hay que quedarse a supervisar a ver que hacen con tus votos, una herramienta son los boards. Por eso es que aquí está más controlada la corrupción que en México, aquí se hacen comités ciudadanos, aquí van a saber a quién les van a dar los contratos, a nosotros como hispanos nos usan como estadística, pero por lo menos te toman en cuenta y en mis clases eso recalco, que ustedes tienen que ser líderes de su comunidad, tenemos las mismas habilidades que cualquier otra raza, que cualquier otra gente y solamente a veces tenemos menos oportunidad académica por lo problemas económicos, pero debemos tratar de empoderar verdaderamente a la gente.

Hispanics do not vote in Mexico but not because they are not interested. First, voting is not synonymous with democracy in our countries, the vote is stolen, they burn it or buy and sell it, then people are disappointed because they think voting is not worth it or when I voted for somebody, he/she tricks me. Here in the U.S. I tell people that voting is only one tool, the other tool is monitoring. We have to vote and we have to stay to supervise to see what they do with our votes, a tool used by the boards. That's why here corruption is more controlled than in Mexico, here there are citizens committees, here you will know who they are going to give contracts. We as Hispanics are used as statistics, but still we are taken into account and in my classes I emphasize that, you have to be leaders of your community, you have the same skills as any other race, only sometimes we have less academic opportunity due to economic problems, but we try to truly empower people. 
Like many other Latinos, Pablo, a naturalized U.S. citizen, who obtained a Bachelor of Arts in marketing in Mexico, felt as if he could do more to engage the Latino community with his marketing skills, and that belief prompted his political engagement. Pablo believes that the engagement among the Latino community in Oregon can be increased by using "marketing techniques with a social emphasis, by exaggerating the characteristics of the product." Today, Pablo is one of the few well recognized Mexicans in Oregon. He was been nominated to receive several awards at the state and national level for his engagement and support of the Latino community. Voicing a similar sentiment to many of the other interviewees, Pablo stated that "Mexicans are desterrados economicos" (economic exiles) because the Mexican government is unable to provide for its citizens and they have been forced to leave their families and settle in the United States. Pablo uses several means of communication to share his ideas against the "atrocities committed by the Mexican government." Pablo believes that public officials work for the people and should be held accountable whether in the United States or in Mexico.

As Table 6.10. indicates there are no differences by gender, marital status or length of time in the United States when it comes to performing political activities both in Mexico and in the United States. Although, it appears that participants between the ages of 26 to 50 years old perform more activities in the US (80.95 percent, compared to 73.53 percent while in Mexico).

Table 6.10. Political activities in Mexico and in the United States summary index 


\begin{tabular}{|lrr|}
\hline \multicolumn{1}{|c}{ Variable } & \multicolumn{1}{c|}{$\begin{array}{c}\text { MEX } \\
\text { \% }\end{array}$} & \multicolumn{1}{c|}{ \% } \\
\hline Gender & & \\
Male & 55.88 & 54.76 \\
Female & 44.12 & 45.24 \\
Age & & \\
$0-25$ & 5.88 & 2.38 \\
$26-50$ & 73.53 & 80.95 \\
$51+$ & 20.59 & 16.67 \\
Marital Status & & \\
Married & 58.85 & 59.52 \\
Divorced & 8.52 & 4.76 \\
Single & 26.47 & 26.19 \\
Union libre & 5.88 & 9.52 \\
Years in the US & & \\
<=10 & 50 & 50 \\
11=>20 & 29.41 & 26.19 \\
=>21 & 20.59 & 23.81 \\
\hline
\end{tabular}

Source: Adapted from Labissiere, Reeder Goraczko, \& Stepick (2009).

In general, study participants feel that the U.S. the government is far less corrupt than the Mexican government; however, they stated that the U.S. government also shows signs of corruption and that as time passes, people may realize that corruption levels are lower but still exist. Andres, from a rural community in Puebla, reflects a relatively pessimistic political point of view.

Es lo mismo, nada más que aquí lo tapan mas, uno ya lleva más tiempo aquí y se da cuenta de las cosas, el gobierno solo quiere dinero, si tienes dinero te arregla papeles, lo mismo con lo de sacar los permisos, es puro dinero y también con la situación de la amnistía a nivel nacional, les conviene que paguemos más que construir el muro. 
It's the same, here they cover it more, one has more time here to realize things, the government only wants money, if you have money you can arrange your papers (legal documentation). As with getting permits, it is all about money and also with the situation of the amnesty at the national level, for them it is better if we pay more for that than to build the wall.

The internet and the length of time spent in the United States appear to help increase participants' political engagement with their communities of residence and with their communities of origin. However, the sample indicates that overall there is not significant engagement in political activities in their communities of residence.

\section{Social Activities}

Putman's concept of social capital helps us understand its critical importance within the immigrant community. Social relations often serve as instruments to help immigrants settle in their new communities of residence and these social relationships may help them find a job and better opportunities (Labissiere, Reeder Goraczko, \& Stepick, 2009). Social activities create path for immigrant political engagement and bridging service activities (Labissiere, Reeder Goraczko, \& Stepick, 2009).

Since Mexicans immigrants came to Oregon, they have been socially engaged in every kind of social activity. As reflected on Table 6.8, the majority of the interviewees engaged in peer group activities, such as having friends over, visiting relatives in person, and attending family reunions. However, it is clear that the pursuit of social activities decreased once immigrants moved to the United States. Although, attending church or other religious activities and athletic activities increased after study participants moved to 
the U.S. Juan, an immigrant from Oaxaca and has been in Oregon for more than sixteen years, states that he has approximately ten family members living in the Portland metropolitan area, but they are not as united as they were in Mexico. Georgina, from a rural community in the state of Puebla who has been in the U.S. for over fifteen years and whose community of origin has approximately 200 members living in the Portland metropolitan area, explains why people do not visit each other as often as they did when they were in Mexico.

Aquí venimos a trabajar, no hay mucho tiempo libre, en las tardes solo quieres descansar y aunque quieras visitar a tus amigos o familia, la verdad es que no sabes sus horarios y piensas que quizá estén también cansados. Hay muchas fiestas porque la mayoría de los paisanos tiene hijos, en esas fiestas nos encontramos casi todos los del pueblo, pero no nos buscamos a parte de las fiestas.

Here we come to work, we do not have much free time. After work in the evenings you just want to relax and if you want to visit friends or family, you really do not know their schedules and you think that perhaps they are also tired. There are many parties because most people from my town (paisanos) have children, in these fiestas we find almost all the people from our town, but we are not visiting each other besides the festivities.

Over all, this sample contains people with higher levels of educational attainment, compared to the majority of the Mexicans residing in Oregon. This higher level of 
educational attainment has given them the opportunity for better jobs. Immigrants with more stable jobs have the time to exercise. Interviewees also mentioned that they do not want to get sick or gain weight since they came to the United States, so they feel obligated to exercise frequently. Raul, an immigrant from Mexico City who works as a cook and has been in Oregon for over fifteen years states the importance of exercising as a measure of preventing chronic diseases.

Cuando yo estaba en la ciudad, caminar no era un ejercicio era parte de la vida diaria. Aquí en Oregon necesitas carro para todo y la gente casi no camina, por eso estamos enfermos, por eso estamos diabéticos y gordos. En la casa tratamos de caminar en las tardes y tenemos una bici estacionaria que ocupamos cuando está lloviendo y no podemos salir. A este país vienes a dejar tu juventud y tu salud si no las cuidas, por eso es importante el ejercicio.

When I was in the city [Mexico City], walking was not an exercise, it was part of daily life. Here in Oregon you need a car for everything and people hardly walk, so we are sick, diabetic and overweight. At home we try to walk in the evenings and have a stationary bike to use when it's raining and we cannot get out. In this country you can lose youth and your health if you do not take care, so it is important to exercise.

Margarita a young immigrant from Mexico City who has been in the United States for more than sixteen years, states that playing soccer, which she has done since she was a child, has given her the ability to know and interact with many people that she would otherwise never have met. 
Yo empecé a jugar desde los siete años, jugaba con mi hermano y mi papá, desde que llegué a Estados Unidos empecé a jugar en la High School y desde entonces he estado en varios torneos, es una forma de socializar, depende de tu actitud pero he llegado a conocer a mucha gente de otros países en América Latina; esa gente también siente que es una pasión por el deporte, no importa si no vas a conocer gente, ahí de todas maneras harás amigos, la cosa es ir a tocar el balón, a des estresarte, a aprender más del futbol.

I started playing at age seven, playing with my brother and my father. Since I came to America I started playing in high school and since then I have been to several tournaments, it's a way to socialize, it depends on your attitude but I have gotten to know many people from other countries in Latin America; these people also feel it is a passion for the sport, it does not matter if you do not go there to meet people, you will end up making friends anyways, the thing is going to touch the ball, to de-stress, to learn more about soccer. 


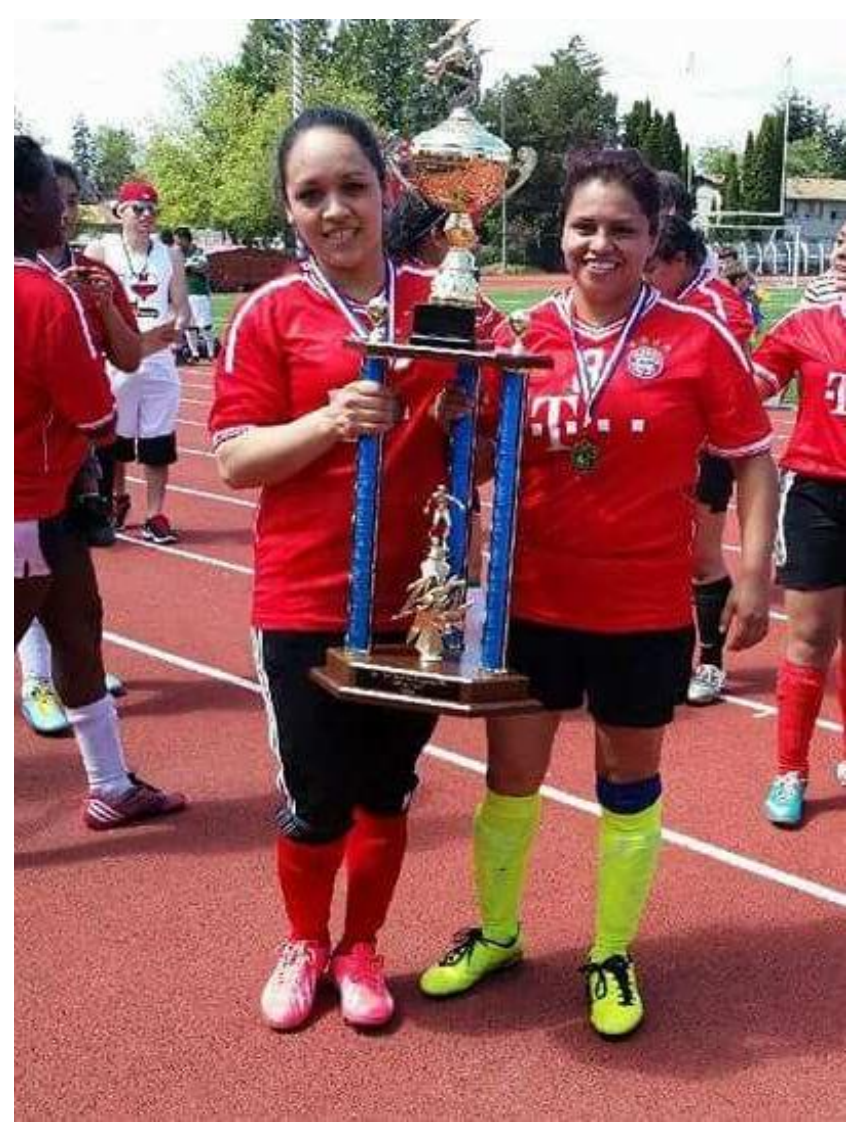

Figure 6.9. Margarita (right) after her soccer team won a tournament, on the grounds of Pacific University in Forest Grove, Oregon

Indeed, a majority of immigrants engaged in activities with family and friends while they were in Mexico. Attending church and exercising increased once they come to the U.S. Increased engagement in religious activities is commonly mentioned in the literature as often the most visible form of Latino civic engagement in the United States (Stepick, Rey, \& Mahler, 2009).

The findings in this study coincide with the work of Sanchez Diaz de Rivera and Hernandez Rojas (2012) which found that for "the migrant, national sentiment is not confused with citizenship, it is more cultural than political." Religion is often a common factor for civic participation of transnational migrants and is considered as "an important 
organizing principle of social relations and, in some ways, also an anchor point for families who have immigrated to America" (Rivera Sánchez, 2011, p. 67). The findings of this study also coincide with the results of the research I conducted in 2012 on religious practices of migrants from Molcaxac, Puebla, living in the metropolitan area of Portland. For most Molcaxaquences, the celebration of La Virgen de la Asuncion (Lady of the Assumption), on August 15 of each year, is usually an activity of great importance. Molcaxaquences living in the United States keep this tradition alive. Molcaxaquences who live in the Portland metropolitan area fundraise for this festivity and it is seen as a priority among those living in Oregon, regardless of their socio-economic status. For the celebration of the festivity of La Virgen de la Asunción in 2012, the Molcaxaquences living in Oregon raised a little more than eighty thousand pesos $(\$$ 7,000) through prayers, individual and collective cooperation, carnivals, and raffles. This money was used for the floral decoration of the church in Puebla. The celebration of the Virgin of the Assumption is also carried out in other parts of Oregon. Molcaxaquences live "as if they were in their village" and give thanks to the Virgin for everything they have achieved in this country and ask for the welfare of their families in Mexico and in the United States. 


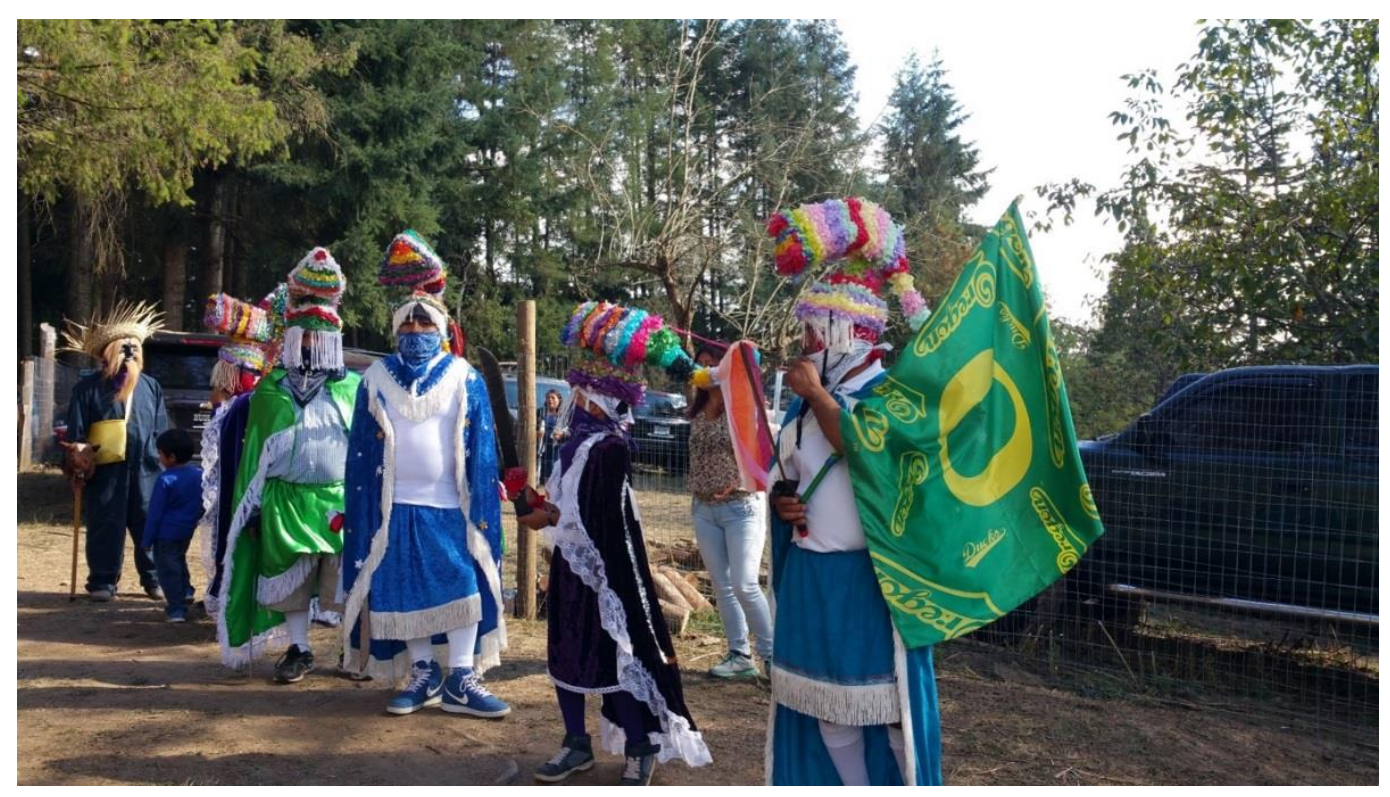

\section{Figure 6.10. 2015 San Mateo Tonuchi (Oaxaca) community celebration in Mulino, Oregon}

The Molcaxaquences in Oregon, as other Mexicans from rural communities, are mainly Catholic. Besides organizing celebrations and making every effort to raise money for their religious holidays, Molcaxaquences regularly attend masses in Spanish in various local churches. Martin, from Molcaxac, is part of the Ministry of Hospitality ${ }^{4}$ at St. Matthew Catholic Church in Hillsboro, and arrives every Sunday to church at 6:45 am, with the "purpose of serving the Lord and finding peace, because for us it is like a therapy that makes us feel quite happy" (Female, Puebla, cleanliness worker, undocumented).

\footnotetext{
${ }^{4}$ The Ministry of Hospitality consists of twelve people of Hispanic origin, four from Molcaxac, this team is dedicated to welcome the parishioners who come to church to collect the offering and lay Catholics faithful after Mass.
} 
Table 6.11. Social activities in Mexico and in the United States summary index

\begin{tabular}{|lrr|}
\hline \multicolumn{1}{|c}{ Variable } & MEX\% & \multicolumn{1}{c|}{ USA \% } \\
\hline Gender & & \\
Male & 52 & 51.11 \\
Female & 48 & 48.89 \\
Age & & \\
$0-25$ & 6 & 4 \\
$26-50$ & 78 & 77.78 \\
$51+$ & 16 & 17.78 \\
Marital Status & & \\
Married & 56 & 57.78 \\
Divorced & 6 & 6.67 \\
Single & 24 & 20 \\
Union libre & 14 & 15.56 \\
Years in the US & & \\
<=10 & 52 & 55.56 \\
$11=>20$ & 26 & 20 \\
=>21 & 22 & 24.44 \\
\hline
\end{tabular}

Source: Adapted from Labissiere, Reeder Goraczko \& Stepick's (2009).

Table 6.11. presents a summary index for social activities with overall averages as well as averages for gender, age, marital status, and length of time in the United States. There is no significant difference in gender, age, and marital status for changes in the level of social engagement in Mexico and in the United States. Men in the sample tended to be slightly more socially engaged in Mexico, and women a little bit more engaged in the U.S. Table 6.11 also shows that Mexican immigrants' engagement in the United States increases with time.

\section{Summary}

Overall, similar to studies in other states (Odgers \& Touraine, 2001; Sanchez Diaz de Rivera \& Hernandez Rojas, 2012), Mexicans residing in Oregon are involved in more volunteer activities than political ones. Also consistent with other studies (Hondagneu- 
Sotelo, 1994; Itzigsohn \& Giorguli-Saucedo, 2005), women are more engaged in their communities of residence than men (Hondagneu-Sotelo, 1994; Itzigsohn \& GiorguliSaucedo, 2005).

This research shows that the Mexican immigrants interviewed in this study are willing to volunteer in the United States. These immigrants tend to volunteer more in the US than they did in Mexico by offering their time through community service, helping senior citizens, tutoring people, participating in community fundraisers, and helping newly arrived immigrants, perhaps because they are older and can relate to migrant community.

The interviewees have also participated in political events and have become more interested in politics since moving to the U.S. Their chances of becoming officers or holding key positions in organizations and becoming more informed about politics in the US and in Mexico has also increased upon moving to the U.S.

The results of this study showcase the importance for interviewees in keeping ties to their family, friends, and community. However, since moving to the United States, interviewees tend to spend less time with family members outside of their nuclear family even if they live in the same US community. This trend is probably due to the fact that work becomes the number one priority to support their nuclear families. At the same time, most participants have increased their memberships with social organizations since moving to the U.S. Churches and league sports were commonly mentioned as ways to engage in the study participants' communities of residence.

The interviewees have been adjusting to the lifestyle of their communities of residence and in many cases, appreciate the lifestyle and the security their communities 
of residence offer them. This appreciation and feeling of security makes planning for a date to return to Mexico ambiguous. However, Mexicans residing in Oregon reproduce the customs of their communities of origin, mainly through religious activities and organizations, which characterizes transnational engagement. In general, Mexicans living in Oregon recreate the customs of their communities of origin while simultaneously learning new ways of interacting with their communities of residence in order to lead a "peaceful and normal life" in the U.S. This trend is consistent with other studies (Escamilla Hamm, 2009; Portes, 1999) that show for the Mexican transnational community, civic participation is a complementary process between both their communities of origin and their communities of residence, rather than isolated cases. 


\section{Paths and Barriers to Mexican Immigrant Civic Engagement in Oregon}

The open ended questions detailed in the following section aimed to provide a deeper understanding of the contexts and processes of civic engagement in the Mexican immigrant community. The people interviewed for this study provided important information about the situational contexts shaping patterns of civic engagement in the Salem and Portland metropolitan areas. This qualitative phase allowed me to answer the following research questions:

RQ 3. What are the issues with which participants are most often engaged in their communities of residence?

RQ 4. What are the barriers that most deter participants from civic engagement in their communities of residence?

RQ 5. Which organizations do this group of immigrants work with on civic issues? How?

The focus of this section of the study was the range of paths to civic engagement experienced by the study participants. The derived categorizing of perceived experiences resulting from the interviews is presented next.

\section{Paths to Mexican immigrants' civic engagement}

Engagement through community pride. Tucker and Santiago (2013) states the importance of immigrants becoming part of their neighborhood by owning houses and feeling proud of their neighborhoods. Then, owning houses and paying taxes are important variables for this category because 80 percent of the people interviewed pay taxes regardless of their legal status, which speaks to their commitment and responsibility 
to the community where they reside. For this sample, 36 percent of the participants owned their homes in the Salem and Portland metropolitan areas. Interviewees listed the most important reasons for owning a home in Oregon as security for their family, and especially for their children, and their willingness to stay in Oregon because of the security it provides and the natural beauty of the state.

Renshon (2007) states that "owning a home is not the same as loving your country". Findings for this research suggest that the interviewees are more proud of living in the United States and enjoying the friendly environment in the metropolitan Portland area than feeling a strong connection with their current neighborhood. Arturo, who has been in the US for the last sixteen years and still remains undocumented, moved from California almost six years ago and commented about owning a home in the Salem metropolitan area and his love for Oregon.

Aquí estamos, aquí es donde tenemos que invertir, mis hijos han nacido y están creciendo aquí. Nosotros vivíamos en California, pero hay mucha inseguridad ahí, yo quiero que mis hijos no se metan con pandillas, en un viaje a Seattle pasamos por aquí y recordé lo que mi abuela nos decía, "donde hay agua hay vida". El rio en la ciudad representa eso para mí, vida; por eso y por la seguridad que todavía existe en Oregon me traje a toda mi familia. Estamos contentos y tranquilos aquí, yo llegando de California compré casa y de verdad que estamos agradecidos con todo lo que este estado nos da.

Here we are, this is where we need to invest, and my children were born and are growing up here. We lived in California, but there is a lot of insecurity there, I 
want my children to not mess with gangs, on a trip to Seattle we came through this city and I remembered what my grandmother told us, "Where there is water, there is life." The river in the city represents that for me, life; that and for the security that still exists in Oregon I brought my whole family. I bought a house as soon as I arrived from California and we are really grateful with everything this state is giving us (Male, Oaxaca, undocumented, restaurant worker).

Community pride was assessed by the following question:

What community means to you?

The place I was born/grew up, my city (where I live now), country I grew up, Country I live, Friends/family, Church, and Neighborhood.

1: Not important at all

2: Somewhat important

3: Important

4: Very important

The majority of the people stated their pride and love for the United States and the city where they reside followed by their love for their family and friends. 


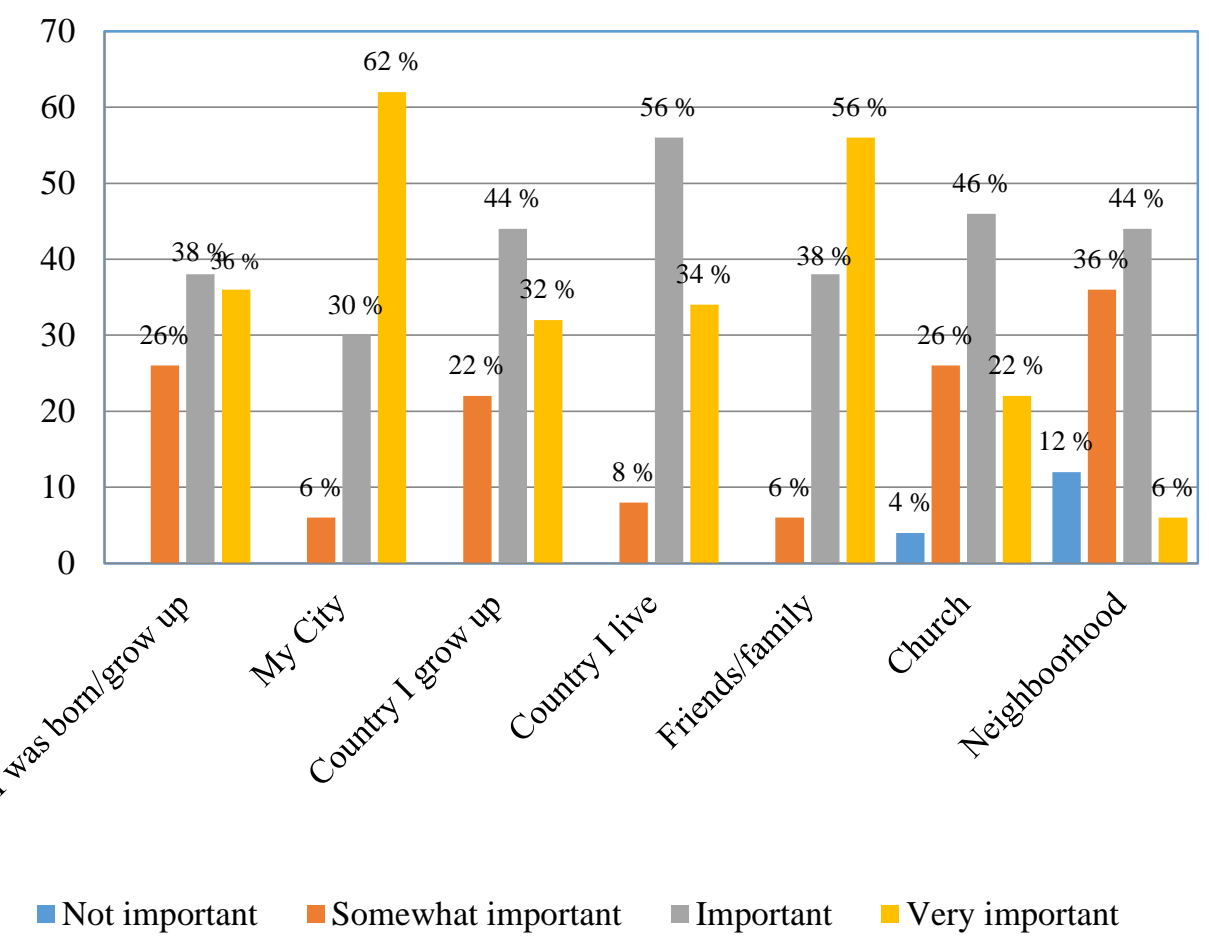

Figure 6.11. What community means to you?

Martin, lived in the Portland metropolitan area for the last nineteen years and once moved to Vancouver, Washington ${ }^{5}$, for six months because his Oregon driver's license expired. Once he was able to get the driver's license from the state of Washington, he returned to Portland, Oregon, the place he calls home.

Yo amo Portland, esta ciudad está enterrada en mi corazón, llevo más de media vida viviendo aquí, no me veo en ningún otro lugar. Me tuve que ir a Vancouver (Washington) para sacar la licencia, pero no me gusto vivir ahí, cruzar ese rio diario no era para mí, solo viví ahí seis meses pero bastaron para darme cuenta

\footnotetext{
${ }^{5}$ The state of Washington is among the only three states that still allow undocumented people to obtain an ID or driver's license.
} 
que es en Portland donde quiero vivir. La gente aquí es muy amable, los güeros te saludan y te respetan, en Vancouver yo no sentí la misma vibra.

I love Portland, this city is buried in my heart, I have lived here half of my lifetime, I do not see myself anywhere else. I had to go to Vancouver (Washington) to get the (driver's) license, but I did not like living there, crossing the river daily was not for me, I only lived there six months but enough to realize that it is in Portland where I want to live. The people here are very friendly, the white people greet you and respect you. In Vancouver I did not feel the same vibe (Male, Mexico City, undocumented, business owner).

Engagement through organizations. Organizations that support the integration of the Latino community in the United States are crucial in building community. People are clearly participating in various organizations, however, the most mentioned places of engagement was with schools, nonprofit organizations, religious organization, and engagement through Hometown Associations (HTA). Table 6.12 shows the frequency of engagement with the different organizations mentioned by the participants.

Schools. Latino students account for up to 21.04 percent $(118,017)$ of Oregon public school students (Oregon Department of Education, 2012). Today, Latinos comprise the second largest group of students in the Oregon public school system. However, Hispanic students struggle to finish high school. According to the state's annual public education report, in the 2011-2012 school year, only 56.5 percent of Latino students graduated in four years (compared to 70.1 percent of their White counterparts ( $\mathrm{p}$. 
20). Different socio demographic variables such as parents' legal status, parents' educational attainment, and family income, among others, play a role in understanding this disparity. Regardless of those results, female interviewees who have children in school tend to participate and volunteer in cultural events at the school. Only two women indicated that this is an opportunity for them to socialize with American mothers, but the majority stated that these interactions are with other Hispanic women. This relationshipbuilding with other Hispanic women was due to these women's choice to participate in immigrant-based institutions, and perhaps related to language preferences. 
Table 6.12. Frequencies of key organizations in interview discussions (50 participants)

\begin{tabular}{|lc|}
\hline Organization & Frequency \\
Pro-immigrant organizations & Total 31 \\
CAUSA & 8 \\
Adelante Mujeres & 5 \\
Hacienda & 5 \\
CIO & 3 \\
PCUN & 7 \\
Liga de Mujeres Votantes de Portland/ & 1 \\
VOZ & 2 \\
Non-profit Organizations & Total 11 \\
UNITEDWAY & 1 \\
MACG & 2 \\
Radio Tonalli & 3 \\
KBOO Community Radio & 5 \\
HTAs & Total 4 \\
Federacion de Clubes Zacatecanos & 1 \\
Asi se siente Puebla (Molcaxac) & 1 \\
HTAs from Oaxaca & 2 \\
Churches & Total $\mathbf{4 0}$ \\
Schools & Total 21 \\
Other & Total 5 \\
Hispanic Chamber & 1 \\
MECHA & 3 \\
Beaverton Task Force & 1 \\
\hline
\end{tabular}

Mexican parents interviewed stated that because more Latino students are in public schools, it is easier for parents to get involved and not feel discriminated against, "Today there are more Hispanics, it is easier for people to engage at their children's school because we are more now" (Male, Jalisco, permanent resident, GED teacher). Elia Rodríguez, a permanent resident from Michoacán who has been in the United States for 27 years, argues that times have changed and because of the increasing number of Hispanics in Oregon, there is a more welcoming environment for Latino parents at schools. 
Yo creo que el tiempo va cambiando, cuando mi hija estaba en la escuela, como yo estaba casada con un anglosajón de cierta manera me veía obligada a cumplir con actividades extraescolares, casi siempre era yo la única hispana en los eventos de la escuela pero ahora con la hija de mi hija he ido a sus eventos y hago una comparación de hace 20 años a este tiempo y hay muchos hispanos y ahora veo que si se involucran más.

I think times are changing. When my daughter was in school, I was married to an Anglo, so in a certain way I felt I was forced to comply with extracurricular activities. I was almost always the only Hispanic at school events but now I have gone to my granddaughter's school events and I do a comparison of 20 years ago to this time and now there are many Hispanics and now I see that they are more engaged (Female, Michoacán, permanent resident, housewife).

Nonprofit organizations. Pro-immigrant organizations are seen as platforms that help to bridge the networks between American society and immigrant communities. For many of our interviewees, belonging to organizations such as CAUSA and the Northwest Treeplanters and Farmworkers United (in Spanish Pioneros y Campesinos Unidos del Noroeste, PCUN) is seen as an opportunity to communicate their needs and look after each other's rights. Maria from a rural community in the state of Oaxaca comments about joining PCUN and how this decision has given her empowerment, not only to leave shyness behind but also to realize the importance of defending Latinos' rights in the United States. 
Cuando yo llegue a Oregon, no sabía leer y me daba mucha pena hablar en público, trabajaba en el campo y fue hasta que me invitaron a participar en PCUN que abrí los ojos y comencé a ver muchas injusticas con la comunidad hispana. Al principio, me gustaba venir a las reuniones de PCUN porque veían que otras mujeres hablaban de los maltratos y discriminación que sufrían en sus trabajos y en sus casas y nuestros instructores nos quitaron la venda de los ojos, nosotras tenemos los mismos derechos que los hombres y no importa tu color de piel, nosotros los mexicanos tenemos los mismos derechos que los Americanos, lo malo es que la gente todavía no lo ve así.

When I came to Oregon, I could not read and I was very ashamed to speak in public. I worked in the fields and it was not until I was invited to participate in PCUN that I opened my eyes and began to see many injustices suffered by the Hispanic community. At first, I liked to come to the PCUN meetings because other women spoke of the mistreatment and discrimination they suffered in their jobs and in their homes and our instructors took away the blindfold, we have the same rights as men and no matter your skin color, we Mexicans have the same rights as the Americans, the trouble is that people still do not see it that way (Female, Oaxaca, visa U holder, cleanliness worker).

Although, I interviewed a couple of people who run or have worked for this type of pro-immigrant organization, they commented that they some perceived sort of corruption while working for these organizations: "after all, the people on the top of these 
organizations look for personal benefits rather that wanting to help the Hispanic community" (female, Puebla, undocumented immigrant, cleanliness worker). Study participants living in the Portland metropolitan area are less likely to be involved with Latino organizations because they state that they are aware of corruption issues, which is broadly discussed in the next section on barriers to civic engagement.

Religious organizations. In Oregon, Latino immigrants have established "their own institutions-churches, clubs, businesses- that provide vital services and create social cohesion in addition to participating in existing organizations that address their needs" (Bussel, 2008). In this regard, respondents stated that going to church has helped them feel more united with other Latino congregants/community members, since most of the respondents who attend church attend the mass in Spanish. Eighty percent of the people interviewed are Catholic. Only three people are protestant and the rest do not consider themselves affliated with any religious category. The majority of the Catholics stated that they became more engaged with religious activities after they came to the United States. This was specially true for those participants who do not have extended family in their communities of residence.

A nosotros nos gusta servir a Dios cuando se puede, mi esposo y yo somos voluntarios en la iglesia y ayudamos en eventos y celebraciones. Yo ya tengo muchos años siendo voluntaria y yo veo esto como un trabajo lleno de responsabilidad aunque no me paguen nada.

We like to serve God when we can, my husband and I are volunteers in the church and help at events and celebrations. I already have many years as a volunteer and 
I see this as a job full of responsibility even if they do not pay anything (Female, Mexico City, undocumented, housewife).

Mexican immigrants, especially from indigenous communities, reproduce and reinforce ties with their communities of origin by organizing their town's religious celebrations in their communities of residence in the U.S. (Massey \& Higgins, 2011). Mercedes, a woman from a rural community in Puebla, states the importance going to church every Sunday and also her responsibility for her home town's religious activities. Me gusta ir a misa, creo que es lo mejor de la semana, trabajamos toda la semana y estamos tan cansados que con ansias esperamos el domingo para ir y ver a los demás paisanos y escuchar de la palabra de Dios. Siempre que festejamos a nuestra patrona allá en el pueblo, también la festejamos aquí. Aquí la fiesta es sencilla pero es una forma de agradecerle por todas sus bendiciones a nuestra comunidad.

I like going to church, I think it's the best moment of the week. We work all week and we are so tired that we eagerly await for the Sunday to go and see other countrymen and listen to the word of God. Whenever we celebrate our patron there in the village, we also celebrate it here. Here the party is simple but is a way to thank him for all his blessings to our community (Female, Puebla, cleanliness worker, undocumented). 
Engagement through Hometown Associations (HTA's). Although the majority of the interviewees have settled permanently in the United States, some are still eager to participate and help their communities of origin, especially if they are from rural areas and still have family members living in Mexico. These interviewees joined Hometown Associations (HTAs) to organize resources for their communities of origin. Figure 6.12 provides an overview of what issues people focused on when they joined an HTA.

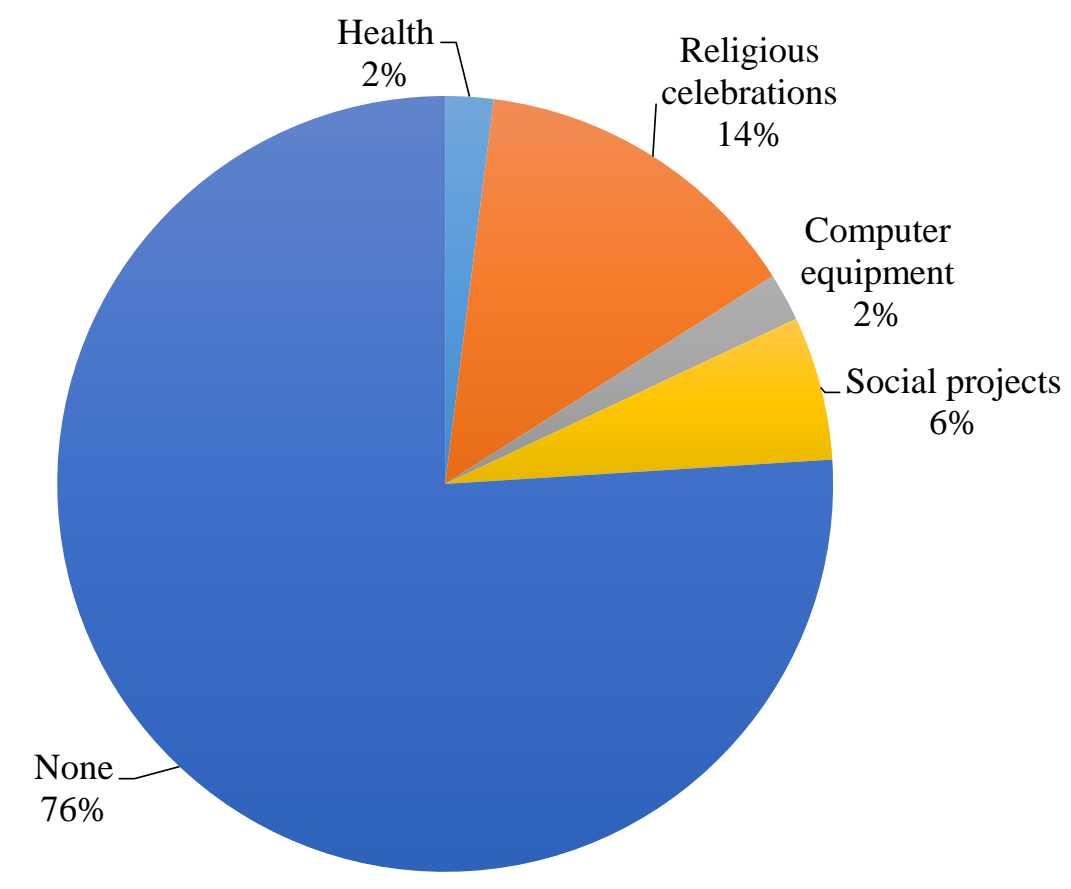

Figure 6.12. Have you participated through an organization to solve a problem in Mexico?

Joining HTAs can also be seen as a way to empower immigrants to collaborate on issues in their communities of residence and a way to help them to overcome discrimination while building civic skills (Markus, Steele, \& Steele, 2000). 
Engagement for Hispanic specific purposes in Oregon. People have also organized for specific issues related to defending Latino immigrants' rights in the U.S., such as obtaining driver's licenses, tuition equity for undocumented students, joining labor unions, and recruiting members for their organizations. Study participants who have legal status are less afraid of joining organizations that support Latinos' rights as well as joining boards and city councils in Oregon. Figure 6.13. shows the issues facing the Latino community in Oregon that interviewees considered to be most serious. There is no doubt that advocating and lobbying for driver's licenses (for people without legal documents in the U.S.) is a number one priority for Latinos at this moment. Figure 6.13 shows the frequency that this issue was brought up by study participants.

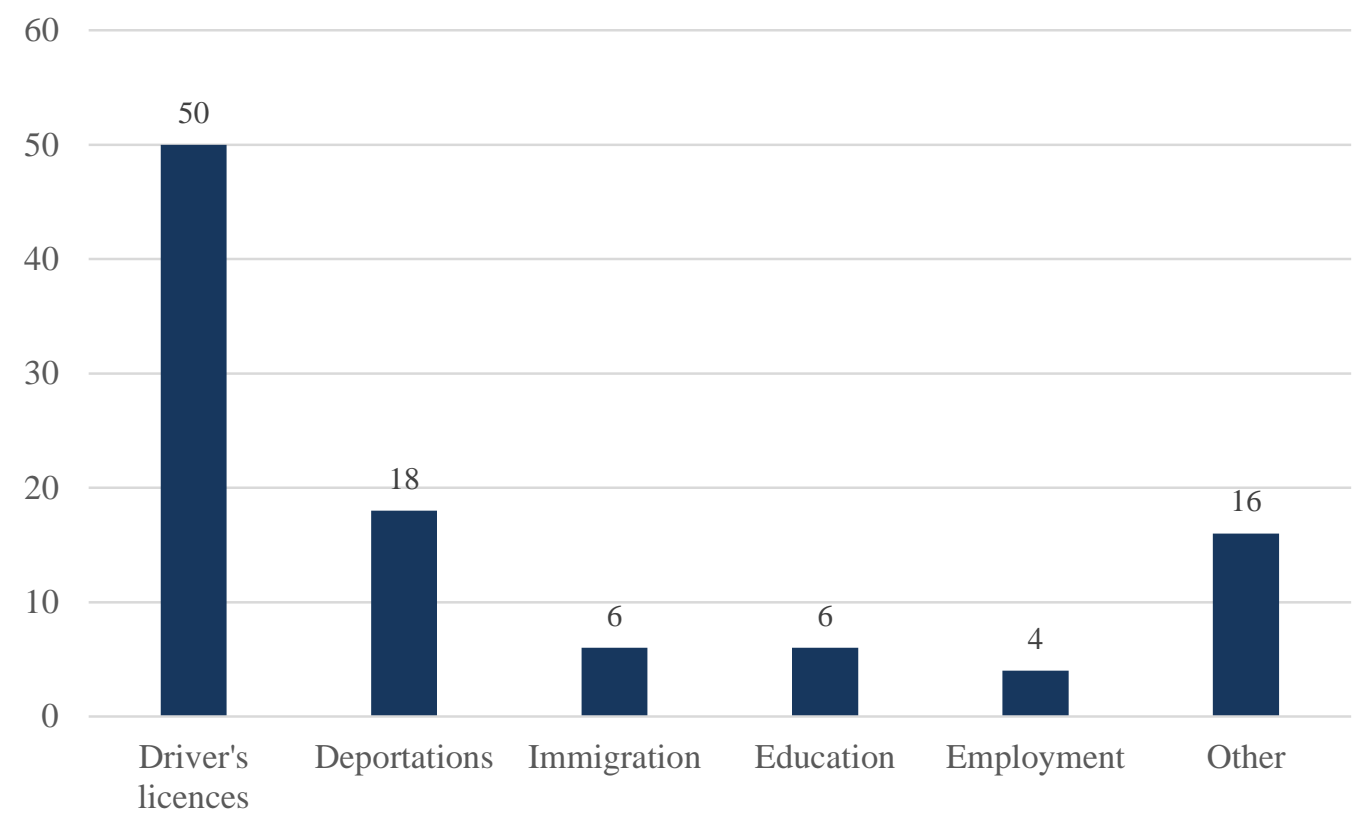

Figure 6.13. Do you know what is the most serious problem in your community of residence? 
Driver's licenses. Fifteen respondents mentioned having participated in meetings regarding issuing driver's licenses to undocumented immigrants ${ }^{6}$, since driving their own cars is the most frequent means of transportation that migrants use to go to work, go shopping, or participate in recreational activities. If immigrants without legal papers cannot apply for a driver's license, many of them may still drive without this document (King et al., 2011). Additionally, since in the United States a state ID or a driver's license is the main form of identification used to access a majority of social services, those immigrants who cannot get one face constraints in accessing those services, affecting the entire family (King et al., 2011). Immigrant organizations such as PCUN, Oregon's Farmworker Union (Northwest Treeplanters and Farmworkers United), Oregon's Immigrant Rights Coalition (CAUSA), Mujeres Luchadoras Progresistas, Hispanos Pros, and Adelante Mujeres, among others, accompanied by U.S. citizens and immigrants have implemented protests and rallies against SB 1080 to support "the restoration of driver's license to all Oregon residents who meet the qualifications for a standard license, regardless of ability to prove citizenship or legal status" (CAUSA, n.d.).

In-state tuition for undocumented students. In 2013, the Latino community in Oregon and their supporters achieved passage of bills that allowed undocumented immigrants to enroll at a university and pay in-state tuition rates, rather than more expensive out-of-state tuition or international student rates (Zheng, 2013). This legislative success has created a climate where the Latino civic organization has gained visibility

\footnotetext{
${ }^{6}$ In 2008, the Oregon SB 1080 established that the Oregon Department of Transportation (ODOT) must require a person to provide proof of both legal presence in the United States and a Social Security Number in order to renew or replace any driver's license, driver's permit, or identification card (King et al., 2011). Since then, pro-immigrant organizations have been implementing marches and activities to support the restoration of driver's licenses for the undocumented immigrant community in Oregon.
} 
regardless of immigrants' legal and economic status. Two of the interviewees participated as organizers in rallies related to this issue.

Labor unions. Latino labor unions are a form of organization designed to protect or fight for worker rights in the U.S. For instance, in cities with large Latino representation such as Washington D.C., Chicago, and Los Angeles, Latinos have been able to create unions that not only look after their employment rights, but also empower their opinionated action and develop leadership skills (Bada, Fox, Donnelly, \& Selee, 2010).

Agriculture is an important industry in Oregon; of the 100,000 farmworkers approximately 98 percent are of Mexican descent (Stephen, 2012). Farmworkers have struggled to claim their workers' rights. In 1985, Pineros y Campesinos Unidos (Northwest Treeplanters and Farmworkers United, or PCUN) was founded to build on the work of United Farm Workers (UFW) and to support and empower farmworkers on issues related to immigration. By 1988, PCUN began focusing its actions on "raising wages for farmworkers" (Stephen, 2012). More recently, PCUN has started to exert political weight at the national level and has increased its advocacy beyond solely the rights of farmworkers, to the mobilization of its members on issues such as immigration reform and paid sick days (Stephen, 2012). One of the participants in this study has actively participated with PCUN. Pedro, a permanent U.S. resident from the Distrito Federal in Mexico who has spent 14 years in Oregon, argues that it is because of the existence of PCUN and the willingness of people to help farmworkers that "today, farmworkers and their families have a decent place to live and better quality of life, their children now go to school and not 
to work in the fields" (Male, Distrito Federal, permanent resident, Building worker including housing remodeling).

Political engagement. The Latino population in the United States actively participated in the presidential elections of 2008 and 2012. The 2008 election featured a more ethnically diverse electorate, with Hispanic citizens representing 7.4 percent of U.S. voters (Lopez \& Taylor, 2009; Barreto et al., 2008). In 2012, 71 percent of the Latino electorate supported president Obama in the presidential election (López \& Taylor, 2012). This voting activity shows the ability of the Latino population to mobilize behind a candidate and become a visible and influential civic body at the national level. This mobilization of Latino voters has not been as easy at the state level, particularly in Oregon.

In 2010 there were 146,000 Latino eligible voters in Oregon (5 percent of Oregon eligible voters), Mexicans represent 76.1 percent of that Latino population (Motel \& Patten, 2012). As mentioned before, a majority of the Mexican population in Oregon lacks legal status, so a very small proportion of Mexicans have the ability to vote in the U.S. However, Mexican immigrants lacking legal status in the U.S may participate politically in other ways, making demands on government, doing activities related to supporting political parties and attending political demonstrations against the government.

Making demands on government. According to the respondents, the "friendly" environment in Oregon helps Mexicans feel more welcome and willing to collaborate and meet with people from diverse backgrounds. This openness, in turn, may help with Mexican integration with American society. Regardless of their legal status, study 
participants said that in case of emergency they would not hesitate to call 911. Marco, an undocumented immigrant from Mexico City who has been pulled over three times and each time given a ticket for driving without a driver's license, shares his experience of dealing with police officers several times and still trusting them in the case of an emergency.

Los policías en Oregon son amables, si nos paran no tenemos más opción que entregar nuestro carro y pagar las multas. Me han quitado mi carro tres veces por no tener licencia, pero no puedo hacer nada, siempre me han tratado bien, ellos quieren que no les mientas, eso es todo, ellos quieren que seamos honestos con ellos y lamentablemente se llevan tu carro pero si tuviera una emergencia y llamo al 911 yo estoy seguro que ellos vendrían a ayudarme sin preguntar mi estatus legal, de eso estoy seguro.

The police in Oregon are friendly, if they pull us over we have no choice but to give them our car and pay the fines. They have taken away my car three times for not having a [driver's] license, but I cannot do anything, they have always treated me well. They want us to not lie to them, that's it, they want us to be honest with them and regrettably they take away your car but if I have an emergency and I call 911, I am sure that they would come to help me without asking my legal status, that's for sure (Male, Mexico City, undocumented, skill and unskilled industrial worker). 
Most interviewees (80 percent) mentioned that they do not know how to complain in regards to government services. Those who are naturalized U.S. citizens or permanent residents mentioned that they did not mind directly calling officials responsible for services. However, undocumented people are afraid of complaining about government services. Instead, study participants without legal documents ask their children to help them navigate local government programs and systems.

When asked about how people in the immigrant community reacted to solving a "public problem" the interviewees said that they obtained help through their personal network of friends, family, or coworkers.

No es que tenga miedo de llamar a alguien, pero no sé a quien llamar, yo le hablo a mi hermana y ella sabe todo, ella me dice que hacer. A veces hablo a organizaciones que ayudan a los Hispanos y ellos siempre saben a quién llamar.

It's not that I am afraid of calling somebody else, but I just do not know who to call, so I will call my sister and she is a very informed person, she will tell me what to do. Sometimes I call organizations that support Hispanics and they always know whom to call (Female, Michoacán, permanent resident, agricultural worker including nurseries and packing).

Political parties related activities. When asked "if you could vote, for which political party would you vote?", three-quarter of study participants mentioned that they would vote for the Democratic Party. Their reasons for supporting the Democratic Party ranged from believing that Democrats are the party that supports immigrants' rights to 
Democrats being perceived as the party that supports more diverse representation in elected officials. (See Figure 6.14.).

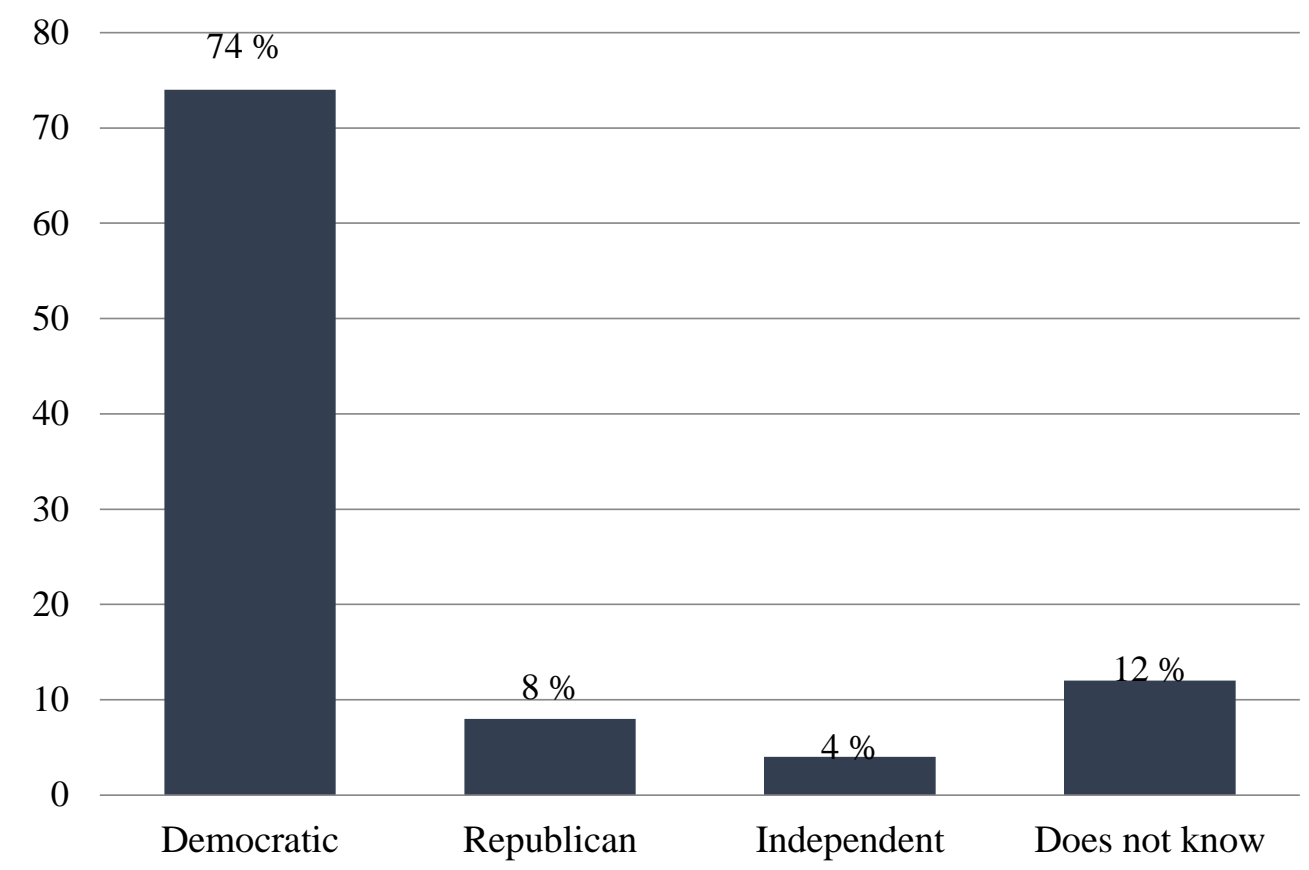

Figure 6.14. If you could vote, for which Party would you vote?

Protests against the Mexican government. As De Graauw (2013) mentions, technology, including transportation and the development of better communication networks, allows immigrants to engage with their home country's political issues. Although the Mexican government gave Mexicans living abroad the opportunity to vote in presidential elections for the first time in history in 2006, only 33,000 Mexicans did so (Voto Extranjero, n.d.). For the 2012 presidential election in Mexico, 40,714 Mexicans voted from abroad including 29,348 who were residing in the United States (Meléndez Yúdico, 2012). The main reason Mexicans residing in the US did not vote in the Mexican presidential election was the lack of voting cards and the requirement that to obtain 
voting cards, citizens had to physically return to Mexico, which many were unable to do. Additionally, the majority of the people interviewed for this study do not have their Mexican national voter registration $\operatorname{card}^{7}$ ( 95 percent), which is required to request an absentee ballot. Also, from the interviewees' point of view, many Mexicans living in the US do not trust the Mexican government enough to even spend time requesting the absentee ballot because "all the elections in Mexico are bought and we already know who is going to be our next President" (Sol, undocumented, cleanliness worker).

Interviewees may not participate in electing the Mexican president, but current (political) events and the increase in corruption in Mexico has sparked anger and discontent among the Mexicans living abroad, including those who reside in Oregon. Protests against the Mexican federal government have been increasing, as Mexican government corruption have increased. Recent acts of repudiation on the part of the Mexican government in cases such as Tlataya, Ayotzinapa, and Apatzingan ${ }^{8}$ have also galvanized the Mexican community to unite and create organizations which aim to show their discontent to Mexican authorities. Sixty percent of interviewees have participated in this political engagement in some capacity, including active involvement with political organizations. Interviewees believe it is their duty as Mexican citizens to demand better government, "for such a beautiful country where you have everything, but the government does a very poor job and we are forced to leave and live far away from our loved ones" (Female, Veracruz, undocumented immigrant, restaurant worker).

\footnotetext{
${ }^{7}$ A voter ID card that allows Mexican citizens eighteen years and older to cast a ballot for any Mexican election. This voter ID card also allows Mexican citizens to vote for presidential elections and for some state governors (INE, n.d.)

${ }^{8}$ Armed attacks by the Mexican government on protesters that have resulted in death and disappearances.
} 
Table 6.13. presents a summary of the patterns of engagement of the respondents in their communities of residence. The interviewees showed optimism and mentioned that they see the US system as fair and reliable. Only a few study participants have directly participated in politics, several have participated in volunteer work, while others have only observed family members and friends doing so. The people that participated had interaction with schools, employment agencies, religious institutions, pro-immigrant and government organizations. In general, interviewees with more US civic participation had higher levels of educational attainment, better jobs, and better English language skills. 
Table 6.13. Patterns of civic engagement

\begin{tabular}{|c|l|}
\hline Path & \multicolumn{1}{|c|}{ Type of engagement } \\
\hline $\begin{array}{c}\text { Engagement through community } \\
\text { pride }\end{array}$ & $\begin{array}{l}\text { Volunteer for community activities } \\
\text { Participation with issues related to } \\
\text { community of residence }\end{array}$ \\
\hline Organizations & $\begin{array}{l}\text { Religious } \\
\text { Non-profit organizations } \\
\text { Schools } \\
\text { Hometown Associations (HTAs) }\end{array}$ \\
\hline Engagement for Hispanic related & $\begin{array}{l}\text { Driver's licenses } \\
\text { In-state tuition for undocumented students } \\
\text { purposes in the US }\end{array}$ \\
\hline Political engagement & $\begin{array}{l}\text { Making demands on government } \\
\text { Political party activities } \\
\text { Protesting Mexican governmental } \\
\text { practices }\end{array}$ \\
\hline
\end{tabular}

\section{Barriers to Mexican immigrants' civic engagement}

For the purposes of this research, there are six main factors that the Mexican immigrants interviewed see as barriers to engagement, which are described next.

Do not know how to be involved. In Oregon, regardless of their legal status, the majority of the people interviewed for this study have settled permanently in the US and feel like they can call Oregon their home. Interviewees said that Oregon, and the United States in general, has given them the opportunities that they were denied elsewhere. While interviewees love and respect Oregon, their biggest concern is lack of knowledge and information about how to be involved with broader society. This includes a persistent 
idea that immigrants are in the United States to work and not necessarily to be integrated or engage with the broader society.

Vine a los Estados Unidos cuando tenía diecisiete años, ahora tengo 45, he estado aquí más de la mitad de mi vida. Este país me ha dado todo, soy mexicano no lo niego pero a veces siento que quiero más a Estados Unidos. Conocí a mi esposo aquí, mis hijos han nacido aquí y mi vida está aquí.

I came to the United States when I was seventeen, I am 45 now, I have been here more than half of my life. This country has given me everything, I am Mexican and I do not deny it, but sometimes I feel like I love the United States more. I met my husband here, my children were born here, and my life is here. (Female, Jalisco, naturalized US citizen, Social Worker).

Despite this, some of the respondents (especially those who live in non-urban areas) stated that they still live somewhat isolated from US society. The places for interaction with American society and immigrants from other countries include markets, parks, malls, and schools, however, these spaces do not ensure that dialogue with other cultural groups is facilitated. Many interviewees lack knowledge of services and family or cultural events in their communities of residence. However, when asked if they would be interested in attending more events, most of the study participants said yes. Also, ten participants stated that pro-migrant organizations and local governments should take responsibility for publicizing this type of information so that the Latino community can better integrate with their American communities. 
Concern about getting into trouble. At the national level, even some immigrants with permanent residency still fear that participating in protests or marches may affect their legal status and cause their deportation. These fears of deportation constrained them from integrating in their U.S. communities (Gonzales \& Chavez, 2012). In the particular case of Oregon, some of the participants who are permanent residents or naturalized U.S. citizens said that they prefer not to participate in protests and marchers because they do not want to get into trouble and are concerned about the police reaction to them participating in these kinds of events.

Those study participants with undocumented status stated that they avoid participating in marches, rallies or demonstrations. Nevertheless, a large proportion, around 60 percent, of the undocumented interviewees participated in the marches and protests of 2006. Interviewees' main reason for participating in the 2006 marches and protests was that thousands of people, regardless of their legal status, were in the streets and they felt the community support was enormous, even from the American society. Since these mobilizations ended, interviewees are back to feeling fearful of attending political demonstrations since the police may apprehend them and this may cause their deportation.

It is worthy to mention that the media in Spanish, or so called non-mainstream media, also played an important role in catalyzing the participation of such a large number of people in the 2006 protests. Felix et al., (2008) argue that the media in Spanish greatly covered the "Gran Marcha in Los Angeles" while the mainstream media did not pay much attention to the protests and political events (Felix et al., 2008). Don Nicolas, an immigrant from the Distrito Federal who has been in the U.S. for 30 years argues that the 
radio was a tool to awaken the Mexican immigrants in 2006 that "it was the time to leave the shadows."

Nosotros nos enterábamos de los eventos y las marchas a través de la radio, los locutores nos invitaban a participar y recuerdo bien que nos decían que era el momento de salir de la sombra, que ya somos muchos mexicanos en este país y que no tuviéramos miedo, mi familia y yo fuimos a la marcha que hicieron en Portland, había mucha gente, no había antes visto a tantos mexicanos reunidos como ese día.

We found out about the events and marches through the radio, the radio announcers invited us to participate and I remember well that they said it was time to get out of the shadows, we are already many Mexicans in this country and that we should not be afraid. My family and I went to the march they held in Portland, many people, I had never before seen as many Mexicans gathered like that day (Male, Mexico City, naturalized U.S. citizen, business owner).

\section{Intrinsic Issues (time, education, language, social and legal status). While}

slightly more than 70 percent of the study participants are involved in community groups of some type, time, money, language restrictions, level of education, and issues with transportation were the most mentioned intrinsic barriers (See Figure 6.15.). Fifteen interviewees said that they do not possess the time or money needed to freely volunteer or participate in events. Also, some people stated that they do not feel comfortable 
approaching Americans or public officials in general because of language barriers and legal status.

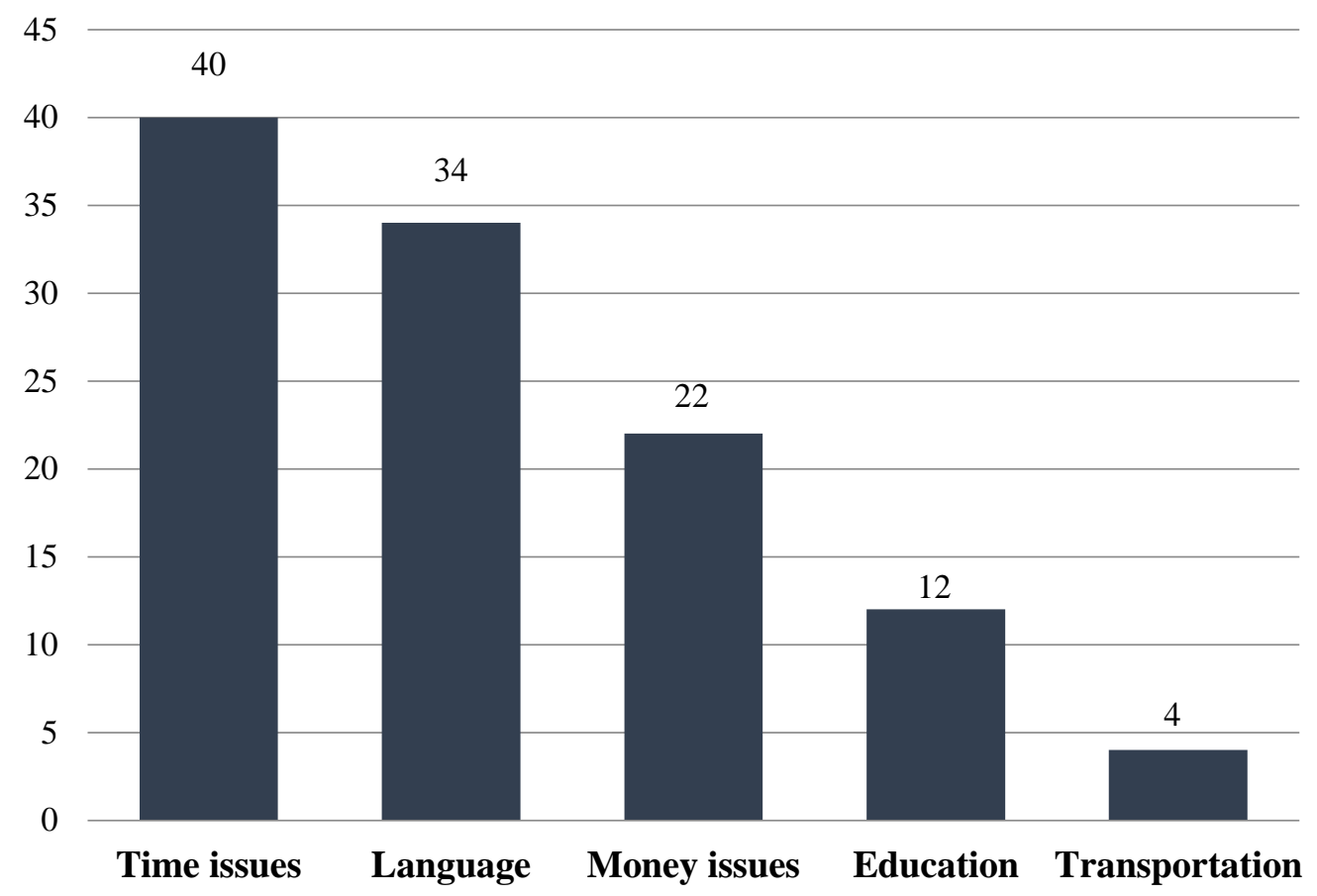

Figure 6.15. Barriers to civic engagement most mentioned by the interviewees

Time issues, low levels of English, and money issues appear to be the most visible barriers that constrain immigrants from participating civically in their communities of residence. Mexican immigrants face many barriers in addition to language because many not only did not attend school in the U.S., but also only attended school in Mexico for a limited time. Hence, many Mexican immigrants lack information about how different the American political system or American civic culture is from that in Mexico. This impedes people from fully engaging in their American communities of residence.

Entiendo poco inglés, la verdad es que no lo práctico y con gestos o señas me comunico con mi patrona pero para cosas del trabajo solamente, de verdad 
que no me siento en confianza para hablar en inglés con alguien más que no sea mi patrona.

I understand little English, the truth is that I do not practice it, with gestures or signs I communicate with my employer but for work staff only. I really do not feel confident to speak English with someone else other than my boss (Female, Puebla, undocumented, sanitary worker).

\section{Bad experiences with government and non-governmental entities. Some}

participants stated that they have experienced acts of corruption in Mexico or in the U.S. This is reflected in their mistrust of the Mexican and/or U.S. government, as well as of the majority of Latino organizations that are established in Oregon.

Mistrust in the Mexican government. Olvera (2009) states that there is a "notable absence of participatory traditions in Mexico to promote the deepening of democracy" ( $p$. 4). This author points out that the lack of civic participation within Mexican society can be explained and understood historically by looking at how the state has governed and how the levels of corruption have increased. Barriers become evident when studying Mexican societal patterns of participation and willingness to participate civically. Some of these barriers are generated by the authorities themselves. Unfortunately in Mexico, due to high levels of corruption, the general sentiment exists that people do not have a voice in public affairs. This statement was echoed multiple times by study participants who also mentioned that Mexicans have immigrated to the United States because of the ineffectiveness of the 
Mexican government to provide for its people. All the participants expressed mistrust in the Mexican government.

Mistrust in the U.S. Federal government. Interviewees who have had bad experiences with government bodies in Mexico are less likely to be involved or willing to learn about politics in the United States. While trust in the government appears to be an important facilitator of civic engagement (Barnes \& Mann, 2011), study participants mistrust in the Mexican government did not seem to prevent them from civically engaging in their communities of residence. It did not appear to be the case with the people interviewed due to their low levels of trust in the Mexican government. Although all interviewees do not trust the Mexican government, they stated some disenchantment with the U.S. federal government due to its failure to pass comprehensive immigrant reform. It is noteworthy to mention that five study participants mentioned that local governments do a good job and that "they deserve all our respect, they win elections in a clean way but the federal government is a mess and they only use the Latinos to win the Presidency and then they forget about us".

Mistrust of pro-Latino organizations in Oregon. In response to my question regarding trust of local pro-Latino organizations, 30 of the study participants shared their mistrust of pro-Latino organizations. While some have had negative experiences with these entities others have not reached out to them, but still do not trust them. Twenty four times during the interviewing phase, corruption in these organizations was raised as a serious issue. Participants also mentioned that these organizations are operated by people who are born in the U.S. from Mexican parents, and therefore do not know what the actual needs 
of the first generation immigrants are. Table 6.14. provides a sample of participants' expressions of mistrust of government and non-governmental entities. 
Table 6.14. Participant's discussion about mistrust in Latino organizations

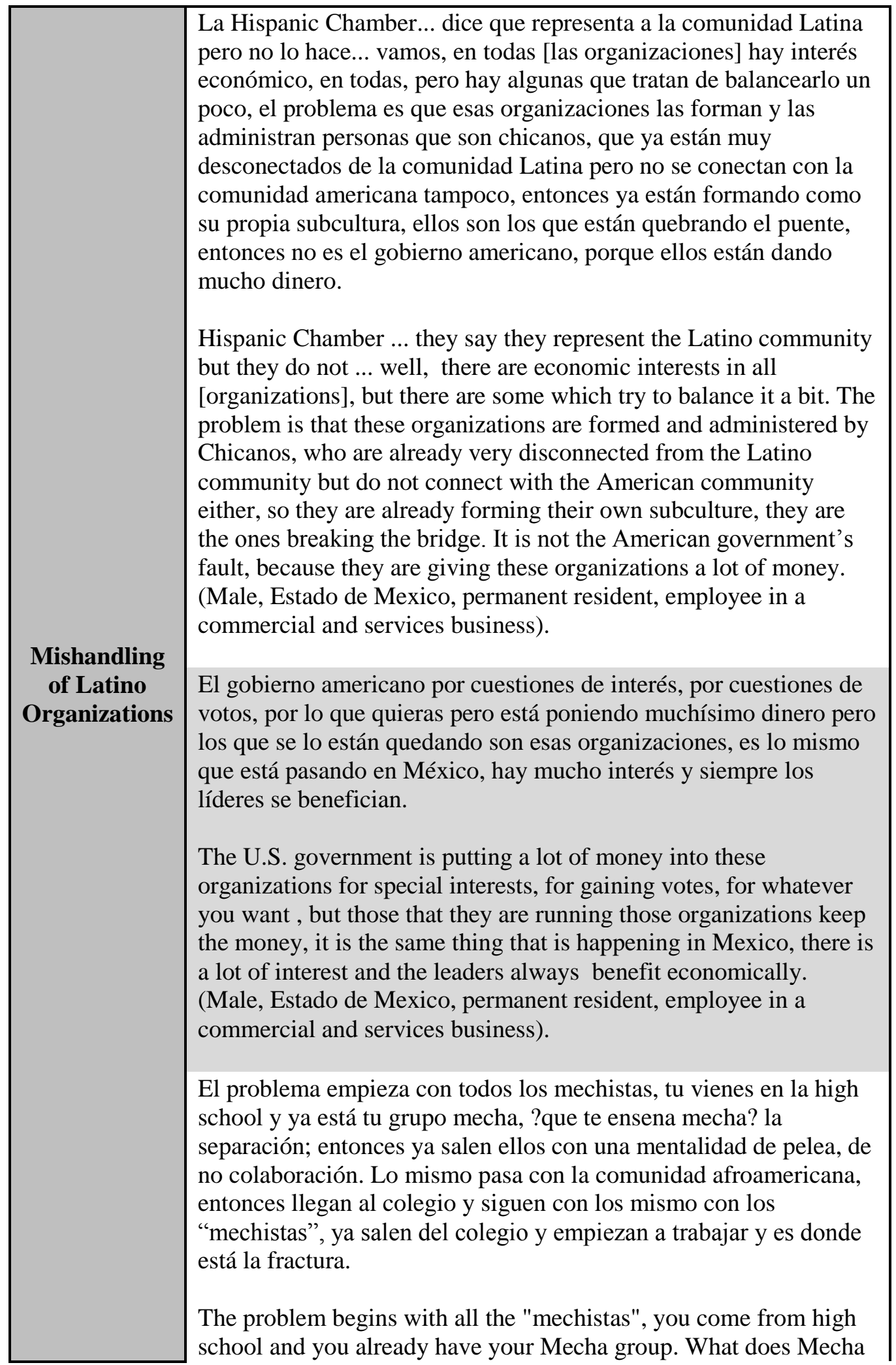


teach you? The separation; and then they leave with a fighting mentality, not collaboration. The same goes for the black community, then they come to school and continue with the same, with the mechistas, and leave school and start working and this is where the fracture is (Male, Estado de Mexico, permanent resident, employee in a commercial and services business).

Los dreamers, sin tanto bla bla sin tanto presupuesto han hecho mucho por la comunidad. Las organizaciones solo se roban el dinero.

The dreamers, without much talking and without much budget have done much for the community. Organizations only steal the money (Female, Distrito Federal, undocumented, cleanliness worker).

Lo que las organizaciones hacen es un doble robo, roban no solo al gobierno americano que les da dinero si no roban a la comunidad Latina porque no hacen su trabajo. Solo se quedan con todo el dinero y saquean a los dos gobiernos.

What organizations do is a double robbery, they rob not only the American government which gives them money but they also rob the Latino community because they do not do their work. They only keep all the money and loot from the two governments (Female, Distrito Federal, permanent resident, business owner).

No sé si de verdad den apoyo es solo propaganda política porque no vemos ningún progreso en nosotros.

I do not know if they really give support or if it is just propaganda because we do not see progress for us (Female, Puebla, undocumented, cleanliness worker).

Si en México, yo me quejaba de los sindicatos, las organizaciones aquí son lo mismo, son para dividir, crear bandos y controlar a los latinos. Voz, Causa, los jornaleros tienen su grupo de gente que supuestamente luchan por una causa común, cuando están tratando de llegar a la meta, se acaban entre ellos y persiste la división... pero cada una de esas organizaciones recibe dinero, son sindicatos mexicanos, así tan vil.

If in Mexico I complained about unions, the organizations here are the same, they are divisive, they create factions and control the Latinos. VOZ, Causa, and the laborers [PCUN] have their groups of people who allegedly fight for a common cause, when trying to reach the goal, they attack each other and the division continues ... but each of these organizations receives money, they are Mexican unions, as vile as that (Female, Distrito Federal, undocumented, cleanliness worker). 


\section{Thinks his/her opinion does not matter for the American society. Seventy}

percent of the interviewees stated that they have faced discrimination in their work places. The following participant, an undocumented person who has been in the country for 18 years, highlighted the injustices that her husband encountered while working at a Chinese restaurant.

Mi esposo ha trabajado ahí por cinco años, no lo corren porque trabaja duro, el chino [the owner] abusa de él, sabe que no tiene papeles y lo pone a trabajar de mas, casi siempre trabaja una hora más al día y esa hora no se la paga, porque no tenemos papeles a donde vayamos a trabajar van a abusar de uno.

My husband has worked there for five years, they do not fire him because he works hard, the Chinese [the owner] abused him, he knows that he has no papers and makes him work more, he often works one more hour per day and that hour is not paid, because we do not have papers wherever we go to work, they will abuse us (Female, Chiapas, undocumented, cleanliness worker).

Other participants highlighted the fact that white Americans are better bosses than people of other nationalities, including Mexican businesspeople, who are more prone to short undocumented people on their pay.

Similarly, discrimination in services and stores was mentioned by ten study participants. Five participants stated that they have faced discriminatory practices in stores. Another two interviewees stated that they were mistreated while attending a 
Parent Teacher Association meeting and two mentioned that they were also mistreated while giving birth at local hospitals. Twenty participants mentioned practices of racial profiling by the police. However, it is noteworthy to mention that participants feel confident that Americans who provide face-to-face services are nicer and try to help them more, even when interviewees have limited English language ability, than Mexicans working at the Mexican consulate in Portland.

The perception of discrimination among study participants plays a role in their feelings of inferiority in their American communities, and therefore represents a constraint to civic engagement. Similarly, 30 percent of the sample commented about isolation being a tremendous barrier for the Mexican community to civically engage with their communities of residence, "we are isolated, this is like a golden cage, you work and work and then go to the mall and spend time with the family on weekends, we do not spend time with more people but with our own" (Female, permanent resident, Michoacán, agricultural worker including nurseries and packing).

Do not value civic engagement. In Mexico "volunteering is not considered to be part of the national culture and it occurs mainly in informal settings, where it is seen not so much as a voluntary action but rather as part of a moral and/or religious obligation" (Dekker \& Halman 2003). Therefore, 80 percent of study participants, those from rural areas in Mexico, stated that they feel obligated to contribute to the religious ceremonies of their home towns. Twenty participants highlighted that as part of the Mexican culture, people do not want to be involved in something or volunteer their time if they do not see a tangible product out of it. Table 6.15. showcases various participants' perspectives on 
cultural differences as an important barrier to civic engagement in their receiving communities. 
Table 6.15. Participants' discussion around cultural differences as a barrier to civic engagement

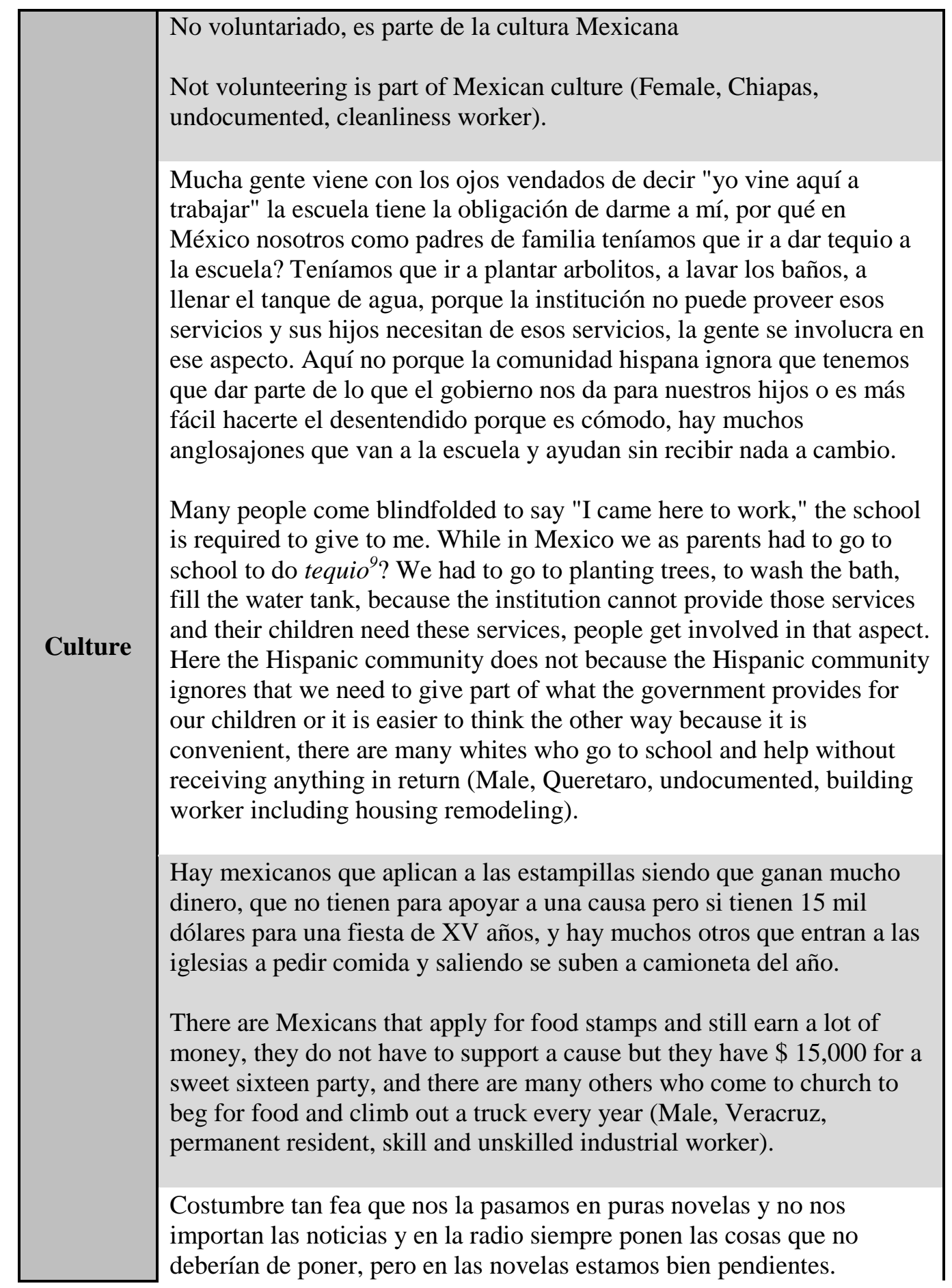

\footnotetext{
${ }^{9}$ Tequio is a type of community work for collective benefit, community members contribute materials or labor to this effort.
} 
An ugly habit that we have is that we spend our time watching soap operas and do not care about the news and on the radio they always put the things that they should not put, but we are always paying attention to soap operas (Female, Puebla, undocumented, cleanliness worker).

Somos bien dejados, ahorita te digo si si si pero cuando me vas a traer no tengo tiempo. Ponemos tanto pretexto, al rato pasa mi novela y como la voy a dejar de ver o mi programa del chavo o de la Rosa de Guadalupe, porque a veces si tenemos tiempo pero no queremos ir.

We have the tendency to delay things, right now I say yes yes yes but when are you going to pick me up I do not have time. We make up many pretexts, "I have to watch my soap opera, how can I not see it?" or my Chavo [del ocho] program or the Rosa de Guadalupe [program], because sometimes we do have time but do not want to go (Female, Veracruz, undocumented, restaurant worker).

Si les dicen que cada vez que vayan les van a dar comida y ropa y ahí están, entonces si estamos hasta toda la familia, entonces si estamos al pendiente.

If you tell them that every time they are going they will give them food and clothing, then they will be there, even the whole family. Then we will be aware (Female, Puebla, undocumented, cleanliness worker).

La pasividad, la inactividad, el no hablar, el no manifestarse, el no saber cuánto valemos ni hacer valer nuestras contribuciones como pagadores de impuestos, no es tanto la falta de empleo y la falta de papeles, es el permitir que hagan esa manipulación mental, nos trajimos el rancho para acá y cambiamos poco, nos trajimos al Komander, nos trajimos la novela y la corona, pero no cambia la mentalidad y eso es lo que quiero cambiar con mi clase.

Passivity, inactivity, not to speak up, not protesting, not knowing how much we are worth or enforcing our contributions as taxpayers, it is not so much the lack of employment and lack of papers but rather allowing themselves to be mentally manipulated, we brought the ranch here and we change a bit, we brought the Komander ${ }^{10}$, we brought the soap opera and the Corona, but that does not change our mentality and that is what I want to change in my class (Male, Distrito Federal, permanent resident, teacher).

\footnotetext{
${ }^{10}$ Komander is a Mexican singer who signs about the life of Mexican drug traffickers and other hitmen.
} 


\begin{tabular}{|l|l|}
\hline Es cultural, en la fábrica donde yo trabajaba me canse de poner posters \\
de que fueran a las machas por las licencias y nunca llegaron, había un \\
evento para hablarles de migración y no llegaban, unos decían que no \\
podían porque tenían un bautizo, otros que no sabía si podría llegar \\
porque iba a ir a un baile y no sabían si se iban a levantar y como ellos \\
es la mayoría de la gente y mientras la TV y la radio sigan controlando \\
esa mentalidad idiota, los hispanos aquí no vamos a cambiar. \\
It is cultural, in the factory where I worked I got tired of putting posters \\
to invite people to go to the marches demanding licenses and they never \\
went. If there was an event to talk about migration and they did not \\
come, some said they could not because they had a baptism, others did \\
not know if they could because they were going to a dance and did not \\
know if they were going to wake up and the majority of people are just \\
like them. While TV and radio continue to control this idiot mentality, \\
Hispanics here will not change (Female, Distrito Federal, \\
undocumented, cleanliness worker). \\
Me gustaría que más padres de familia vinieran a quejarse de que no les \\
gusto, pero es tan triste saber que ningún hispano sabe que hay derechos \\
que pueden venir a reclamar, no les interesa, no queremos conocer \\
nuestros derechos para no movernos. \\
I wish more parents came and complained about what they did not like \\
but it is so sad to know that no Hispanic knows that there are rights that \\
they can come to complain about, but they do not care, we do not want \\
to know our rights to not move (Male, Jalisco, permanent resident, GED \\
teacher). \\
Queremos todo pero no hacemos nada. \\
We want everything but do nothing (Male, Zacatecas, permanent \\
resident, agricultural worker including nurseries and packing).
\end{tabular}

Table 6.16. summarizes the reasons given by the respondents about why people do not participate civically in Oregon. 
Table 6.16. Why do people not participate?

\begin{tabular}{|c|c|}
\hline Reason & Cause \\
\hline Do not know how to be involved & Lack of information \\
\hline Concern about getting into trouble & $\begin{array}{l}\text { Affect immigration status } \\
\text { Legal status } \\
\text { Discrimination }\end{array}$ \\
\hline $\begin{array}{l}\text { Intrinsic Issues (time, education, } \\
\text { language, social status) }\end{array}$ & $\begin{array}{l}\text { Time } \\
\text { Money } \\
\text { Language } \\
\text { Education } \\
\text { Legal status } \\
\text { Lack of transportation }\end{array}$ \\
\hline Negative feelings about politics & $\begin{array}{l}\text { Bad experiences with government entities/ } \\
\text { organizations in the U.S. and in Mexico } \\
\text { Prejudices about corrupt and inefficient } \\
\text { governments in the U.S. and in Mexico }\end{array}$ \\
\hline Do not feel valued & $\begin{array}{l}\text { Their opinion does not matter for American } \\
\text { society } \\
\text { Discrimination } \\
\text { Isolation from American society }\end{array}$ \\
\hline Do not value civic engagement & Cultural Perspectives \\
\hline
\end{tabular}

\section{Summary}

Overall, many Mexican immigrants have settled permanently in Oregon and are grateful for US. society. Many, regardless of their legal status, are interested in issues that are important to the broader society. However, immigrants incorporate at different levels (Portes \& Rumbaut, 2006). Those who have had fewer opportunities for education and work in low wage jobs face discrimination and marginalization that detracts from their integration in US communities. Immigrants are interested in engaging with their communities of residence, however, they argue that there is no information about how to become engaged and there are no mechanisms to increase their education on U.S. history and civic issues. 
On the other hand, nonprofit organizations, schools, and churches are anchors which provide avenues to engage Mexican immigrants in Oregon society. The high levels of corruption in Mexico have organized Mexicans residing in Oregon to hold protests and participate in political activities which fight against corrupt practices. These are places that provide Mexican immigrants with security and comfort to become more engaged. Similarly, Hometown Associations (HTAs) provide immigrants with social and political knowledge and information about Mexican current affairs. This engagement with fellow nationals to encourage the development of their home communities can be seen as a form of immigrant empowerment which allows for collaboration on issues such as drivers' licenses, tuition equity, and education reforms, among others. This civic engagement can be translated to immigrants' communities of residence, and ultimately benefit US communities as well. 
"If Americans have difficulty understanding and appreciating their country, how can we expect new immigrants to fare much better?" (Renshon, 2007)

\section{Chapter 7 Conclusion}

Drawing on a mixed method research design, the preceding chapters explored the factors that influenced the level of civic engagement among the Mexican immigrant community in Oregon as well as with their communities of origin. I identified the facilitators and barriers that Mexican immigrants experience in becoming integrated in Oregon's social, political, and economic affairs. I also developed an understanding of the local contexts in which Mexican immigrants live and participate in the metropolitan areas of Portland and Salem.

Most research in social sciences addressess the study of migrant transnationalism and political engagement by pointing out that participation in one nation comes at the expense of participation in the other (Massey \& Sanchez, 2010). Instead, my work adapts and expands on the trasnational civic engagement framework (Paasche \& Fangen, 2012) to prove that the engagement of immigrants with their communities of origin is complemented by, rather than decreased by, their engagement in their communities of residence. The adaptation of this framework provides an opportunity for policymakers and researchers alike to better incorporate the engagement of Mexicans from indigenous backgrounds as well as those who lack of legal status, characteristics of the majority of Mexicans residing in Oregon.

This Chapter provides a summary of key findings followed by a discussion of the limitations of this study. The chapter concludes with a discussion of implications for future research. 


\section{Discussion}

Today, up to ten percent of the Mexican-born population resides in the United States; more than 33 million people of Mexican descent live in the U.S. (GonzalezBarrera \& Lopez, 2013; Ortiz Gabriel, 2012). Until 2006, more than 600,000 Mexicans tried to make it into the U.S., both legally and illegally, many risking their lives (Ortiz Gabriel, 2012). Even if "the incentive to migrate will vary across individuals according to differences in their expectations" (Hanson, 2006), scholars find that the primary reason is economic, however "geographical proximity allows unauthorized migrants from Mexico to move to the United States easily" (Hanson, 2006, p. 872).

Mexicans living in the U.S. undergo cultural adjustment to live within a different culture, with different customs, in a country whose history is considered multicultural (Sánchez Díaz de Rivera, \& Hernández Rojas, 2012). Some Mexicans experience a cultural manifestation of globalization and transnationalism, which allow migrants to be incorporated in networks and maintain links with their communities of origin (e. g. remittances sent). Mexican migrants often work and live in immigrant enclaves, even if they maintain their ties with their communities of origin in Mexico. Mexican migrants have become active civic members of their communities of residence across the United States (Stephen 2007; DeSipio, 2011; Escamilla-Hamm, 2009; Fox, 2010; RiveraSalgado, Gaspar-Bada \& Escala-Rabadan, 2005). In the following section, I summarize factors that influence social, political, and economic engagement in Mexico and in the United States.

Mexican immigrants in Oregon are civically engaged with their commuities of origin but live paralell lives that complement their desire and engagement in differet 
aspects of their communities of residence (Canedo Vasquez, 2008; Carlsen, 1999;

Stephen, 2007). In terms of the transnational civic engagement of Mexican immigrants, consistent with the literature, the findings suggest that people from indigenous backgrounds and from rural areas are more engaged with their communities of residence than those who come from urban areas in Mexico (Canedo Vasquez, 2008; Carlsen, 1999). However, people from urban areas, with higher educational attaitnment, with higher income, and with legal status are more economically and politically engaged in Oregon. Also, consistent with the literature, men are more engaged with their communities of origin than women, probably due to the fact that historcally only the participation of men in hometown associations (HTAs) has been accounted for, until more recently when women's voices have been incorporated into transnational engagement research (Canedo Vasquez, 2008; Carlsen, 1999; Stephen, 2007). On the other hand, women are more engaged in their communities of residence due to more flexiblility with their time and through performing their roles as mothers by engaging with their children's schools (Ainslie, 2014; Seif, 2009). Also, immigrants who have been in the United States for over ten years and planned to stay permanently were more likely to be civically involved than others. Lastly, also consistent with the literature, English language profiency was associated with higher levels of civic engagement in this study (Jones, 2013).

In contrast to the zero-sum perspective, this study suggests that Mexican immigrants are actively shifting from one national context to another, depending on where the need is higher. If, for instance, a school in the community of origin is in need of a remodelation or computer equipment, migrants in the U.S. will direct their collective 
action to that need. Similarly, if legislation impedes undocumented people to obtain a driver's license in the United States, migrants will take action by lobbying or taking to the streets. In either case, political and social institutions in both countries should promote, not hinder, such activities.

In the following section I summarize the factors and the barriers that influence civic engagement with Mexican immigrants' communities of origin and with their communities of residence among interviewees for this research.

Factors influencing civic engagement. The interviews conducted for this project allowed for an assessment of the impact of civic engagement among Mexican immigrants in Oregon and in their communities of origin as well as their integration within the U.S. communities where now they reside in the upper northwest quadrant of the state of Oregon.

Regardless of limited time, lack of economic stability, and lack of information, Mexican immigrants participate in community affairs. They participate in community organizations, religious groups, schools and transnational organizations, also known as Hometown Associations (HTAs), which work to improve the economic development of immigrant's communities of origin. Mexican immigrants are also looking for transparency and accountability in local and national Mexican politics, although, these transnational organizations are also becoming more involved in civic and political affairs in the United States such as advocating for the rights of Mexican immigrants in the United States and lobbying to obtain driver's licenses for undocumented people.

This dissertation serves as evidence for the need to re-conceptualize the study of civic engagement beyond legal status. Mexican immigrants are politically engaged in the 
United States, and even though the large marjoirty of the Mexicans in Oregon are undocumented, they have succesfully driven the passage of policies such as tuition equity in 2013 and lobbied to increase the minimum wage and for comprehensive immigration reform.

In this sense, the agglomeration of Mexican immigrants in cultural organizations moves beyond sending remittances to family members towards investing in Mexicosponsored 3 for 1 projects. The interviewees who are part of these organizations have a strong desire to affect politics in Mexico, which is challenged by the nonpolitical status of nonprofit organizations.

This research presents serious empirical and conceptual challenges to previous work on Latino civic engagement (e.g., Putman, 2007). Those who have low levels of educational attainment, lack of legal status, and come from an indigenous background present high levels of civic engagement in both nations. These findings argue that immigrants' interest and engagement in home-country political issues enhances their political participation in the United States. Immigrants' participation in civic affairs teaches them to be more aware of current events in Mexico and in the United States, as well as the strategies to work collectively, which can be translated into skills for political and policy ends.

On the other hand, Mexican immigrants residing in Oregon do not need to have legal residency to formally participate in community and political affairs. In fact, civic affairs are performed more often than participation in formal politics, because, as my interviews revealed, Mexican immigrants, probably due to the high levels of corruption 
within the Mexican government, often perceive politics as confusing or as part of a corrupt system.

Religious organizations provide "immigrants with an institutional point of entry into American political life" (De Graauw, 2013). As suggested by Stepick et al. (2009), churches seem to be an excellent mechanism, and in some case the most reliable, for Mexican immigrants' social engagement in their new communities of residence. People from rural communities especially revere their saints and in most cases are involved in sending money to celebrate religious festivities in their home communities. When the community that resides in the United States is considerably large, they usually recreate these religious festivities in the United States as well.

In this sample, labor unions did not play an important role in civic engagement. At the national level, unions have been considered as mobilization mechanisms for immigrants, including undocumented immigrants (Milkman, 2000; Terriquez, 2011). There were not enough respondents in this sample who participated in unions to support this claim, however organizations like PCUN were mentioned as facilitators of political engagement. Similarly, pro-immigrant Latino organizations also provide immigrants opportunities for civic engagement and possible employment opportunities. A small percentage of people in this sample have volunteered at local Latino organizations and expanded their network to volunteer in other community organizations, which in some cases opened up paid employment opportunities for these immigrants.

Consistent with Perreira, Chapman and Stein (2006), those who spend more time with American friends, coworkers, and with American family members tend to be more engaged than those who only spend time among members of the Mexican community. 
Barriers to Civic Engagement. For the most part Mexican immigrants have settled permanently in Oregon and only a very few consider going back to Mexico in a permanent way. The majority of Mexican immigrants appreciate living in Oregon and recognize that the Portland metropolitan area provides a nice and friendly environment in which to live and raise their children. However, Mexican immigrants face constraints to civic engagement in their communities of residence. The empirical evidence gathered through this study coincides with earlier findings on barriers to civic engagement found in the literature (Lopez \& Marcelo, 2008; Ramakrishnan \& Viramontes, 2006). The main obstacles found among the people interviewed for this research were lack of information, concern about getting into trouble with police, and fear of being deported. Even for those with permanent residency, a lack of knowledge of how to become a U.S. citizen or how to become involved with broader U.S. society prevails. Similarly, for those with undocumented status, the fear of deportation negatively influences their resettlement in Oregon.

Intrinsic barriers such as lack of transportation, lack of legal status, and limited ability to speak English also represent obstacles to Mexican immigrants' integration with the rest of society. Without strong English language skills, immigrants are not able to communicate or participate in building the social glue necessary for a cohesive society. Mastering the English language is the base of productive communication and integration of immigrants into the communities where they reside in the United States. English fluency not only allows migrants to create social ties with people from other cultural groups, but also facilitates better integration into the economic arena, which can be translated into economic gains for immigrants and their families. Language seems to be a 
significant barrier to civic engagement, which makes it an important issue to address among the adult Mexican immigrants living in Oregon. The research findings also point to lack of legal status and lack of transportation as compounding barriers to integration.

Mexican immigrants' past experiences with governments and nonprofit organizations affect the degree of engagement with these institutions. For many, negative experiences with these entities deter future engagement, but for others negative experiences are precisely what motivates them to get together and participate critically in important issues affecting their communities of origin or residence.

By the same token, pro-immigrant organizations and the Mexican consulate in Portland are examples of the formation of associations to protect immigrants' rights. However, findings suggest that in many cases, these organizations serve as a platform for cultural communication rather than a network that immigrants see as a potential place to seek out tangible help and become integrated. There is a general mistrust of these organizations and the Mexican Consulate among Mexican immigrants in Oregon. Although Mexican nationals see these organizations as forums to express Mexican culture, they do not view them as forums that necessarily represent the interests and the needs of the Mexican community that resides in Oregon. Often past oppression caused by the Mexican political system and social injustices experienced are not adressed when immigrants come to the United States. This sample shows that Mexican immigrants may bring the effects of oppresion and feelings of mistrust with them to their communities of residence, specifically in their relationship with the U.S. Federal government and its failure to pass comprehensive immigration reform as well as the increased frequency of recent deportations. 
Regardless of the previous barriers to civic engagement faced by the interviewees, for the most part, people from indigenous descent who have migrated to Oregon tend to have stronger connections with their communities of origin and in some cases have experience in political and cultural affairs in their communities of origin, an experience that can benefit their U.S. communities of residence.

\section{Policy Implications}

For most immigrants, international migration entails a huge environmental and cultural change and many lack an understanding of how things work in their new communities of residence in the United States. This study reinforces the need for the implementation of more inclusive policies that can facilitate the civic engagement of immigrants in the United States. As newcomers, people need help to adjust and learn how to become receptive and engaged with their local community. In order for Mexican immigrants to fully contribute to American society and economy, they need to understand the avenues for engagement in their communities of residence as well as obtain the right to legality. Without an understanding and appreciation of their commuities of residence and without legality, immigrants face undeniable barriers to their engagement.

Study respondents, especially those who have held leadership positions, repeatedly highlighted the need to educate the Mexican immigrant community on issues related to U.S. history and current U.S. affairs. This education could facilitate a greated appreciation by immigrants for the opportunities provided by lving in the United States. The goal of this education would be engagement with policy makers and researchers in the United States. This type of education and gratitude is also 
mentioned by Renshon (2007) when he says that "emotional attachment and identification are the mechanisms that underlie sacrifice, empathy, and service." The degree of emotional attachment that immigrants feel toward their new country is hardly mentioned and never measured. Instead, we rely on surrogate measures like self-reports on English language faculty (which focus on speaking, not reading or writing), education, or home ownership. Caution is merited on all these substitute measures since few like to publicly admit their language limitations, education is not synonymous with national attachment as even a casual perusal of informed punditry will reveal, and owning a house is not the same as loving your country (Renshon, 2007). Many immigrants lack the understanding of how the United States government and public organizations work. This lack of understanding may not just relate to immigrants, but also to U.S. citizens in general (Renshon, 2007).

Addressing this could take the form of creating programs to disseminate information regarding programs and services for newcomers as well as including information regarding naturalization eligibility and the application processes. Additionally, efforts should target reducing the obstables immigrants face in seeking naturalization and understanding their new communities of residence, such as the high cost and the length of the process as well as increase the opportunities for English language learning and providing classes related to American civics. This study suggests that policies aimed at increasing immigrant engagement can target schools, community organizations, and churches, which have the potential to increase their civic engagement. These efforts can include civic and language lessons as well as cultural 
celebrations where Mexican immigrants and members of the broader society can interact. Such services could provide the link between the need to integrate immigrants and their desire to learn more about Oregon, a desire that was expressed by the Mexican immigrants I interviewed.

Because of the trust and accountability issues towards nonprofit organizations highlighted in this research, just like U.S. citizens want to have their elected officials held accountable, pro-immigrant organizations that receive public funding should have the same accountability and public institutions should make them accountable to serving the needs of the communities they claim to represent.

Although, local government agencies have taken certain steps to promote the participation of Latino immigrant communities, such as having information about an event being covered in non-mainstream media such as "The Hispanic News," "El Latino de Hoy," or similar media outlets, the outreach/engagement usually stops there. Immigrants generally find this type of outreach inefficient and insufficient because they feel that their voice is not important and that their contribution for policy-making is not needed. One of the interviewees, a former school board member, shared her experiences dealing with Hispanic parents in an elementary school in Gresham, Oregon. In order to encourage parents to come to events, they sent personalized letters including their names, so "they felt that they were important, we invited them formally". This seems to be a great technique that could work for some public events.

Sometimes community residents who assist in open houses or public hearings do not know much about the issues that are discussed there. The way that information is shared and presented is crucial for their understanding and engagement with the material. 
Some people, both immigrants and U.S. citizens, who attended these public engagement forums felt that they were simply meetings giving out facts and data rather than public officials asking for people's opinions. This meeting format leads to disinterest in continued participation in such forums. People need to feel that their involvement is appreciated and that they can contribute to the well-being of their community. Similarly, besides the translation of dense English text-based materials, the use of visuals with appropriate and plain language will help immigrants to understand messages, especially for those who have low literacy levels even in the Spanish language (NW Oregon, 2007).

\section{Limitations to the Research}

There are some limitations to this study that could be addressed by future investigations. First, around 420,000 people of Mexican origin reside in the state. Fifty interviews were conducted as it was felt that the results reached saturation at this point and sufficient common themes had evolved. Despite this, it is possible that the results reflect only the feelings of the respondents of this particular sample. Many of the recommendations listed above can be incorporated to encourage the participation of thousands of Mexicans in Oregon to participate in future research.

There is an overrepresentation of the level of educational attainment in this sample. Most of the Mexican population in Oregon has low educational attainment, and this study captures a considerable number of people with higher educational attainment and in some cases college degrees as well as people with business and professional jobs. In 2012, I interviewed Mexicans with low levels of schooling who were working in the service industry and agriculture industry in the cities of Beaverton and Woodburn, Oregon. This dissertation provided an opportunity to expand the 2012 study to include a 
more varied sample that included professionals and small business owners to hear more points of view in order to issue general recommendations. This past research found that the majority of the population with generally low incomes and low educational attainment lack information on how to participate and/or spend more time with the American population.

Finally, conducting a mixed methods research with only 50 interviews was challenging because larger samples could have yielded more significant and better results (Morgan, 2013; Creswell, Plano Clark, \& Gutmann, et al., 2003). However, I was interested in the personal experiences of the interviewees, so in the development of the dissertation I placed greater emphasis on the qualitative part of the research that explored the elements impacting the Mexican community's integration into American society.

\section{Future Research}

Advances in technology and communication have enabled more immigrants to maintain ties with their families and communities of origin in Mexico (Portes et al., 1999; Preston, Kobayashi \& Man, 2006). This research suggests that Mexican immigrants use social media to communicate with friends and family, and local governments and organizations can promote civic engagement through social media. Future studies need to explore the manner in which Mexican immigrants use social media to become engaged in Mexican and American civic affairs.

Research suggests that transnationalism is carried out by only a minority of Mexican migrants living in the United States (Itzigsohn \& Giorguli-Saucedo, 2005; Portes, 2003). As Paasche and Fangen (2012) argue for future studies, transnationalism should not only focus on the different types of operations or modes of civic engagement 
performed by those residing abroad, but also on the frequency of those transactions to measure the impact of this practice.

Likewise, researchers should be aware that some Mexican migrant communities that have been studied often feel that academics have used them to get published, for the success of their careers. Researchers should focus on studies that Mexicans feel are important for their communities such as ways to promote health, educational opportunities for their children, and services they can access in Mexico while living in the United States, such as buying a house or getting health care in case they visit Mexico.

Researchers should explore research techniques in which not only the migrant information is obtained, but also where they are actively involved and feel that the research will benefit their community. In short, the Mexican migrants in this study argued for, without knowing the concept explicitly, participatory action research.

\section{Conclusion}

Mexicans tend to be organized to economically and socially help to develop their communities of origin while keeping the rights of belonging (DeSipio, 2011; EscamillaHamm, 2009; Fox, 2010; Rivera-Salgado, Gaspar-Bada \& Escala-Rabadan, 2005). At the same time, in the United States, many Mexicans actively participate in neighborhood associations, join organizations, attend churches, or volunteer at their children's school, etc. (Bada, Fox \& Selee, 2006).

The extent to which Mexican immigrants are able to integrate and participate in American society has interesting implications for both the United States and Mexico. Data from the interviews indicate that immigrants are willing to be integrated and many offer their time, skills, and money to nonprofit organizations in their communities of 
residence, particularly to religious organizations, schools, and nonprofit organizations such PCUN, CAUSA, Adelante Mujeres, community radios, etc.

A number of factors appear to influence the decision of Mexican immigrants to engage in Oregon. Overall, the level of civic engagement among people who have been in the United States longer is much higher than those who have arrived more recently, who may be working on securing their immediate basic needs.

Similarly, age is a clear factor influencing civic engagement. Older Mexicans are much more likely to volunteer, donate, and follow the news and current daily affairs. Mexican immigrants' education, occupation, and personal income are all linked to their civic participation. Those with higher educational attainment and those with higher personal incomes are also more likely to be involved with community organizations in Oregon. On the other hand, people from rural communities and an indigenous background, regardless of their personal income, are more willing to be involved with the well-being of their communities of origin, especially contributing economically to support their religious festivities. Interviewees stated their willingness to help and extend direct personal assistance to relatives and friends living in Mexico

In general, Mexicans living in the Portland and Salem metropolitan areas may have higher rates of volunteering and participating compared to those living in rural areas of the state. This is due to the fact that perceptions of immigrants in those regions are different from those in the metropolitan areas where people are more receptive to living with people from different backgrounds (Bada, Fox, Donnelly \& Selee, 2010).

The social and economic contributions of Mexican immigrants to the well-being of Oregonian communities is undoubtedly significant. They volunteer in schools, 
organizations, and are active members of religious groups. Mexican immigrants also hold positions of power as leaders in different organizations and, more recently, are becoming public servants or volunteering for political parties. Nevertheless, much work remains to achieve social inclusion. While federal efforts and resources, or the lack of them, provide a critical context for immigrant integration, the primary burden rests on local organizations, i.e. nonprofit organizations, pro-immigrant organizations, schools, churches, and local governments, to act as key links to Oregon communities and ultimately to achieve a more inclusive society.

Migration has been measured in economic terms and questions have evolved such as: do migrants contribute to that state more than the expenses that they generate? How much do they make? How much do they spend in the United States and how much do they send to their countries of origin? etc. However, little has been said about the emotional attachment of migrants to their communities of residence (Renshon, 2007). I have found through my studies that Mexican immigrants residing in the metropolitan areas of Portland and Salem are grateful to the U.S., and have a love not only for the natural beauty of the state, but also are appreciative of the people of Anglo-Saxon origin that according to their own words are "very friendly and although they do not understand your English, they are not bothered by it.” However, while study participants feel positively about being in Oregon, many still lack an understanding about many things in their communities of residence, including how they can become civically engaged (Renshon, 2007).

For the most part, transnational ties with family and friends in Mexico have not negatively influenced the desire of immigrants to participate and/or contribute to 
American society. However, other researchers suggest that these transnational ties "have expanded their sense of family and cultural identity" (Preston, Kobayashi \& Man, 2006). Mostly these people are immigrants who have settled permanently in the state and who feel a sense of belonging and appreciation for Oregon.

Demographic transitions in the United States point to a future where more opportunities will become available to influence and strengthen the civic power of Mexican immigrants and their descendants in the United States. The experiences collected here may not be representative of the entire population of Spanish-speaking migrants residing in Oregon. Nevertheless, the results offer significant insight into the civic engagement experiences of Mexican immigrants residing in Oregon, a population that has settled permanently in the state and will continue growing and shaping Oregon in the future. In conclusion, today the U.S. is a different society from the one that Tocqueville witnessed in the 1800 's. There is a critical need for different and innovative initiatives to civically engage citizens and new residents. 


\section{References}

Abu-Laban, Y., \& Garber, J. A. (2005). The Construction of the geography of immigration as a policy problem The United States and Canada compared. Urban Affairs Review, 40(4), 520-561.

Ainslie, R. C. (2014). Cultural mourning, immigration, and engagement: Vignettes from the Mexican experience. The New Immigrant in American Society: Interdisciplinary Perspectives on the New Immigration, 355.

Alba, R., Nee, V. (1997). Rethinking assimilation theory for a new era of immigration. International Migration Review.

Alvarado Juárez, A. M. (2008). Migración y pobreza en Oaxaca. El cotidiano, 23(148), 85-94.

Alcalá Tobón, C. (2013). La Migración a Estados Unidos en la comunidad de Molcaxac, Puebla. (Tesis para obtener el grado de Licenciado en Sociología). Benemérita Universidad Autónoma de Puebla, Puebla, Pue.

American Community Survey 2005-2009 Estimates. Retrieved from http://factfinder.census.gov/servlet/DatasetMainPageServlet?_program=ACS\&_s ubmenuId=datasets_2\&_lang=en

Aquino Moreschi, A. (2012). De las luchas indias al sueño americano. Experiencias migratorias de jóvenes zapotecos y tojolabales en Estados Unidos. Publicaciones de la Casa Chata.

Archibold, R. C., (2010). Arizona enacts stringent law on immigration. New York Times. Retrieved from http://www.nytimes.com/2010/04/24/us/politics/24immig.html

Attride-Stirling, J. (2001). Thematic networks: an analytic tool for qualitative research. Qualitative research, 1(3), 385-405.

Bacon, D. (2008). Illegal people. Boston, MA: Beacon Press.

Bada, X., Fox J., Selee A. \& Sánchez Álvarez, M. (2006). Al fin visibles: la presencia cívica de los migrantes mexicanos en los Estados Unidos. Woodrow Wilson International Center.

Bada, X., Fox, J. A., Donnelly, R., \& Selee, A. D. (2010). Context matters: Latino immigrant civic engagement in nine U.S. cities, reports on Latino immigrant civic engagement. Center for Global, International and Regional Studies.

Bada, X., Chacón, O. A. and Fox, J. (2010). Latino immigrants in the Windy City: New Trends in Civic Engagement. Woodrow Wilson International Center for Scholars. Retrieved from http://www.wilsoncenter.org/sites/default/files/Chicago\%20Eng.pdf

Barnes, W., \& Mann, B. C. (2011). Making local democracy work: Municipal officials' views about public engagement. National Civic Review, 100(3), 58-62.

Barreto, M., Fraga L. R., Manzano, S., Martinez-Ebers, V., and Segura, G. M. (2008). "Should They Dance with the One Who Brung 'Em?" Latinos and the 2008 Presidential Election. PSOnline. Retrieved from http://journals.cambridge.org.proxy.lib.pdx.edu/download.php?file=\%2FPSC\%2F PSC41_04\%2FS1049096508080967a.pdf\&code=3ed2644e6c88df46454f2789ffa $4 \mathrm{ab} 4 \mathrm{~d}$ 
Becerra, D., Androff, D. K., Ayon, C., \& Castillo, J. T. (2012). Fear vs. facts: Examining the economic impact of undocumented immigrants in the U.S.. J. Soc. \& Soc. Welfare 39, 111.

Black, J. H. (1987). The practice of politics in two dettings: Political transferability among recent immigrants to Canada. Canadian Journal of Political Science, 20(4), 731-753.

Bloemraad, I, Voss, K., Lee, T. (2011). The immigration rallies of 2006: What were they, how do we understand them, where do we go? In Voss, K. \& Bloemraad, I. (Eds.), Rallying for immigrant rights, Berkeley, CA: University of California Press.

Boccagni, P. (2012). Even a transnational social field must have its boundaries: Methodological options, potentials and dilemmas for researching transnationalism. Handbook of research methods in migration, 295.

Bryman, A. (2006). Integrating quantitative and qualitative research: how is it done?. Qualitative research, 6(1), 97-113.

Brown \& López. (2013). Mapping the Latino population, By State, County and City. Pew Research. Retrieved from http:/www.pewhispanic.org/2013/08/29/mapping-thelatino-population-by-state-county-and-city/

Bryman, A. (2012). Social research methods. Oxford University Press.

Bussel, R. (2008). Understanding the immigrant experience in Oregon: Research, analysis and recommendations from University of Oregon Scholars. Eugene, OR: University of Oregon.

Canales Cerón, Alejandro I. (2008). Remesas y desarrollo en América Latina: Una relación en busca de teoría. Migración y desarrollo, (11), 5-30.

Canedo Vásquez, G. (2008). Una conquista indígena. Reconocimiento de municipios por "usos y costumbres" en Oaxaca (México). In Cimadamore, A. (Ed.), La economía política de la pobreza. Buenos Aires: CLACSO. Retrieved from http://bibliotecavirtual.clacso.org.ar/ar/libros/clacso/crop/cimada/Vasquez.pdf

Card, D., \& Lewis, E. G. (2005). The diffusion of Mexican immigrants during the 1990s: Explanations and Impacts. NBER Working Paper No. 11552. National Bureau of Economic Research. Retrieved from http://www.nber.org/papers/w11552

Carlsen, L. (1999). Autonomía indígena y usos y costumbres: la innovación de la tradición. Revista Chiapas, 7, 2-17.

Carreón, G. P., Drake, C., \& Barton, A. C. (2005). The importance of presence: Immigrant parents' school engagement experiences. American Educational Research Journal, 42(3), 465-498.

CAUSA. (n.d.) Oregon's Immigrant Rights Organization. Retrieved from http://causaoregon.org/

CAUSA. (2012). Latino contributions to Oregon, strengthening our state economy. Oregon's Immigrant Rights Organization. Retrieved from http://causaoregon.org/wp-content/uploads/2012/05/Latino-Contributions-toOregon-Strengthening-Our-State-Economy.pdf

CESOP. (2004). El impacto de las remesas familiares en México y su uso productivo. Retrieved from http://www.diputados.gob.mx/cesop

Chacón, O. A. (2010). National alliance of Latin American and Caribbean communities. In Bada, X., Chacon, O. A. \& Fox, J. (Eds.), The windy city: New Trends in civic 
engagement, reports on Latino immigrant civic engagement. Washington, D.C.:

Woodrow Wilson International Center for Scholars. Retrieved from http://www.wilsoncenter.org/sites/default/files/Chicago\%20Eng.pdf

Chui, T. W., Curtis, J. E., \& Lambert, R. D. (1991). Immigrant background and political participation: examining generational patterns. Canadian Journal of Sociology/Cahiers canadiens de sociologie, 375-396.

Clark, V. L. P., \& Creswell, J. W. (2011). Designing and conducting mixed methods research.

Comisión Intersecretarial para la Transparencia. (2008). Participación ciudadana... ¿para qué? Hacia una política de participación ciudadana en el gobierno federal. Comisión Intersecretarial para la Transparencia. Retrieved from http://www.oic.sep.gob.mx/portal3/doc/Participacion\%20ciudadana.pdf

Consejo Nacional de Población. (2010). Índices de intensidad migratoria México-Estados Unidos. Conapo. Retrieved from http://www.conapo.gob.mx/work/models/CONAPO/intensidad_migratoria/pdf/Ef ectos.pdf

Corbett, J. G. (1979). Mexico-United States and West European labor migration: a comparative analysis. Praeger Special Studies, 223-244.

Corchado, A. (2012). Registration of Mexican voters living abroad lags. dallasnews. Retrieved from http://www.dallasnews.com/news/local-news/20120112registration-of-mexican-voters-living-abroad-lags.ece?nclick_check=1

Couton, P., \& Gaudet, S. (2008). Rethinking social participation: The case of immigrants in Canada. Journal of International Migration and Integration/Revue de l'integration et de la migration internationale, 9(1), 21-44.

Creswell, J. W. (2014). Research design: Qualitative, quantitative, and mixed methods approaches ( $4^{\text {th }}$ ed.). Thousand Oaks, CA: Sage Publications.

Creswell, J. W., Plano Clark, V. L., Gutmann, M. L., \& Hanson, W. E. (2003). Advanced mixed methods research designs. Handbook of mixed methods in social and behavioral research, 209-240.

Creswell, H.A., \& Plano Clark, V. (2011). Designing and conducting mixed methods research. ( $2^{\text {nd }}$ ed.). Thousand Oaks, CA: Sage Publications.

Crosnoe, R. (2006). Mexican roots, American schools. Helping Mexican immigrant children succeed. Palo Alto, CA: Stanford University Press.

Curiel, S. (2007). Strengthening Oregon's communities: Latino community leadership training (Thesis). Oregon State University. Retrieved from http://ruralstudies.oregonstate.edu/sites/default/files/pub/pdf/mppessay_curiel.pdf

D’Aubeterre Buznego, M. E. \& Rivermar Pérez, M. L. (2007). Tres circuitos migratorios Puebla-Estados Unidos: una lectura comparativa. Nuevo Mundo, Mundos Nuevos. Retrieved from http://nuevomundo.revues.org/10413?lang=en\#bibliography

DeSipio, L. (2011). Immigrant Incorporation in an era of weak civic institutions: Immigrant civic and political participation in the United States. American Behavioral Scientist, 55(9):1189-1213.

De Graauw, Els. (2013). Immigrants and political incorporation in the United States. Pp. 1875-1892 in Volume 4 of Immigrants in American History: Arrival, Adaptation, and Integration. Elliott Robert Barkan, editor. Santa Barbara: ABC-CLIO Books. 
De Tocqueville. A. (1835), Democracy in America Vol. I (translated by George Lawrence; edited by J.P. Mayer) London: Fontana Press.

Dreamstime (2015). Oregon map. Dreamstime. Retrieved from http://www.dreamstime.com/stock-images-oregon-map-image9637014

Dekker, P., \& Halman, L. (2003). The values of volunteering: Cross-cultural perspectives. Springer Science \& Business Media.

Denzin, N.K. (1978). The research act: A theoretical introduction to sociological methods. New York: McGraw-Hill.

Dudley, R. L., \& Gitelson, A. R. (2002). Political literacy, civic education, and civic engagement: A return to political socialization? Applied Developmental Science, 6(4), 175-182.

Durand, J. (2007). El Programa Bracero (1942-1964). Un balance crítico. Durand, J. (2007). El Programa Bracero (1942-1964). Un Balance Crítico. Red Internacional de Migración y Desarrollo, 27-43.

Durand, J. \& Massey, D. (2003). Clandestinos migración México-Estados Unidos en los albores del siglo XXI. Colección América Latina y el Nuevo Orden Mundial. México: Miguel Ángel Porrúa.

Durand, J., Massey, D. S., \& Capoferro, C. (2005). The new geography of Mexican immigration. In Zúñiga, V., \& Hernández-León, R. (Eds.), New Destinations, Mexican immigration in the United States. New York: Russell Sage Foundation, pp. 1-20.

Erisman, W., \& Looney, S. (2007). Opening the door to the American dream. Washington, D.C.: Institute for Higher Education Policy.

Escamilla-Hamm, P. (2009). How Transnationalism facilitates the participation of Mexican immigrants in U.S. politics. Migracion y Desarrollo. First Semester: 87110.

Escobar, C. (2007). Extraterritorial political rights and dual citizenship in Latin America. Latin American Research Review, 42(3), 43-75.

Feilzer, M. Y. (2010). Doing mixed methods research pragmatically: Implications for the rediscovery of pragmatism as a research paradigm. Journal of mixed methods research, 4(1), 6-16.

Félix, A., González, C., \& Ramírez, R. (2008). Political protest, ethnic media, and Latino naturalization. American Behavioral Scientist, 52(4), 618-634.

Fernández de Castro, R., Zamora, R. G., \& Freyer, A. V. (2006). El Programa 3x1 para migrantes: Primera política transnacional en México. Miguel Ángel

Porrúa/Instituto Tecnológico Autónomo de México/Universidad Autónoma de Zacatecas.

Fox, J. (2005). Mexican migrant civic and political participation. University of California Woodrow Wilson International Center for Scholars. Retrieved from

http://www.wilsoncenter.org/sites/default/files/Fox\%20-

\%20Mapping\%20Mex\%20Migrant\%20Civil\%20Society.pdf

Fox, J. (2006). Reframing Mexican migration as a multi-ethnic process. Latino Studies, 4(1), 39-61. 
Fox, J. (2010). Understanding Latino immigrant civic engagement: Context matters. In Context Matters: Latino immigrant civic engagement in nine U.S. cities. Woodrow Wilson International Center for Scholars.

Fox, J. \& Bada, X. (2008). Migrant organization and home-town impacts in rural Mexico. Journal of Agrarian Change, 8(2 and 3), 435-61.

Fox, J. \& Bada, X. (2011). Migrant civic engagement. In Voss, K. \& Bloemraad, I. (Eds.), Rallying for Immigrant Rights, Berkeley, CA: University of California Press.

Gandara, P., and Contreras, F. (2009). The Latino education crisis: The consequences of failed social policies. Cambridge, MA: Harvard University Press.

Garabito Elías, R. A. \& Torres Baños, R. E. (2004). Migración e impacto de las remesas en la economía nacional. Análisis económico, 19(41), 243-275.

García, J. (2003). Latino politics in America. New York, NY: Rowman \& Littlefield.

García, J. (2016). Latinos in Oregon. The Oregon Encyclopedia. Retrieved from http://oregonencyclopedia.org/articles/hispanics_in_oregon/\#.VqkRqugrJD8

García, R. (2011). Los aspirantes presidenciales buscan el voto de los mexicanos en EU. CNN Mexico. Retrieved from http://mexico.cnn.com/nacional/2011/06/15/losaspirantes-presidenciales-buscan-el-voto-de-los-mexicanos-en-eu

García, M. (2013). Illinois illegal immigrant driver's licenses available in 10 months. Chicago Tribune. Retrieved from http://articles.chicagotribune.com/2013-0127/news/ct-met-quinn-immigrant-drivers-licenses-0128-20130129_1_licensesillinois-illegal-immigrant-consular-identification-card

García, R. (2011). Los aspirantes presidenciales buscan el voto de los mexicanos en EU. CNN Mexico. Retrieved from http://mexico.cnn.com/nacional/2011/06/15/losaspirantes-presidenciales-buscan-el-voto-de-los-mexicanos-en-eu

García Zamora, R. (2007). El Programa tres por uno de remesas colectivas en México: Lecciones y desafíos. Migraciones Internacionales, 4(1), 165-172.

García Zamora, R. \& Orozco

M. (2009). Migración internacional, remesas y desarrollo local en América Latina y el Caribe; Colección Desarrollo y Migración. México: Miguel Ángel Porrúa, Universidad Autónoma de Zacatecas; Inter-American Dialogue.

Gamboa, E. (1990). Mexican labor and World War II: Braceros in the Pacific Northwest, 1942-1947. Austin: University of Texas Press.

Gamboa, E. \& Buan, C. (1995). Nosotros: the Hispanic people of Oregon: Essays and recollections. Portland, OR: Oregon Council for the Humanities.

Gibson, C. M. (2006). Citizens at the center, A new approach to civic engagement. The Case Foundation. Retrieved from http://casefoundation.org/sites/default/files/citizens-at-the-center.pdf

Gioioso, R. N. (2010). Placing immigrant incorporation: Identity, trust, and civic engagement in Little Havana. (Doctoral dissertation). Retrieved from ProQuest Dissertations and Thesis. UMI Number 3431297

Glick Schiller, N. (2003) The centrality of ethnography in the study of transnational migration: Seeing the wetlands instead of the swamp. In Foner, N. (ed.) American Arrivals, Santa Fe, School of American Research Press, pp. 99-128. 
Gonzales-Barrera, A. \& Lopez, M. H. (2013). A demographic portrait of Mexican-origin Hipanics in the United States. Pew Research Center. Retrieved from http://www.pewhispanic.org/2013/05/01/a-demographic-portrait-of-mexicanorigin-hispanics-in-the-united-states/

Gonzales, R. G., \& Chavez, L. R. (2012). Awakening to a nightmare. Current Anthropology, 53(3), 255-281.

Gonzales-Berry, E. \& Mendoza, M. (2010). Mexicanos in Oregon, their stories, their lives. Corvallis: Oregon State University Press.

Graves, B. (2011). Oregon Senate passes Bill to lower tuition for undocumented students. Oregon Live. Retrieved from http://www.oregonlive.com/education/index.ssf/2011/03/oregon_senate_passes_b ill_to_l.html

Guarnizo, L. E. (1998). The rise of transnational social formations: Mexican and Dominican State responses to transnational migration. Political Power and Social Theory, 12, 45-94.

Guarnizo, L. E., Portes, A., \& Haller, W. (2003). Assimilation and transnationalism: Determinants of transnational political action among contemporary migrants. American Journal of Sociology, 108(6), 1211-1248.

Gutierrez, J. J. (2012). What's wrong with Mexico's 2012 Presidential wlection? Gpnews.com. Retrieved from http://egpnews.com/2012/01/what $\%$ E2\%80\%99swrong-with-mexico\%E2\%80\%99s-2012-presidential-election/

Gutierrez, P. (1997). Mexico's dual nationality amendments: They do not undermine U.S. citizens' allegiance and loyalty or US political sovereignty. Loy. LA Int'l \& Comp. $L J, 19,999$.

Gutiérrez Flores, L. (2008). La distribución del ingreso en México: un análisis regional, 1990-2004. Problemas del Desarrollo. Revista Latinoamericana de Economía, 39(152), 139-163.

Hanson, G. (2006). Illegal migration from Mexico to the United States. Journal of Economic Literature. 44(4): 869-924.

Harper, R. A. (2007). An exploration of the role citizenship plays in the civic incorporation of permanent residents and naturalized citizens in New York and Berlin. Unpublished doctoral dissertation, The City University of New York

Harrits, G. S. (2011). More than method? A discussion of paradigm differences within mixed methods research. Journal of Mixed Methods Research, 1558689811402506.

Haubert, J., \& Fussell, E. (2006). Explaining pro-immigrant sentiment in the U.S.: Social class, cosmopolitanism, and perceptions of immigrants. International Migration Review, 40(3), 489-507.

Hernández, D. (1999). La construcción de gobernabilidad desde el ámbito municipal en México. Perfiles latinoamericanos: revista de la Facultad Latinoamericana de Ciencias Sociales, Sede México, (14), 83-102.

Hing, B. O. (2004). Defining America: Through immigration policy. Temple University Press.

Huntington, S. P. (2004). The Hispanic challenge. Foreign policy, 141(2), 30-45. 
Hurtado, J. \& Shoichet, C. E. (2013). New California law gives undocumented immigrants driver's licenses. CNN. Retrieved from

http://www.cnn.com/2013/10/03/us/california-undocumented-immigrant-driverslicenses/index.html

Hamm, P. H. E. (2009). How transnationalism facilitates the participation of Mexican immigrants in American politics. Unpublished paper, El Colegio de la Frontera Norte, Tijuana, Dept. Studies of Public Administration. Retrieved from http://www. Huellasmexicanas.com/alejandra/migracion-y-politica/How\% 20Transnationalism\% 20Facilitates\% 20Particip\% 20of\% 20Mex \% 20Immigr\% 20in\% 20US\% 20Politics

Hondagneu-Sotelo, P. (1994). Gendered transitions: Mexican experiences of immigration. University of California Press.

Hritzuk, N., \& Park, D. K. (2000). The Question of Latino participation: From an SES to a social structural explanation. Social Science Quarterly, 151-166.

Hurtado, J.\& Shoichet, C. E. (2013). New California law gives undocumented immigrants driver's licenses. CNN. Retrieved from http://www.cnn.com/2013/10/03/us/california-undocumented-immigrant-driverslicenses/index.html

ILG. (2012). Ten ideas to encourage immigrant engagement. Institute for Local Government. Retrieved from http://www.ca-ilg.org/sites/main/files/fileattachments/ten_ideas_to_encourage_immigrant_engagement-jan_2012_0.pdf

INE (n.d.). Electoral registry. Instituto Nacional Electoral. Retrieved from http://www2.ine.mx/archivos3/portal/historico/contenido/Electoral_Registry/

Itzigsohn, J., \& Giorguli-Saucedo, S. (2005). Incorporation, transnationalism, and gender: Immigrant incorporation and transnational participation as gendered processes. International Migration Review, 895-920.

Itzigsohn, J., \& Giorguli-Saucedo, S. (2002). Immigrant incorporation and sociocultural transnationalism. International Migration Review, 766-798.

Ivankova, N. V., Creswell, J. W., \& Stick, S. L. (2006). Using mixed-methods sequential explanatory design: From theory to practice. Field Methods, 18(1), 3-20.

Jáuregui Casanueva, L. (2008). The Impact of the social investment of collective remittances on the relationship between public and private: The Case of the" Tres Por Uno para migrantes". Journal of Latino/Latin American Studies, 3(1), 40-55.

Jick, T.D. (1983). Mixing qualitative and quantitative methods: Triangulation in action. In J. Van Maanen (Ed.), Qualitative methods. Beverly Hills: Sage

Jones, M.J. (2013). Most in U.S. say it's essential that immigrants learn English. GALLUP. Retrieved from http://www.gallup.com/poll/163895/say-essentialimmigrants-learn-english.aspx

Jones, R. (2013). Oregon legislators pass bill granting driving rights to the undocumented. El Hispanic News. Retrieved from http://www.elhispanicnews.com/2013/05/02/oregon-legislators-pass-bill-grantingdriving-rights-to-the-undocumented/

Johnson, S. (1999). Applying social capital theory to needs assessment, social program development, and evaluation: A practitioner's perspective. Administrative Theory \& Praxis, 12-22. 
Johnson, R. B., \& Onwuegbuzie, A. J. (2004). Mixed methods research: A research paradigm whose time has come. Educational researcher, 33(7), 14-26.

Juárez Martínez, M.L. et al. (2002). Políticas de salud, migración internacional e impactos en la salud en Zacatecas, Unidad Académica de Enfermería, UAZ.

Keeter, S., Zukin, C. Andolina, M., \& Jenkins, K. (2002). The civic and political health of the nation: A generational portrait. College Park, MD: CIRCLE, The Center for Information and Research on Civic Learning and Engagement, University of Maryland.

King, M. C. \& Corbett, J. G. with Chiappetta J., Escribano, L., López Salinas, A. \& Sprague, W. W. Jr., (2011). Assessment of the socio-economic impacts of SB 1080 on immigrant groups. Oregon Department of Transportation. Final Report. SR 500-270. Retrieved from http://cms.oregon.gov/ODOT/TD/TP_RES/docs/Reports/2011/SB1080.pdf

Kissam, E. \& Stephen, L. (2006). The new pluralism in woodburn, oregon: A community study conducted in 2003-2004. Burlingame, CA: Aguirre Division, JBS International. Retrieved from wnw.uoregon.edu/pdf_imm/Short\%20WoodburnFinal\%209-15.pdf

Kochhar, R. (2005). Survey of Mexican migrants, part three. Pew Hispanic Center, Washington, DC. Retrieved from http://www.pewtrusts.org/uploadedfiles/wwwpewtrustsorg/Reports/Hispanics_in_ America/PHC_mexican_migrants_1205.pdf

Krathwohl, D. R. (2009). Methods of educational and social science research: The logic of methods. Waveland Press.

Labissiere, Y., Goraczko, A. R., \& Stepick, A. (2009). Religious practice and civic social capital among miami youth. Churches and charity in the immigrant city: Religion, immigration, and civic engagement in Miami, 231.

Ladd, E. C. (1999). The ladd report. New York: Free Press. Retrieved from http://www.nytimes.com/books/first/l/ladd-report.html

Lafleur, J. M., \& Chelius, L. C. (2011). Assessing emigrant participation in home country elections: The case of Mexico's 2006 Presidential election. International Migration, 49(3), 99-124.

Levitt, P. (2000). Migrants participate across borders: Towards an understanding of forms and consequences. In N. Foner, R. Rumbaut, and S. J. Gold (Eds.), Immigration Research for a New Century. New York: Russell Sage.

Levitt, P., \& Jaworsky, B. N. (2007). Transnational migration studies: Past developments and future trends. Annu. Rev. Sociol., 33, 129-156.

Levitt, P. \& Waters, M. C. (2002). Introduction. In Levitt, P. And Waters, M. C., The changing face of home: The transnational lives of the second generation. New York: Russell Sage.

Loges, W., Ball-Rokeach, S., \& Qiu, J. L. (2003, February 28-March 1). Broken bonds at work, broken bonds at home: A theoretical connection. Paper presented to the conference from 9-to-5 to 24/7: How Workplace Changes Impact Families, Work, and Communities, Orlando, Florida.

Lopez, G. (2001). The value of hard work: Lessons on parent involvement from an (im)migrant household. Harvard Educational Review, 71, 416-37. 
López, M. H., \& Marcelo, K. B. (2008). The civic engagement of immigrant youth: New evidence from the 2006 Civic and Political Health of the Nation Survey. Applied Development Science, 12(2), 66-73.

López, M. H. \& Taylor, P. (2009). Dissecting the 2008 electorate: Most diverse in U.S. history. Pew Research Hispanic Center. Retrieved from http://www.pewhispanic.org/2009/04/30/dissecting-the-2008-electorate-mostdiverse-in-us-history/

López, M. H. \& Taylor, P. (2012). Latino voters in the 2012 election. Pew Research Hispanic Center. Retrieved from http:/www.pewhispanic.org/2012/11/07/latinovoters-in-the-2012-election/

Lozano, F. (2003). Discurso oficial, remesas y desarrollo en México. Migración y Desarrollo, 1(1), 23-31.

Lozano Ascencio, F. (2004). Tendencias recientes de las remesas de los migrantes mexicanos en Estados Unidos. Center for Comparative Immigration Studies.

Luibheid, E. (2002). Entry denied, controlling sexuality and the border. University of Minnesota Press.

Madison, L. (2012). Romney on immigration: I'm for "self-deportation". CBS NEWS. Retrieved from http://www.cbsnews.com/news/romney-on-immigration-im-forself-deportation/

Markus, H. R., Steele, C. M., \& Steele, D. M. (2000). Colorblindness as a barrier to inclusion: Assimilation and nonimmigrant minorities. Daedalus, 233-259.

Martín R. (2012). Peña Nieto y Atenco. El Economista. Retrieved from http://eleconomista.com.mx/columnas/columna-especialpolitica/2012/05/21/pena-nieto-atenco

Martinez, L. M. (2011). Mobilizing marchers in the mile-high city: The role of the community- based organizations. In Voss K. And I. Bloemraad, Rallying for immigrants rights. the fight for inclusion in $21^{\text {st }}$ Century America, University of California Press

Martínez Nateras, N. \& Stanley, E. (2009). Participación cívica y política de los inmigrantes Latinos en Fresno y Madera, California". Reportes sobre la Participación Cívica Latina, Núm. 3. Washington, D.C.: Centro Internacional Woodrow Wilson para Académicos.

Martinez-Starke, A. (2011). Beaverton: Oregon's most diverse City. IIP Digital. Retrieved from Http://iipdigital.usembassy.gov/st/english/publication/2010/12/20101222111657y elhsa0.8702341.html\#axzz1jauowv6a

Martinson, M., \& Minkler, M. (2006). Civic engagement and older adults: A critical perspective. The Gerontologist, 46(3), 318-324.

Marrow, H. B. (2011). New destination dreaming: Immigration, race, and legal status in the rural American South. Stanford, CA: Stanford University Press

Massey, D. S. (2010). Assimilation in a new geography. In Douglass, M. (eds.), New faces in new places: the changing geography of American immigration. New York: Russell Sage Foundation. 
Massey, D. S., \& Higgins, M. E. (2011). The effect of immigration on religious belief and practice: A theologizing or alienating experience?. Social science research, 40(5), 1371-1389.

Massey, D. S., \& Parrado, E. (1994). Migradollars: The remittances and savings of mexican migrants to the USA. Population Research and Policy Review, 13(1), 330.

Massey, D. S. \& Sanchez M. R. (2010). Brokered boundaries, creating immigrant identity in anti-immigrant times. Russell Sage Foundation.

Massey, D. S., \& Sana, M. (2003). Patterns of U.S. migration from Mexico, the Caribbean, and Central America. Migraciones Internacionales. 2(2), 5-39.

Meléndez Yúdico, J.A. (2012). 10 puntos sobre el voto de los mexicanos en el exterior. Terra Nostra. Retrieved from http://www.animalpolitico.com/blogueros-terranostra/2012/08/02/10-puntos-sobre-el-voto-de-los-mexicanos-en-el-exterior/

Merino, M. (1995). En busca de la democracia municipal. La participación ciudadana en el gobierno local mexicano. El Colegio de México, México.

Milkman, R. (Ed.). (2000). Organizing immigrants: The challenge for unions in contemporary California. Cornell University Press.

Missioninsite. (2011). Study Area: zipcode 97005. Quickinsite Report.

Moctezuma Longoria, M. (2005). Morfología y desarrollo de las asociaciones de migrantes mexicanos en Estados Unidos. Un sujeto social y político extraterritorial. Migración y Desarrollo, 5, 59-85.

Moctezuma Longoria, M. (2011). Remesas familiares y colectivas e inversión social y empresarial de los migrantes. Retrieved from http://rimd.reduaz.mx/documentos_miembros/2Cap\%C3\%adtulo5.pdf

Molina-Azorín, J. F., López-Gamero, M. D., Pereira-Moliner, J., \& Pertusa-Ortega, E. M. (2012). Mixed methods studies in entrepreneurship research: Applications and contributions. Entrepreneurship \& Regional Development,24(5-6), 425-456.

Morgan, D. L. (1998). Practical strategies for combining qualitative and quantitative methods: Applications to health research. Qualitative health research, 8(3), 362376.

Mueller, D. C. (1976). Public Choice: A Survey. Journal of Economic Literature 14(2), 395-433.

Narro, V., Wong, K., and Shadduck-Hernández, J. (2007). The 2006 immigrant uprising: Origins and future. New Labor Forum, 16(1), 46-58.

Nevarez, G. (2015). Undocumoney campaign shows immigrants' economic contributions. NBC News. Retrieved from http://www.nbcnews.com/news/latino/undocumoney-campaign-sheds-lightimmigrants-economic-impact-n418991

Núñez, A. (2015). Immigrants bolster academic and civic engagement in the U.S. The New York Times. Retrieved from http://www.nytimes.com/roomfordebate/2015/09/03/is-immigration-really-aproblem-in-the-us/immigrants-bolster-academic-and-civic-engagement-in-the-us

Odgers, O., \& Touraine, A. (2001). Identités frontalières: immigrés mexicains aux EtatsUnis. l'Harmattan. 
Oregon Department of Education (2012). Statewide Report Card: An Annual Report to the Legislature on Oregon Public Schools, 2011-2012. Salem, OR: Oregon Department of Education. Retrieved from: http://www.ode.state.or.us/search/page/?id=1821.

Orozco, M. (2003). Remittances, the rural sector, and policy options in Latin America. In United States Agency for International Development-World Council of Credit Unions conference, "Paving the Way Forward for Rural Finance: An International Conference on Best Practices”, Washington, DC (pp. 2-4).

Orozco, M., \& Lapointe, M. (2004). Mexican hometown associations and development opportunities. Journal of International Affairs, 57(2), 31-52.

Ortiz Gabriel, M. 2012. Migración y políticas públicas en Oaxaca. Un acercamiento a la acción gubernamental. In A-J, A.M. (Eds.), Migración, Ciudadanía y Políticas Públicas en Oaxaca. Universidad Autónoma "Benito Juárez" de Oaxaca.

Østergaard-Nielsen, E.K. (2001). The Politics of migrants' transnational political practices. Retrieved from http://www.transcomm.ox.ac.uk/working\%20papers/WPTC-0122\%20Ostergaard.doc.pdf

Paasche, E., \& Fangen, K. (2012). Transnational involvement: reading quantitative studies in light of qualitative data. International Journal of Population Research, 2012.

Paredes, M. (2012). Incipiente participación ciudadana en México. Contralinea Periodismo de Investigación. Retrieved from http://contralinea.info/archivorevista/index.php/2012/09/13/incipiente-participacion-ciudadana-en-mexico/

Passel, J \& Cohn, D. (2011). Unauthorized immigrant population: national and state trends, 2010. Pew Research. Retrieved from http://www.pewhispanic.org/2011/02/01/unauthorized-immigrant-populationbrnational-and-state-trends-2010/

Perreira, K. M., Chapman, M. V., \& Stein, G. L. (2006). Becoming an American parent: Overcoming challenges and finding strength in a new immigrant Latino community. Journal of Family Issues, 27(10), 1383-1414.

Perlmann, J. (2005). Italians then, Mexicans now. immigrant origins and secondgeneration progress, 1890 to 2000. New York: Russell Sage Foundation.

Pew Hispanic Center. (2005). Report by Jeffrey S. Passel. Estimates of the size and characteristics of the undocumented population. Retrieved from http://www.pewhispanic.org/2005/03/21/estimates-of-the-size-and-characteristicsof-the-undocumented-population/

Pew Hispanic Center. (2016). Demographic profile of Hispanics in Oregon, 2011. Pew Research Center. Retrieved from http://www.pewhispanic.org/states/state/or/

Population Research Center. (2010). 2010 Census Profiles Oregon and its Counties and Metropolitan Areas. Population Research Center, Portland State University. Retrieved from http://www.pdx.edu/sites/www.pdx.edu.prc/files/media_assets/2010_PL94_count y_MSA_updated.pdf

Portes, A., \& DeWind, J. (2006). Repensando las migraciones. Nuevas perspectivas teóricas y empíricas. Porrúa, México. 
Portes, A. (1999). Conclusion: Towards a new world: The origins and effects of transnational activities. Ethnic and Racial Studies, 22(2), 463-477.

Portes, A. (2003). Conclusion: Theoretical convergences and empirical evidence in the study of immigrant transnationalism. International Migration Review, 37(3), 874892.

Portes, A., Guarnizo, L. E., \& Landolt, P. (1999). The study of transnationalism: Pitfalls and promise of an emergent research field. Ethnic and Racial Studies, 22(2), 217237.

Portes, A. \& Rumbaut, R. G. (2006). Immigrant America. A portrait. Berkeley: University of California Press.

Preston, V., Kobayashi, A., \& Man, G. (2006). Transnationalism, gender, and civic participation: Canadian case studies of Hong Kong immigrants. Environment and Planning A, 38(9), 1633.

Putnam, R. D. (2000). Bowling alone: The collapse and revival of American community. New York: Simon \& Schuster.

Ramakrishnan, S. K., \& Baldassare, M. (2004). The ties that bind: Changing demographics and civic engagement in California. San Francisco, CA: Public Policy Institute of California.

Ramakrishnan, S. K., \& Viramontes, C. (2006). Civic inequalities: immigrant volunteerism and community organizations in California. Public Policy Institute of California.

Renshon, S. A. (2007). Becoming American: The hidden core of the immigration debate. Center for Immigration Studies.

Reyes Morales, R. G., \& Cruz, A. S. G. (2007). Desarrollo rural, migración internacional y escasez de mercados financieros en México. Trace. Travaux et recherches dans les Amériques du Centre, (52), 45-62.

Reyes Morales, R. G. \& Gijón Cruz A. S. (2011). Bienestar y remesas internacionales de los hogares rurales de México. Memorias del IV Congreso de la Red Internacional de Migración y Desarrollo: Crisis global y estrategias migratorias. FLACSO - Quito, Ecuador.

Reyes Morales, R. G., Mata Sánchez, N. D., Gijón-Cruz, A. S. And López Platas, S. (2009). Impacto del turismo nostálgico y las remesas familiares en el desarrollo de comunidad rural oaxaqueña. Migración y desarrollo, 12.

Reyes Romo, F. (2007). Transnacionalismo y participación política. Consideraciones teórico-metodológicas para el desarrollo de un sistema electoral con participación extraterritorial. Congresistas, 149-153.

Richman, K. E. (2008). Call us vote people: Citizenship, migration and transnational politics in Haitian and Mexican locations. In D. Reed-Danahay and C. Brettell (Eds), Citizenship, political engagement, and belonging: Immigrants in Europe and the United States, Rutgers University Press.

Rivera-Salgado, G., Bada, X. \& Escala-Rabadan, L. (2005). Mexican migrant civic and political participation in the U.S.: The case of hometown associations in los Angeles and Chicago. Woodrow Wilson International Center for Scholars. Retrieved from 
Http://www.wilsoncenter.org/sites/default/files/Rivera\%20Bada\%20Escala\%20\%20Hometown\%20Assn\%20in\%20LA\%20\%26\%20Chicago\%20\%28Esp\%29.pd $\mathrm{f}$

Rivera-Salgado, G. (2006). Mexican migrants and their Mexican political system. In J. Fox, X. Bada, and A. Selee (Eds.), Invisible no more: Mexican migrant civic participation in the United States, 31-33. Washington, DC: Woodrow Wilson International Center for Scholars.

Rivera-Salgado, G. \& Wilson, V. (2009). Today we march, tomorrow we vote: Latino migrant engagement in L.A. Woodrow Wilson International Center for Scholars.

Rivera, Sánchez. L. (2011). Circuitos migratorios transnacionales entre Puebla y Nueva York: Una introducción In Ibarra, M. M., \& Rivera, S. L. (Eds.). Entre contextos locales y ciudades globales: La configuración de circuitos migratorios PueblaNueva York. Puebla, México: Universidad Iberoamericana Puebla.

Rodríguez, H., Sáenz, R., Rodríguez, C. E., Menjivar, C., \& Massey, D. S. (2007). Latinas/os in the United States: Changing the face of America. Springer Science \& Business Media.

Rosenfeld, R., Messner S.F., Baumer, E.P. (2001). Social capital and homicide. Soc. Forces, 80:283-309.

Rosenblum, M. R., Kandel, W. A., Seelke, C. R., \& Wasem, R. E. (2012). Mexican migration to the United States: Policy and trends. Congressional Research Service.

Rubenstein, H. (1992). Migration, development and remittances in rural Mexico. International migration, 30(2), 127-153.

Sanchez, G. J. (1997). Face the nation: Race, immigration, and the rise of nativism in late twentieth century America. International Migration Review, 31(4), 1009-1030.

Sánchez Díaz de Rivera, M. E. \& Hernández Rojas, L. (2012). Como las mariposas monarca. Migración, identidad y métodos biográficos. Colección Lupus Inquisitor

SEDESOL. (2010). Cuarto Informe Trimestral 2010.

SEDESOL. (2013). Programa 3xl para Migrantes. Retrieved from http://www.sedesol.gob.mx/es/SEDESOL/Programa_3x1_para_Migrantes

Schwandt, T. A. (1997). Qualitative inquiry: a dictionary of terms. Thousand Oaks, CA: Sage.

Scott, K., Selbee, K., \& Reed, P. B. (2006). Making connections: Social and civic engagement among Canadian immigrants. Kanata, ON: Canadian Council on Social Development.

Seif, H. (2010). The civic life of Latina/o immigrant youth: Challenging boundaries and creating safe spaces. Handbook of research on civic engagement in youth, 445470.

Smith, R. C. (2008). Contradictions of diasporic institutionalization in Mexican politics: the 2006 migrant vote and other forms of inclusion and control. Ethnic and Racial Studies, 31(4), 708-741.

Snel, E., Engbersen, G., \& Leerkes, A. (2006). transnational involvement and social integration. Global Networks, 6(3), 285-308. 
Stepick, A., Rey, T., \& Mahler, S. J. (2009). Religion, immigration and civic engagement. In Stepick, A., Rey, T., and Mahler, S. J (Eds.), Churches and charity in the immigrant city. Rutgers State University of New Jersey.

Stephen, L. (2007). Transborder Lives: Indigenous Oaxacans in Mexico, California, and Oregon. Duke University Press.

Stephen, L. \& Mendoza, M. (2008). Latinos in Oregon. In Overmeyer-Velazquez, M. Latino America: A State-by-State Encyclopedia, 2008.

Stephen, L., Mendoza M., \& Magaña M. (2008). Latin American immigration in rural Oregon. In R. Bussel, Understanding the immigrant experience in Oregon: Research.

Suarez-Orozco, C., \& Suárez-Orozco, M. M. (1995). Transformations: Immigration, Family Life, and Achievement Motivation among Latino Adolescents. Stanford University Press.

Sugrue, T. (1996). The origins of the urban crisis. Princeton, NJ: Princeton University Press.

The Oregon Community Foundation. (2011). Metropolitan Portland regional profile. The Oregon Community Foundation. Retrieved from

http://www.oregoncf.org/Templates/media/files/regional_profiles/metro_profile_2 011.pdf

Terrazas, A. (2010). Mexican immigrants in the United States. Migration Policy Institute. Retrieved from

http://www.migrationinformation.org/usfocus/display.cfm?ID=767\#11

Terriquez, V. (2011). Schools for democracy labor union participation and Latino immigrant parents' school-based civic engagement. American Sociological Review, 76(4), 581-601.

Tucker, C. M., \& Santiago, A. M. (2013). The role of acculturation in the civic engagement of Latino immigrants. Advances in Social Work, 14(1), 178-205.

Ulin, P.P., Robinson, E. T., \& Tolley, E. E., (2005). Qualitative methods in public health. A field guide for applied research. Jossey Bass.

U.S. Census Bureau. 1990-2010. Retrieved from http://www.census.gov/

Vanwey, L. K., Tucker, C. M., \& McConnell, (2005). Community organization, migration, and remittances in Oaxaca. Latin American Research Review, 40(1), 83-107

Velasco-Ortiz, L. (2005). Desde que tengo memoria. Narrativas de identidad en indígenas migrantes. El Colegio de la Frontera Norte. Fondo Nacional para la Cultura y las Artes.

Verba, S., Schlozman, K. L. \& Brady, H.E. (1995). Voice and equality: Civic voluntarism in American politics. Cambridge, MA: Harvard University Press.

Villagran, L. (2012). Few in U.S. register to vote for Mexico Presidential elections. Fox News Latino. Retrieved from http://atino.foxnews.com/latino/politics/2012/01/13/few-in-us-register-to-votefor-mexico-presidential-elections/

Villarreal, M. A. (2010, September). The Mexican economy after the global financial crisis. Library of Congress, Washington DC: Congressional Research Service. 
Viruell-Fuentes, E. A. (2006). "My Heart is Always There": The transnational practices of first-generation Mexican immigrant and second-generation Mexican American Women. Identities: Global studies in culture and power, 13(3), 335-362.

Voss, K. \& Bloemraad, Irene. (2011). Rallying for immigrants rights. The fight for inclusion in $21^{\text {st }}$ century America. University of California Press

Voto Extranjero. N.d. Instituto Federal Electoral. Retrieved from http://www.votoextranjero.mx/

Walsh, M. (2003). Teaching qualitative analysis using QSR NVivo. The Qualitative Report, 8(2), 251-256.

Warren, M. (2001). Dry bones rattling. Princeton, NJ, Princeton University Press.

Warren, R. (2009). Unauthorized residents in Oregon by national origin, 2007. Personal Communication.

Warren, L. (2012). Record number of Hispanic and Asian Vters head to the polls to help Obama secure second term - as his support among whites plummets. Mailonline. Retrieved from http://www.dailymail.co.uk/news/article-2229225/Presidentialelection-2012-Record-number-Hispanic-voters-head-polls.html

Waters, J. (2003). Flexible citizens? Transnationalism and citizenship amongst economic immigrants in Vancouver. The Canadian Geographer/Le Géographe Canadien, 47(3), 219-234.

Waters, M. C. (2007). Immigration, intermarriage, and the challenges of measuring racial/ethnic identities. In D. Grusky and S. Szonja, The Inequality Reader: Contemporary and Foundational Readings in Race, Class, and Gender. Westview Press.

Wilkin, H. A., Vikki, S., \& Sandra, J. (2009). The role of family interaction in new immigrant Latinos' civic engagement. Journal of Communication, 59(2), 387406.

Wise, R. D., \& Ramírez, H. R. (2001). The emergence of collective migrants and their role in Mexico's local and regional development. Canadian Journal of Development Studies/Revue canadienne d'études du développement, 22(3), 747764.

Wong, A. (2015). Why civics is about more than citizenship. The Atlantic. Retrieved from http://www.theatlantic.com/education/archive/2015/09/civic-educationcitizenship-test/405889/

Wong, M. (2003). Borders that separate, blood that binds: The transnational activities of Ghanaian women in Toronto. PhD Dissertation, Department of Geography, York University, Toronto.

Wuthnow, R. (1999). Mobilizing civic engagement: The changing impact of religious involvement. Civic engagement in American democracy, 331-363.

Zheng, Y. (2013). Gov. John Kitzhaber Signs Tuition Equity Bill. Oregonlive. Retrieved from

http://www.oregonlive.com/politics/index.ssf/2013/04/gov_john_kitzhaber_signs_ tuiti.html

Ziccardi, A. (2000). La participación ciudadana como componente de la gobernabilidad democrática: el caso del distrito federal. In B. \& M.A. (Eds.) El Siglo de la Revolución Mexicana, INEHRM, México. 
Appendix A. English and Spanish Study Flyers 


\section{Are you involved in your community?}

\section{Volunteers wanted for a research study on Mexican immigrants' civic engagement}

Anabel Lopez Salinas, a graduate student at the Hatfield School of Government at Portland State University will be conducting interviews to learn more about the paths and barriers to civic engagement among the Mexican immigrant community in Oregon.

The interviews will take approximately 60 minutes and conducted in Spanish. This interview is completely confidential. Participants will receive a $\$ 10$ gift card in appreciation of their time. 


\title{
¿Está involucrado en su comunidad?
}

\begin{abstract}
Se requiere de voluntarios que quieran ser entrevistados para estudio de investigación sobre participación cívica de migrantes Mexicanos en Oregon.
\end{abstract}

Anabel López Salinas, una estudiante de posgrado de la escuela de gobierno de la Universidad Estatal de Portland estará realizando entrevistas para aprender sobre las formas y barreras de participación cívica de la población migrante de origen mexicano que reside en Oregon.

Las entrevistas duraran aproximadamente 60 minutos y serán en el idioma español. Esta entrevista es completamente confidencial. Las personas que participen en la entrevista recibirán una tarjeta de regalo de $\$ 10$ en apreciación a su tiempo.

Si usted quiere participar, por favor contacte a Anabel López Salinas al teléfono 503-9518580 o al correo electrónico alopez2@pdx.edu. 
Appendix B. Cover Letter for Informed Consent 
$<$ Letterhead $>$

\section{Exploring Economic, Social, and Political Participation of Mexican Immigrants in Oregon}

My name is Anabel Lopez Salinas and I am a doctoral student at Portland State University. I am conducting a research project on "Exploring Economic, Social and Political Participation of Mexican Immigrants in Oregon". I would like to extend you an invitation to participate in the study as your inputs will contribute greatly to the research.

This research focuses on learning what civic engagement means to you both in your community of origin and in the community where you live currently. I would like to know more about the barriers and opportunities people encounter when participating in the American community and how your civic engagement here in the United States influences your community back home. The interview should not take more than 50 minutes.

I will be analyzing the responses in order to write my dissertation but also to increase awareness of ways to enhance communication between a growing Mexican immigrant population and interested public officials.

You may be worried that I might discuss something that you would not like to someone else - other than me -- to know, for any reason. Please be reassured that I will not talk with anyone about anything you tell me. I will keep my notes on this conversation in a locked file drawer, along with the recording. When I write anything to be published, I will not include any details that could identify you, such as your name, the name of your employer or any unusual family circumstances or personal characteristics.

Your participation in this project is completely voluntary, and will not affect your relationship with anyone else. You may stop this conversation at any point, if you wish to.

If you have concerns about your participation in this study, you may contact Portland State University about them. The people to talk to there are the Human Subjects Research Review Committee, Office of Research and Sponsored Projects, 600 Unitus Building, 503-725-2227, or toll-free, 1-877-480-4400.

If you have questions about the study itself, you can contact me at (503-9518580) or my supervisor directing this study, Jack Corbett at 503-725-8250. Please keep this letter, so that you've got our contact information.

Thank you for all your help!!!!!

Anabel Lopez Salinas 
$<$ Letterhead $>$

\section{Explorando la Participación Económica, Social y Política de la Población Mexicana Migrante en Oregon}

Mi nombre es Anabel Lopez Salinas; estudiante de posgrado en la Universidad Estatal de Portland (PSU). Estoy llevando a cabo un proyecto de investigación sobre la "Participación Cívica de la Población Mexicana Migrante en Oregon". Me gustaría pedirle su colaboración en este estudio, ya que su participación contribuiría grandemente a nuestra investigación.

Este proyecto se centra en saber cuáles son los medios de participación cívica con su comunidad de origen y en Oregon. Me gustaría saber cuáles son las barreras y oportunidades que le gente encuentra cuando participa cívicamente en las comunidades estadounidenses; y de qué manera esta participación influye en su comunidad de origen. La duración de la entrevista será de entre 30 a 50 minutos.

Analizaré las respuestas con el fin de escribir mi tesis de doctorado pero al mismo tiempo crearé reportes con el fin de incrementar el conocimiento de los servidores públicos interesados acerca de las necesidades de la creciente comunidad Latina.

Por favor tenga la seguridad de que la información que nos proporcione será completamente confidencial, no pediremos nombres ni dirección que pudieran identificarle. Mantendré mis notas en un lugar seguro para que no pueda usted ser identificado.

Su participación en este proyecto es completamente voluntaria y usted puede detener la conversación si en algún momento se siente incómodo.

Si tienes preguntas acerca de su participación en este estudio; puede contactar a la Universidad Estatal de Portland (Portland State University). La gente a la que debe dirigirse son the Human Subjects Research Review Committee, ubicados en Market Center Building, Sexto piso, 1600 SW 4th Ave, 503-725-2227 o llame sin costo al 1-877480-4400.

Si usted tiene preguntas sobre el estudio mismo puede contactarme al 503-951-8580 o puede contactar a mi profesor/supervisor: Jack Corbett al 503-725-8250. Por favor mantenga esta carta por si usted tiene preguntas y necesita contarnos en el futuro.

Gracias por todo su apoyo!!

Anabel Lopez Salinas 
Appendix C. Interview Guide for a Semi-Structured Interview 


\section{Exploring Economic, Social, and Political Participation of Mexican Immigrants in Oregon}

Thank you for agreeing to meet with me today. As you know, I'm Anabel Lopez Salinas, a graduate student at Portland State University. I am working on my dissertation research to find out the nature, density, and operational styles of immigrant participation, leadership selection, and levels of engagement in the metropolitan areas of Salem and Portland, Oregon.

I am especially interested in finding out the patterns of and barriers to civic engagement within your community in the U. S. and how you define civic engagement.

I'd like to ask you several questions, and record your answers - both in my notes and with a recorder. As you know, these records will be stored securely; I won't talk about what you tell me with anyone; and when I write up my study I will not include any details that would identify you. You may stop this conversation at any point, if you wish to.

As we go through the questions in this interview, I would very much appreciate it if you would bring up important points that you realize I have not thought about.

\section{Part I. Basic Demographic Information}

1. Age:

Contact Information:

2. Where were you born?

Is that a city, a town or a village?

3. What's the highest level of education you have achieved?

High School or lower

Undergraduate

Masters, JD, or similar

$\mathrm{PhD}, \mathrm{MD}$, or other doctorate

4. What is your current employment situation?

Student

Employed

Part-time

Full-time

Self-employed

Unemployed

Volunteer

Board member

Entrepreneur

Other:

5. Are you married? 
Divorced, widowed?

6. Do you have children?

What are their ages and sex?

Where were they born?

7. How old were you when you first came to the U.S.?

8. Have you lived here since then, or have you gone back and forth to Mexico?

Please describe

9. Do you speak an indigenous language?

Yes

No

Which one?

10. How would you describe your ability in English?

Speaking: excellent, good, fair or poor

Reading and writing: excellent, good, fair or poor

11. Which language do you use at home?

12. Which language do you use at work?

\section{Part II. Family and relations with Mexico}

13. Do you have family living in Mexico?

Yes Who?

No

14. Did you send money to your family in Mexico last year?

Yes to who?

No

How frequently?

Twice a month Once a month Once every three months

Less than once every three months Once a year

15. Do you know what it used for?

Yes

No

Home expenses

Home construction

Children/siblings' education

Savings

Business

Other 
16. Do you send money to other people that are not your family?

Church School Other

17. In the past year have you participated in any effort to resolve a local/neighborhood problem in Mexico?

No
Yes
problem?

18. How interested are you in Mexican politics and Mexican affairs?

1 Not interested

2 Slightly interested

3 Interested

4 Very Interested

19. Have toy ever voted for the Mexican presidential election either while living in Mexico or after you came to the U.S.?

If your answer is no, why?

20. Have you participated in political activities in Mexico? Supporting a political candidate or political party or have you been nominated for a political position?

21. How do you hear about news from Mexico?

TV

Name
Newspaper
Name
Internet
Facebook
Twitter
Otro
Radio
Name
Friends and family
Other

22. Do you have the intention of going back to Mexico permanently? 
23. Which are the policies that most interest/worry you in Mexico?

\begin{tabular}{|c|c|c|c|c|}
\hline & $\begin{array}{l}\text { Not at all } \\
\text { Important }\end{array}$ & $\begin{array}{l}\text { Somewhat } \\
\text { Important }\end{array}$ & Important & $\begin{array}{l}\text { Very } \\
\text { Important }\end{array}$ \\
\hline a. Drug trafficking & 1 & 2 & 3 & 4 \\
\hline b. Employment & 1 & 2 & 3 & 4 \\
\hline c. Education & 1 & 2 & 3 & 4 \\
\hline d. Health & 1 & 2 & 3 & 4 \\
\hline e. Security & 1 & 2 & 3 & 4 \\
\hline f. Business options & 1 & 2 & 3 & 4 \\
\hline g. Inmigration & 1 & 2 & 3 & 4 \\
\hline h. Other & 1 & 2 & 3 & 4 \\
\hline
\end{tabular}

24. Have you held office in your community of origin?

25. Have you been involved with activities related to HTA's and religious organizations?

Part III. Citizenship and Participation in the Unites States

26. Do you have an idea of what the most prominent issues facing the Latino community are?

27. How interested are you in local community politics and local community affairs in the US?

1 Not interested

2 Slightly interested

3 Interested

4 Very Interested

28. Do you know which organizations in Oregon do more for the wellbeing of the immigrant community?

29. For those who are involved, can you please mention some barriers you think Mexican immigrants face to participate civically in the U.S.?

30. Have you been a volunteer in the United States? If yes, go to the next question, if not go to question \#32.

31. Tell me about your experience as a volunteer in the United States. What do you enjoy the most about being involved with your community of residence?

32. Which factors influenced your lack of involvement with organizations? 
33. Do you think that the best way to obtain a positive change in our community is by working with Latino Organizations?

\section{Community}

34. With which of these groups do you see yourself?

$\begin{array}{lll}\text { Mexicano } & \text { Mixteco } & \text { Zapoteco } \\ \text { Latino } & \text { Otro } & \end{array}$

35. Now, I'd like to ask you some questions about community, i.e. what community means to you. Below you will find a list of places and groups. Please evaluate how strongly you feel they are part of your community.

\begin{tabular}{|l|c|c|c|c|}
\hline & $\begin{array}{c}\text { Not at all } \\
\text { Important }\end{array}$ & $\begin{array}{c}\text { Somewhat } \\
\text { Important }\end{array}$ & Important & $\begin{array}{l}\text { Very } \\
\text { Important }\end{array}$ \\
\hline a. The place I was born. & 1 & 2 & 3 & 4 \\
\hline b. The town where I grew up/was born & 1 & 2 & 3 & 4 \\
\hline c. My ethnic/racial group. & 1 & 2 & 3 & 4 \\
\hline d. My city. & 1 & 2 & 3 & 4 \\
\hline e. The country where I grew up. & 1 & 2 & 3 & 4 \\
\hline f. The country where I live now. & 1 & 2 & 3 & 4 \\
\hline g. My friends. & 1 & 2 & 3 & 4 \\
\hline h. My family. & 1 & 2 & 3 & 4 \\
\hline i. My church/place of worship. & 1 & 2 & 3 & 4 \\
\hline j. The neighborhood where I live now & 1 & 2 & 3 & 4 \\
\hline
\end{tabular}

\section{Political participation}

36. How do you find out about news in the US?

TV

Name

Newspaper

Name

\section{Internet}

Facebook

Twitter

Otro

Radio

Name

Friends and family

Other 
37. Have you voted for any of the presidential elections in the U.S.?

38. Have you supported a political party or candidate in the U.S.?

Yes, from which political party? Can you tell me about your experience?

39. If you could vote, which political party would you vote for? Why?

40. What are the policies that worry/interest you the most in the U.S.?

\begin{tabular}{|c|c|c|c|c|}
\hline & $\begin{array}{c}\text { Not at all } \\
\text { Important }\end{array}$ & $\begin{array}{c}\text { Somewhat } \\
\text { Important }\end{array}$ & Important & $\begin{array}{c}\text { Very } \\
\text { Important }\end{array}$ \\
\hline a. Housing & 1 & 2 & 3 & 4 \\
\hline b. Employment & 1 & 2 & 3 & 4 \\
\hline c. Education & 1 & 2 & 3 & 4 \\
\hline d. Health & 1 & 2 & 3 & 4 \\
\hline e. Security & 1 & 2 & 3 & 4 \\
\hline f. Business opportunities & 1 & 2 & 3 & 4 \\
\hline$\quad$ Green business in Oregon & 1 & 2 & 3 & 4 \\
\hline $\begin{array}{l}\text { Strengthen the relationships } \\
\text { for Mexican business people }\end{array}$ & 1 & 2 & 3 & 4 \\
\hline g. Immigration & 1 & 2 & 3 & 4 \\
$\quad$ in general & 1 & 2 & 3 & 4 \\
$\quad$ undocumented youth & 1 & 2 & 3 & 4 \\
h. Business and economic \\
opportunities & 1 & 2 & 3 & 4 \\
i. Getting driver's licenses & 1 & 2 & 3 & 4 \\
\hline j. Other & & & & 3 \\
\hline
\end{tabular}

41. Are you registered to vote?

No

Yes

42. Please look below at the list of activities that immigrants often participate in. Check the activities that you actually participated in when you were in Mexico (Left Column) and those that you've participated it since arriving in the U.S. (Right Column). 


\begin{tabular}{|c|c|c|c|c|c|c|c|c|c|c|c|c|c|c|c|c|c|c|}
\hline & 密莺 & in & in & in & in & ○ & in & in & in & in & in & in & in & in & in & in & in & in \\
\hline & 蛋 & $\theta$ & $\nabla$ & $\nabla$ & $\nabla$ & $\rightarrow$ & + & + & $\nabla$ & $\nabla$ & + & $\nabla$ & + & 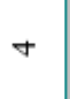 & $\nabla$ & + & $\nabla$ & $\nabla$ \\
\hline & 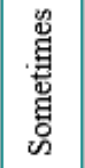 & $m$ & $m$ & $m$ & $m$ & $N$ & $m$ & $m$ & $m$ & $m$ & $m$ & $m$ & $m$ & $m$ & $m$ & $m$ & $m$ & $m$ \\
\hline & 忩 & $N$ & $N$ & $N$ & $N$ & $m$ & $N$ & $N$ & $N$ & $N$ & $N$ & $N$ & $N$ & $N$ & $N$ & $N$ & $N$ & $N$ \\
\hline & Ö & - & $\neg$ & $\rightarrow$ & $\rightarrow$ & + & -1 & - & $\rightarrow$ & $\rightarrow$ & -1 & -1 & - & $\rightarrow$ & $\rightarrow$ & $\rightarrow$ & -1 & $\neg$ \\
\hline $\begin{array}{l}2 \\
\mathbf{S} \\
\Xi \\
\Xi\end{array}$ & 蒂 & 0 & 0 & 0 & 0 & in & 0 & 0 & 0 & 0 & 0 & 0 & 0 & 0 & 0 & 0 & 0 & 0 \\
\hline 疍 & & 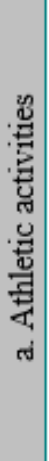 & 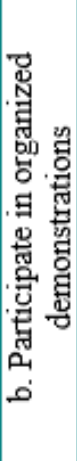 & 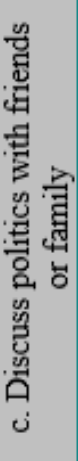 & 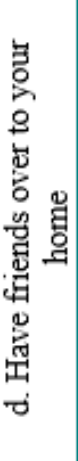 & 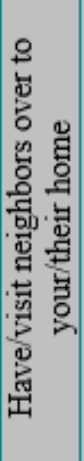 & 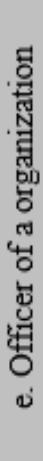 & 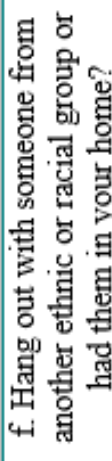 & 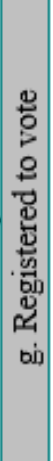 & 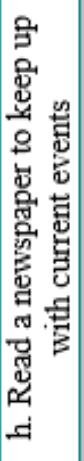 & 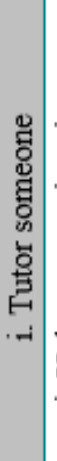 & 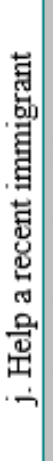 & . & 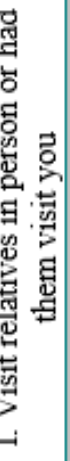 & 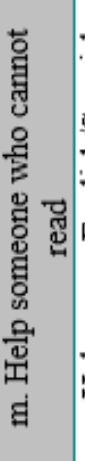 & 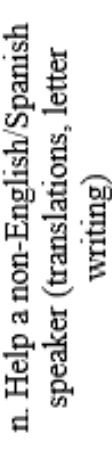 & 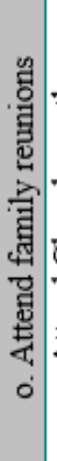 & 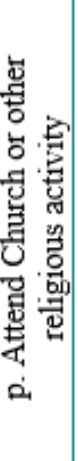 \\
\hline \multirow{6}{*}{ 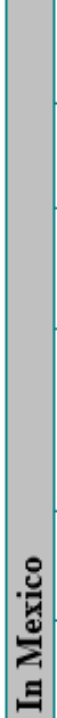 } & 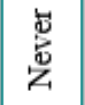 & 0 & 0 & 0 & 0 & 0 & 0 & 0 & 0 & 0 & 0 & 0 & 0 & 0 & 0 & 0 & 0 & 0 \\
\hline & ్ֻ & $\rightarrow$ & - & - & - & - & - & $\rightarrow$ & - & $\neg$ & -1 & $\neg$ & -1 & $\rightarrow$ & $\rightarrow$ & $\rightarrow$ & - & $\neg$ \\
\hline & 离 & $N$ & $N$ & $N$ & $N$ & $N$ & $N$ & $N$ & N & $N$ & $N$ & $N$ & $N$ & $N$ & $N$ & $N$ & $N$ & $N$ \\
\hline & 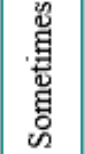 & $m$ & $m$ & $m$ & $m$ & $m$ & $m$ & $m$ & $m$ & $m$ & $m$ & $m$ & $m$ & $m$ & $m$ & $m$ & $m$ & $m$ \\
\hline & 㸃 & $\nabla$ & + & + & $\nabla$ & + & + & $\nabla$ & $\nabla$ & 寸 & $\nabla$ & ナ & + & $\forall$ & $\nabla$ & + & $\nabla$ & + \\
\hline & 密焉 & in & in & in & in & in & in & in & in & in & in & n & in & in & in & in & in & in \\
\hline
\end{tabular}




\begin{tabular}{|c|c|c|c|c|c|c|c|c|c|c|}
\hline in & in & in & in & in & in & in & in & in & in & in \\
\hline$\nabla$ & $\nabla$ & $\nabla$ & ष & 寸 & ナ & $\nabla$ & $\nabla$ & $\nabla$ & $\nabla$ & $\nabla$ \\
\hline$m$ & $m$ & $m$ & $m$ & $m$ & $m$ & $m$ & $m$ & $m$ & $m$ & $m$ \\
\hline N & $\mathrm{N}$ & N & N & N & $\mathrm{N}$ & $\mathrm{N}$ & $\mathrm{N}$ & $\mathrm{N}$ & $\mathrm{N}$ & N \\
\hline$\neg$ & $\neg$ & $\rightarrow$ & - & -1 & $\neg$ & $\neg$ & - & $\neg$ & $\neg$ & -1 \\
\hline 0 & 0 & 0 & 0 & 0 & 0 & 0 & 0 & 0 & 0 & 0 \\
\hline 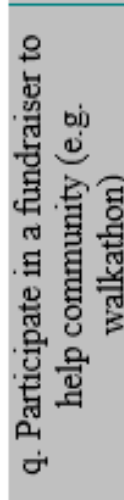 & 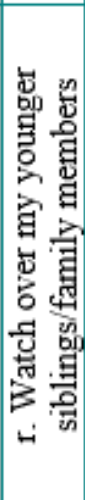 & 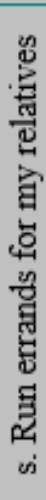 & 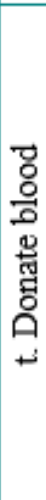 & 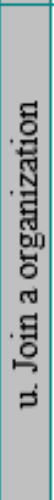 & 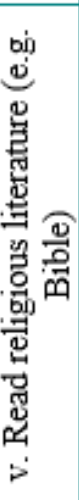 & 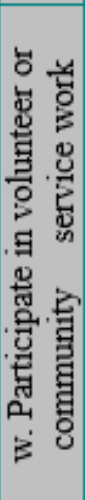 & 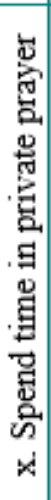 & 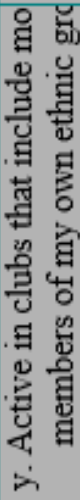 & 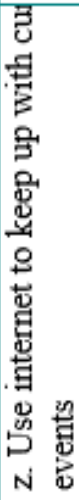 & 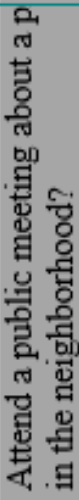 \\
\hline 0 & 0 & 0 & 0 & 0 & 0 & 0 & 0 & 0 & 0 & 0 \\
\hline$\neg$ & $\rightarrow$ & - & - & - & - & $\rightarrow$ & $\neg$ & $\rightarrow$ & - & - \\
\hline N & N & N & N & N & $N$ & $\mathrm{~N}$ & $N$ & N & $N$ & $N$ \\
\hline$m$ & $m$ & $m$ & $m$ & $m$ & $m$ & $m$ & $m$ & $m$ & $m$ & $m$ \\
\hline$\nabla$ & 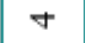 & $\nabla$ & ナ & 寸 & $\forall$ & $\nabla$ & $\nabla$ & $\nabla$ & $\nabla$ & 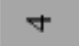 \\
\hline in & in & in & in & in & in & in & in & in & in & in \\
\hline
\end{tabular}


43. Are you a US citizen?

No

Yes (skip to the next)

A. If not, have you applied for citizenship?

No

Yes (skip to the next)

B. If not, are you planning to apply for citizenship?

No

Yes (skip to the next)

C. Are you a legal resident?

No

Yes (skip to the next)

44. Religion

Pentecostal

Presbyterian

Catholic

Other

45. What is your annual income?

Less than 30,000

Between 30,000 - 50,000

Between 50,000 - 80,000

More than 80,000

46. Are you a renter or homeowner?

\section{Thank you very much!!!}




\section{Explorando la Participación Económica, Social y Política de la Población Mexicana Migrante en Oregon}

Gracias por aceptar participar en este estudio. Mi nombre es Anabel López Salinas, estudiante de posgrado de la Universidad Estatal de Portland (PSU). Estoy trabajando con mi tesis de doctorado en la misma universidad con el fin de detectar la naturaleza, densidad y estilos de operación de la participación cívica de los migrantes; así como los niveles de esta participación y liderazgo en el área metropolitana de Salem y Portland, Oregon.

Estoy especialmente interesada en encontrar pautas y barreras de participación cívica en la comunidad donde reside en Estados Unidos; así como el significado de la participación cívica para usted.

Me gustaría hacerle varias preguntas y grabar sus respuestas- en mis notas y en una grabadora. Como usted sabe; estas notas serán resguardadas y no habrá manera de que usted sea identificado. Su participación es completamente confidencial. Usted puede parar esta entrevista cuando así lo desee.

Durante la entrevista me gustaría que usted me dijera si es que hay algún punto que no menciono y que usted considera que es de importancia para la investigación.

\section{Parte I. Información Demográfica}

1. Edad:

Información de Contacto:

2. Lugar de nacimiento: Municipio

Estado

3. Cuál es el grado de educación más alto que ha recibido? (años) (¿Cuántos años fue a la escuela?

¿Dónde? ¿Qué estudio? )

Primaria

Secundaria

Preparatoria

Licenciatura

Maestría/Doctorado

4. ¿Cuál es su situación de empleo actual?

Estudiante

Empleado

Medio tiempo

Tiempo completo

Auto-empleado

Desempleado

Voluntario 
Miembro de mesa directiva

Emprendedor

Ama de casa

Otro:

5. ¿Está casado?

Divorciado/Viudo

Soltero

Unión libre

6. ¿Tiene hijos?

¿De qué edad?

¿Dónde nacieron?

7. ¿Qué edad tenía cuando vino a EU por primera vez? ¿Hace que tiempo llego a los Estados Unidos?

8. ¿Ha vivido aquí desde entonces? O ha ido y venido de México? Por favor describa. Ha vivido en otro estado en los EU? ¿Por cuánto tiempo?

9. ¿Habla algún idioma indígena?

Sí

No ¿Cuál?

10. ¿Cómo describe sus habilidades con el inglés?

Hablado: excelente; bueno o malo

Lectura y escritura: excelente; bueno o malo

11. ¿Qué idioma utiliza en casa?

12. ¿Qué idioma utiliza en el trabajo?

\section{Parte II. Familia y Relaciones con México}

13. ¿Tiene familia viviendo en México? ¿Si? ¿Quien?

No

14. ¿Durante el año pasado, mandó dinero a familiares en México?

$\mathrm{Si}$ ¿a quién?

No

$¿$ Con que frecuencia?

Dos veces al mes __ Una vez al mes___ Una vez cada 3 meses

Menos de una vez cada 3 meses___ Una vez al año 
15. ¿Sabe para qué es utilizado?

Sí

No

Gastos del hogar

Construcción de casa

Educación de los hijos

Ahorro

Negocio

Otro

16. ¿Manda dinero para alguien más que no sea su familia?

Iglesia___ Escuela___ Otro

17. Durante el año pasado, ¿participó en algún esfuerzo por resolver algún problema local o regional en su comunidad de origen?

$\mathrm{Si}$ ¿qué tipo de problema?

No

18. ¿Qué tanto está usted interesado en la política mexicana?

No le interesa

Poco interesado

Interesado

Muy interesado

Describa sus razones:

19. ¿Ha votado alguna vez para elegir al presidente de México? (estando allá y aquí) Si la respuesta es NO, por qué?

20. ¿Ha participado en actividades políticas en México? (apoyado a algún candidato o partido o usted mismo ha sido nominado) A NIVEL DE COMUNIDAD

21. ¿Cómo se entera de noticias relacionadas con México?

Televisión

Nombre de la televisora

Periódico

Nombre del periódico

Internet

Facebook

Twitter

Radio

Nombre de la estación de radio

Amigos

Amigos del trabajo?

Escuela? 
Familiares

Iglesia?

Familia en México

Otro

Hijos nacidos en EU

22. ¿Usted tiene la intención de volver a México permanentemente? Razones

23. ¿Cuáles son las políticas públicas que más le interesan o preocupan en México?

\begin{tabular}{|c|c|c|c|c|c|}
\hline & & No Importante & $\begin{array}{c}\text { Algo } \\
\text { Importante }\end{array}$ & Importante & $\begin{array}{c}\text { Muy } \\
\text { Importante }\end{array}$ \\
\hline & Narcotráfico & 1 & 2 & 3 & 4 \\
\hline & Empleo & 1 & 2 & 3 & 4 \\
\hline & Educacion & 1 & 2 & 3 & 4 \\
\hline & Salud & 1 & 2 & 3 & 4 \\
\hline & Seguridad & 1 & 2 & 3 & 4 \\
\hline & $\begin{array}{l}\text { Opciones de } \\
\text { negocio }\end{array}$ & 1 & 2 & 3 & 4 \\
\hline & Inmigración & 1 & 2 & 3 & 4 \\
\hline & Otro & 1 & 2 & 3 & 4 \\
\hline
\end{tabular}

24. ¿Usted sirvió en algún cargo civil en su comunidad de origen?

$\mathrm{Si}$

¿Cuál?

25. ¿Estuvo o ha estado involucrado en actividades de tequio, HTA's, religiosas o alguna organización que apoye a su comunidad de origen?

$\mathrm{Si}$

No

\section{Parte III. Ciudadanía y Participación en Estados Unidos}

\section{Actividades dentro de la comunidad (Estados Unidos)}

26. ¿Tiene idea de cuál es el problema más serio que actualmente afecta la comunidad migrante y estadounidense donde vive? A NIVEL DE

COMUNIDAD/VECINDARIO

$\mathrm{Si} \_$(pase a la siguiente pregunta)

No 
27. ¿Qué tan interesado está en la situación política/social nacional de Estados Unidos?

1 No interesado

2 Un poco interesado

3 Interesado

4 Muy interesado

28. ¿Sabe, qué organizaciones en Estados Unidos/Oregon son las que hacen más por el bienestar de la población migrante?

29. Para aquellos que no están involucrados. ¿Podría mencionarme los obstáculos que encuentra para involucrarse cívicamente en su comunidad de residencia?

1 No

2 Yes

¿Cuáles son algunos de estos obstáculos?

30. Ha sido voluntario en los Estados Unidos? Si si, pase a la siguiente pregunta, si no pase a la pregunta 32 .

31. Hábleme sobre su experiencia siendo voluntario en los Estados Unidos. ¿Qué es lo que más disfruta de estar involucrado con su comunidad de residencia?

32. Que influyo para que usted esté o no involucrado con cierta organización?

33. Usted piensa que trabajando con estas organizaciones es el mejor camino para lograr un cambio positivo en nuestra comunidad?

\section{COMUNIDAD}

34. ¿En qué grupo se identifica?
Mexicano
Mixteco
Zapoteco

Latino

Otro

35. Ahora, me gustaria hacerle presguntas relacionadas con la comunidad, por ejemplo, que significa comunidad para usted? i.e. Va a encontrar una lista de lugares y grupos, por favor evalue su importancia en su comunidad. 


\begin{tabular}{|l|l|l|c|c|}
\hline & $\begin{array}{l}\text { No } \\
\text { Importante }\end{array}$ & $\begin{array}{l}\text { Algo } \\
\text { Importante }\end{array}$ & Importante & $\begin{array}{l}\text { Muy } \\
\text { Importante }\end{array}$ \\
\hline a. El lugar donde naci & 1 & 2 & 3 & 4 \\
\hline b. El lugar donde nanci/ creci & 1 & 2 & 3 & 4 \\
\hline c. Mi grupo racial & 1 & 2 & 3 & 4 \\
\hline d. Mi ciudad & 1 & 2 & 3 & 4 \\
\hline e. El pais donde creci & 1 & 2 & 3 & 4 \\
\hline f. EL pais donde ahora vivo & 1 & 2 & 3 & 4 \\
\hline g. Mis amigos & 1 & 2 & 3 & 4 \\
\hline h. Mi familia & 1 & 2 & 3 & 4 \\
\hline i. Mi iglesia & 1 & 2 & 3 & 4 \\
\hline j. El vecindario donde vivo. & 1 & 2 & 3 & 4 \\
\hline
\end{tabular}

\section{Participación Política}

36. ¿Cómo se entera de noticias en Estados Unidos?

Televisión

Nombre de la televisora

Periódico

Nombre del periódico

Internet

Facebook

Twitter

Otra red social

Radio

Nombre de la estación de radio

Amigos

Amigos del trabajo?

Escuela?

Iglesia?

Familiares

Familia en México

Familia en Estados Unidos

Hijos nacidos en EU

Otro

37. ¿Ha votado en las elecciones en Estados Unidos con anterioridad?

$1 \mathrm{Si}$

2 No

38. ¿En los años pasados ha trabajado en apoyo (voluntario o no) a algún partido político o candidato en los EU? A NIVEL DE COMUNIDAD/VECINDARIO 
$1 \mathrm{Si}$ ¿Qué partido? ¿Podría hablarme sobre esa experiencia?

2 No

39. En caso de que pudiera votar, ¿Por cuál partido político (Estados Unidos) inclinaría su voto?

¿Por qué?

40. ¿Cuáles son las políticas públicas que más le interesan o preocupan en EU?

\begin{tabular}{|c|c|c|c|c|}
\hline & $\begin{array}{c}\text { No } \\
\text { Importante }\end{array}$ & $\begin{array}{c}\text { Algo } \\
\text { Importante }\end{array}$ & Importante & $\begin{array}{c}\text { Muy } \\
\text { Importante }\end{array}$ \\
\hline a. Vivienda & 1 & 2 & 3 & 4 \\
\hline b. Empleo & 1 & 2 & 3 & 4 \\
\hline c. Educacion & 1 & 2 & 3 & 4 \\
\hline d. Salud & 1 & 2 & 3 & 4 \\
\hline e. Seguridad & 1 & 2 & 3 & 4 \\
\hline f. Opciones de negocio & 1 & 2 & 3 & 4 \\
\hline $\begin{array}{l}\text { Nicho en la economía verde } \\
\text { de Oregon }\end{array}$ & 1 & 2 & 3 & 4 \\
\hline $\begin{array}{l}\text { Fortalecer la inversión de } \\
\text { empresarios } \\
\text { Mexicanos }\end{array}$ & 1 & 2 & 3 & 4 \\
\hline g. Inmigración & 1 & 2 & 3 & 4 \\
\hline En general & 1 & 2 & 3 & 4 \\
\hline Jóvenes sin documentados & 1 & 2 & 3 & 4 \\
\hline h. Nicho en la economía & 1 & 2 & 3 & 4 \\
\hline $\begin{array}{l}\text { i. Abogar por licencias de } \\
\text { manejo }\end{array}$ & 1 & 2 & 3 & 4 \\
\hline j. Otro & 1 & 2 & 3 & 4 \\
\hline
\end{tabular}

41. ¿Está registrado para votar? $\mathrm{Si}$

No

42. Por favor vea la siguiente lista de posibles actividades en las que los migrantes participan. Hagame saber la frencuencia en la que usted realizo dichad actividades cuando estaba en Mexico y desde que usted llego a los Estados Unidos. 


\begin{tabular}{|c|c|c|c|c|c|c|c|c|c|c|c|c|c|c|c|c|c|}
\hline & 晃兽 & in & in & in & in & 0 & in & in & in & in & in & in & in & in & in & in & in \\
\hline \multirow{5}{*}{ 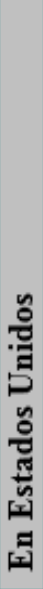 } & 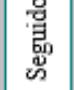 & $\nabla$ & 寸 & $\nabla$ & $\nabla$ & $\neg$ & $\nabla$ & $\nabla$ & $\nabla$ & 寸 & $\nabla$ & 寸 & 寸 & $\nabla$ & $\nabla$ & $\nabla$ & $\nabla$ \\
\hline & 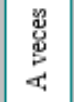 & $m$ & $m$ & $m$ & $m$ & $\sim$ & $m$ & $m$ & $m$ & $m$ & $m$ & $m$ & $m$ & $m$ & $m$ & $m$ & $m$ \\
\hline & 岁 & $N$ & N & $N$ & $\sim$ & $m$ & $\sim$ & $\sim$ & N & $\sim$ & $N$ & $\sim$ & N & $N$ & N & $N$ & N \\
\hline & $-\stackrel{N}{0}$ & $\neg$ & $\rightarrow$ & $\neg$ & $\rightarrow$ & $\nabla$ & $\rightarrow$ & $\neg$ & -7 & $\rightarrow$ & $\neg$ & $\neg$ & $\rightarrow$ & $\neg$ & $\neg$ & $\rightarrow$ & $\rightarrow$ \\
\hline & 㮩 & 0 & 0 & 0 & 0 & in & 0 & 0 & 0 & 0 & 0 & 0 & 0 & 0 & 0 & 0 & 0 \\
\hline \multicolumn{2}{|c|}{ 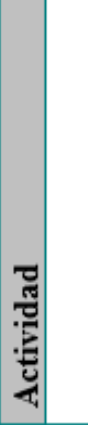 } & 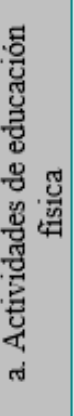 & 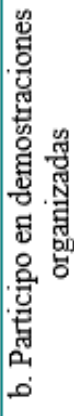 & 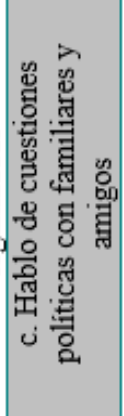 & 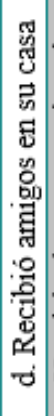 & 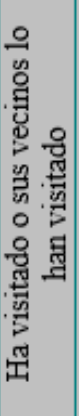 & 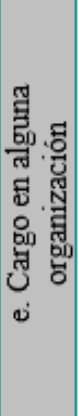 & 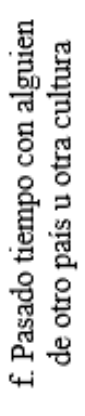 & 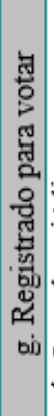 & 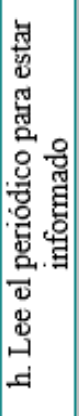 & 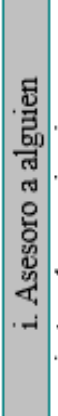 & 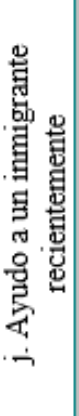 & 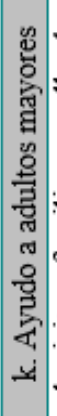 & 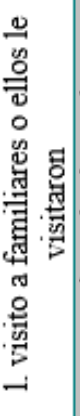 & 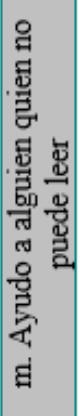 & 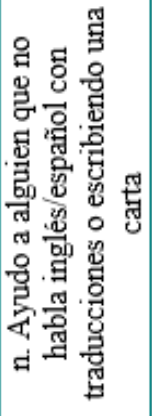 & 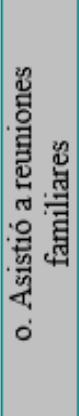 \\
\hline \multirow{6}{*}{ 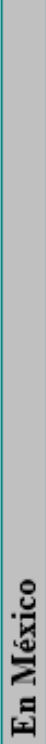 } & 息 & 0 & 0 & 0 & 0 & 0 & 0 & 0 & 0 & 0 & 0 & 0 & 0 & 0 & 0 & 0 & 0 \\
\hline & $\stackrel{\mathbb{2}}{\stackrel{2}{2}}$ & - & - & $\rightarrow$ & -1 & $\rightarrow$ & $\neg$ & $\rightarrow$ & -1 & $\rightarrow$ & -1 & $\rightarrow$ & -1 & 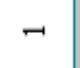 & $\rightarrow$ & $\rightarrow$ & $\rightarrow$ \\
\hline & 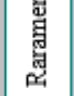 & $N$ & $\sim$ & $N$ & N & $\sim$ & $\sim$ & $\sim$ & $N$ & $\sim$ & N & $\sim$ & $N$ & $N$ & N & $\sim$ & $N$ \\
\hline & 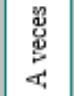 & $m$ & $m$ & $m$ & $m$ & $m$ & $m$ & $m$ & $m$ & $m$ & $m$ & $m$ & $m$ & $m$ & $m$ & $m$ & $m$ \\
\hline & 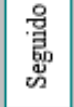 & $\nabla$ & $\forall$ & $\forall$ & 寸 & $\nabla$ & $\nabla$ & $\forall$ & + & 寸 & $\nabla$ & $\forall$ & $\nabla$ & $\forall$ & $\nabla$ & 寸 & $\nabla$ \\
\hline & 家亮 & in & in & in & n & in & in & in & in & $n$ & in & n & in & in & $n$ & $n$ & m \\
\hline
\end{tabular}




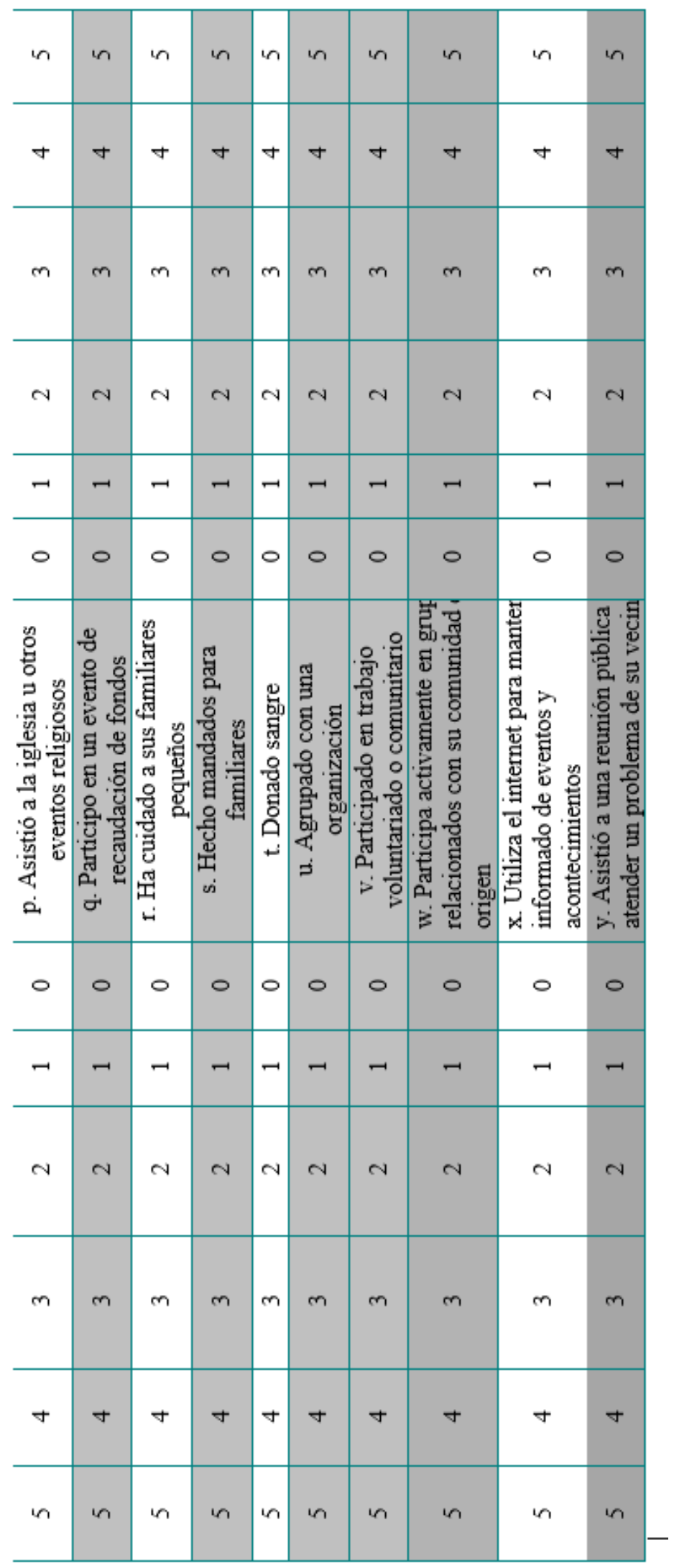


43. ¿Es usted ciudadano estadounidense?

$\mathrm{Si}$

No

A. ¿Ha aplicado para la ciudadanía?

$\mathrm{Si}$

No

B. Si su respuesta es no. Ha pensado/piensa en aplicar para la ciudadanía?

$\mathrm{Si}$

No

C. ¿Es usted residente legal?

$\mathrm{Si}$

No

44. Religión

Pentecostal

Presbiteriano

Católico

Otro

45. ¿Cuál es su ingreso anual?

Menos de 30,000

Entre 30,000 - 50,000

Entre 50,000 - 80,000

Más de 80,000

46. ¿Usted renta o es dueño de su vivienda?

Dueño de casa

Renta

\section{Muchas gracias por su participación}


Appendix D. Gift Card Receipts (English and Spanish) 


\section{Portland State University \\ Exploring Economic, Social and Political Participation of Mexican Immigrants in Oregon \\ Anabel Lopez Salinas}

\section{GIFT CARD RECEIPT}

My signature on this receipt signifies that I received a $\$ 10$ gift card for my participation in an interview conducted by Anabel Lopez Salinas, a graduate student at the Hatfield School of Government at Portland state University.

Printed Name

Signature

Date

\section{Portland State University}

Explorando la Participación Económica, Social y Política de los Migrantes Mexicanos en Oregon

Anabel López Salinas

\section{RECIBO DE LA TARJETA DE REGALO}

Mi firma en este recibo indica que recibí una tarjeta de regalo por valor de $\$ 10$ por mi participación en una entrevista realizada por Anabel López Salinas, estudiante de posgrado en la Escuela de Gobierno de la Universidad Estatal de Portland.

Nombre

Firma

Fecha 